\title{
Performance and Market Evaluation of the Bladeless Turbine
}

\author{
B. A. Garrett-Price \\ I. S. Barnhart \\ E. J. Eschbach
}

October 1982

Prepared for the U.S. Department of Energy under Contract DE-AC06-76RLO 1830

Pacific Northwest Laboratory Operated for the U.S. Department of Energy by Battelle Memorial Institute 


\title{
DISCLAIMER
}

This report was prepared as an account of work sponsored by an agency of the United States Government. Neither the United States Government nor any agency thereof, nor any of their employees, makes any warranty, express or implied, or assumes any legal liability or responsibility for the accuracy, completeness, or usefuiness of any information, apparatus, product, or process disclosed, or represents that its use would not infringe privately owned rights. Reference herein to any specific commercial product, process, or service by trade name, trademark, manufacturer, or otherwise, does not necessarily constitute or imply its endorsement, recommendation, or favoring by the United States Government or any agency thereof. The views and opinions of authors expressed herein do not necessarily state or reflect those of the United States Government or any agency thereof.

\author{
PACIFIC NORTHWEST LABORATORY \\ operated by \\ BATTELLE \\ for the \\ UNITED STATES DEPARTMENT OF ENERGY \\ under Contraci DE-AC06-76RLO 1830
}

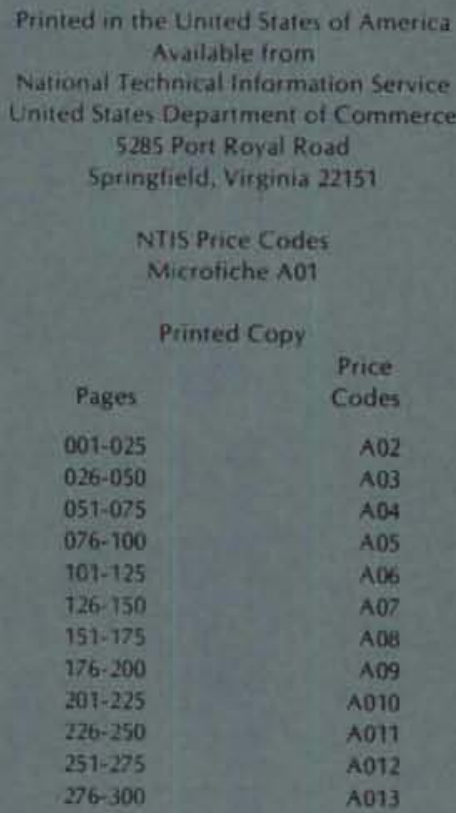


PERFORMANCE AND MARKET EVALUATION OF THE BLADELESS TURBINE

B. A. Garrett-Price

J. S. Barnhart

E. J. Eschbach

October 1982

Prepared for the U.S. Department of Energy under Contract DE-AC06-76RLO 1830

Pacific Northwest Laboratory Richland, Washington 99352 



\subsection{SUMMARY}

This section summarizes the results of the technical and market evaluation of the Gamell bladeless turbine.

The three-inch diameter prototype turbine was tested with air over a range of inlet pressures from 20 to 100 psia and speeds of $10,20,30$ and 40 thous and rpm. The peak efficiency of 22.5 percent was recorded at a pressure of 98 psia and a speed of 40,000 rpm. Efficiency increased slightly with speed and inlet pressure over the range of test conditions.

The test program was somewhat hindered by mechanical failures. The turbine bearings in particular were unreliable, with two instances of outright failure and numerous cases of erratic performance. The test apparatus, methodology and results are described in detail in Section 3.0.

A model of the bladeless turbine was developed to aid in interpreting the experimental results. A macroscopic approach, incorporating several favorable assumptions, was taken to place a reasonable upper bound on turbine efficiency. The model analytically examines the flow through the air inlet nozzles and the interaction between the fluid jet and the turbine blades. The analysis indicates that the maximum possible efficiency of a tangential flow turbine with straight axial blades is 50 percent. This is a direct consequence of turning the fluid only 90 degrees relative to the turbine blade. Performance modeling and prediction are discussed in detail in Section 4.0 .

The adoption of the bladeless turbine as the expander in an Organic Rankine Cycle (ORC) will depend to a great extent on the efficiency of the turbine. The market potential for ORC technology will also impact the adoption of the bladeless turbine. Other expanders have demonstrated efficiencies of 60 to $80 \%$ in ORC systems. The Gamell turbine had a peak test efficiency of $22.5 \%$ and a maximum theoretical efficiency of $50 \%$. Costs of the turbine are highly uncertain, relying to a great extent on cost reductions achieved through quantity production and through learning. The market analysis is discussed in more detail in Section 5.0 . 


\section{CONTENTS}

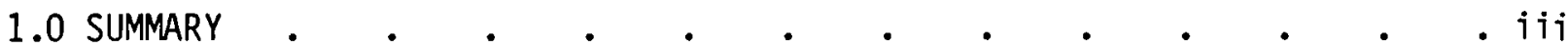

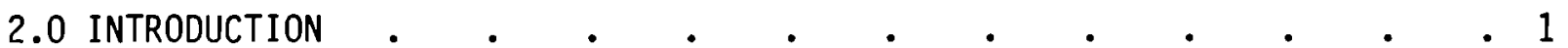

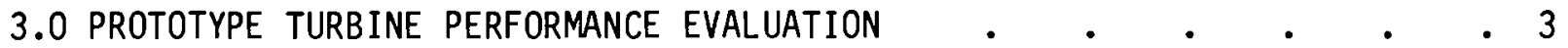

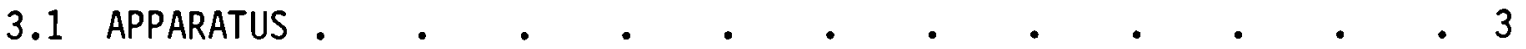

3.1.1 Prototype Gamell Turbine . • • • . . . 3

3.1.2 Test Stand and Air Supply Network . . . . . . . 6

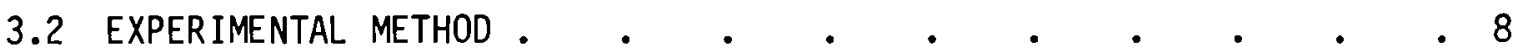

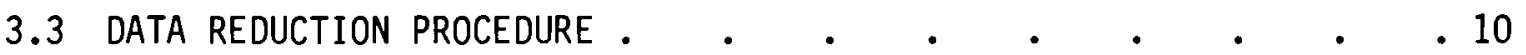

3.3.1 Torque Output • . . . . . . . . . . . 11

3.3.2 Rotational Speed . . . . . . . . . . . 11

3.3.3 Mass Flow Rate . . . . . . . . . . . . 11

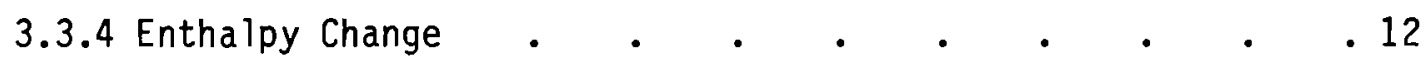

3.4 EXPERIMENTAL RESULTS AND DISCUSSION $\quad . \quad \ldots \quad . \quad . \quad . \quad . \quad . \quad 13$

3.4.1 Summary of Testing Program . . . . . . . . 13

3.4.2 Configuration E Test Results . • . • • . . • . . 16

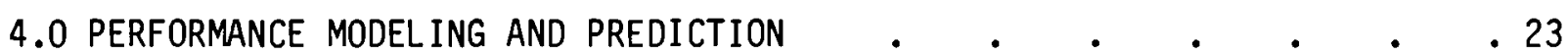

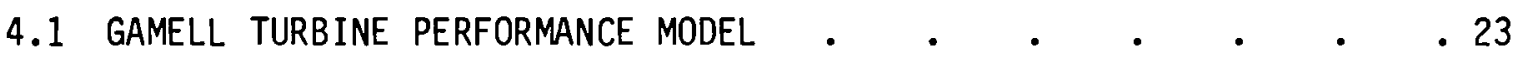

4.1.1 Air Inlet Nozzle Flow . . . . . . . . . . 23

4.1.2 Air Jet-Turbine Blade Interaction . . . . . . . 25

4.1.3 Turbine Loss Mechanisms . . . . . . . . . . 29

4.1.4 Comparison Between Model and Experiment . . . . 32

4.2 TURBOMACHINERY SCALING RELATIONSHIPS . • • • • • • . . 33

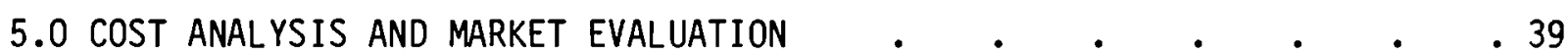

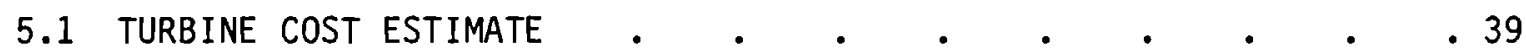

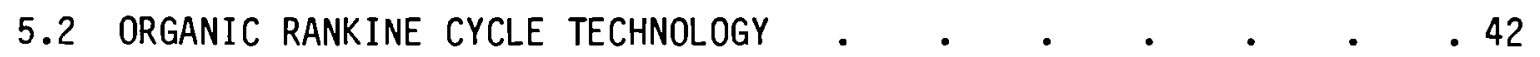

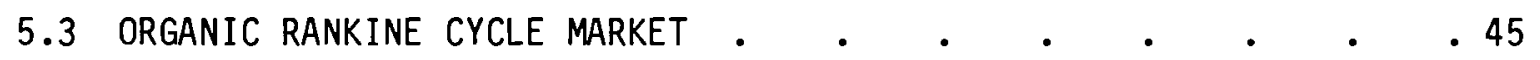

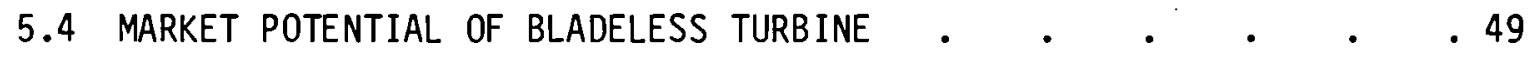

REFERENCES $. \quad . \quad . \quad . \quad . \quad . \quad . \quad . \quad . \quad . \quad . \quad . \quad .53$

APPENDIX A - ROTAMETER CALIBRATION $\quad$ •

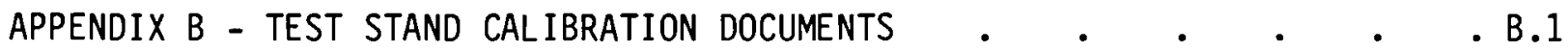

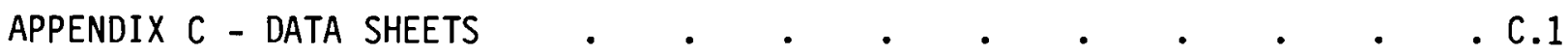

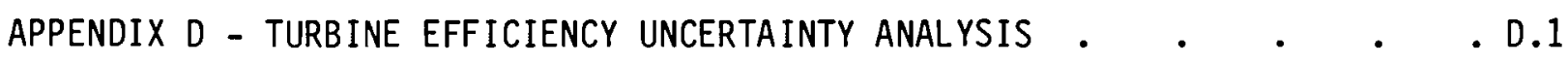




\section{FIGURES}

3.1 Exploded View of Prototype Gamell Turbine . . . . . . 4

3.2 Knurled Turbine Rotor . . . . . . . . . . . 5

3.3 Exploded View of Turbine Test Stand . . . . . . . 8

3.4 Turbine Efficiency Versus Inlet Pressure at 10,000 RPM . . . 17

3.5 Turbine Efficiency Versus Inlet Pressure at 20,000 RPM . . . 18

3.6 Turbine Efficiency Versus Inlet Pressure at 30,000 RPM . . 19

3.7 Turbine Efficiency Versus Inlet Pressure at 40,000 RPM . . . 20

4.1 Gamell Turbine Air Inlet Nozzle and Three Alternative Models . $\quad 24$

4.2 Air Jet and Turbine Blade Geometry with Velocity Polygons . . 25

4.3 Turbine Efficiency versus Velocity Ratio . . . . . . . 30

4.4 Effect of Tip Clearance on Turbine Efficiency . . . . . . 31

4.5 Turbine Model and Peak Experimental Efficiencies . . . . 33

4.6 Turbine Performance Versus Diameter . . . . . . . . . 37

4.7 Output Power with Organic Working Fluid . . . . . . 38

5.1 Turbine Cost as a Function of Rotor Diameter . . . . . . 41

5.2 Rankine Cycle Flowchart . . . . . . . . . 42

5.3 Rankine Cycle Temperature-Enthalpy Diagram . . . . . . . 43

5.4 Theoretical Rankine Cycle Efficiency as a Function
of Temperature . . . . . . 44

5.5 ORC System Costs . $\quad . \quad . \quad . \quad . \quad . \quad . \quad . \quad . \quad . \quad .47$

5.6 Rankine Cycle Turbocharging System . . . . . . . . 51

5.7 Heat Recovery to Supercharge Air Compressor . . . . . 52

\section{$\underline{\text { TABLES }}$}

3.1 Gamell Turbine Prototype Dimensions . . . . . . . 6

3.2 Turbine Configurations Tested . . . . . . . . . 13

3.3 Chronology of Prototype Testing . . . . . . . . . 15

5.1 Turbine Machine Time and Cost . . . . . . . . . 40

5.2 Organic Rankine Cycle Demonstration Projects . . . . . 46

5.3 Barriers to ORC Market Penetration . . . . . . . 48 


\subsection{INTRODUCTION}

The Game 11 turbine is a proprietary bladeless device that is essentially a knurled wheel inside a multi-port housing. The turbine operates on a combined "drag" and "impulse" principle. A portion of the energy of the working fluid is imparted to the rotor through the action of shear forces on the periphery of the rotor. A part of the kinetic energy of the fluid is transferred, via impulse, to the turbine rotor. That is, the Gamell turbine uses both the frictional forces (drag) of the working fluid and the velocity head (impulse) to transfer energy from the working fluid to the turbine rotor.

The prototype turbine, with an attached 1000:1, four-stage reduction gear train, was previously tested by Gardner-Denver for the Franklin Research Center (FRC). Using air as the working fluid, the output torque, speed, and volumetric air flow rate were measured over a range of inlet pressures. The peak efficiency of the turbine with gear box attached was found to be $17.5 \%$. Since the reducing gear was not tested by itself, data from gear manufacturers were used by FRC to estimate an efficiency of $27 \%$ for the reduction gear. This led to an estimated peak efficiency for the prototype Game 11 turbine of $64.5 \%$ at an inlet pressure of 50 psig.

In their analysis, FRC indicated that the turbine has potential feasible application in the following areas: low-head hydroelectric power generation, solar-powered irrigation, air-powered generator for coal mining operations, and vehicle propulsion.

Pacific Northwest Laboratory (PNL) was contracted by the Department of Energy, Office of Industrial Programs to assess the potential of the Gamell turbine to compete with other commercial or prototype turbines. Objectives of the program included obtaining performance test data for the turbine without reduction gear attached to eliminate the uncertainty involved in estimating the gear box efficiency. The program was also intended to assess the technical and market potential of the turbine for specific applications selected from a list of candidate applications provided by the turbine proponent.

The purpose of this report is to present the results of PNL's analysis of the potential of the Gamell turbine in waste energy utilization applications. 
Both the technical performance of the turbine, as determined through experimental tests and the expected market performance are discussed. The market analysis is focused on two specific applications: waste energy utilization from an internal combustion engine to supercharge a 200 horsepower air compressor and waste energy recovery from the exhaust of an internal combustion engine to turbocharge the engine itself. In both cases, the Gamell turbine acts as an expander in an organic Rankine cycle. 


\subsection{PROTOTYPE TURBINE PERFORMANCE EVALUATION}

A three-inch diameter prototype Gamell turbine was evaluated experimentally by Pacific Northwest Laboratory (PNL) using air as the working fluid. Data were recorded at rotational speeds of $10,20,30$ and 40 thousand rpm; a rotational speed of 62,000 rpm was achieved with no load on the turbine. Inlet pressures ranged from 20 to $100 \mathrm{psia}$. The turbine exhausted to atmosphere. Rotational speeds were measured with a non-contact optical sensor. The torque produced by the turbine was measured with a cradle dynamometer bearing upon a precision load cell. A tangential flow air brake, coaxial with the turbine, absorbed the power transmitted. The object of the tests was to determine the turbine efficiency as a function of rotational speed and load. This section includes a description of the prototype Gamell turbine and the test stand used to evaluate it. The experimental method and data reduction procedures are described. Experimental results in the form of turbine efficiency versus inlet pressure at four rotational speeds are presented and discussed.

\subsection{APPARATUS}

The equipment used in this evaluation consisted of the prototype Gamell turbine and a test stand and air supply network designed and built specifically for this experiment. The prototype was supplied by Joseph Gamell Industries, Inc. and was modified only as required to facilitate testing. The test stand design was complicated by the exceedingly high rotational speeds and low torques characteristic of the Gamell turbine. A thorough search failed to reveal any device that could simultaneously load the turbine and quantify the torque (or power) being transmitted; thus, the torque output was measured indirectly with a cradle dynamometer. A non-contact optical sensor provided reliable readings of the rotational speed. This section includes descriptions of the prototype Gamell turbine, turbine test stand, air supply network, and all peripheral devices required to perform the evaluation.

\subsubsection{Prototype Gamell Turbine}

An exploded view of the aluminum prototype tested by PNL is presented in Figure 3.1. A photograph of the turbine rotor is shown in Figure 3.2. 


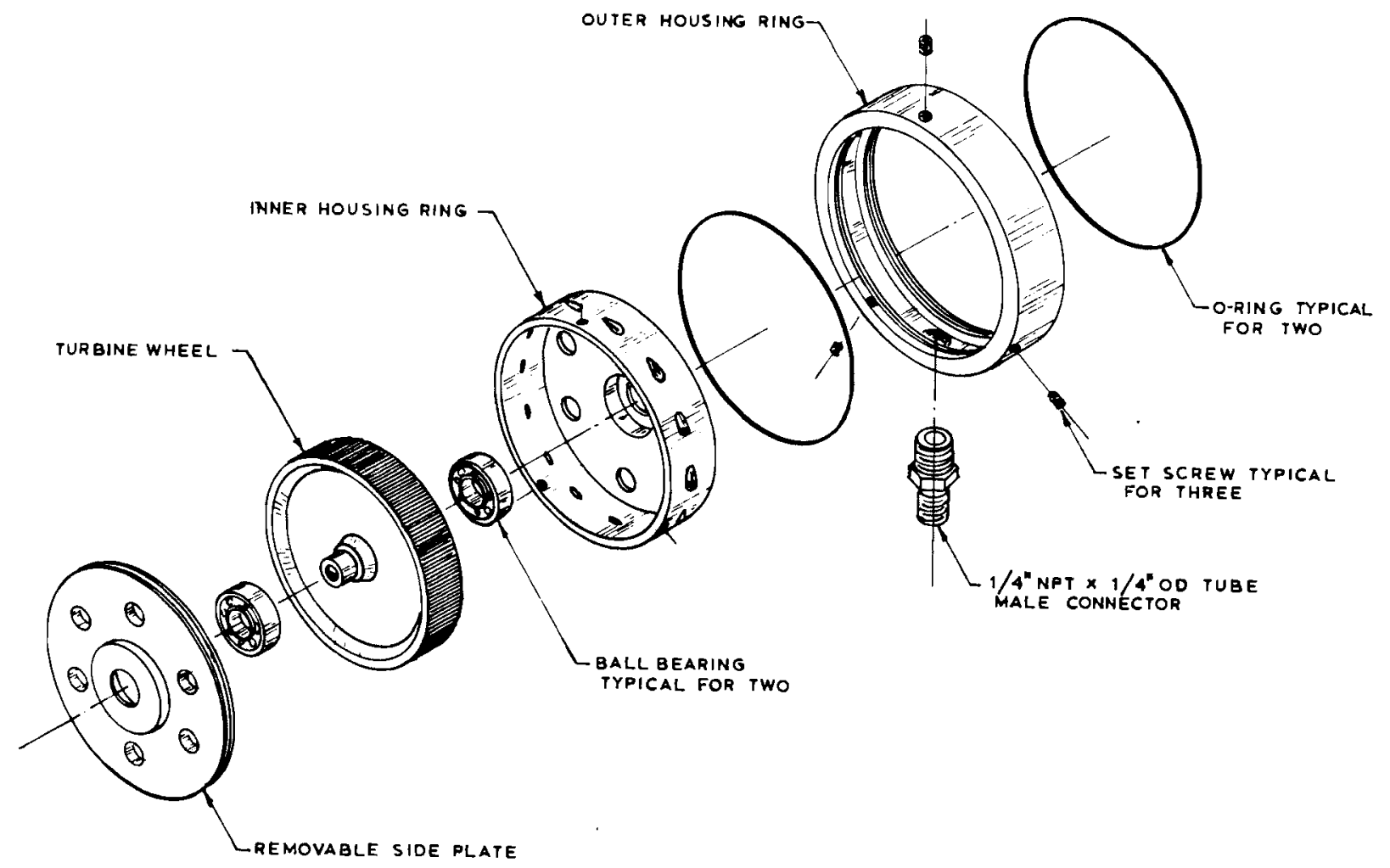

FIGURE 3.1. Exploded View of Prototype Gamell Turbine

Significant dimensions are listed in Table 3.1. The Gamell turbine is a tangential flow turbomachine consisting of a double-ring housing and a toothed wheel. Flow enters through a radial port in the outer housing ring and is distributed throughout an annular plenum bounded by the outer and inner housing rings. $0-$ rings hold the two housing rings together. Flow passes from the plenum through twelve equally-spaced nozzles machined into the inner housing ring. The nozzles are oriented tangent to a circle of 2.88-inch diameter, slightly less than that of the turbine wheel (2.98 inches). The 185 blades on the turbine whee 1 are straight and parallel to the turbine axis; thus, the fluid jets leaving the nozzles strike the blades at an incidence angle of 90 degrees. The flow is turned axially and radially outward, transferring momentum to the turbine wheel via impulse and drag as the fluid passes over the knurled blades. To reach the six exit ports on each side of the casing, the flow turns radially inward and passes through an axial gap between the turbine wheel and side plate. 


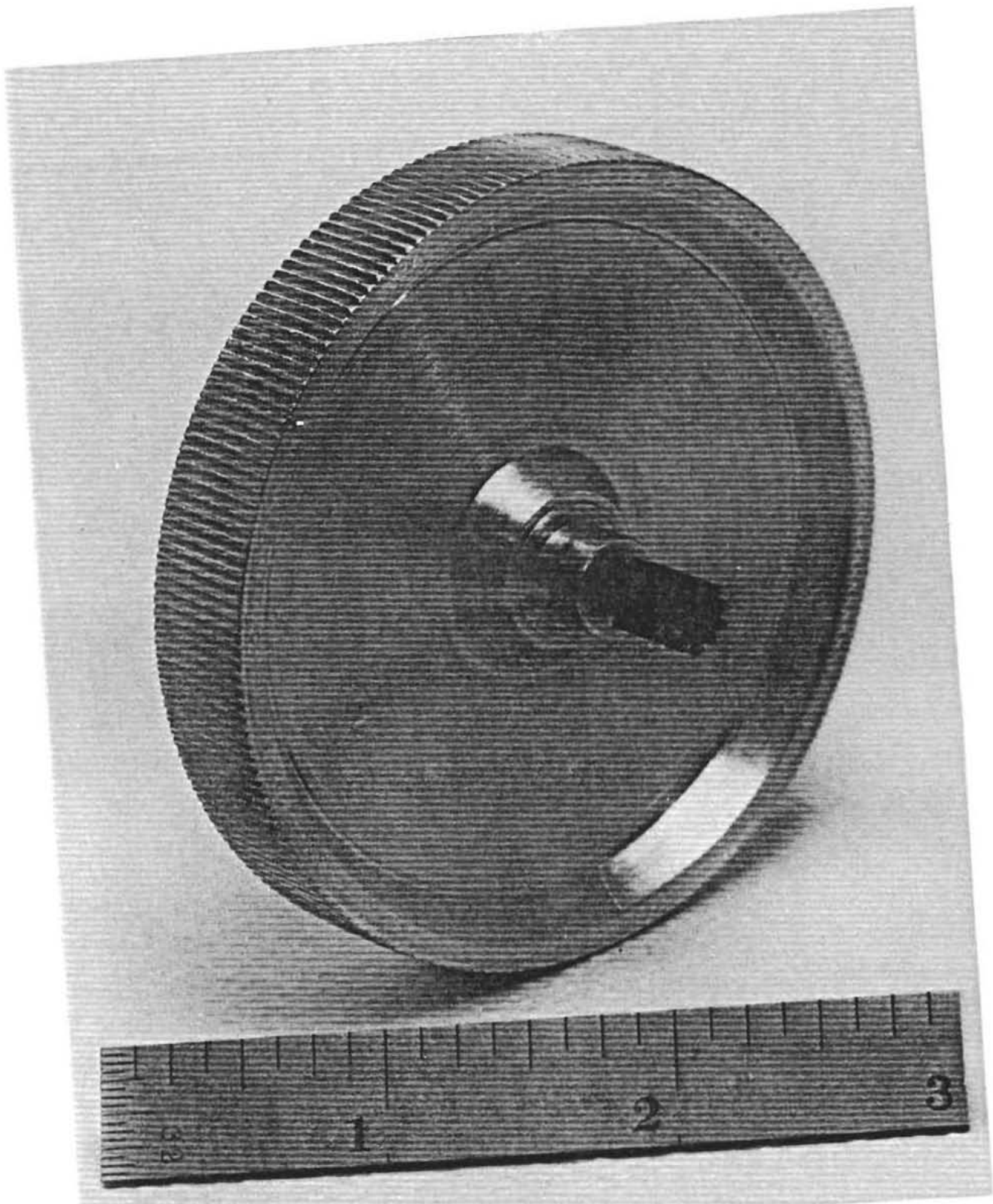

FIGURE 3.2. Knurled Turbine Rotor 
TABLE 3.1. Game11 Turbine Prototype Dimensions

$\begin{array}{ll}\text { Housing Outer Ring Outside Diameter, in. } & 3.750 \\ \text { Housing Inner Ring Outside Diameter, in. } & 3.250 \\ \text { Air Inlet Plenum Height, in. } & 0.105 \\ \text { Air Inlet Plenum Width, in. } & 0.382 \\ \text { Housing Inner Ring Inside Diameter, in. } & 3.000 \\ \text { Number of Air Inlet Nozzles } & 12 \\ \text { Inlet Nozzle Throat Diameter, in. } & 0.046 \\ \text { Nozzle Tangent Circle Diameter, in. } & 2.880 \\ \text { Turbine Wheel Major Diameter, in. } & 2.984 \\ \text { Number of Blades } & 185 \\ \text { Blade Height, in. } & 0.015 \\ \text { Tip Clearance, in. } & 0.008 \\ \text { Blade Width, in. } & 0.503 \\ \text { Housing Width, in. } & 0.575 \\ \text { Turbine Wheel Axial Clearance, in. } & 0.036 \\ \text { Number of Exit Ports Per Side } & 6 \\ \text { Exit Port Diameter, in. } & 0.312 \\ \text { Exit Port Circle Diameter, in. } & 2.530\end{array}$

The turbine was delivered to PNL with Miniature Precision Bearing Company SR6 enclosed-raceway ball bearings. Because the age and condition of these bearings were unknown, PNL purchased open-raceway bearings from the same manufacturer. The open-raceway bearings reportedly run cooler and with less drag than closed-raceway bearings. Both types of bearings were used during testing.

\subsubsection{Test Stand and Air Supply Network}

The Gamell turbine prototype was tested in PNL's Engineering Development Laboratory in Richland, Washington. The air supply network and test stand were designed and built specifically for this task. Clean, dry, oil-free compressed air at 100 psig was provided by the laboratory air system. The air supply network supplied both the turbine and the air brake against which it was driven. Carbon steel 1/2-inch pipe was used for most of the air system. Reinforced Tygon tubing of 1/4-inch inside diameter and 1/32-inch wall thickness was used to connect the piping to the turbine and air brake housings. Air flow to the brake was unmetered and was controlled with a brass globe valve.

Air flow to the turbine was measured with two Schutte \& Koerting Safeguard high-pressure rotameters. The calibration of these rotameters performed by PNL is presented in Appendix A. Brass globe valves were used to control flow. The air temperature at the rotameters and at the turbine inlet was measured with 
Type $\mathrm{J}$ thermocouples connected to a Fluke model 2166A Digital Thermometer. These instruments and all others used in the turbine testing were calibrated traceable to National Bureau of Standards references; copies of the appropriate calibaration documents are included in Appendix $B$.

Two instruments were used to measure the air pressure at the rotameters and turbine inlet. During the early testing, a Validyne P305D pressure transJucer was used; however, the transducer failed when water (used for leak testing) penetrated a seal enclosing electronic circuits. A digital-readout Heise pressure gage was used for subsequent tests. Excitation for the Validyne transducer was by a Power Design Inc. direct current power supply. A Keithley 191 digital multimeter displayed the transducer output.

The test stand, shown in an exploded view in Figure 3.3, was designed to provide simultaneous rotational speed and torque measurements as the turbine operated under load. Rotational speeds were measured with a Pioneer phototachometer, a non-contact optical device. The torque output was measured with a cradle dynamometer, a device widely used in turbomachinery evaluations. $(2,3)$ With the turbine operating under load, the housing experiences a torque equal in magnitude and opposite in direction to that transmitted by the shaft. The housing is "cradled" in bearings so that the torque is transmitted via a moment arm to a load cell or similar device.

The test stand, like the turbine, was fabricated largely of aluminum. The turbine housing was supported by two ball bearings which, in turn, were seated in 3/4-in. thick side plates. A clamp with an integral moment arm transmitted the housing torque to an Interface Minibeam MB-5-4 load cell. Excitation for the load cell was supplied by a Power Design Inc. direct current power supply. The load cell output and excitation voltage were displayed on the same Keithley digital multimeter used with the pressure transducer.

The turbine power output was transmitted to the air brake via a stainless steel shaft. The load on the turbine was controlled by varying the air flow to the brake. The original test stand design included a third shaft bearing on the outboard end of the air brake; however, vibration caused the 3-axis linear translation stage used to position the bearing to wander aimlessly, making the bearing ineffectual. 


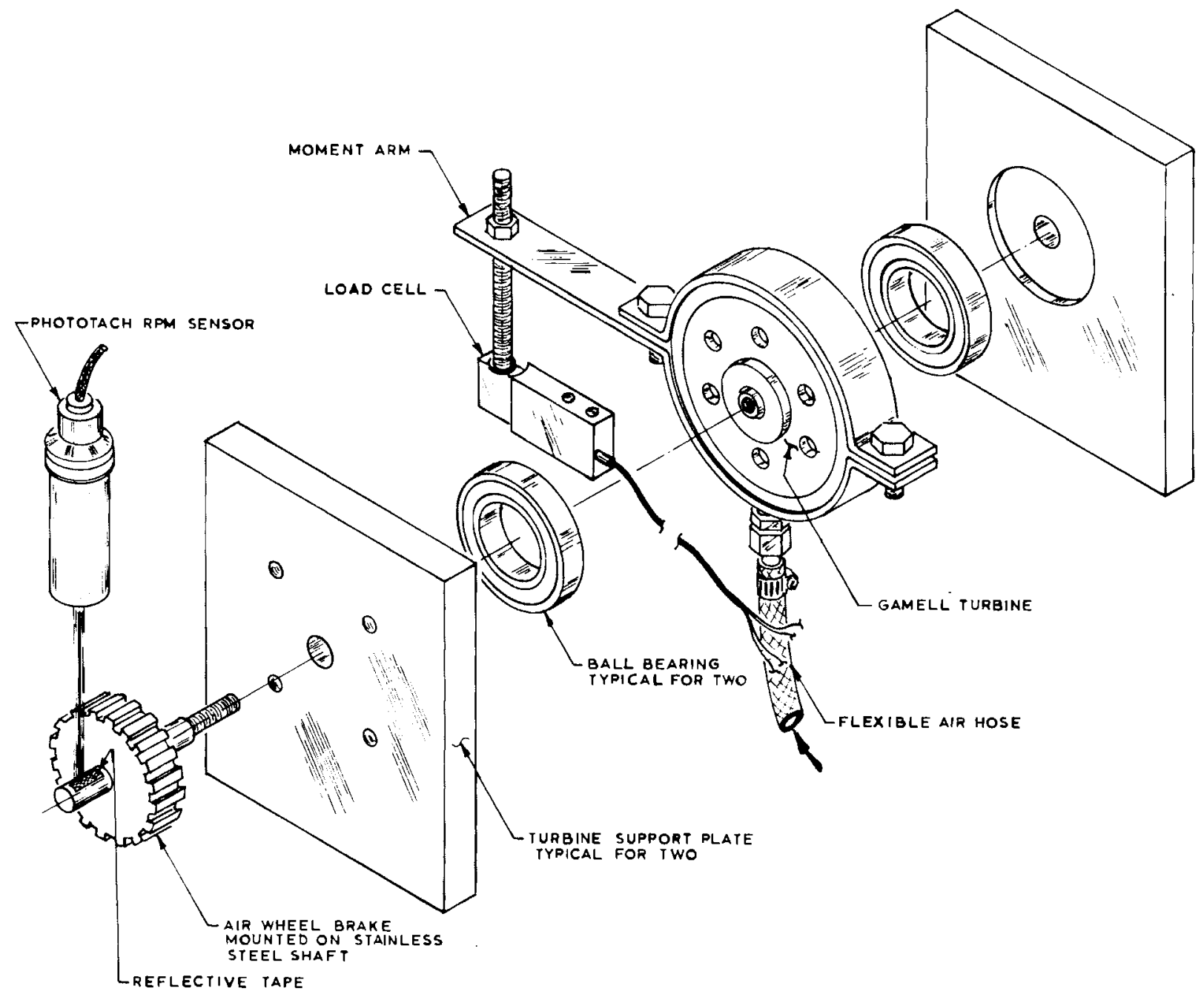

FIGURE 3.3. Exploded View of Turbine Test Stand

A $0.375-i n$. thick Lexan safety shield was used during testing to prevent injury in the event of catastrophic failure.

\subsection{EXPERIMENTAL METHOD}

The object of the test program was to evaluate turbine efficiency at a variety of loads and rotational speeds. These two parameters could be varied independently by balancing the air flows to the turbine and brake. Turbine load was indicated by the inlet pressure. Rotational speed was monitored directly by the photo-tachometer. Each data point required about 15 seconds 
to record once the valves had been properly adjusted. Two individuals were present at all times during testing.

Several activities were completed before rolling the turbine. Excitation voltages for the load cell and pressure transducer were set. The atmospheric pressure was noted. The zero reading on the Heise pressure gage, which varied by about $0.7 \mathrm{psi}$, was recorded. The load cell reading with the turbine stationary (the static zero load cell reading) was recorded. The system was pressurized. A noise-reduction housing and the Lexan safety shield were set in place. The investigators donned protective goggles and headphones.

The turbine was rolled by opening the throttling valve slowly, causing a gradual acceleration to the desired speed (usually 10,000 rpm). Flow to the air brake was not initiated immediately; at this stage, the only load on the turbine was the brake windage loss. The turbine air flow was adjusted until the desired rotational speed was achieved. This was often a time consuming process for the following reasons: 1) the significant inertia of the rotating element slowed its response to air flow changes, 2) the air supply pressure varied because of compressor cycling, and 3) erratic bearing performance sometimes resulted in abrupt speed fluctuations. With the turbine rotating at the desired speed, a "no-load" (no air flow to the brake) data set was recorded. To best approximate steady-state conditions, the most rapidly varying readings were recorded first: 1) rotational speed, 2) turbine inlet pressure, 3) rotameter pressure, 4) load cell reading, 5) volumetric flow rate, 6) turbine inlet and rotameter temperatures, and 7) excitation voltages. Variations in the temperatures and excitation voltages were almost nonexistent. A complete data set required about 15 seconds to record.

Following the no-load data sets, air brake flow was initiated and balanced against the turbine flow until the desired combination of load and speed was obtained. Data were recorded as described above. The load (and thus inlet pressure) was increased progressively until no higher turbine inlet pressure could be achieved. Flow to the air brake was then shut off and the turbine speed increased $10,000 \mathrm{rpm}$. Testing proceeded by varying load first and then rotational speed, until the maximum achievable speed had been reached. At least two data sets were recorded for each condition tested. 
In addition to the data sets described above, two other series were completed: operational acceptance tests and dynamic zero tests. The largely informal operational acceptance tests were conducted to demonstrate the efficacy of various components. Of particular concern were the cradling mechanism and the load ce11; their task was to resolve torques on the order of 0.01 $\mathrm{ft}-1 \mathrm{~b}_{\mathrm{f}}$. The system was tested by placing small masses on the moment arm directly above the load cell under both static and dynamic conditions (turbine stationary and rotating). The 1/4-in. steel washers used most of ten weighed $0.0031 \mathrm{~b}_{\mathrm{m}}$, the equivalent of a torque of about $0.0015 \mathrm{ft}-1 \mathrm{~b}_{\mathrm{f}}$ transmitted through the $0.476 \mathrm{ft}$ moment arm. The data (tabulated in Appendix $C$ and discussed in more detail with the experimental results) indicated that the mechan ism could indeed quantify such minute torques.

The dynamic zero tests were conducted to provide a reference load cell reading at each speed tested. Experiments under static conditions showed that the starting torque in the cradling bearings sometimes biased the load cell reading. However, the vibration present when the turbine was rotating overcame the starting torque and yielded reproduc ible reference readings. These reference values, or dynamic zeroes, were recorded by running the turbine at $10,20,30$ and 40 thousand rpm with the air brake completely removed. Their importance in evaluating the turbine performance is clearly illustrated in the following section on data reduction.

\subsection{DATA REDUCTION PROCEDURE}

The object of the data reduction procedure was to determine the turbine efficiency given the raw data recorded during testing. Turbine efficiency as defined here in is expressed as:

$$
\eta=\frac{(\tau)(\omega)}{(m)(\Delta h)_{S}}
$$

where $\tau$ is the torque delivered to the load, $\mathrm{ft}-1 \mathrm{~b}_{\mathrm{f}} ; \omega$ is the rotational speed, $\mathrm{rad} / \mathrm{sec} ; \mathrm{m}$ is the air mass flow rate, $1 \mathrm{~b}_{\mathrm{m}} / \mathrm{sec}$; and $(\Delta \mathrm{h})_{\mathrm{s}}$ is the change in enthalpy corresponding to an isentropic expansion of air across the turbine. The balance of this section consists of the methods used to calculate each of these four factors. 


\subsubsection{Torque Output}

The torque produced by the prototype was evaluated indirectly by measuring the reaction torque on the housing. The reaction torque, , may be expressed as:

$$
\tau=(L)\left(F_{n e t}\right)
$$

where $L$ is the moment arm length, $0.476 \mathrm{ft}$, and $F_{\text {net }}$ is the net force as indicated by the load cell. F $F_{\text {net }}$ is calculated as:

$$
F_{\text {net }}=\frac{1}{S}\left(\frac{L C_{\text {out }}}{L C_{\text {ex }}}-\frac{D Z_{\text {out }}}{D Z_{\text {ex }}}\right)
$$

where $S$ is the load cell sensitivity, $0.6 \mathrm{mV} / \mathrm{V}_{\text {excitation }} / 1 \mathrm{~b}_{\mathrm{f}}$; $L C_{\text {out }}$ is the load cell output signal, $\mathrm{mV}$; and $L C_{\text {ex }}$ is the excitation voltage, Volts. DZ out and $\mathrm{DZ}$ ex are the output signal and excitation voltage recorded during the dynamic zero test at the appropriate rotational speed. The ratio $\left[\mathrm{Dz}_{\text {out }} /(\mathrm{DZ} \mathrm{ex})\right.$ (S)] represents the force on the load cell due to causes other than the turbine torque.

\subsubsection{Rotational Speed}

The rotational speed, , in $\mathrm{rad} / \mathrm{sec}$ is calculated from the phototachometer reading, $\mathrm{N}$, in $\mathrm{rpm}$ as:

$$
\omega=N\left(\frac{r e v}{\min }\right)\left(2 \pi \frac{\mathrm{rad}}{\mathrm{rev}}\right) /\left(60 \frac{\mathrm{sec}}{\min }\right)
$$

\subsubsection{Mass Flow Rate}

The air mass flow rate is most conveniently calculated as:

$$
m=Q_{p}
$$

where $Q$ is the volumetric flow rate, $\mathrm{ft}^{3} / \mathrm{sec}$, and $\rho$ the air density, $\mathrm{lb}_{\mathrm{m}} / \mathrm{ft}^{3}$. The volumetric flow rate is based on the rotameter calibration curve (Appendix A) and a correction factor that accounts for operating at nonstandard temperature and pressure:

$$
Q=[(0.986) R R-0.179] \sqrt{\frac{P_{s}}{T_{s}} \frac{T_{r}}{P_{r}}}
$$


where $R R$ is the rotameter scale reading; $P_{S}$ is standard pressure, 14.6 psia; $\mathrm{T}_{S}$ is standard temperature, $530^{\circ} \mathrm{R}$; $\mathrm{P}_{\mathrm{r}}$ is the rotameter in let pressure, psia; and $T_{r}$ is the rotameter inlet temperature, ${ }^{0} R$. The air density is calculated via the ideal gas law:

$$
\rho=\left(P_{r}\right)\left(R_{a i r}\right)\left(T_{r}\right)
$$

where $R_{a \text { ir }}$ is the gas constant for air, $53.3 \mathrm{ft}-1 b_{f} / 1 b_{m}{ }^{0} R$.

\subsubsection{Enthalpy Change}

The enthalpy change for any working fluid operating between temperatures $T_{\text {in }}$ and $T_{\text {out }}$ is simply

$$
h=C_{p}\left(T_{\text {in }}-T_{\text {out }}\right)
$$

where the specific heat, $C_{p}, f t-1 b_{f} / 1 b_{m}{ }^{0} R$, is assumed constant and $T_{\text {in }}$ and $T_{\text {out }}$ are the inlet and outlet temperatures, ${ }^{0} R$. The in let temperature is determined by system constraints; the outlet temperature, on the other hand, depends upon the thermodynamic process. Since the objective is to calculate the maximum possible power output from an expanding gas, an isentropic expansion is the logical choice. The following relations are applicable: ${ }^{(4)}$

$$
\begin{aligned}
T_{\text {out }} & =T_{\text {in }}\left(\frac{P_{\text {out }}}{P_{\text {in }}}\right)^{(\gamma-1) / \gamma} \\
C_{p} & =\frac{\gamma}{\gamma-1}\left(R_{\text {air }}\right)
\end{aligned}
$$

where $P_{\text {in }}$ and $P_{\text {out }}$ are the turbine in let and outlet pressures, psia, and $\gamma=$ 1.4 is the ratio of specific heats for air. Inserting Equations 3.9 and 3.10 into Equation 3.8 yields:

$$
\Delta h=\left(\frac{\gamma}{\gamma-1}\right) R_{\text {air }} T_{\text {in }}\left[1-{\frac{P_{\text {out }}}{P_{\text {in }}}}^{(\gamma-1) / \gamma}\right]
$$


The outlet pressure, $P_{\text {out }}$, is atmospheric. The in let pressure is measured as close to the turbine inlet plenum as practical and corrected for losses between the pressure tap location and inlet plenum (typically 2 to 3 psi).

\subsection{EXPERIMENTAL RESULTS AND DISCUSSION}

The prototype was tested during the one-month period from April 6 to May 6, 1982. Three types of tests employing five slightly different turbine configurations were completed. Turbine efficiencies were evaluated at rotational speeds of $10,20,30$, and 40 thousand rpm with in let pressures ranging from 20 to 100 psia. A peak efficiency of 22.5 percent was recorded at an inlet pressure of $98 \mathrm{psia}$ and $40,000 \mathrm{rpm}$. This section includes descriptions of the configurations tested and the results achieved with each. Emphas is is placed upon the final configuration tested for which the most thorough results were recorded.

\subsubsection{Summary of Testing Program}

A description of the five turbine configurations tested and the types of tests run with each is presented in Table 3.2. The configurations differed

TABLE 3.2. Turb ine Configurations Tested

\begin{tabular}{|c|c|c|c|c|}
\hline \multirow[b]{2}{*}{ Configuration } & \multirow[b]{2}{*}{ Description } & \multicolumn{3}{|c|}{ Types of Tests Completed } \\
\hline & & $\begin{array}{r}\text { Operationa } 1 \\
\text { Acceptance } \\
\end{array}$ & $\begin{array}{c}\text { Dynamic } \\
\text { Zero } \\
\end{array}$ & Data \\
\hline A & $\begin{array}{l}\text { Original shaft, open- } \\
\text { raceway bearings }\end{array}$ & $x$ & $x$ & $x$ \\
\hline B & $\begin{array}{l}\text { Identical to } A \text {, but } \\
\text { cleaned \& reassemb led }\end{array}$ & & $x$ & $x$ \\
\hline C & $\begin{array}{l}\text { Original shaft, closed- } \\
\text { raceway bearings }\end{array}$ & & $x$ & $x$ \\
\hline D & $\begin{array}{l}\text { Replacement shaft, } \\
\text { closed-raceway bearings }\end{array}$ & & $x$ & \\
\hline E & $\begin{array}{l}\text { Replacement shaft, one } \\
\text { open- and one closed- } \\
\text { raceway bearing }\end{array}$ & & $x$ & $x$ \\
\hline
\end{tabular}


only by the turbine shaft and bearing types used. The original turbine shaft failed and was replaced with an identical unit. Both open- and closed-raceway bearings were used in the interest of providing a thorough and unbiased evaluation.

A chronological summary of the test program appears in Table 3.3. The early tests were primarily operational acceptance tests that demonstrated the efficacy of the torque measurement apparatus. The static operational acceptance tests (tabulated in Appendix C) showed that the starting torque of the cradling bearings sometimes prevented loads from being transmitted to the load cel1. Under dynamic conditions, however, sufficient vibration was present to maintain the bearings in a nearly constant state of motion; these small movements prevented any binding and allowed the full load to be transmitted. Unfortunately, the vibration also caused oscillations in the load cell output signal that degraded readability.

The configuration A data tests were of a preliminary nature. A bearing on the outboard end of the air brake was removed after sets $A 1$ and $A 2$ because its position could not be reliably fixed. Tests at 30,000 and 40,000 rpm were hampered by bearing problems as evidenced by loud and irregular noises. The resulting efficiencies (Appendix C) were quite low and obviously not representative.

Testing was halted for two weeks until suitable noise-reduction measures had been taken. The configuration B dynamic zero and data tests were also hampered by bearing noise at high rotational speeds. Although the performance was improved slightly, subsequent tests (configuration $E$ ) demonstrated that better efficiencies at high rotational speeds were achievable.

Configuration $C$ and $D$ tests were conducted with the closed-raceway bearings originally supplied with the prototype. Unfortunately, neither set produced useful data. The configuration $C$ tests were halted when it became apparent that the air inlet hose had been improperly installed. The hose was oriented so that it exerted a slight lifting force on the load cell probe, preventing the full turbine torque from being transmitted. In subsequent tests, the hose was oriented to provide a slight pre-load on the load cell.

The configuration $D$ tests were delayed by the fatigue failure of the turbine shaft and the failure of the pressure transducer because of an electrical 


\section{TABLE 3.3. Chronology of Prototype Testing}

4-6-82. Operational acceptance tests A1 through A3 demonstrated that loads as sma 11 as $0.003 \mathrm{lb}_{\mathrm{f}}$ could be resolved in static configuration. Data sets $A 1$ and $A 2$ were completed with outboard bearing in service.

4-7-82. Static (A4, A5, A6) and dynamic (A7, A8, A9) operational acceptance tests investigated the effect of preloading the load cell and further demonstrated the test stand efficacy. Data sets $A 3$ through A6 were completed without the outboard bearing because of positioning problems. A maximum speed of $51,000 \mathrm{rpm}$ was achieved.

4-9-82. Testing was halted by the building manager because of excessive noise.

4-21-82. Testing resumed with noise-absorbing materials in place. Dynamic zero tests $A 1$ through $A 8$ were completed.

4-22-82. Operational acceptance tests $A 10$ and A11 demonstrated that preloading of load cell had no effect on test stand performance. Disassembled, cleaned, lubricated, and reassembled turbine and test stand. Dynamic zero tests B1 and B4 were hindered by sporadic bearing grinding resulting in speed and torque changes.

4-26-82. Data sets B1 through B4 were completed. Maximum speed of 48,000 rpm achieved.

4-27-82. Dynamic zero tests $\mathrm{C} 1$ through $\mathrm{C} 5$ and data sets $\mathrm{C} 1$ and $\mathrm{C} 2$ completed. Flat torque curves indicated that improperly installed air hose restricted turbine housing movement. A maximum speed of 57,800 rpm was achieved.

4-28-82. Pressure transducer failed when leak-testing water penetrated a seal and was replaced with a digital-readout pressure gage.

4-29-82 Turbine shaft failed.

5-4-82. Dynamic zero tests D1 through D5 were completed with closed-raceway bearings. Bearing seized during maximum speed test at 62,000 rpm. Dynamic zero tests E1 through E4 and data set E1 were completed with one open- and one closed-raceway bearing.

5-5-82. Data sets E2 through E5 were completed.

5-6-82. Data sets E6 through E13 were completed. The closed raceway bearing operated erratically at 40,000 rpm (set E13) and eventually seized. 
short. Following completion of the dynamic zero tests, a closed-raceway bearing seized while operating at $62,000 \mathrm{rpm}$. Thus, no data tests were completed with configuration $D$.

The final set of tests was by far the most successful. The configuration $E$ tests were conducted over a three-day period with one open- and one closedraceway bearing. Three series of tests spanning the full range of rotational speeds were completed before another closed raceway bearing failure forced an end to all testing. Data from the configuration $E$ tests are plotted and discussed in the following section.

\subsubsection{Configuration E Test Results}

The turbine efficiencies determined in the three series of configuration $E$ tests are plotted in Figures 3.4 through 3.7 as functions of turbine inlet pressure. Data for the four speeds tested are plotted separately for clarity. Series 3 data at 40,000 rpm were recorded and are tabulated in Appendix C; however, the bearing failure that halted testing was obviously in progress as those data were taken, reducing the efficiencies sharply.

The trends in turbine efficiency with inlet pressure and rotational speed are clear from the figures. With the exception of the Series 3 data at $10,000 \mathrm{rpm}$ (to be discussed shortly), efficiency increases gradually with inlet pressure. Efficiency also increases with rotational speed, ranging from approximately 10 percent at $10,000 \mathrm{rpm}$ to a peak value of 22.5 percent at $40,000 \mathrm{rpm}$. Based upon these trends, one would expect higher efficiencies at increased speed and inlet pressure. The relative flatness of the curves, however, suggests that the increase with inlet pressure would be slight. Testing at higher speeds and pressures was not possible because of air system limitations. Further comments on efficiency trends appear in Section 4 where a performance model is discussed.

Scatter in the data within individual series is minimal, particularly at higher inlet pressures where the torque readings are increased. A worst-case uncertainty analysis (Appendix D) indicates that the uncertainty in individual data points ranges up to 15.6 percent. Taking redundant data points, however, reduces the uncertainty to about 11 percent. Significant contributors to uncertainty include: 1) poor readability of the load cell output due to vibration, 


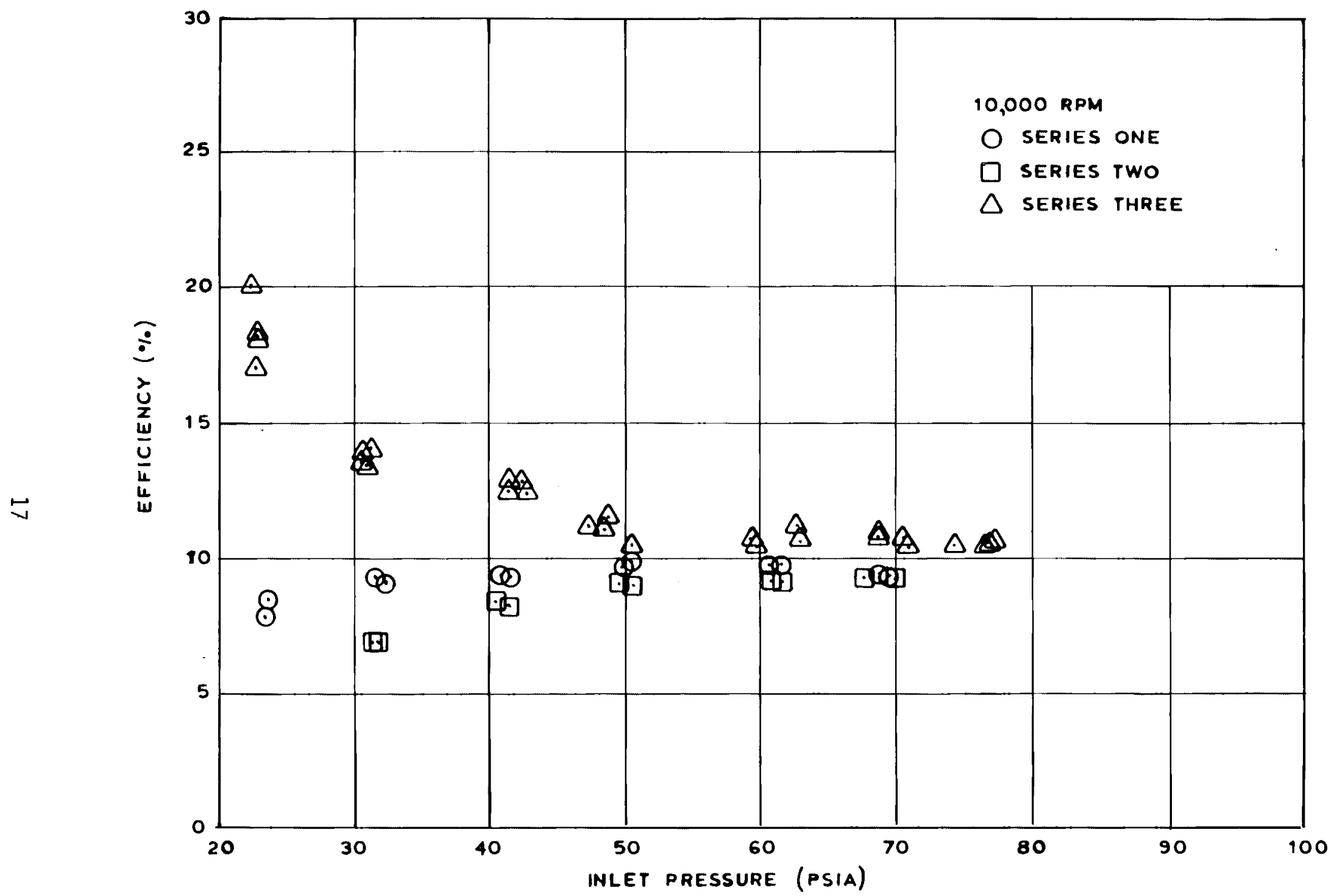

FIGURE 3.4. Turbine Efficiency Versus Inlet Pressure at 10,000 RPM 


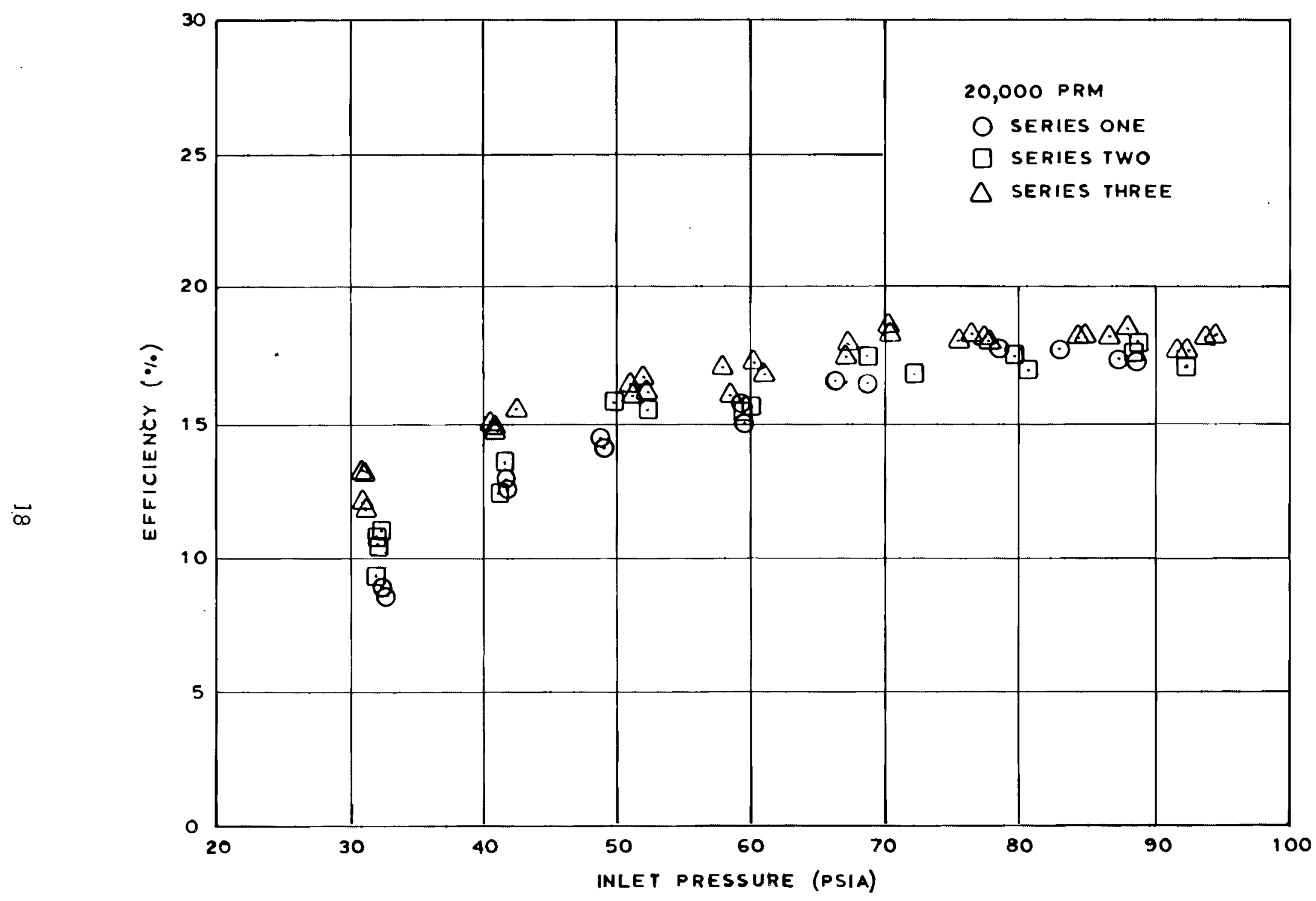

FIGURE 3.5. Turbine Efficiency Versus In let Pressure at 20,000 RPM 


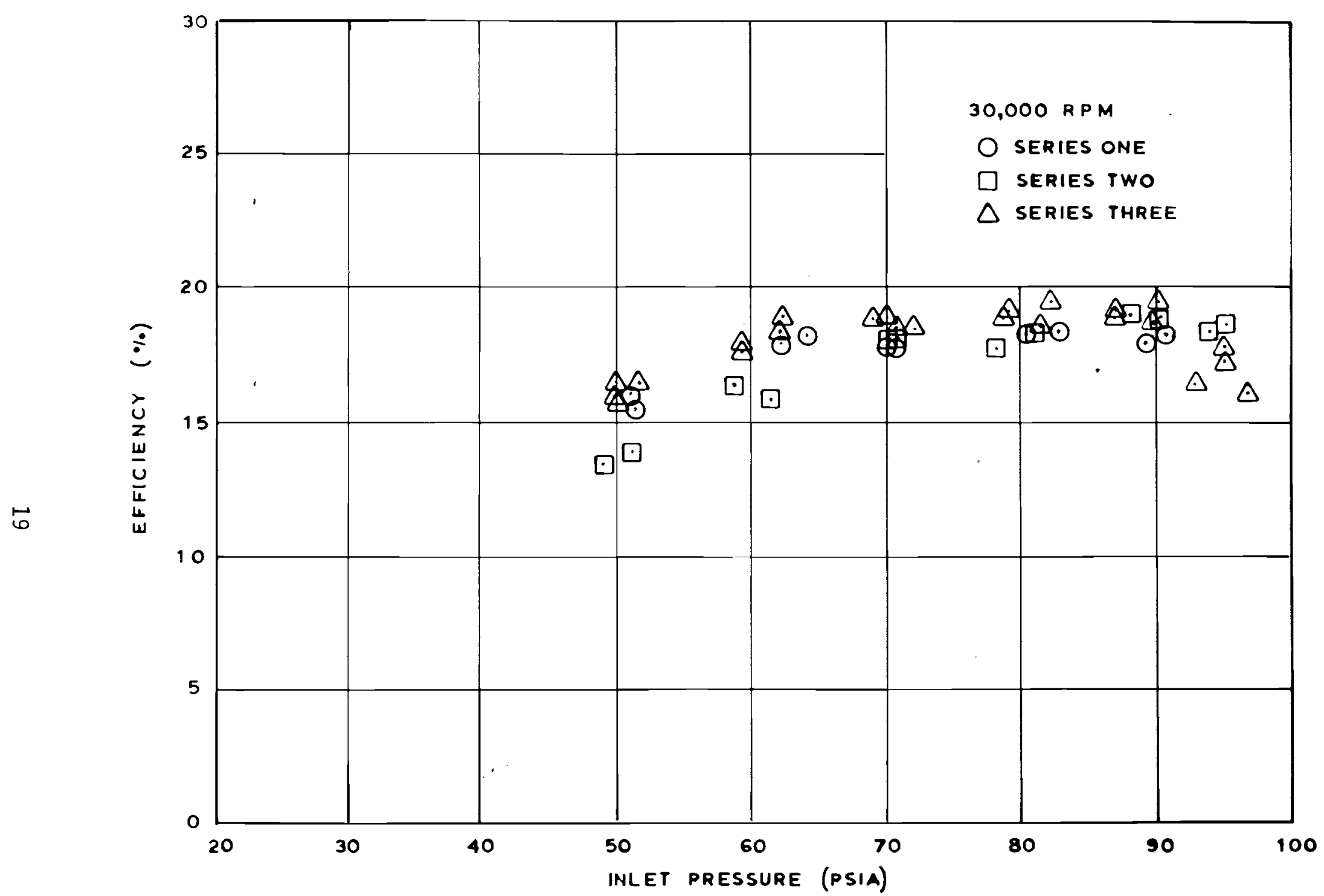

FIGURE 3.6. Turbine Efficiency Versus Inlet Pressure at 30,000 RPM 


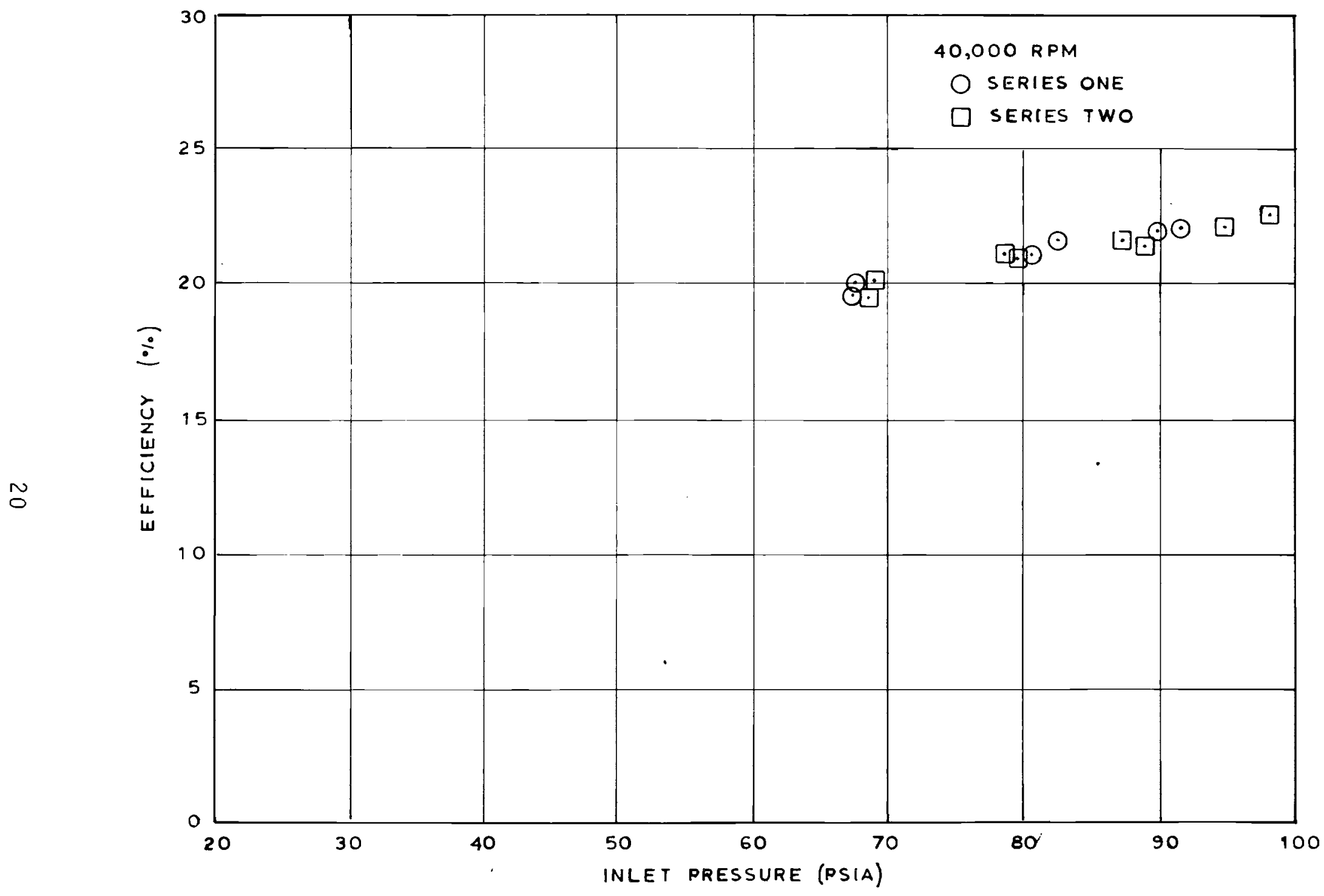

FIGURE 3.7. Turbine Efficiency Versus Inlet Pressure at 40,000 RPM 
2) pressure changes due to compressor cycling, and 3) limited resolution of the rotameter scale, particularly at low flow rates. The relative magnitudes of all significant contributing factors to the uncertainty in turbine efficiency decrease with increasing in let pressure.

Scatter between series is significantly greater than that within a given series, particularly at 10,000 rpm. The three series of configuration $E$ tests are distinct only because of temporal separation; no modification of any sort was made to the turbine or test stand between series. However, long experience with the turbine indicated that factors beyond direct control, particularly bearing performance, could affect the testing significantly.

This fact was graphically illustrated while recording configuration $E$ dynamic zeroes at 40,000 rpm. The turbine bearings were causing large oscillations in output torque as well as a great deal of noise. The turbine became quiet and simultaneously increased in speed to $48,000 \mathrm{rpm}$; the "set" of the bearings had obviously improved significantly. To reduce the rotational speed to $40,000 \mathrm{rpm}$ aga in required a 25 percent reduction in air flow. Although a worst case, this example shows the potential effect of changes in turbine components beyond direct control.

The discrepancy at 10,000 rpm between the series 3 data and the previous two series decreases sharply with increasing inlet pressure. The series 3 data are highly suspect because they conflict with the trends exhibited at all speeds by the balance of the data. A variable that is significant at low inlet pressures but much less so at high pressures is clearly at fault. Such a variable is the dynamic zero, since efficiency is proportional to the net transmitted force calculated as:

$$
F_{\text {net }}=\frac{1}{S}\left(\frac{L C_{\text {out }}}{L C_{\text {ex }}}-\frac{D Z_{\text {out }}}{D Z_{\text {ex }}}\right)
$$

At low inlet pressures the load cell output, $L C_{\text {out }}$, is only slightly greater than $\mathrm{DZ}_{\text {out }}$, the dynamic zero output. (Excitation voltages were virtually identical.) At high pressures, however, the difference between $L C_{\text {out }}$ and $D Z_{\text {out }}$ is substantial, so the absolute value of $\mathrm{DZ}_{\text {out }}$ is much less significant. The same set of dynamic zero readings was used to reduce all 
three series of configuration $E$ tests. However, in view of the many hours of running time that transpired between the dynamic zero tests and the series 3 tests, it is not unreasonable to suspect a slight change in the dynamic zero value. Calculations based on the data tabulated in Appendix $C$ show that only a 10 percent increase in the dynamic zero for the series 3 tests is required to provide excellent agreement between all three series at all inlet pressures. Thus, the aberrant series 3 results at $10,000 \mathrm{rpm}$ are probably due to a slight error in the dynamic zero value used in data reduction.

In summary, the Gamell turbine prototype was tested with air over a range of inlet pressures from 20 to 100 psia and speeds of $10,20,30$ and 40 thousand rpm. The peak efficiency of 22.5 percent was recorded at a pressure of 98 psia and a speed of $40,000 \mathrm{rpm}$. Efficiency increased slightly with speed and inlet pressure over the full range tested. The test program was hindered somewhat by mechanical failures. The turbine bearings in particular were quite troublesome, with two instances of outright failure and numerous cases of erratic performance. Any future testing should be undertaken only after bearings suitable for prolonged high-speed operation are procured. 


\subsection{PERFORMANCE MODELING AND PREDICTION}

A model of the Gamel1 turbine was developed to assist in interpreting the experimental results. To rigorously analyze the complex phenomena occurring in the turbine was beyond the scope of this effort; a macroscopic approach incorporating several favorable assumptions was taken instead to place a reasonable upper bound on the turbine efficiency. The predicted efficiency as a function of rotational speed is compared with the experimental values described in Section 3.4.

The evaluation described herein is of limited use unless the results can be extrapolated to conditions other than those tested. Dimensional analysis is the tool most frequently used to perform such extrapolations. This section also includes a discussion of turbomachine scaling parameters, emphasizing those that apply directly to the Gamell turbine.

\subsection{GAMELL TURBINE PERFORMANCE MODEL}

The Gamell turbine is described by its proponents as a combination impulsedrag device. As a partial admission tangential flow machine, it is similar in some respects to the Pelton wheel, a widely used impulse turbine. (5) To adequately model the impulse and drag effects occurring in the Game 11 turbine is an exceedingly complex task; the model described herein circumvents that difficulty by treating only the gross effects of momentum change rather than the detailed mechanisms responsible. Two flow features are examined in the model: 1) flow through the air inlet nozzles, and 2) the interaction between the fluid jet and the turbine blade. Significant loss mechanisms are also described. Turbine efficiency as a function of rotational speed is calculated and compared with experimental results.

\subsubsection{Air Inlet Nozzle Flow}

The Gamell turbine prototype is equipped with twelve air inlet nozzles in the inner housing ring as shown in Figure 3.1. Each nozzle consists of a 0.046-in. diameter hole drilled obliquely through the ring. A 0.093-in. diameter "spotface" is used to provide a square inlet as shown in Figure 4.1. The nozzle exit is roughly elliptical, although machining imperfections in the prototype distort the shape somewhat. 


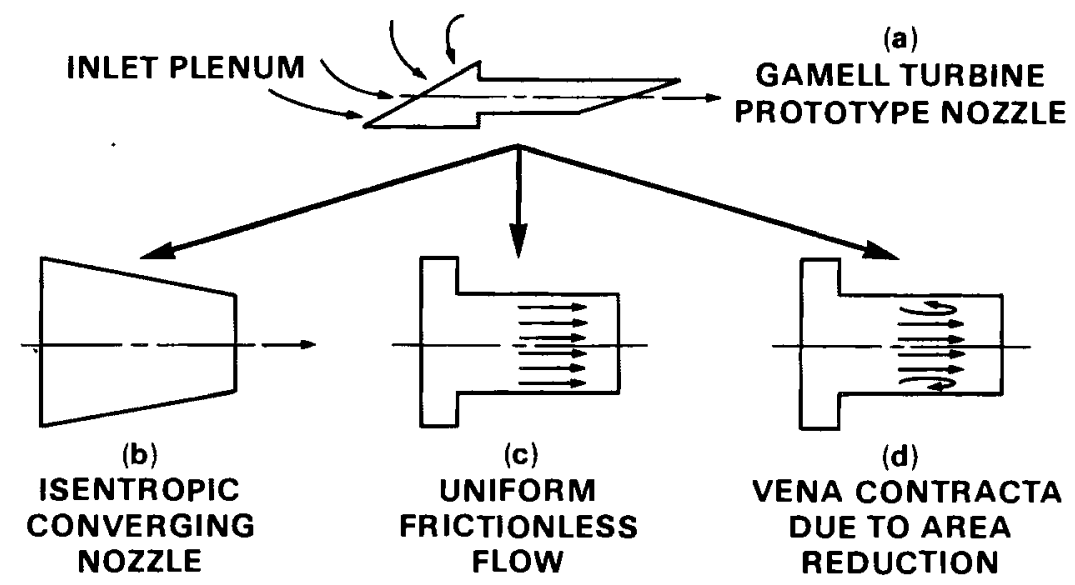

FIGURE 4.1. Gamell Turbine Air Inlet Nozzle and Three Alternative Models

Three configurations were evaluated as models for the prototype nozzles. The three, illustrated in Figure 4.1, include: 1) a converging nozzle in which flow is isentropic, 2) a straight cylindrical nozzle with a uniform velocity profile occupying the full area, and 3) a straight cylindrical nozzle in which the sharp-edged inlet creates a "vena contracta" resulting in higher jet velocities.

The three configurations were evaluated by calculating nozzle exit velocities and comparing them to turbine blade tip velocities at the four rotational speeds tested. Inlet plenum pressures and temperatures from actual tests were used. The reduced-area cylindrical nozzle model yielded the highest velocities and was therefore the most acceptable. However, the peak velocity of $630 \mathrm{ft} / \mathrm{sec}$ predicted by this model was still far below the maximum experimental blade tip velocity $(810 \mathrm{ft} / \mathrm{sec}$ at $62,000 \mathrm{rpm})$. Since the jet velocity must exceed the blade tip velocity, none of the three models was satisfactory. Therefore, in keeping with the objective of placing an upper bound on the turbine efficiency, a favorable assumption was made: the nozzle exit velocity was assumed sonic, the maximum achievable in a converging nozzle or constant-area duct. ${ }^{(6)}$ The effect of this assumption is illustrated in the following section, where an expression for turbine efficiency incorporating nozzle exit velocity is developed. 


\subsubsection{Air Jet-Turbine Blade Interaction}

The air jet leaving the inlet nozzle strikes the turbine blade as illustrated in Figure $4.2(a)$. The jet is of density, travels at velocity $v_{1}$, and has a mass flow rate equal to $1 / 12$ the total turbine flow rate. The tur bine whee 1 of radius $R$ rotates at radians/second, resulting in a blade tip velocity of

$$
U=\omega R
$$

Velocity polygons and a close-up view of the turbine blade are shown in Figure 4.2(b). The blade is aligned axially. The sides of the blade slope upward at 37 degrees relative to a line tangent to the whee 1 minor diameter. The knurled top of the blade is 0.01 inches wide, and the base is 0.05 inches wide. The blade height is 0.015 inches. The inlet velocity polygon consists of three vectors all parallel to the tangential ax is: 1) the absolute jet velocity, $\vec{v}_{1}, 2$ ) the turbine whee l tip velocity, $\vec{U}$, and 3 ) the jet velocity relative to the whee 1 tip, $\vec{w}_{1}=\vec{v}_{1}-\vec{u}$.

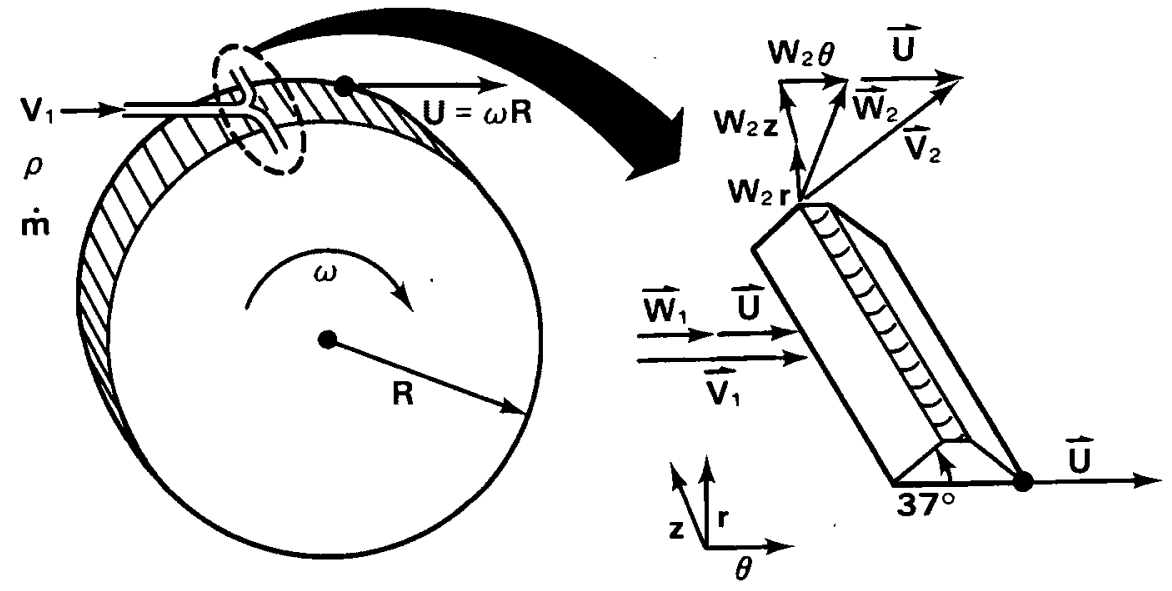

(a)

(b)

FIGURE 4.2. Air Jet and Turbine Blade Geometry with Velocity Polygons 
The exit velocity polygon also consists of the wheel tip velocity, $\vec{U}$, the jet absolute velocity, $\overrightarrow{2}$, and the jet relative velocity, $\vec{w}_{2}=\vec{v}_{2}-\vec{U}$. The magnitude and direction of $\vec{U}$ are, of course, constant. Assuming that friction between the blade face and the jet is negligible, the magnitudes of the inlet and exit relative velocities are equal:

$$
\left|\vec{w}_{2}\right|=\left|\vec{w}_{1}\right|
$$

However, the direction of $\vec{W}_{2}$ (and thus the magnitude and direction of $\vec{v}_{2}$ ) is not immediately apparent. A portion of the jet is undoubtedly deflerted radially outward and enters the tip clearance area, whose height of 0.008 inches is more than half the blade height. Fluid passing over the blade tips is slowed by drag against the blades and the turbine housing and eventually turns axially, radially inward, and axially again to pass through the exit ports. Part of the jet may also be deflected axially at the outset, particularly since that is the shortest path to the exit ports.

The significance of the direction of $\vec{W}_{2}$ is revealed by introducing the Euler equation for turbomachines: ${ }^{(5)}$

$$
E_{\text {out }}=\frac{\omega}{g}\left(V_{1 \theta} R_{1}-V_{2 \theta} R_{2}\right)
$$

where $E_{\text {out }}$ is the energy transfer per unit mass of fluid, $g$ is the gravitational constant out, and $v_{1 \theta}$ and $v_{2 \theta}$ are the tangential components of the absolute inlet and exit velocities. The expression in parentheses is proportional to the change in angular momentum of the fluid, which in turn is proportional to the torque exerted on the turbine wheel. The rotational speed, $\omega$, is proportional to the distance through which the torque is applied. For the Game 11 turbine,

$$
R_{1}=R_{2}=R
$$

and

$$
U=\omega R
$$

thus

$$
E_{\text {out }}=\frac{U}{g}\left(V_{1 \theta}-V_{2 \theta}\right)
$$


Now use the velocity polygons to evaluate $V_{1 \Theta}$ and $V_{2 \theta}$ :

$$
v_{10}=U+w_{1 \theta}
$$

The vector $\vec{W}_{1}$ is parallel to the tangential axis, so

$$
\begin{gathered}
w_{1 \Theta}=\left|\vec{w}_{1}\right| \equiv w_{1} \\
v_{1 \Theta}=U+w_{1} \\
v_{2 \theta}=U+w_{2 \theta}
\end{gathered}
$$

Define the angle $\beta$ to be the angle through which the jet relative velocity is deflected by striking the blade. The tangential component of the exit relative velocity is then

$$
\begin{gathered}
W_{2 \Theta}=\left|\vec{W}_{2}\right| \cos \beta \equiv W_{2} \cos \beta \\
V_{2 \Theta}=U+W_{2} \cos \beta
\end{gathered}
$$

Now combine Equations $4.2,4.6,4.9$, and 4.12:

$$
\begin{gathered}
E_{\text {out }}=\frac{U}{g}\left[\left(U+W_{1}\right)-\left(U+W_{1} \cos \beta\right)\right] \\
E_{\text {out }}=\frac{U}{g} W_{1}(1-\cos \beta)
\end{gathered}
$$

Equation 4.14 clearly demonstrates the significance of the direction of the exit relative velocity vector, $\vec{W}_{2}$. If the jet is deflected radially outward, the angle $\beta$ is 37 degrees; if the jet is deflected axially, $\beta$ is 90 degrees. An increase in $\beta$ corresponds to greater energy transfer from the fluid to the blade. Well-designed impulse turbines such as the Pelton wheel deflect the fluid through angles as great as $\beta=170$ degrees. (5)

In the analysis, the fluid is assumed to exit the blade axially ( $\beta=90$ degress) for two reasons. First, this highly optimistic assumption leads to the maximum possible energy transfer and thus places an upper bound on turbine efficiency. Second, a portion of the tangential momentum of the fluid passing over the blade tips is transmitted to the turbine wheel as drag. The axial flow assumption eliminates the need to model the exceedingly complex flow in the tip clearance area. 
The theoretical power output from the turbine is the product of the mass flow rate and the energy transfer rate per unit mass

$$
\begin{gathered}
P_{\text {out }}=(\rho g Q) E_{\text {out }} \\
P_{\text {out }}=\rho Q U W_{1}(1-\cos \beta)
\end{gathered}
$$

The energy in the air entering the turbine is present in the form of kinetic energy and static pressure in excess of atmospheric

$$
E_{\text {in }}=\frac{v_{1}^{2}}{2 g}+\frac{P_{1}}{\rho}
$$

where $P_{1}$ is the jet gage pressure at the nozzle exit. The static pressure, however, exerts no net force on the turbine wheel because it exerts equal force in all directions. To place an upper bound on the turbine efficiency, the jet static pressure is assumed atmospheric, implying that a well-designed nozzle converted all the energy of the incoming air into kinetic energy. The power input to the turbine is

$$
\begin{gathered}
P_{\text {in }}=(\dot{m})\left(E_{i n}\right) \\
P_{\text {in }}=\rho Q \frac{V_{1}^{2}}{2}
\end{gathered}
$$

Neglecting all losses, the turbine efficiency is

$$
\begin{gathered}
n=\frac{P_{\text {out }}}{P_{\text {in }}} \\
n=\frac{\rho Q U W_{1}(1=\cos \beta)}{\rho Q V_{1}^{2} / 2}
\end{gathered}
$$

Now insert $w_{1}=v_{1}-U$ :

$$
n=2 \frac{U}{V_{1}}\left(1-\frac{U}{V_{1}}\right)(1-\cos \beta)
$$

Differentiation of Equation 4.22 with respect to the velocity ratio $U / V_{1}$ shows that the efficiency is maximized when

$$
\mathrm{U} / \mathrm{v}_{1}=0.5
$$


which states that the jet velocity should be twice the turbine blade tip velocity. Inserting this value and $B=90$ degrees into Equation 4.22 yields

$$
\begin{gathered}
n_{\text {max }}=(2)(.5)(1-.5)\left(1-\cos 90^{\circ}\right) \\
n_{\text {max }}=0.5
\end{gathered}
$$

Thus, according to this analysis, the maximum possible efficiency of a tangential flow turbine with straight axial blades is 50 percent, a direct consequence of turning the fluid only 90 degrees relative to the turbine blade. The discussion of loss mechanisms presented in the following section indicates that significantly lower efficiencies may be expected for the Gamell turbine. Following that discussion, the model predictions are compared with the experimental results described in Section 3.4.

\subsubsection{Turbine Loss Mechanisms}

A number of loss mechanisms have been identified and well documented in the turbo-machinery literature. Two mechanisms were mentioned in previous sections of this report: bearing losses and losses due to non-optimal velocity ratios. Priest and Roelke, in a text edited by Glassman, ${ }^{(2)}$ identify several other loss mechanisms including the following:

- boundary-layer losses due to friction between the working fluid and machine surfaces;

- tip-clearance losses caused by the passage of fluid through the radial clearance gap;

- disk-friction losses due to the circulation of fluid between the rotating disk and stationary housing; and

- partial admission losses due to pumping of air in the inactive regions and to the filling and emptying of blades around the nozzles.

of these mechanisms, only the velocity-ratio and tip-clearance losses will be treated quantitatively. The bearing losses observed experimentally were highly intermittent and thus difficult to evaluate. The boundary-layer and tipclearance regions in the Gamell turbine are very nearly coincidental; to account 
for both mechanisims might well be double jeopardy. Losses due to disk friction were evaluated for a sample case and were found to be slight. Finally, partial-admission losses were judged likely to be negligible because the Gamell turbine, with twelve inlet nozzles, is nearly a full-admission device.

Turbine efficiency as a function of velocity ratio, calculated via Equation 4.22 , is plotted in Figure 4.3 for the case of $\beta=90$ degrees. The curve is symmetric about a peak value of 50 percent at $U / V_{1}=0.5$. The efficiency is zero at $U / V_{1}=0$ because the turbine wheel is not rotating and therefore delivers no power to the load. At a velocity ratio $U / V_{1}=1.0$, the jet and blade-tip velocities are equal; the jet is not deflected by the blade, and no momentum exchange takes place.

The effect of blade-tip clearance on turbine efficiency is illustrated in Figure 4.4. The solid line and triangular data points were abstracted from Glassman; ${ }^{(2)}$ the dotted line is a linear extrapolation performed for the current work. The ordinate of Figure 4.4 is the fraction of the turbine efficiency that would exist if no tip-clearance losses were present. The abscissa

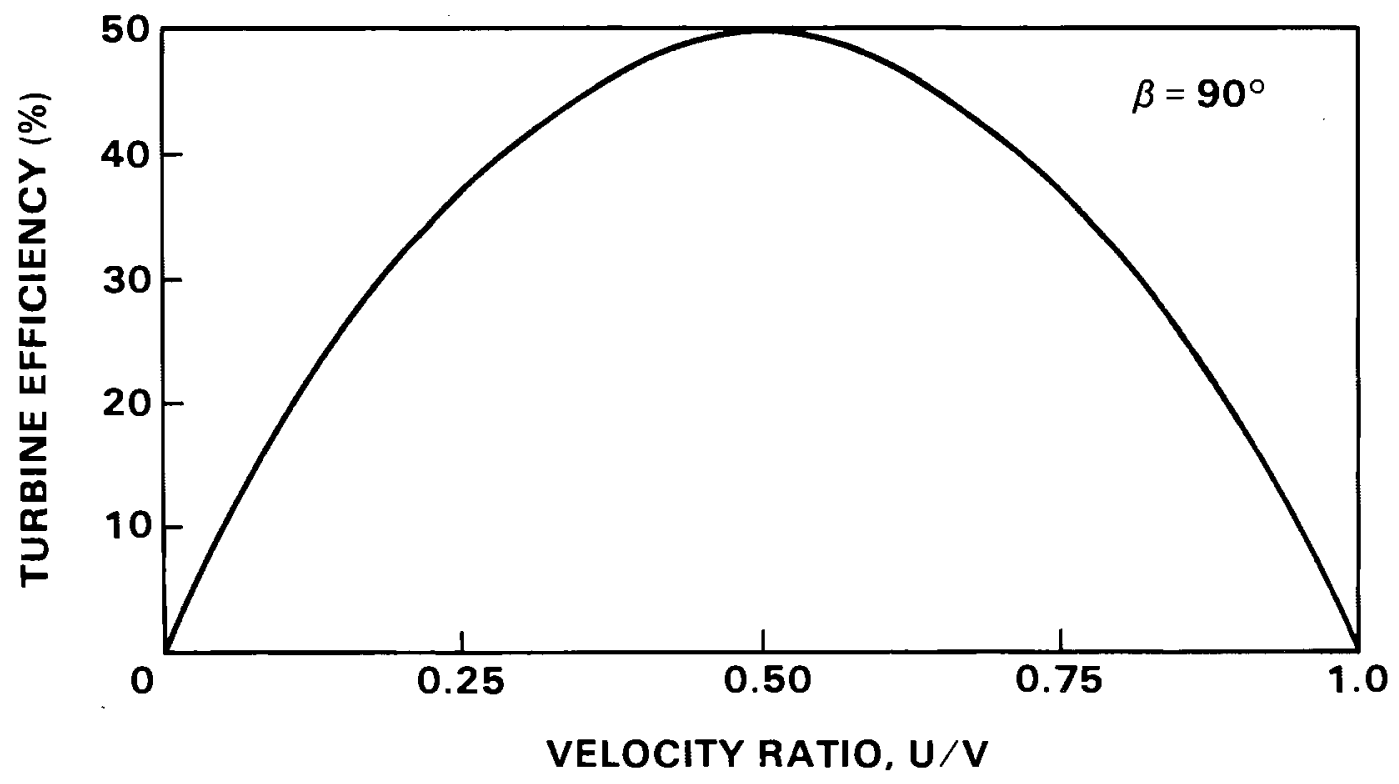

FIGURE 4.3. Turbine Efficiency Versus Velocity Ratio 


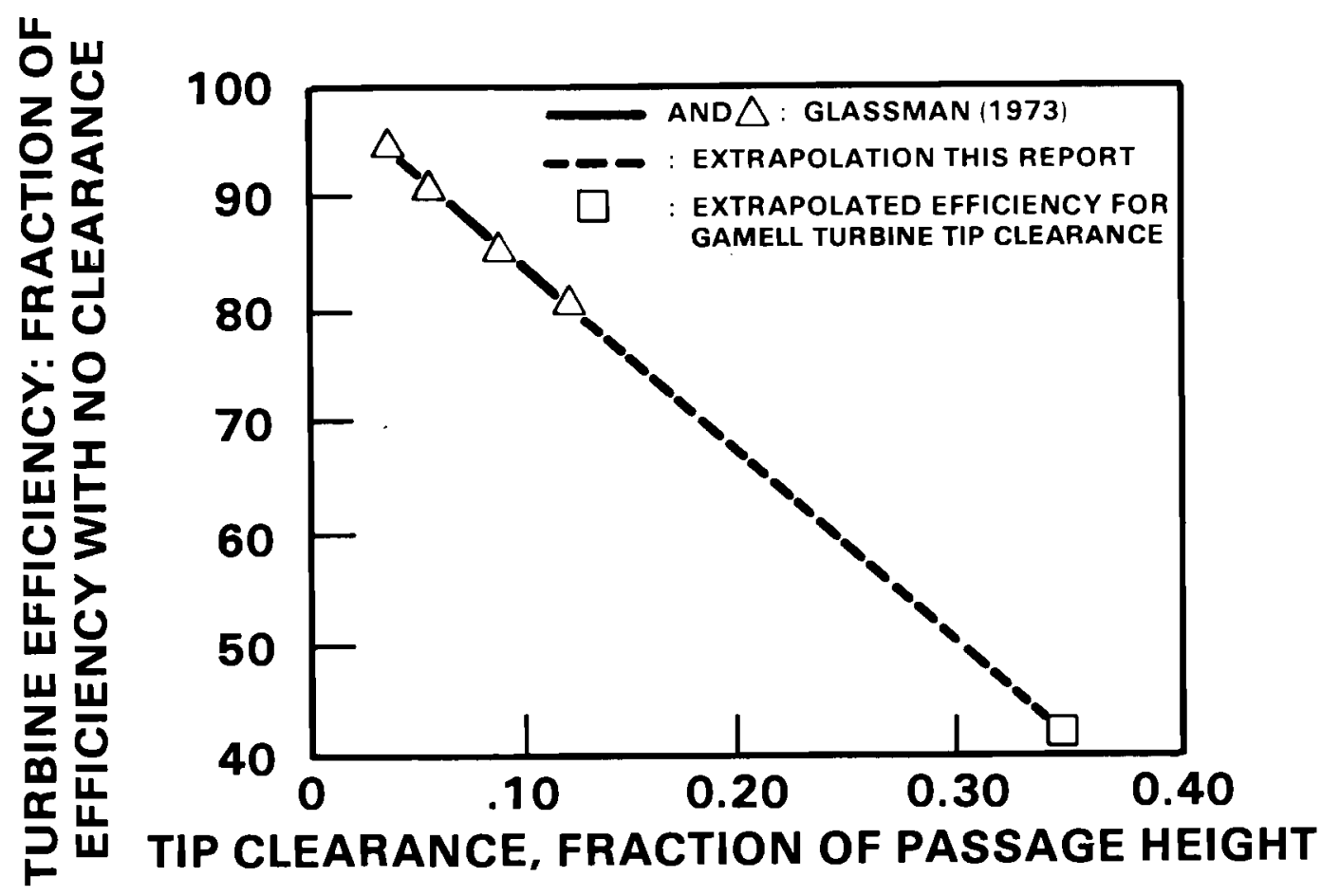

FIGURE 4.4. Effect of Tip Clearance on Turbine Efficiency

is the tip clearance expressed as a fraction of total passage height. For the Gamell turbine, the clearance fraction CF is

$$
\mathrm{CF}=(.008) /(.008+.015)=.348
$$

where the tip clearance is .008 inches and the blade height .015 inches.

The tip-clearance efficiency, $n_{t c}$, corresponding to this clearance fraction is 42 percent. When multiplied by the peak efficiency of 50 percent determined in the previous section (the maximum efficiency attainable with no loss mechanisms whatsoever), the resulting turbine efficiency is 21 percent.

The extrapolation of Figure 4.4 must be used with caution, however. The range of the extrapolation is quite broad; furthermore, the closely-spaced knurled blade tips of the Gamell turbine are quite possibly more adept at extracting momentum from fluid passing over them than conventional impulseturbine blades. For lack of a more directly applicable model, however, a tipclearance efficiency of 42 percent will be used in the following section in which the model predictions are compared with experimental results. 


\subsubsection{Comparison Between Model and Experiment}

The model developed in the previous two sections is capable of predicting turbine efficiency as a function of velocity ratio while accounting for tipclearance losses. The resulting expression for turbine efficiency is

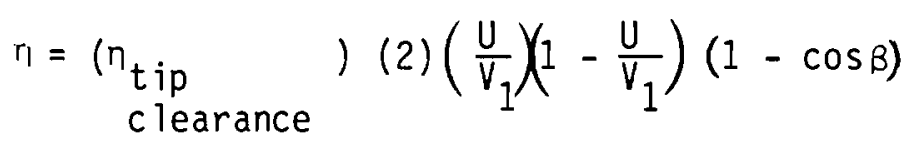

where the tip clearance efficiency extrapolated via Figure 4.4 is 42 percent; the jet turning angle, , is 90 degrees; the blade tip velocity, $U$, is calculated via Equation 4.5; and the jet velocity, $v_{1}$, is assumed sonic and is calculated as

$$
\begin{aligned}
v_{1}=c & =\sqrt{\gamma R_{\text {air }} T_{1}} \\
T_{1} & =T_{0} \quad\left(\frac{P_{1}}{P_{0}}\right)^{(\gamma-1) / \gamma}
\end{aligned}
$$

Where $T_{1}$ is the nozzle exit temperature, ${ }^{O} R ; T_{0}$ is the in let plenum temperature, typically $533^{\circ} R$; and $P_{1} / P_{0}$ is the nozzle pressure ratio, 0.528 for choked flow. The resulting air jet velocity is $v_{1}=1030 \mathrm{ft} / \mathrm{sec}$.

The efficiencies predicted by Equation 4.27 are plotted in Figure 4.5. Both rotational speed and blade-tip velocity are indicated on the abscissa.

Also plotted in Figure 4.5 are the peak efficiencies determined experimentally at the four rotational speeds tested. In general, the experimental efficiencies exceed the model values slightly. Bear in mind, however, that peak values were used, and that individual data points are subject to an uncertainty of roughly 15 percent (Appendix D). Recall also the broad extrapolation required to determine the tip-clearance efficiency. In view of these qualifications, the level of agreement between experiment and model is quite satisfactory. Note that the model predicts a decrease in turbine efficiency beyond $40,000 \mathrm{rpm}$ in spite of the assumption of sonic jet velocity. To achieve increased efficiency at higher rotational speeds would require the use of a converging-diverging nozzle. 


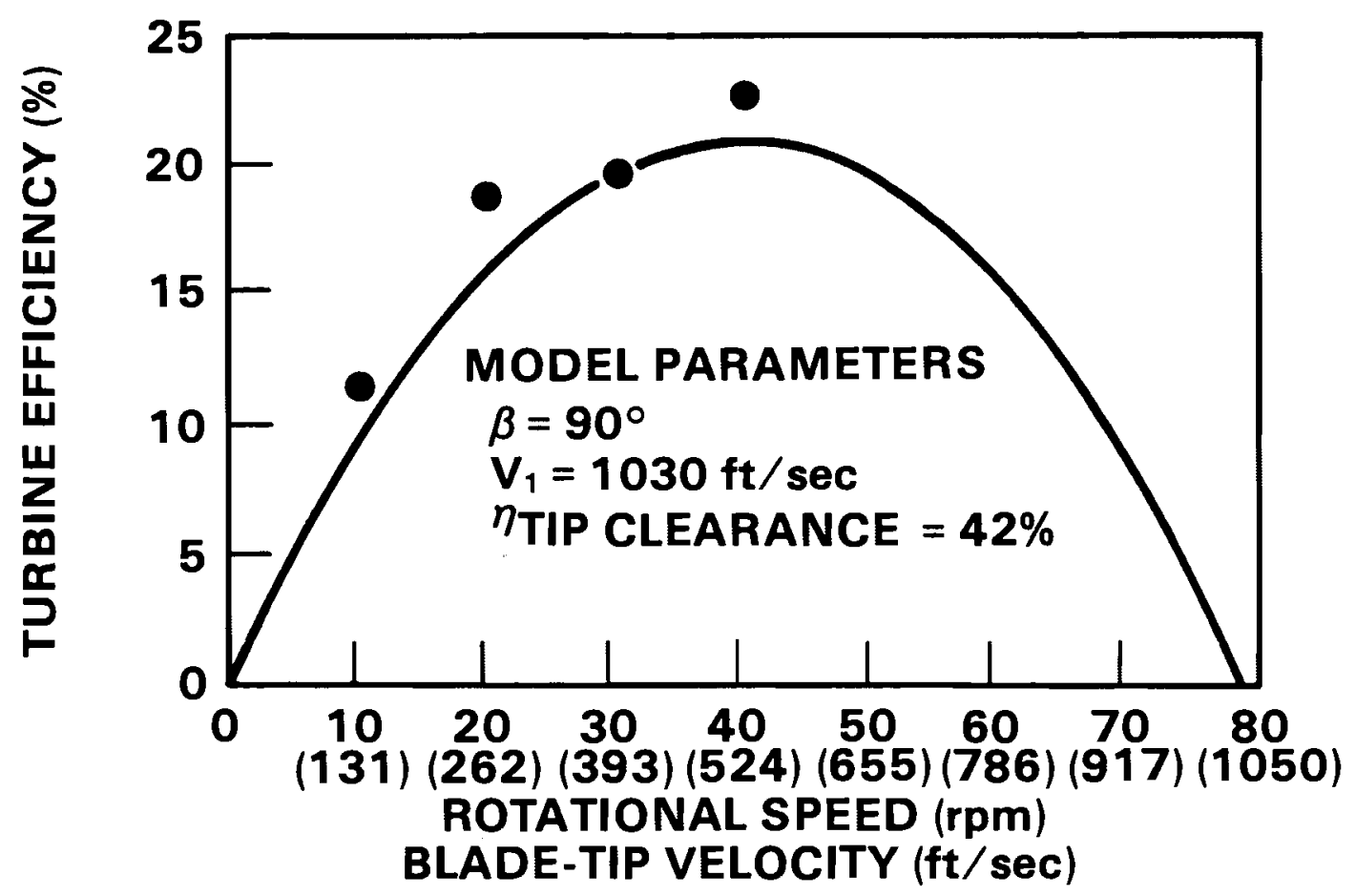

FIGURE 4.5. Turbine Model and Peak Experimental Efficiencies

\subsection{TURBOMACHINERY SCALING RELATIONSHIPS}

Only in rare instances is a prototype turbomachine tested at the same conditions under which the finished product is expected to operate. In all other cases, testing is performed over a limited range of presumably benign conditions; dimensionless scaling groups are then used to predict performance under anticipated operating conditions. The derivation and applicability of these groups are we 11 documented. $(2,5,7,8)$ This section includes descriptions of several frequently-cited dimensionless groups, two of which are chosen for use with the Gamell turbine analysis.

Perhaps the most commonly used turbo-machine scaling group is specific speed, $\mathrm{N}_{\mathrm{S}}$. For compressible-flow turbines, specific speed is often expressed as: $(5)$

$$
N_{S}=\frac{N \sqrt{P}}{\sqrt{\rho}(g H)^{1.25}}
$$


This form is dimensionless with $N$ in $\mathrm{rad} / \mathrm{sec}, \mathrm{P}$ in $\mathrm{ft}-1 \mathrm{~b}_{\mathrm{f}} / \mathrm{sec}$, in slugs/ $\mathrm{ft}^{3}$, and $\mathrm{gH}$ in $\mathrm{ft}^{2} / \mathrm{sec}^{2}$. For pumps, specific speed is frequently written as

$$
N_{S}=\frac{N \sqrt{Q}}{(g H) \cdot 75}
$$

where $Q$ is the volumetric flow rate. Equations 4.29 and 4.30 are related by the expression

$$
P=\rho Q(g H)
$$

which is strictly true only at 100 percent efficiency. Specific speed is properly evaluated at conditions corresponding to peak efficiency. Each class of turbomachines has its peak efficiency over a narrow range of specific speed. Impulse turbines, for instance, perform best at low specific speeds (high head and low flow rate).

A group that excludes the rotational speed is the specific diameter, $D_{s}$, expressed as ${ }^{(2)}$

$$
D_{S}=\frac{D(g H)^{25}}{\sqrt{Q}}
$$

where $D$ is the wheel diamter, ft. The volumetric flow rate in compressible flow machines is evaluated at exit conditions.

A third dimensionless quantity is the specific power, $P_{S}$,

$$
P_{S}=\frac{P}{\rho N^{3} D^{5}}
$$

which relates power, density, rotational speed, and wheel diameter.

The ratio of the fluid head to the kinetic energy of the fluid running at the rotor tangential speed is expressed as specific head.

$$
H_{S}=g H /\left(N^{2} D^{2}\right)
$$


The flow coefficient or specific capacity is the volume flowrate (always measured at the turbine exhaust) through a machine of unit diameter operating at unit speed. Thus,

$$
Q_{S}=Q / N D^{3}
$$

Two groups of limited applicability are the Reynolds number, Re, and Mach number, M. Reynolds number is important when pumping high viscosity fluids and may be expressed as ${ }^{(8)}$

$$
\operatorname{Re}=\rho N D^{2} / \mu
$$

where $\mu$ is the fluid viscosity. Nearly all turbines operate with low-viscosity fluids and have Reynolds numbers we 11 into the turbulent regime; in such cases, Reynolds number scaling is of secondary importance.

The Mach number form most frequently employed is the blade Mach number, expressed as ${ }^{(8)}$

$$
M=N D / C
$$

where $c$ is the local speed of sound and the product (ND) is proportional to blade speed. The Mach number is significant only for machines that operate at near-sonic or supersonic velocity.

The use of the dimensionless groups for scaling is strictly correct only if the efficiencies at the two conditions are equal. However, it is well known that larger diameter turbines are more efficient than smaller; 01 son ${ }^{(5)}$ recommends the use of the following expression to circumvent this problem:

$$
\frac{1-n_{\text {small }}}{1-n_{\text {large }}}=\left(\frac{D_{\text {large }}}{D_{\text {sma } 11}}\right)^{0.2}
$$

In the Gamell turbine evaluation, six physical quantities are of consequence: 1) power, $\mathrm{P} ; 2$ ) head, $(\mathrm{gH})$; 3) flow rate, $\mathrm{Q}$; 4) rotational speed, $\mathrm{N}$; 5) diameter, $D$; and 6 ) density, $\rho$. To express these quantities requires the use of four fundamental units: mass, length, time, and temperature. The number of parameters required to perform dimensional analys is is $(7)$ 
(number parameters) $=$ (number of physical quantities) -

(number of units required)

Thus, two dimensionless groups are required to correlate the experimental results. The groups specific speed and specific head were selected for deriving a generalized scaling relationship. By squaring the specific speed equation and ratioing the following is yielded:

$$
\mathrm{P}_{2}=\left(\frac{\mathrm{N}_{1}}{\mathrm{~N}_{2}}\right)^{2}\left(\frac{\mathrm{P}_{2}}{\mathrm{\rho}_{1}}\right)\left(\frac{\mathrm{H}_{2}}{\mathrm{H}_{1}}\right)^{2.5} \mathrm{P}_{1}
$$

where the subscript one refers to the base conditions and two to the new conditions. Similarly, the specific head equation is ratioed and rearranged to yield

$$
\left(\frac{\mathrm{N}_{1}}{\mathrm{~N}_{2}}\right)^{2}=\left(\frac{\mathrm{D}_{2}}{\mathrm{D}_{1}}\right)^{2}\left(\frac{\mathrm{H}_{1}}{\mathrm{H}_{2}}\right)
$$

This is then substituted back into equation 4.40 to yield the final scaling relationship:

$$
P_{2}=P_{1}\left(\frac{D_{2}}{D_{1}}\right)^{2}\left(\frac{\rho_{2}}{\rho_{1}}\right)\left(\frac{H_{2}}{H_{1}}\right)^{1.5} \frac{n_{2}}{n_{1}}
$$

where the efficiencies are scaled based on diameter according to Equation 4.38.

Using this scaling relationship, the peak test conditions were scaled to diameters up to 12 inches, keeping all other parameters constant. At the test conditions the pressure reduction $(\mathrm{a})$ across the turbine was approximately $85 \%$. These scaling results are shown as the curve in Figure 4.6.

Again using the scaling relationships, Figure 4.7 was derived to show the effect of changing working fluids. The output power increases with the increasing molecular weight of the fluid. Here, with a working fluid inlet temperature of $600^{\circ} \mathrm{F}$ and in let pressure of 820 psia, Fluorinol-85 shows about a $25 \%$ increase in power output above that achievable with air.

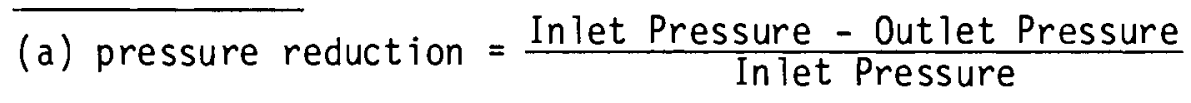




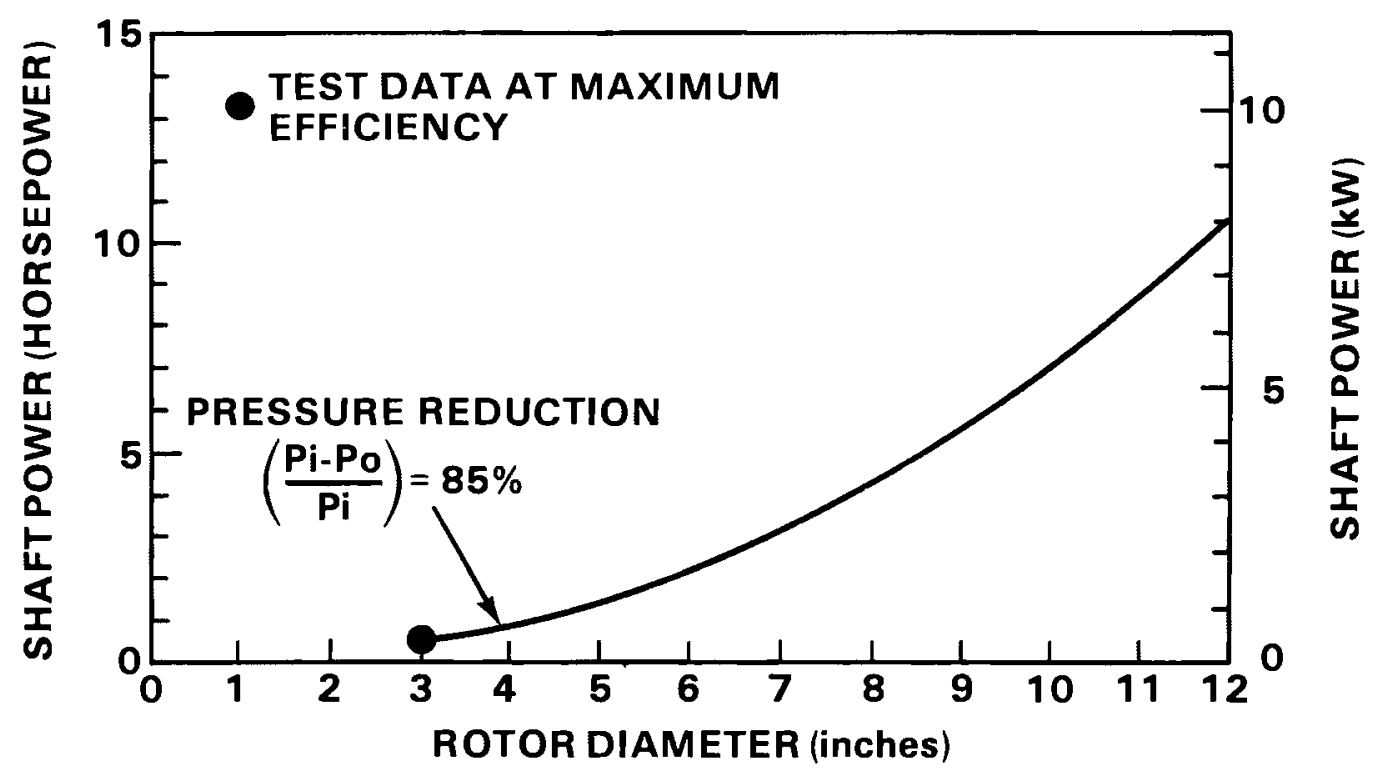

FIGURE 4.6. Turbine Performance Versus Diameter 


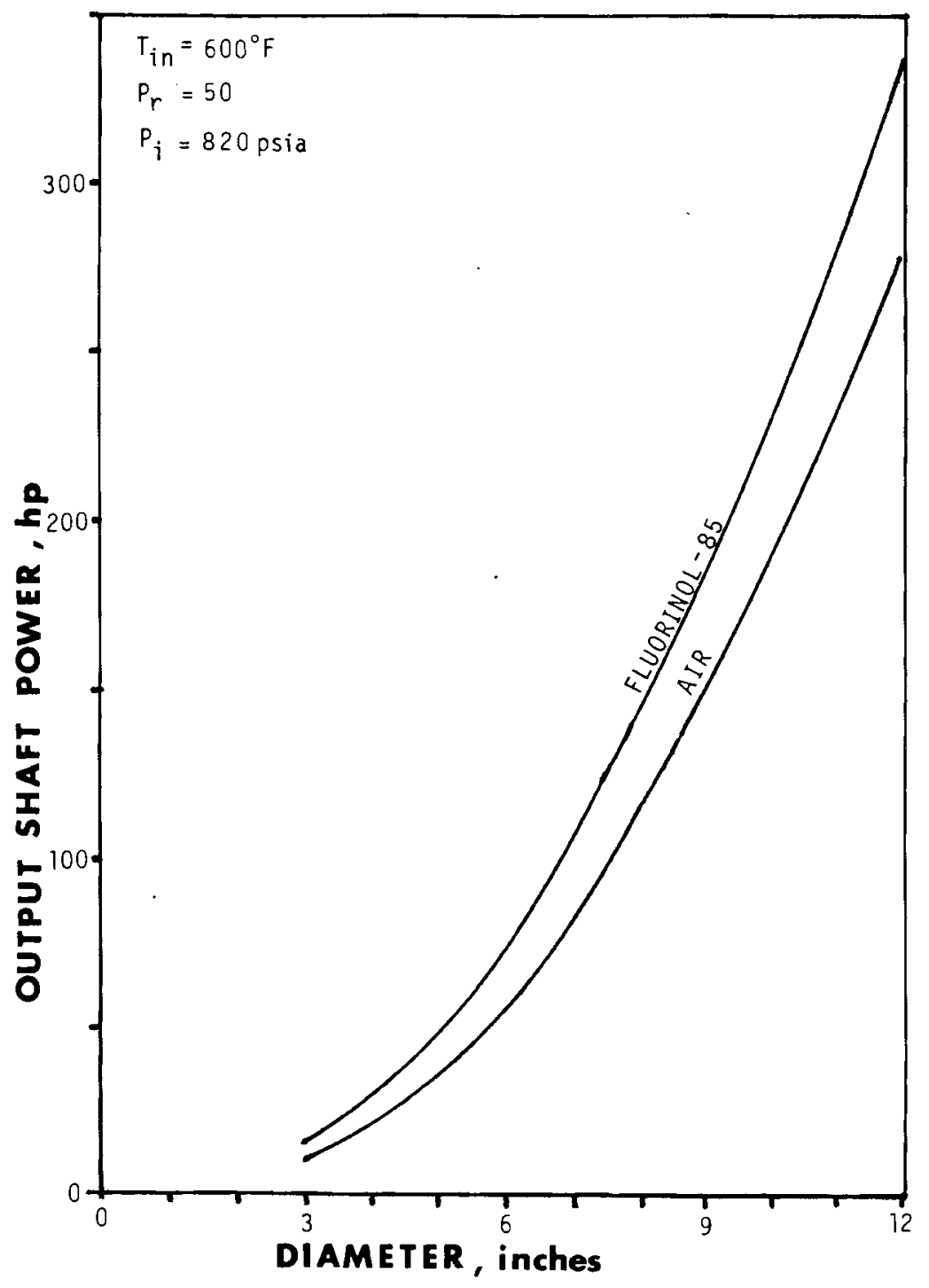

FIGURE 4.7. Output Power with Organic Working Fluid 


\subsection{COST ANALYSIS AND MARKET EVALUATION}

This section analyzes the manufacturing cost of the bladeless turbine and presents an analysis of the potential of the turbine to compete with other commercial or prototype turbines in similar applications. Candidate applications suggested by JGI include the use of the bladeless turbine in a Rankine cycle to generate shaft power to operate a compressor, pump or generator or as a direct expansion device for hot waste gases. The Rankine cycle applications are targeted for waste heat recovery or for solar thermal applications. Suggested sources of waste heat include engine exhausts from trucks, buses and marine vehicles as well as stationary power plants, and industrial reject heat.

The analysis of the cost of the turbine at various diameters is based on a manufacturing scenario and cost estimate for the three-inch diameter turbine that was provided by JGI. The analysis of the market potential of the turbine is focused on its potential use as an expander in an organic Rankine cycle (ORC). An overview of the current status of ORC development is presented along with an assessment of the potential market for ORC systems in general. The bladeless turbine is compared to other expanders that have been developed for ORC application.

\subsection{TURBINE COST ESTIMATE}

Cost estimates provided by JGI for the three-inch prototype turbine and the expected manufacturing scenario were used to extrapolate costs to other turbine diameters. These costs were used as a favorable, "best case" assumption. JGI estimates a cost of about $\$ 300$ for the three-inch prototype. JGI estimates that the cost of the three-inch turbine, manufactured in quantities of 1000 units/year, is about $\$ 140$. At a production rate of 5000 units/year the estimated cost is expected to be about $\$ 70$ per turbine. These costs are somewhat lower than the actual selling price would likely be since this cost does not include selling and distribution costs and profit.

These costs are based on fabaricating all turbine components, with the exception of the high speed bearings and the 0-rings. The 0-rings and bearings 
are purchased off-the-shelf items and are installed during the fabrication process.

Turbine components will be fabricated from solid stock stainless steel or aluminum depending on compatibility of the material with the working fluid and the cycle temperature. In most cases, stainless steel will be required because aluminum is not typically compatible with the organic working fluids considered for ORC systems. (9)

The total machining time and the cost of each component, as estimated by JGI, are listed in Table 5.1 for a production volume of 1000 units per year. The cost includes direct labor charges, direct materials, and amortized equipment costs. Fabrication would be performed by a skilled worker. About 35\% of the turbine cost is labor-related and $65 \%$ is materials-related.

The cost of the turbine was scaled to other diameters using the following relationship:

$$
\cos _{B}=\cos _{A}\left(\frac{P_{B}}{P_{A}}\right)^{x}
$$

where $P$ is the turbine shaft power.

The exponent $X$ was assumed to be 1.5 . Figure 5.1 shows the costs extrapolated to other diameters for both levels of production.

TABLE 5.1. Turbine Machine Time and Cost

\begin{tabular}{|c|c|c|}
\hline Component & $\begin{array}{c}\text { Machine Time } \\
\text { (minutes) }\end{array}$ & Cost $(\$)$ \\
\hline Rotor & 30 & 17.50 \\
\hline Face Plate & 60 & 19.50 \\
\hline Manifold & 30 & 18.60 \\
\hline \multirow[t]{2}{*}{ Distribution Chamber } & 60 & $\underline{21.30}$ \\
\hline & 180 & 77.00 \\
\hline High Speed Bearings & & 60.00 \\
\hline \multirow[t]{2}{*}{$0-$ Rings } & & 3.00 \\
\hline & TOTAL & $\$ 140.00$ \\
\hline
\end{tabular}




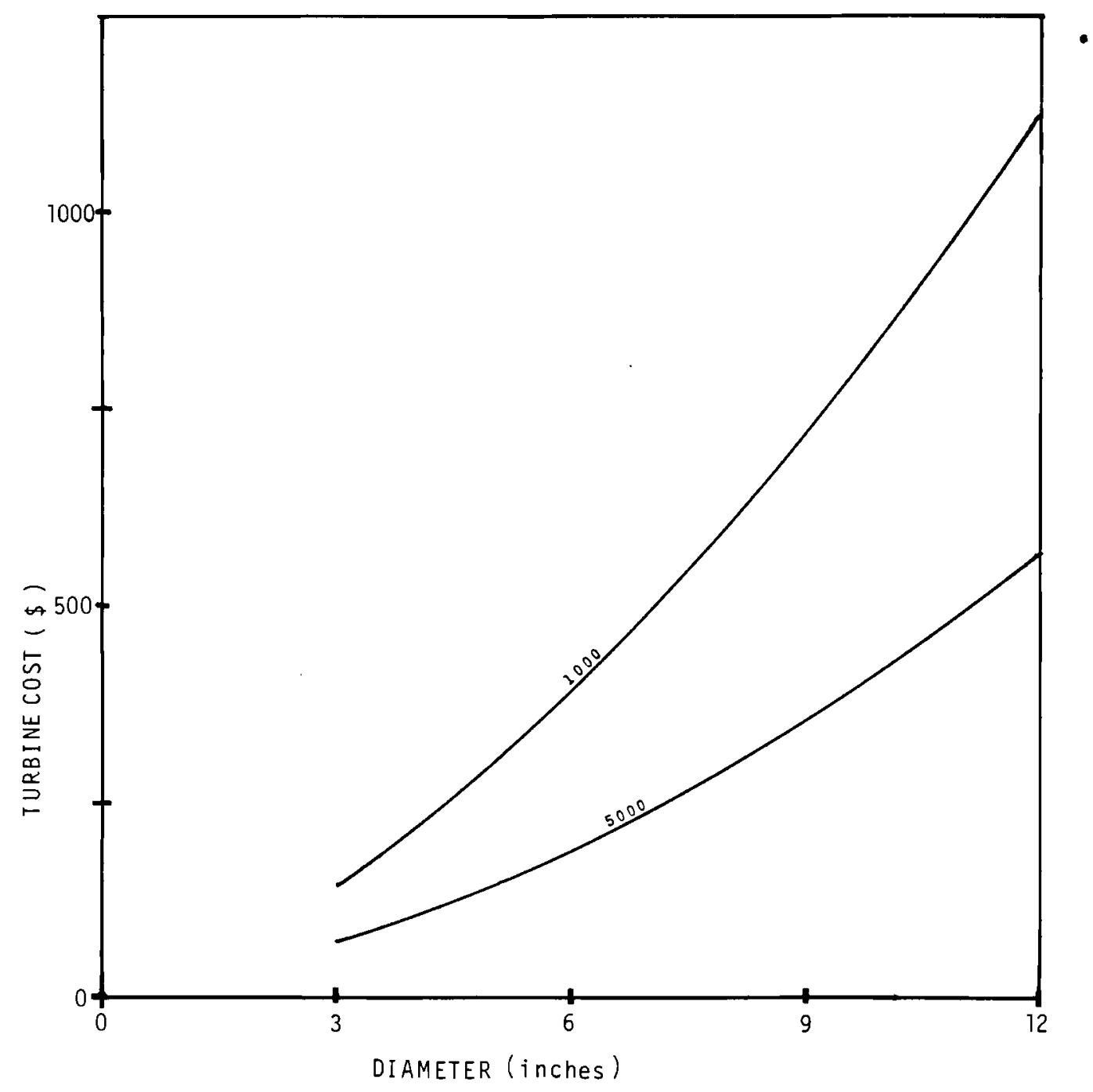

FIGURE 5.1. Turbine Cost as a Function of Rotor Diameter

The open-raceway bearings purchased for testing cost about $\$ 50$ each. Since these bearings did not demonstrate the reliability needed for long-term, high-speed operation, it is likely that more expensive bearings should be used. In view of the bearing costs, the costs shown in Figure 5.1 are considered optimistic. 


\subsection{ORGANIC RANKINE CYCLE TECHNOLOGY}

This subsection provides a brief overview of ORC system technology. An illustration of an organic Rankine cycle is shown in Figure 5.2. The system consists of the following components:

- a waste heat boiler, which transfers heat from the waste heat source to the working fluid;

- an expander, which converts thermal energy to shaft power;

- a condenser that consists of a water cooled heat exchanger;

- a feed pump; and

- a regenerator.

Basically, the organic Rankine cycle converts heat energy to mechanical energy by evaporating a pressurized working fluid and then expanding the vapor through an expansion device to produce shaft power. Following expansion, the working fluid is condensed and recycled to the boiler.

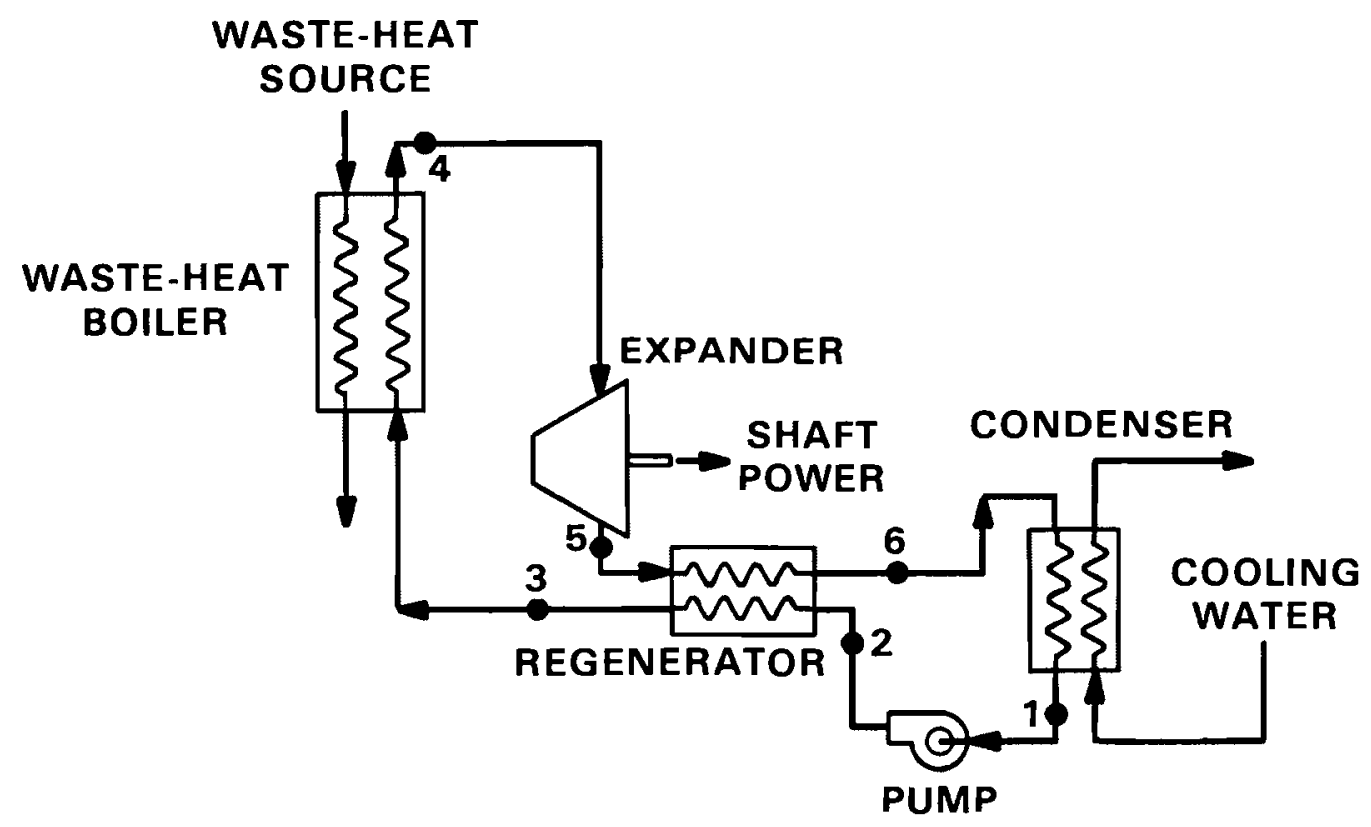

FIGURE 5.2. Rankine Cycle Flowchart 
The temperature-enthalpy diagram corresponding to the ORC schematic is shown in Figure 5.3. The working fluid exits the condenser as a liquid at state 1 and is pressurized by the feed pump to state 2 . The liquid is preheated to state 3 in the regenerator by heat exchange with the expander exhaust. The fluid is vaporized and superheated to state 4 in the waste heat boiler. Then, the pressurized vapor is expanded to state 5 producing mechanical energy, (state $5_{s}$ represents an ideal, isentropic expansion). The fluid exhausted from the expander is precooled to state 6 in the regenerator prior to entering the condenser.

Over the range of temperatures at which application of ORC systems is considered practical (about 150 to $800^{\circ} \mathrm{F}$ ), ideal ORC efficiencies range from about 12 to $38 \%$. (10) Ideal ORC efficiency is shown as a function of peak cycle temperature in Figure 5.4. For comparison, Carnot efficiency is also plotted versus temperature in the figure. Actual Rankine cycle efficiencies are lower than the ideal efficiencies due to the irreversibility of actual thermodynamic processes and to both mechanical losses and parasitic power requirements. ORC efficiencies of about 10 to $20 \%$ have been attained in industrial waste heat recovery applications. (9)

The efficiency of the expander, to a great extent, determines the actual thermal efficiency of the system. Results of demonstrations by a number of

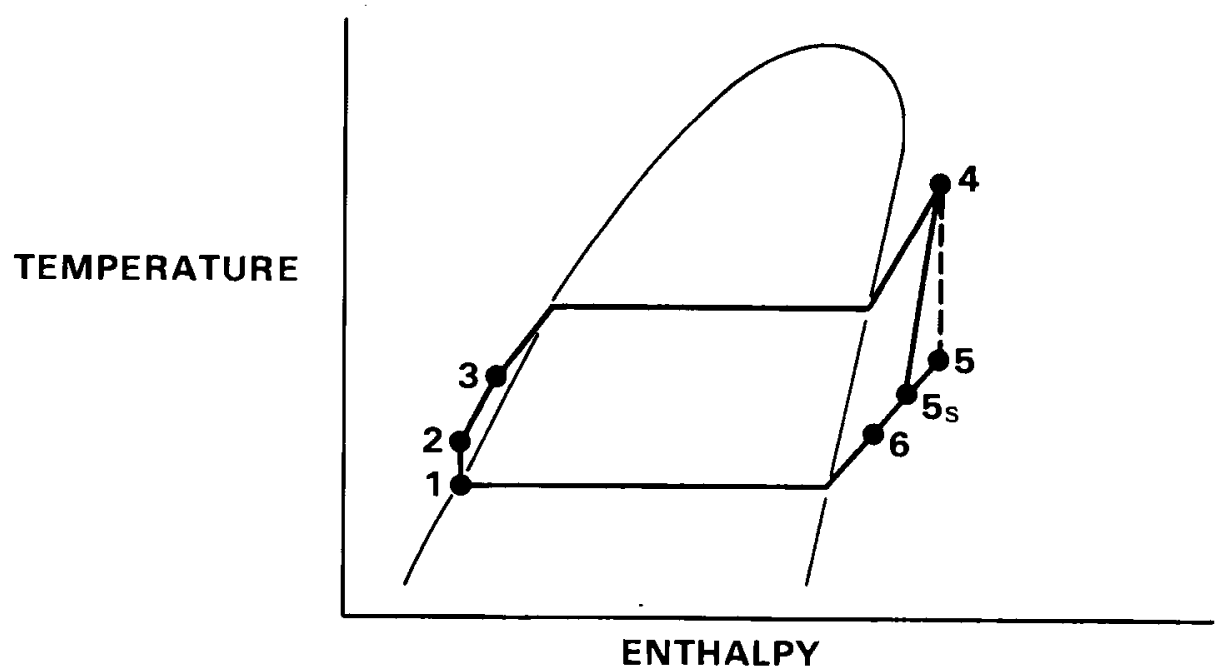

FIGURE 5.3. Rankine Cycle Temperature-Enthalpy Diagram 


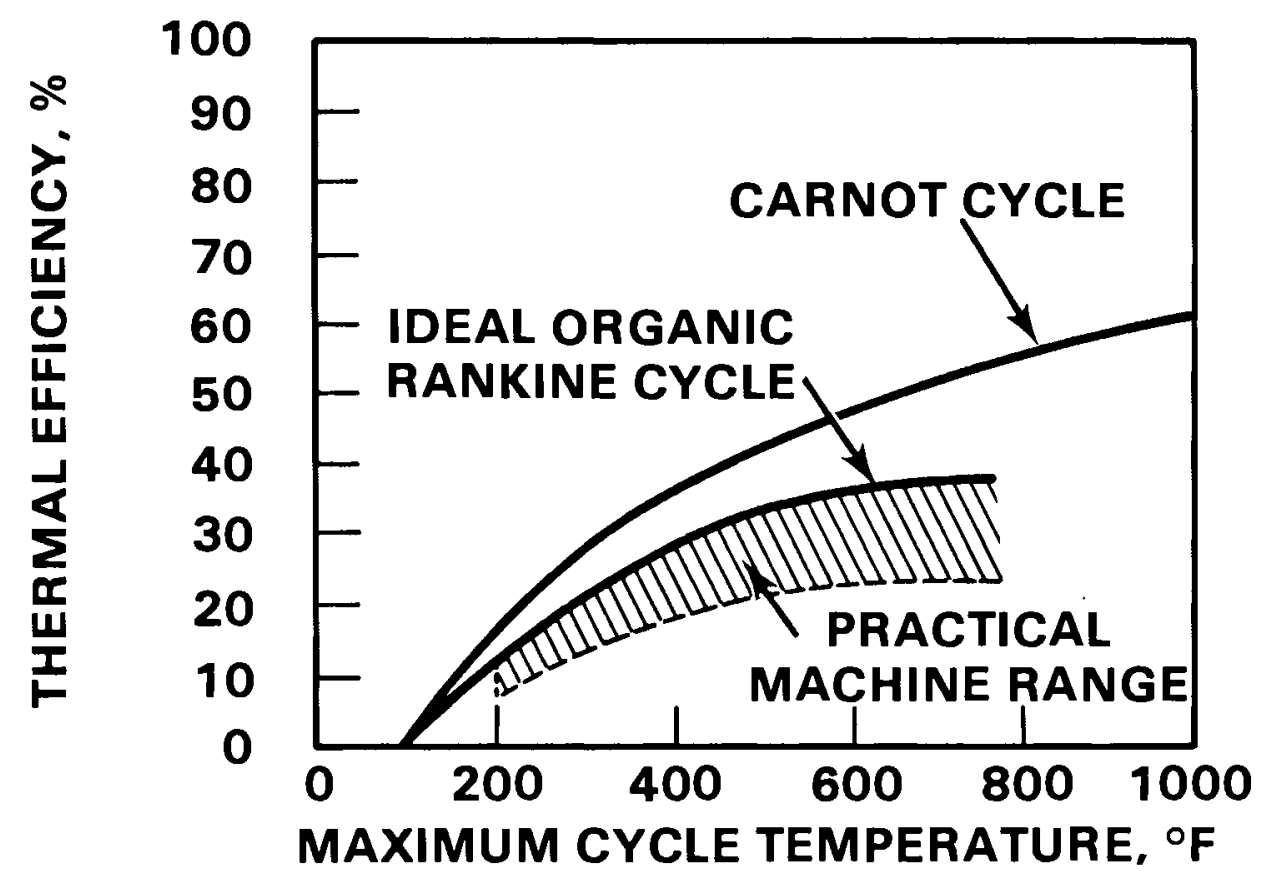

FIGURE 5.4. Theoretical Rankine Cycle Efficiency as a Function of Temperature

firms indicate that the following component efficiencies are achievable with current technologies: (11)

- Expander efficiency, 70 to $85 \%$;

- Feed pump efficiency, 70 to $93 \%$; and

- Waste heat boiler, regenerator, condenser, $90 \%$.

The high end of the range for the expander and feed pump correspond to larger systems where phenomena such as turbine clearance losses do not dominate system performance.

Most of the components of an ORC are standard commercial items with the exception of the expander. A number of types of expanders have been proposed for use in ORC systems. These include reciprocating engines, turbines and positive-displacement, rotary devices. Turbines are generally considered most appropriate for large ORC systems, whereas postive-displacement devices have many advantages for smaller units. (11) 
The largest components are the heat exchangers that serve as the waste heat boiler, regenerator and condenser. The heat exchangers tend to dominate system costs, accounting for 30 to $40 \%$ of the system costs. $(9,12)$ The expander accounts for about $20 \%$ of the system capital cost.

\subsection{ORGANIC RANKINE CYCLE MARKET}

This section identifies the major firms involved in ORC development and manufacture, summarizes their efforts in this field, and assesses the market potential for ORC systems.

A number of firms have developed organic Rankine cycle engines for a variety of applications. These applications include bottoming cycles for engines, industrial waste heat recovery, and solar and geothermal applications. Much of the development and demonstration effort in the United States has been funded by the Department of Energy as a part of solar, geothermal or conservation programs. (11)

A list of some of the most active domestic firms, along with some key parameters are shown in Table 5.2. As shown in the table, the size of the prototype ORC systems have varied from less than $3 \mathrm{~kW}$ to as large as 2.5 Megawatts ( 3 to $3550 \mathrm{hp}$ ). In general, both the expander efficiency and the overall ORC efficiency increase with size. However, it is also evident that high expander efficiencies are achievable at the smaller sizes. Most notable is the G.E. rotary vane expander with an efficiency of 84 to $85 \%$ at three horsepower.

A number of foreign firms have been active in ORC development and manufacture. Japanese government and industry, driven by dependence on energy imports, have been involved in ORC research and testing for more than ten years. Their focus has been on ORC development for waste heat recovery, solar and geothermal applications. (13) Sofretes, a firm in France, is now producing a limited number of ORC units for solar water pumping. (11) Ormat, in Israel, has been manufacturing smaller ORC engines $(1-\mathrm{kW})$ for more than 10 years. (11) In both of these latter two cases, the ORC systems are marketed primarily for remote applications and for developing countries. 
TABLE 5.2. Organic Rankine Cycle Demonstration Projects

\begin{tabular}{|c|c|c|c|c|c|}
\hline Developer & $\begin{array}{c}\text { Power } \\
\mathrm{kW}\end{array}$ & $\begin{array}{l}\text { Expander } \\
\text { Type }\end{array}$ & $\begin{array}{c}\text { Expander } \\
\text { Efficiency, } \%\end{array}$ & $\begin{array}{c}\text { ORC } \\
\text { Efficiency } \%\end{array}$ & Application \\
\hline AiResearch & 10 & radial inflow turbine & 80 & $10-25$ & solar \& waste heat \\
\hline Barber-Nichols & 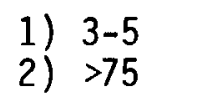 & radial inflow turbine & $\begin{array}{l}\text { 1) } 60-65 \\
\text { 2) } 80\end{array}$ & $6-10$ & solar $A / C$ \\
\hline General Elec. & $\begin{array}{l}\text { 1) } 2,3 \\
\text { 2) } 7 \\
\text { 3) } 30\end{array}$ & rotary vane expander & $84-85$ & $\begin{array}{ll}\text { 1) } & 8-10 \\
\text { 2) } & 14-15 \\
\text { 3) } & 16.5\end{array}$ & $\begin{array}{l}\text { 1) Solar } A / C \\
\text { 2) Solar } A / C \\
\text { 3) diesel truck }\end{array}$ \\
\hline $\begin{array}{l}\text { Mechanical } \\
\text { Technology, Inc }\end{array}$ & $1000-2500$ & radial inflow turbine & $>70$ & $12-15$ & $\begin{array}{l}\text { waste heat } \\
\text { and OTEC }\end{array}$ \\
\hline Sundstrand & 750 & axial flow turbine & $75-76$ & 20 & $\begin{array}{l}\text { waste heat, indus- } \\
\text { trial \& diesel }\end{array}$ \\
\hline $\begin{array}{l}\text { Thermo- } \\
\text { Electron }\end{array}$ & $\begin{array}{l}\text { 1) } 35 \\
\text { 2) } 75 \\
\text { 3) } 450\end{array}$ & axial flow turbine & $\begin{array}{l}\text { 1) } 72 \\
\text { 2) } 76 \\
\text { 3) } 81\end{array}$ & $\begin{array}{l}\text { 1) } 18 \\
\text { 2) } 19-20 \\
\text { 3) } 20\end{array}$ & $\begin{array}{l}\text { 1) diese } 1 \text { truck } \\
\text { 2) diese } 1 \text { truck } \\
\text { 3) diesel generator }\end{array}$ \\
\hline
\end{tabular}


None of the domestic or foreign ORC systems can be considered to be fully commercialized. Cost reductions due to learning and to economies of scale that are associated with large volume production have not been realized due to low demand for the product. Figure 5.5 presents current and projected costs of ORC systems at 1982 price levels. Costs were obtained from the domestic developers of ORC systems at current production levels and for 10,000 units per year.

Current costs reflect the fact that a significant portion of the cost is for development engineering rather than fabrication. The projected costs, at a production rate of 10,000 units per year, are lower for a number of reasons. First, moving from producing one-of-a-kind to standardized components will lower costs by amortizing the engineering and development costs over a larger number of units. In the same manner, fabrication costs will be reduced as equipment and overhead costs are spread over a larger number of units. Lastly, costs will be reduced as labor hours decrease along a learning curve.

In a study for the Department of Energy, Resource Planning Associates (RPA) identified a total technical market potential for ORC application in the

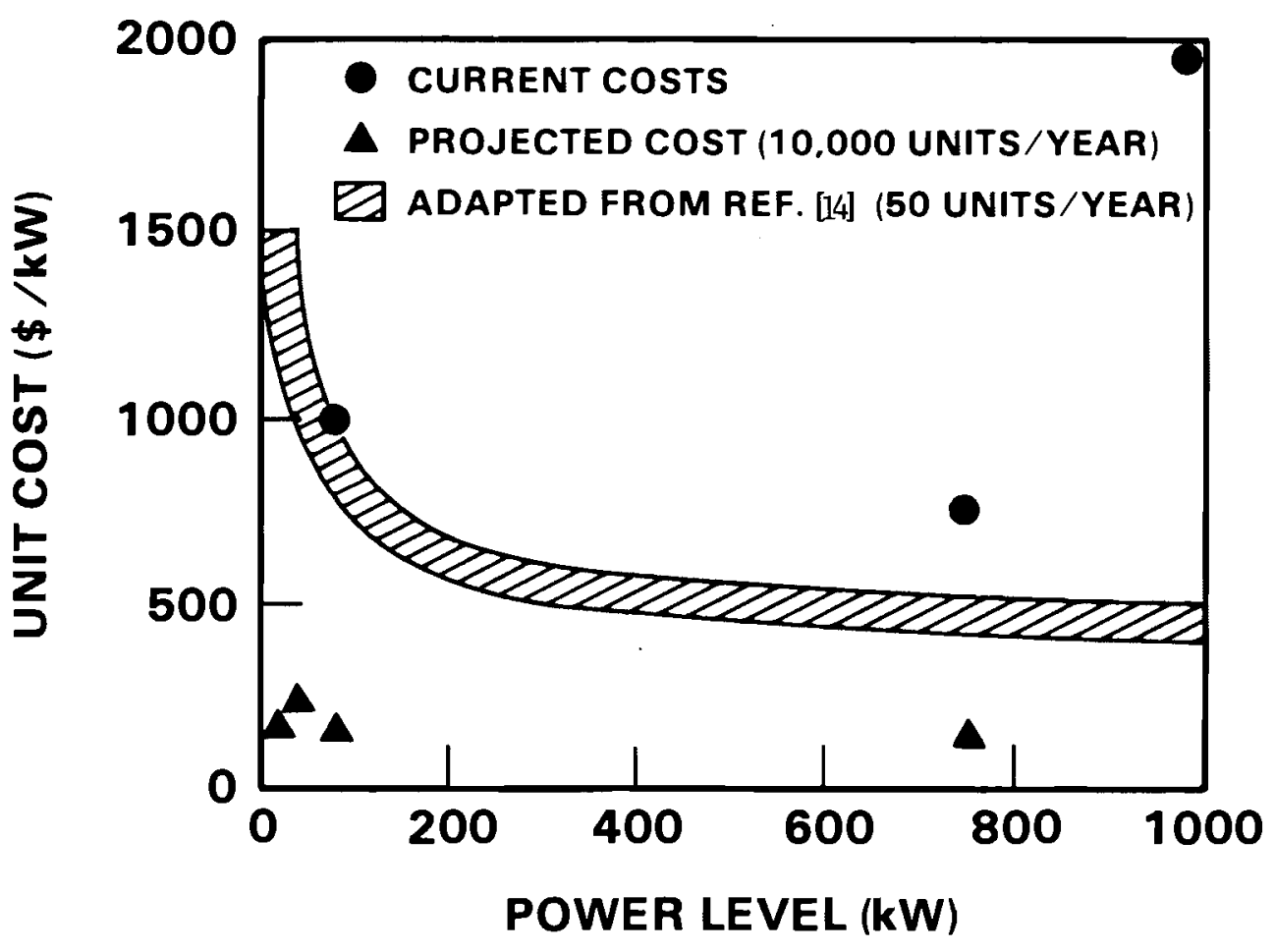

FIGURE 5.5. ORC System costs 
industrial sector of $3220.5 \mathrm{MW}\left(129,946 \mathrm{BPDE}^{(\mathrm{a})}\right) .{ }^{(15)}$ Using industryspecific values for expected ORC utilization, cost of electricity, ORC insta11ed cost, and required rate of return on investment, RPA estimated the total economic market potential at $64.4 \%$ of the technical potential or 2,072.4 MW $(83,621 \mathrm{BPDE}) .(15)$

Although the technical and market potential of ORC systems appear to be very promising, a number of barriers to market penetration are evident. These barriers are summarized in Table 5.3. Industry is reluctant to invest in equipment for which reliability and operating cost have not been fully established. Some industries are skeptical about dealing with high-speed, precision equipment and toxic or flammable working fluids. Industries that already have operating experience with this type of equipment and chemicals do not consider this a barrier.

Some industries are already adopting waste heat recovery technologies that utilize waste heat in the same range at which ORC systems could be applied. For example, feedstock preheating in the chemical industry uses waste heat at temperatures of 150 to $300^{\circ} \mathrm{F} .{ }^{(14)}$ In the primary metals industries, ORC systems would have to compete with steam generation, and preheating of combustion air and charge materials. For ORC adoption, the industry must have a need

(a) Barrels per day equivalent

TABLE 5.3. Barriers to ORC Market Penetration $(14,15)$

- Lack of operating history

- system reliability

- operating costs

- toxic and flammable working fluids

- Competing technologies in certain temperature ranges

- Special material requirements

- Interest in reducing energy input rather than recovering waste energy

- New systems favored over retrofits because of lower costs

- Limited space available for retrofits 
for on-site power generation that does not compete with alternative uses for the waste heat.

At higher temperatures, and due to constituents of some waste heat streams, special materials will be required for the waste heat boiler. Because this is one of the major cost components of an ORC, a material change could significantly impact the total cost.

Competing with all waste heat recovery technologies is the growing interest in reducing energy usage. If more efficient process equipment is available or more efficient operating techniques, industry may prefer to implement these to reduce the amount of waste heat rather than try to recapture it.

Another potential barrier is the fact that new systems are less expensive than retrofitted systems. The market potential for new systems, however, is significantly smaller than that for retrofits since investment in new plants and equipment represents only a very small fraction of the existing stock. In some cases, retrofitting may be prohibited not only by the cost, but also by the space available. This is thought to be particularly true for the older, congested plants in the primary metals industry. (15)

\subsection{MARKET POTENTIAL OF BLADELESS TURBINE}

This section discusses the expected market potential of the bladeless turbine in organic Rankine cycle applications and analyzes the potential of the specific applications proposed by JGI. These applications are heat recovery from the exhaust of a gasoline internal combustion engine to supercharge a rotary screw air compressor and heat recovery from the exhaust of an internal combustion engine to turbo charge the engine itself.

In order to evaluate the potential of the bladeless turbine in an ORC system, it was first necessary to estimate the overall cost of the ORC. The turbine cost was assumed to be about $20 \%$ of the capital cost of the ORC. (12) This is a highly favorable assumption in view of two considerations. First, because of the simplicity of the turbine it is less expensive than other turbines and would therefore likely represent a smaller percentage of the total ORC cost than other systems. Secondly, due to the low efficiency of the expander, the associated heat exchangers and pumps would have to be larger than 
those systems with more efficient expanders in order to produce a given output. Thus, the $20 \%$ assumption is used as a "best case" scenario. Other assumptions used to estimate the installed cost of an ORC system using a Gamell expander include the following:

- marketing, administration and engineering

$$
\begin{aligned}
& 6 \% \text { of total capital }(9) \\
& 6 \% \text { of total capital }(9) \\
& 150 \% \text { of total capital }
\end{aligned}
$$

- profit

The installed ORC system cost was divided by the shaft power produced by the turbine to yield $\$ / \mathrm{kW}$ figures for diameters up to 12 -inches. The turbine shaft power at each diameter for a turbine with a Fluorinol-85 working fluid was presented earlier in Figure 4.8. At an annual production rate of 1000 units per year, the unit costs averaged about $\$ 110 / \mathrm{kW}$ at a diameter of five inches. At a production rate of 5000 units/year, this average unit cost was $\$ 60 / \mathrm{kW}$. The current costs of ORC systems utilizing the 5 -inch bladeless turbine would be about $\$ 250 / \mathrm{kW}$. Comparing these figures with those presented earlier in Figure 5.5 indicates that the Game 11 turbine ORC may have a cost advantage over some of the other ORC systems at production volumes of 5000 units per year. Caution must be used, however, in comparing these figures since they have not all been derived on the same basis. The current costs presented in Figure 5.5 are probably the most accurate since they are based on actual experience. The projected costs in Figure 5.5 and those for the Game 11 turbine are highly uncertain and depend to a large extent on an expanding market.

Of the barriers to market penetration presented earlier in Table 5.3, two will likely impact the Gamell system more than other prototype systems. The first of these is its lack of operating history. Because of the high rotational speeds experienced by the turbine, the reliability question becomes an important issue. Testing at PNL indicated that the bearings currently proposed for the prototype are inadequate for high speed operation. Also the shaft failure experienced after 50 hours of testing may be indicative of problems that could be encountered during actual operations. The other impediment that may affect acceptance of the Gamell turbine is the limited space available for retrofits. At a given capacity, the Gamell system would have to be larger than other proposed systems due to its lower efficiency. 
The specific applications for the bladeless turbine, proposed by JGI are shown in Figures 5.6 and 5.7. Figure 5.6 shows an organic Rankine cycle recovering heat from the exhaust of an internal combustion engine. The bladeless turbine provides shaft power to operate a compressor which turbocharges the engine. The expected load factor (percent of year ORC is operating) is about 40 percent.

Figure 5.7 also shows the organic Rankine cycle recovering heat from the exhaust of an internal combustion engine. This application is intended for onsite power generation where the power is used to operate compressors, such as in mining operations. In this case, the bladeless turbine generates shaft power to operate a compressor which "pre-compresses" air delivered to a rotary screw air compressor. The expected load factor for this ORC is about 25\%.

The operating temperatures, pressures and flow rates are the same in both cases. The working fluid is Fluorinol-85 and the peak cycle temperature is $600^{\circ} \mathrm{F}$ at a pressure of $820 \mathrm{psia}$. The diameter of the turbine in this application is 4.88 inches.

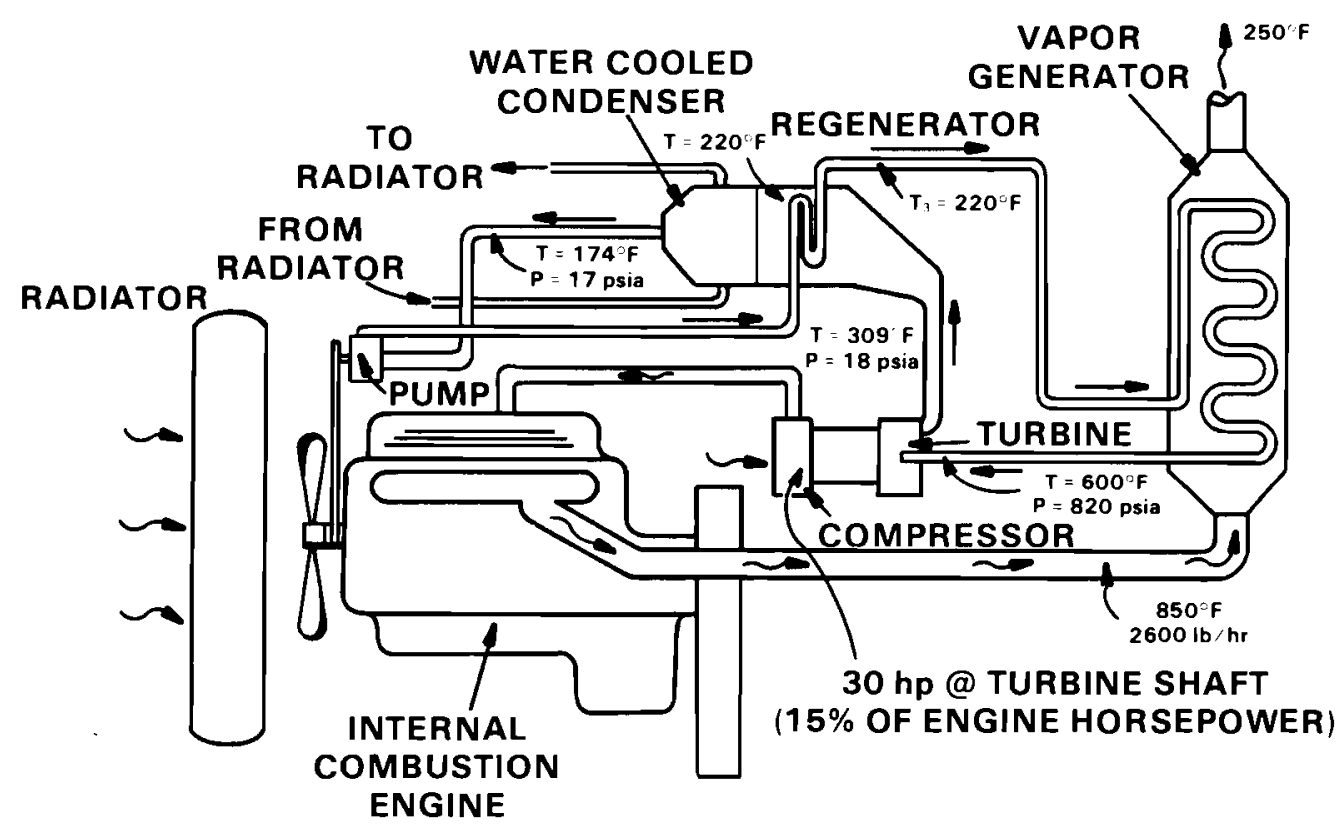

FIGURE 5.6. Rankine Cycle Turbocharging System 


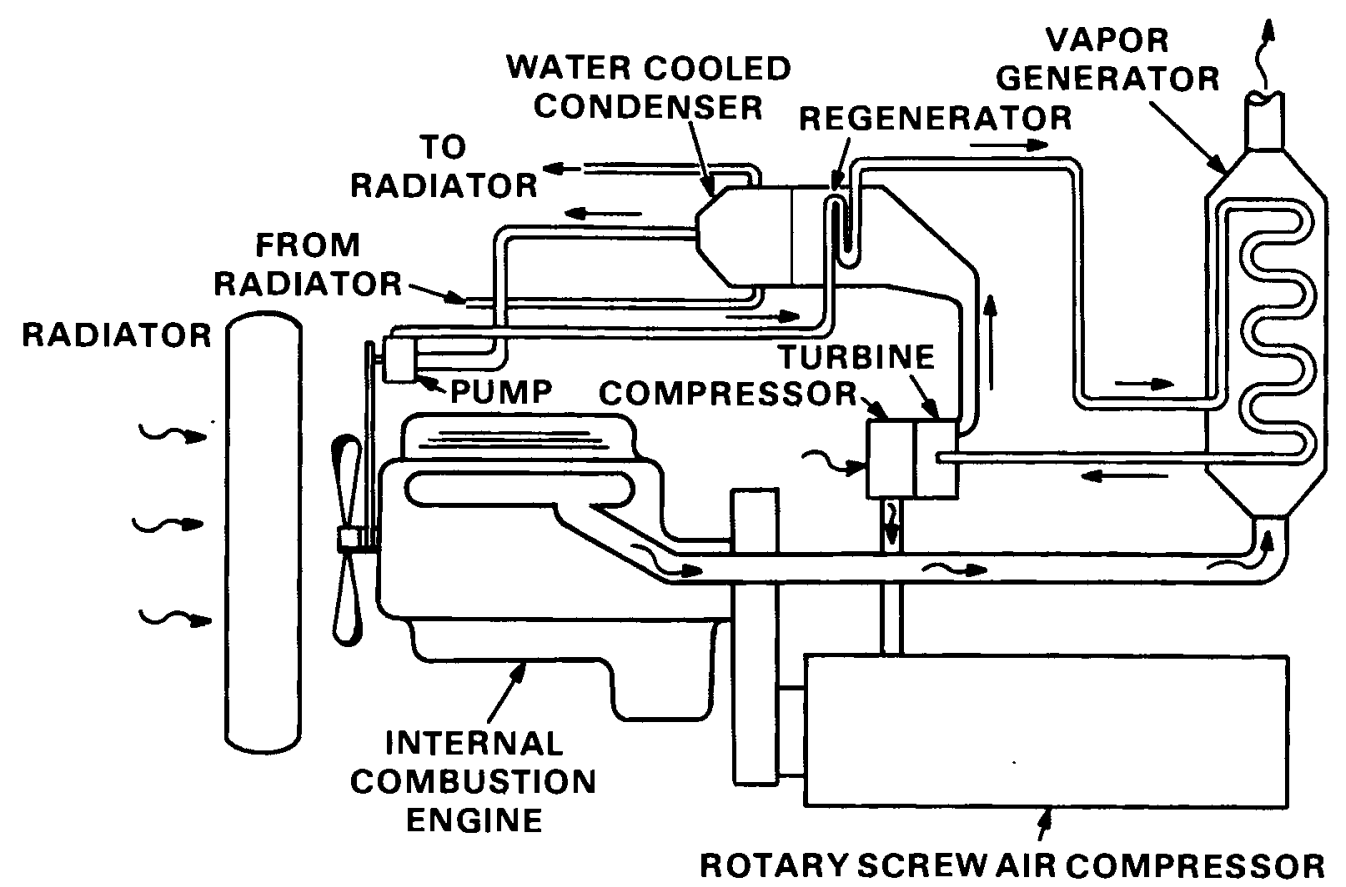

FIGURE 5.7. Heat Recovery to Supercharge Air Compressor

Using the efficiency scaling relationship presented in Section 4.0, the peak turbine efficiency for this application was calculated to be about $30 \%$. The required effectiveness of the vapor generator must be greater than $93 \%$ in order for the $30 \mathrm{hp}$ to be produced. Once the parasitic pumping power is accounted for, the net output of the cycle is about $27 \mathrm{hp}$. If a vapor generator effectiveness of one, corresponding to an infinite heat exchange area, is assumed, the turbine shaft power generated is $32 \mathrm{hp}$, with the net cycle horsepower slightly less than 30 . In both cases, the relatively large heat transfer areas required would result in relatively high costs for the system. The size of the vapor generator may preclude the use of this system in mobile applications.

The overall cycle efficiency with a heat exchanger effectiveness of one is about 19\%. As the effectiveness of the vapor generator is dropped to more realistic values, the overall cycle efficiency will drop as well. At a net cycle output of $27 \mathrm{hp}$ (effectiveness equal to $93.8 \%$ ) the overall cycle efficiency is dropped to $17.6 \%$. 


\section{REFERENCES}

1. Rauch, Burton. August 1979. Background and Feasibility Study of a Gamel1 Turbine for Low-Head Hydro Rehabilitation. F-C5176. Franklin Research Center, Philadelphia, PA.

2. Glassmain, A. J., ed. 1973. Turbine Design and Application. (3 volumes). NASA SP-290. National Aeronautical and Space Administration, Washington, D.C.

3. McLallin, K. L., and J. E. Haas. 1980. Experimental Performance and Analys is of 15.04-Centimeter Tip-Diameter, Radial-Inflow Turbine with Work Factor of 1.126 and Thick B lading.

4. Wark, K. 1971. Thermodynamics. McGraw-Hi11, New York, NY.

5. 01 son, R. M. 1968. Essentials of Engineering Fluid Mechanics. International Textbook Company, Scranton, PA.

6. Daily, J. W., and D. R. F. Harleman. 1973. Fluid Dynamics. AddisonWesley, Inc., Reading, MA.

7. Fox, R. W., and A. T. McDonald. 1973. Introduction to Fluid Mechanics. Wiley, New York, NY.

8. Kadambi, V., and M. Prasad. 1977. Turbomachinery Vol. 3. of An Introduction to Energy Conversion. Halsted Press Division of Wiley, New York, NY.

9. Marciniak, T. J., et a1. June 1981. Comparison of Rankine-Cycle Power Systems: Effects of Seven Working Fluids. ANL/CNSV-TM-87. Prepared for U.S. Department of Energy by Argonne National Laboratory, Argonne, IL.

10. Sternlicht, Beno. 1975. "Low-Level Heat Recovery Takes on Added Meaning as Fuel Costs Justify Investment." Power. 119(4):84-87.

11. U.S. Department of Energy. November 1979. Distributed Energy Systems: A Review of Related Technologies. DOE/PE-03871-01, Washington, D.C.

12. Barber, Robert E. 1978. "Current Costs of Solar Powered Organic Rankine Cycle Engines," Solar Energy. 20:1-6.

13. Isshiki, N. 1979. R and D on Rankine Cycle Engines in Japan. American Chemical Society.

14. Sternlicht, Beno. 1975. "The Equipment Side of Low-Level Heat Recovery," Power. 119(6):71-72. 
15. Resource Planning Associates, Inc. December 1978. Industrial Markets for Organic Rankine Bottoming Systems. Prepared for U.S. Department of Energy, Washington, D.C.

16. Nu11, Harold R. 1977. "Economics of Rankine Cycle Power Recovery from Waste Process Heat." In Proceedings of Energy Use Management International Conference, Vol. I, ed. R. A. Fazzadare. pp. 111-118. 
APPENDIX A

ROTAMETER CALIBRATION 


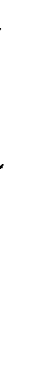




\section{APPENDIX A}

\section{ROTAMETER CALIBRATION}

Results of the calibration of two Schutte-Koerting model 61-06-692-M rotameters are presented herein. The rotameters are identified by U.S. Government property numbers L544217 and L544218. The rated capacity of each rotameter is 1.2 to 11.6 standard cubic feet of air per minute (SCFM).

\section{TEST FACILITY AND OPERATING PROCEDURE}

The calibration was performed in the facility illustrated schematically in Figure 1. Water from a process water line was filtered and its temperature measured using a Type $J$ thermocouple and a Fluke digital temperature readout. Flow rates were controlled by means of a throttling valve downstream of the rotameter. The discharge water was collected in a tank mounted on a 500 pound Fairbanks-Morse scale over a period of time measured by a Durgin-Browne electronic timer. The volumetric flow rate, gallons per minute (GPM), was calculated by dividing the weight of the water collected by the product of the elapsed time and fluid density. Conversion from GPM to SCFM was done in accordance with Instrument Society of America practice: GPM multiplied by 4.15 yields SCFM ( 1 ).

The thermocouple, temperature readout, timer, and scale are calibarated traceable to NBS standards by the Hanford Engineering Development Laboratory. Copies of the applicable documentation are included in Addenda 1-5.

\section{$\underline{\text { RESULTS }}$}

Calibration results are presented in Figures 2 and 3 in terms of flow rate, SCFM, versus rotameter scale reading, SCFM. Data from the two calibrations are tabulated in Addendum 5. Results of linear regression curve fits of the data sets are also plotted in Figures 2 and 3 . The correlation coefficients of the regression analyses for Figures 2 and 3 are 0.99929 and 0.99926 respectively, which indicate a high degree of linearity. 


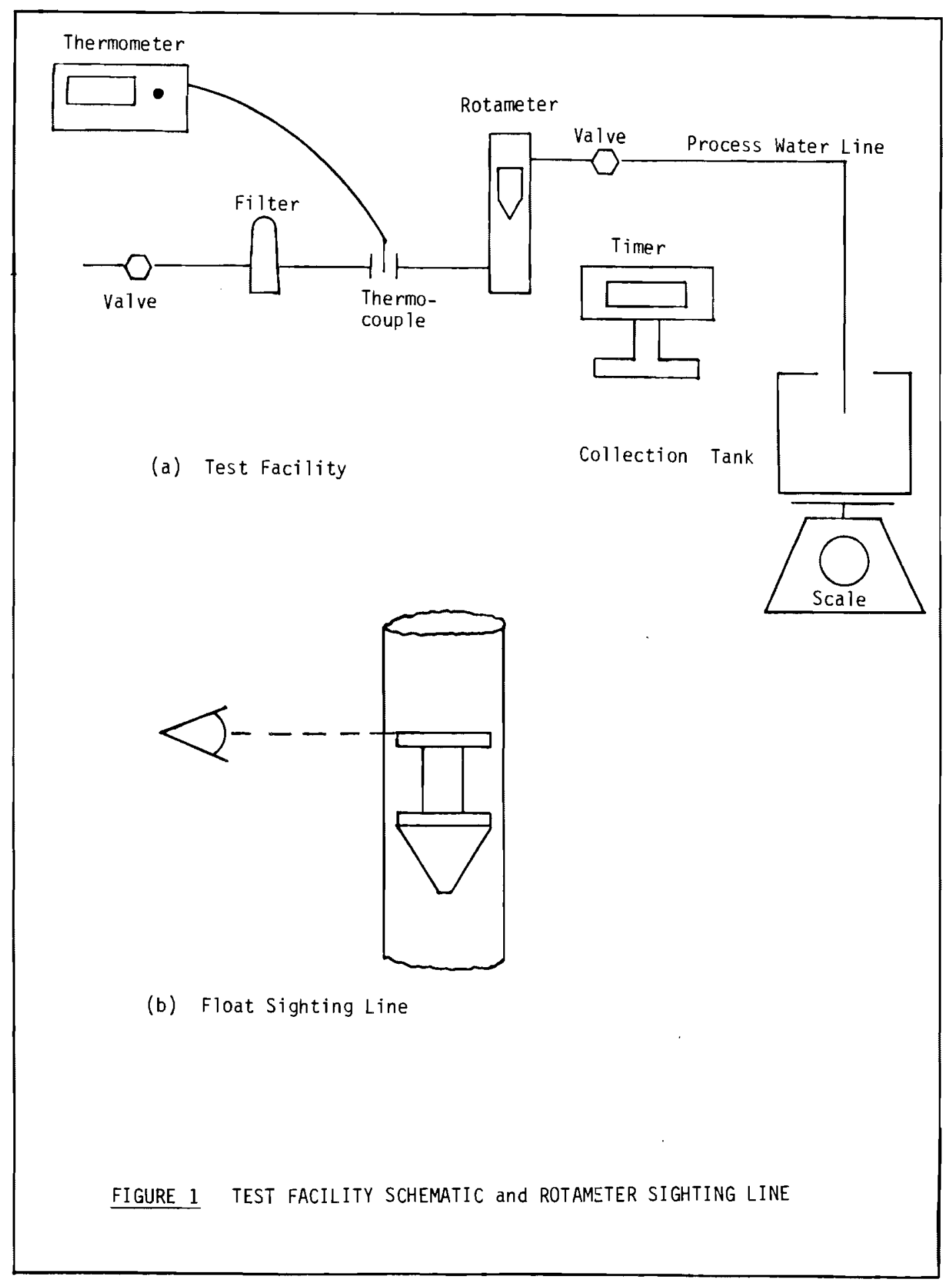

A. 2 


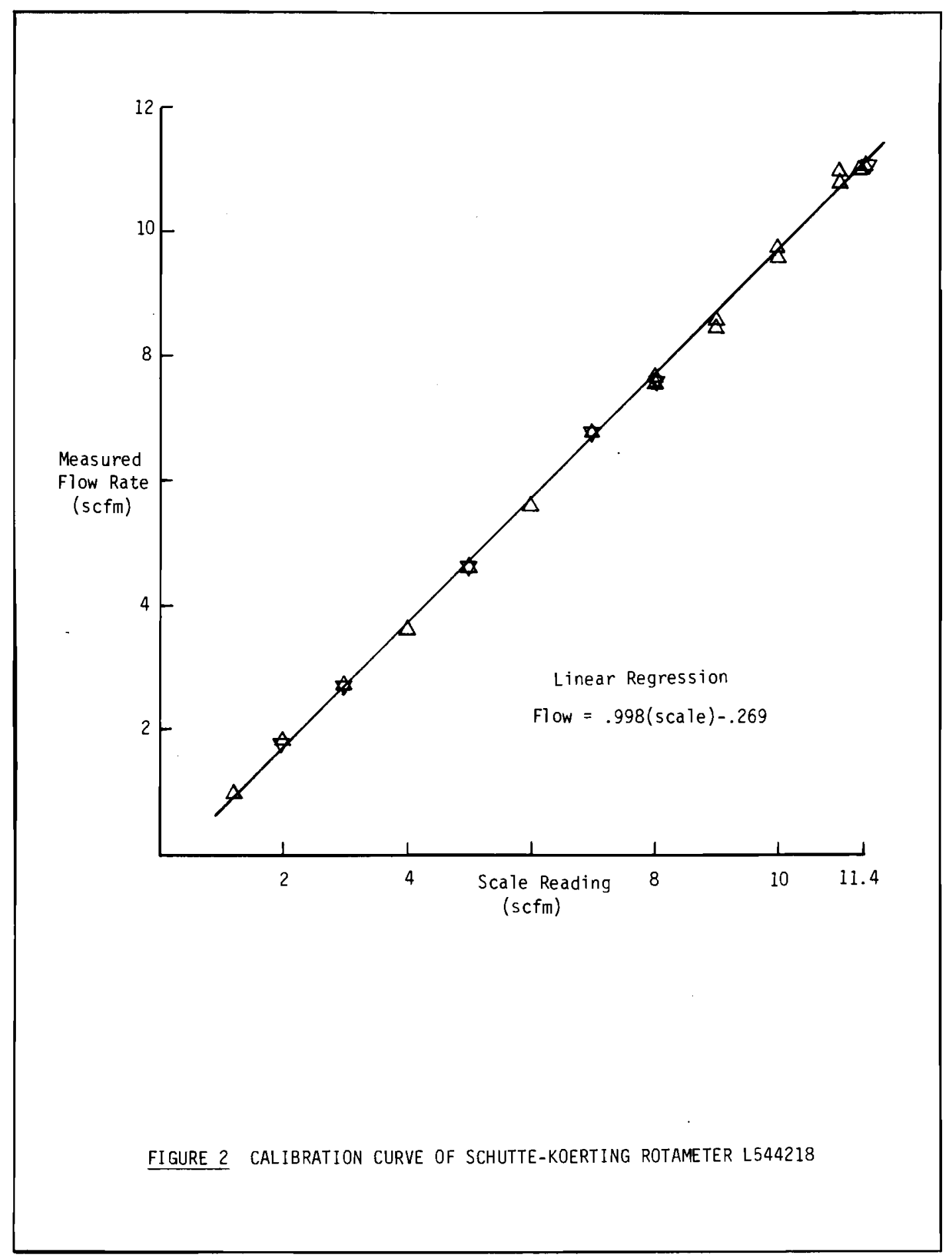

A. 3 


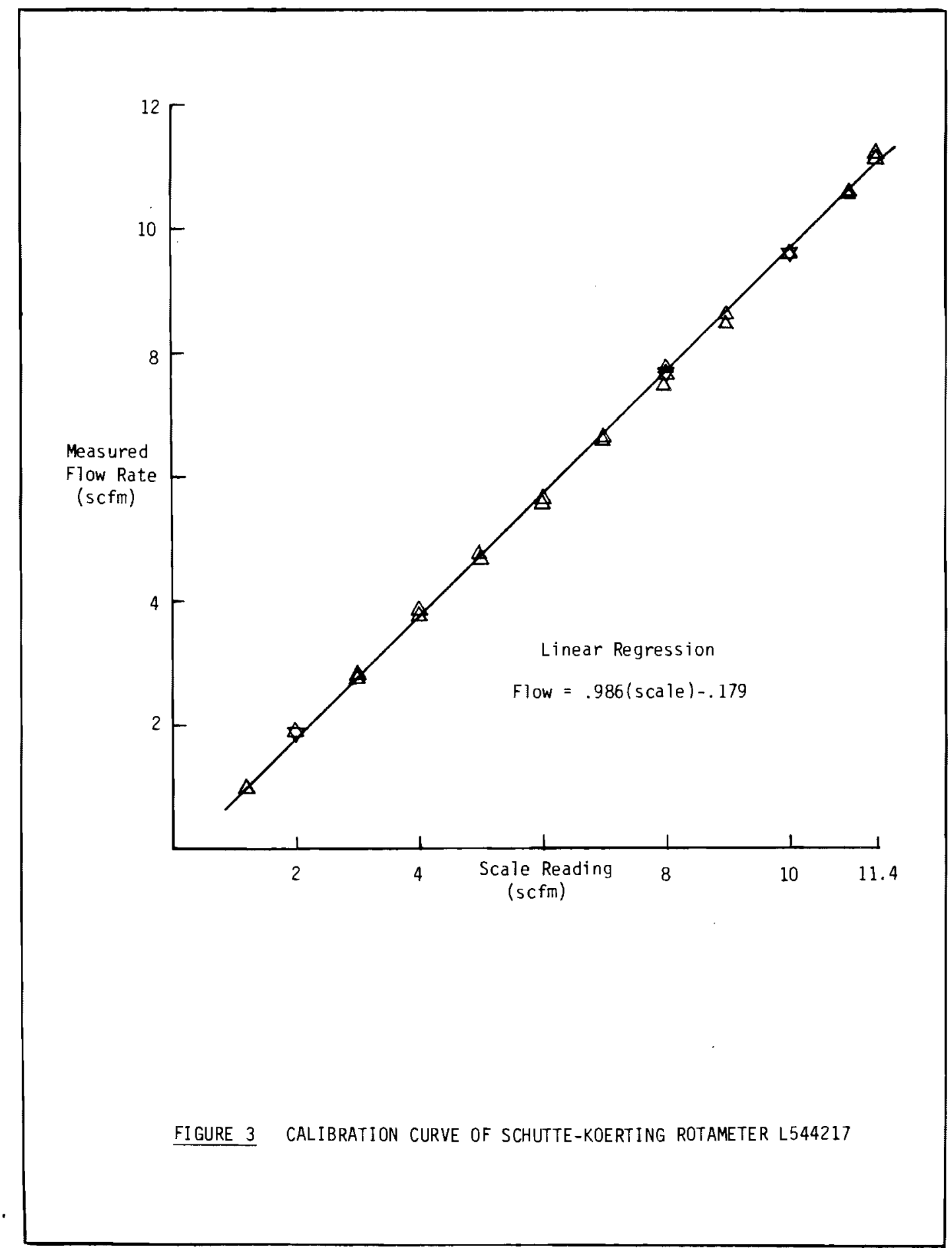

A. 4 


\section{DATA UNCERTAINTY}

An uncertainty analysis using the error and uncertainty methods of Schenck (2) was performed and is illustrated in Addendum $F$. Uncertainty values were calculated for the average results of data points A-20 through A-24 and B-20 through $B-27$. The uncertainty in the volumetric flow of each rotameter is $1.01 \%$. Furthermore, based on data points A5, A20 through A24 and B5, B20 through B27, the volumetric flow rates of $L 544218$ and $L 544217$ are repeatable to within $\pm 1.04 \%$ and $\pm 1.70 \%$ respectively. Uncertainty and repeatability summaries are presented in Tables 1 and 2 .

d

\section{REFERENCES}

1. Methods and Equipment for Calibration of Variable Area Meters (Rotameters), Instrument Society of America, July 1961.

2. Schenck, H., Theories of Engineering Experimentation. Third Edition, 1979 Hemisphere Publishing Corporation, Washington D.C. 
TABLE 1. Summary of Uncertainty per Averaged Data A20 through A24 and B20 through B27

\begin{tabular}{|c|c|c|c|}
\hline Parameter & Value & $\begin{array}{l}\text { Uncertainty } \\
\text { Interval } \\
\end{array}$ & Percent \\
\hline Temperature & $47^{\circ} \mathrm{F}$ & $\pm 1^{0} \mathrm{~F}$ & \pm 2.13 \\
\hline Time & $194.66 \mathrm{sec}$ & $\pm 0.25 \mathrm{sec}$ & \pm 0.13 \\
\hline Weight & $50 \mathrm{lbf}$ & $\pm 0.5 \mathrm{lbf}$ & \pm 1.00 \\
\hline $\begin{array}{l}\text { F low rate } \\
\text { (A20-A24) }\end{array}$ & $0.256 \mathrm{lbm} / \mathrm{sec}$ & $\begin{array}{l}+0.00258 \\
\mathrm{~T} b \mathrm{bm} / \mathrm{sec}\end{array}$ & \pm 1.01 \\
\hline $\begin{array}{l}\text { Flow rate } \\
\text { (B20-B27) }\end{array}$ & $0.257 \mathrm{lbm} / \mathrm{sec}$ & $\begin{array}{l} \pm 0.00259 \\
7 \mathrm{bm} / \mathrm{sec}\end{array}$ & \pm 1.01 \\
\hline
\end{tabular}

TABLE 2. Summary of Repeatability for Data A5, A20 through A24 and B5, B20 through B27

\begin{tabular}{|c|c|c|c|}
\hline Parameter & $\begin{array}{c}\text { Average } \\
\text { Value }\end{array}$ & $\begin{array}{l}\text { High Value } \\
\text {-Low Value }\end{array}$ & Percent \\
\hline $\begin{array}{l}\text { Flow rate } \\
\text { (A5, A20-A24) }\end{array}$ & 7.66 SCFM & 0.08 & 1.04 \\
\hline $\begin{array}{l}\text { Flow rate } \\
\text { (B5, B20-B27) }\end{array}$ & 7.66 SCFM & 1.30 & 1.70 \\
\hline
\end{tabular}




\section{ADDENDUM 1}

Rotameter Calibration Instrumentation List

\begin{tabular}{|c|c|c|c|c|}
\hline Item & $\begin{array}{c}\text { Identifying Code } \\
\text { (e.g., Serial Number) }\end{array}$ & $\begin{array}{c}\text { Calibration } \\
\text { Date }\end{array}$ & $\begin{array}{c}\text { Expiration } \\
\text { Date } \\
\end{array}$ & $\begin{array}{c}\text { Calibration } \\
\text { Reference } \\
\text { Number } \\
\end{array}$ \\
\hline $\begin{array}{l}\text { Digital timer } \\
\text { Durgin \& Browne } \\
\text { LT BX10 A }\end{array}$ & 7807 (sn) & $3-12-81$ & $3-12-82$ & $\begin{array}{l}\text { HEDL } 374-18- \\
02-002\end{array}$ \\
\hline $\begin{array}{l}500 \text { lb scale } \\
\text { Fairbanks-Morse }\end{array}$ & USA-HEW 457-698 & $3-6-81$ & $3-6-82$ & $\begin{array}{l}\text { HEDL 374-66- } \\
01-001\end{array}$ \\
\hline $\begin{array}{l}\text { Thermocoup le } \\
\text { Type J }\end{array}$ & $\# 57$ & $3-20-81$ & $3-20-82$ & HEDL 121821 \\
\hline $\begin{array}{l}\text { Fluke Digital } \\
\text { Thermometer }\end{array}$ & 0790011 (sn) & $1-20-82$ & $1-20-83$ & $\begin{array}{l}\text { HEDL 374-79- } \\
06-001\end{array}$ \\
\hline
\end{tabular}


TIMER, DIGITAL

DURGIN-BROWN LTBXTO-A

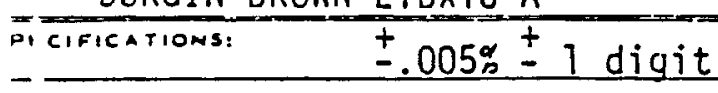

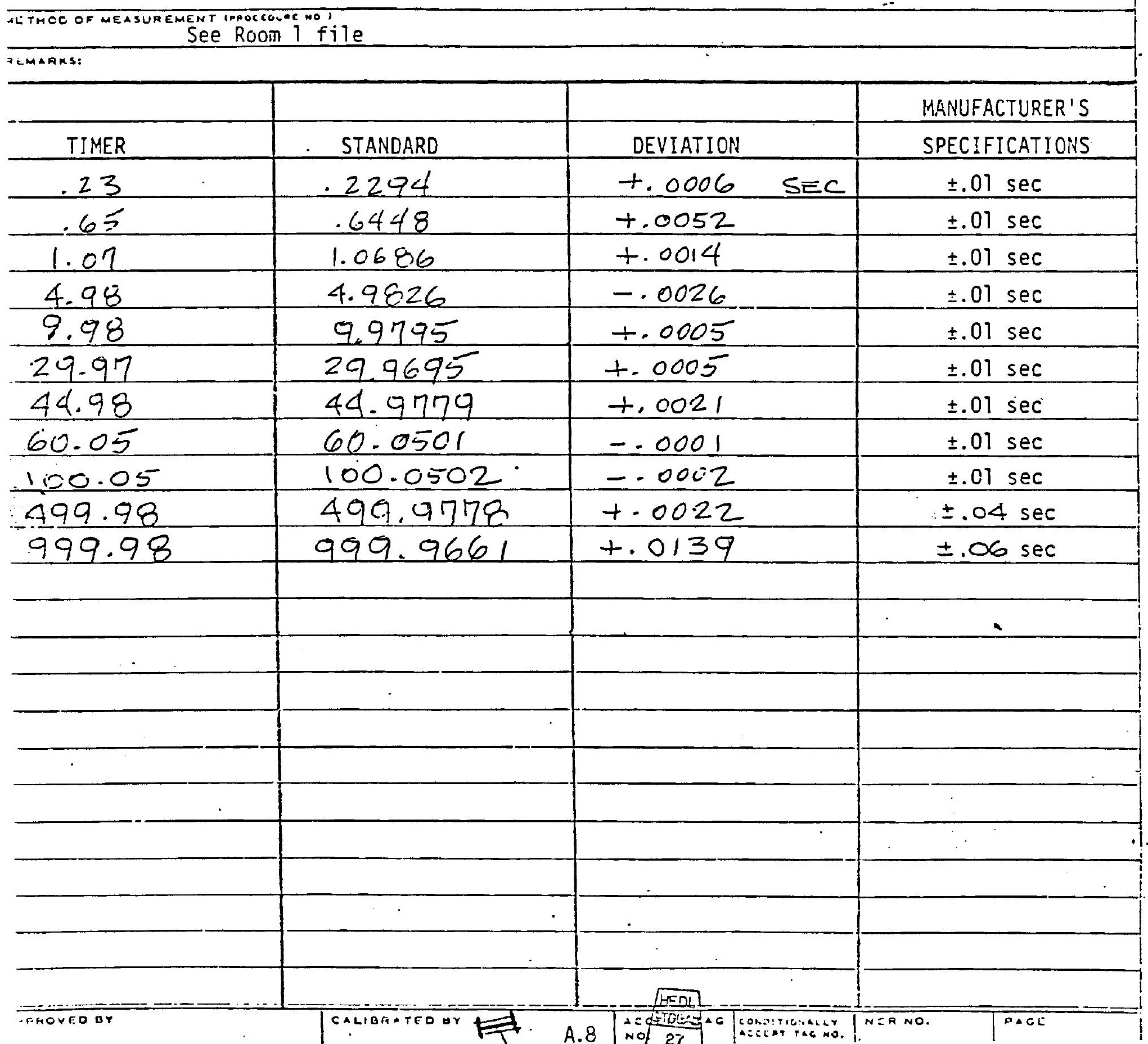


ADDENDUP 3

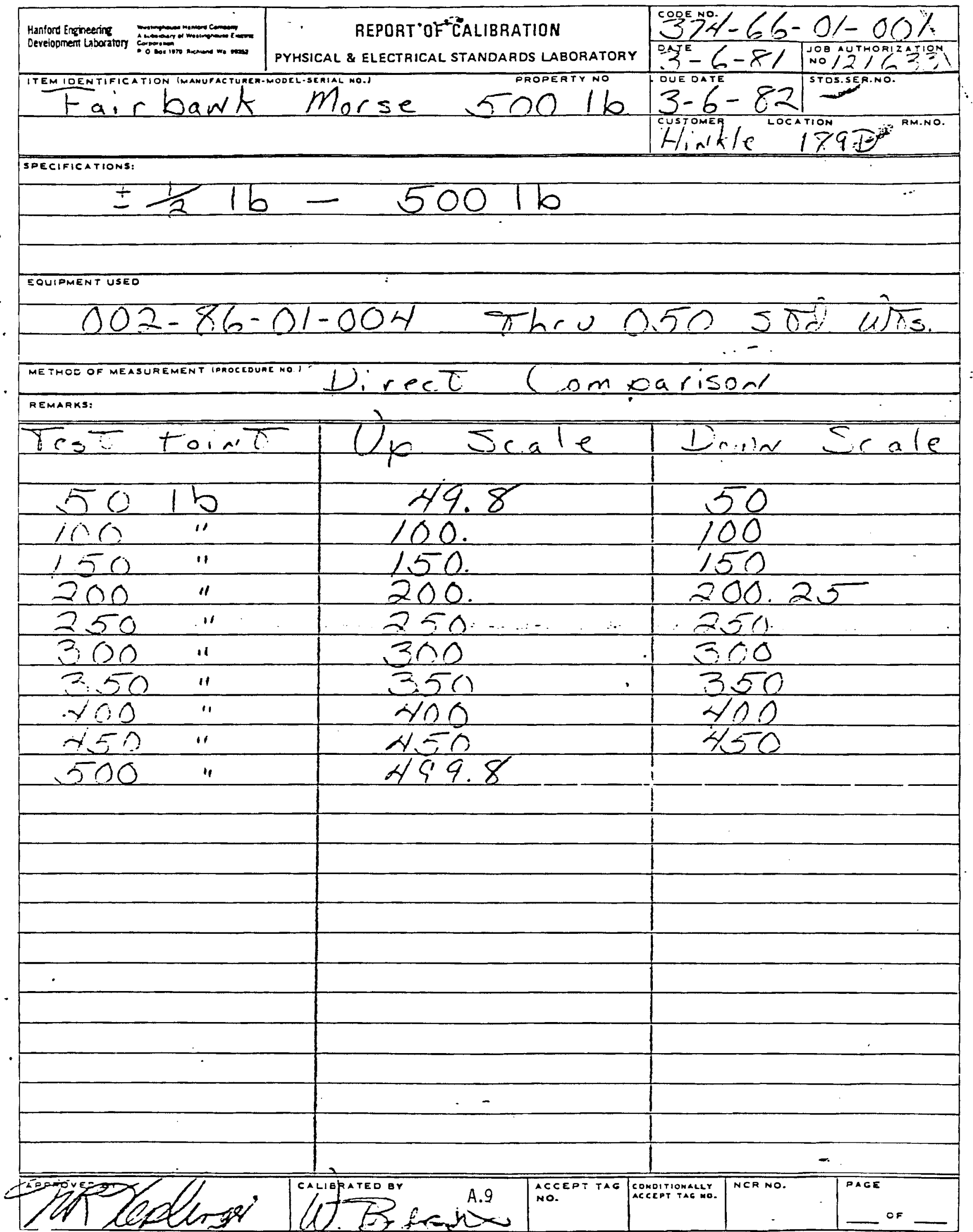




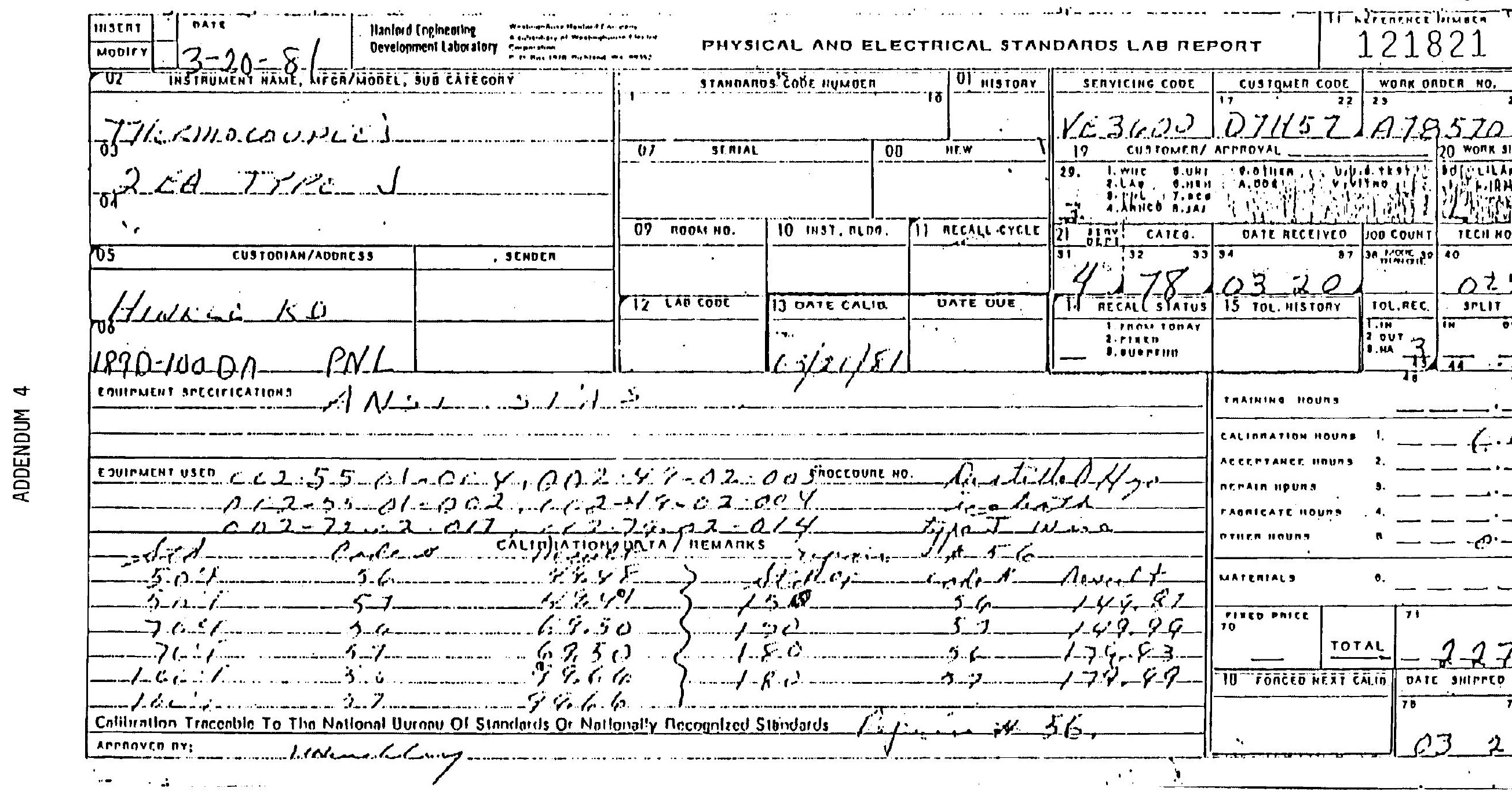




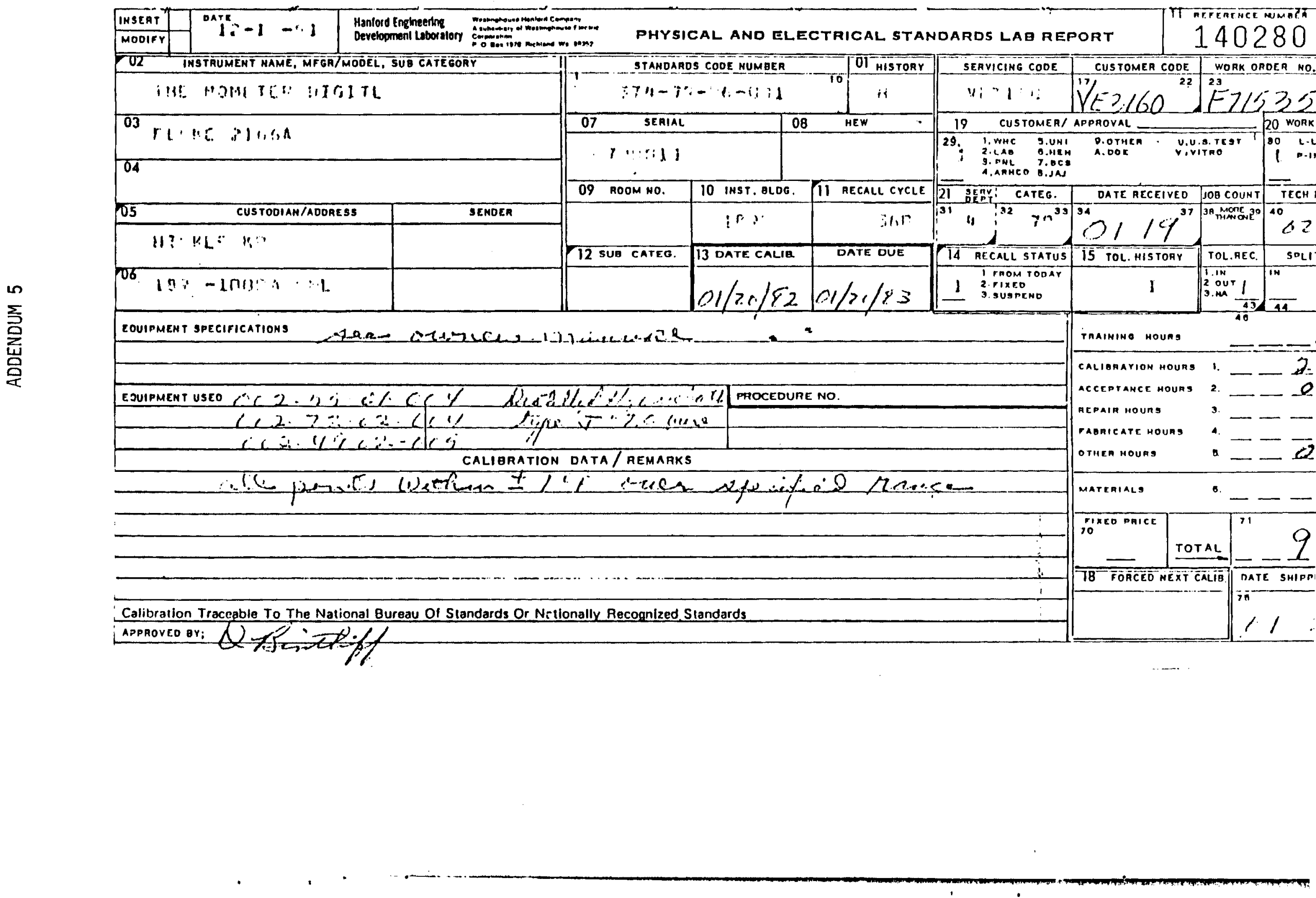


ADDENDUM 6

CALIBRATION DATA

A. Meter L544218

\begin{tabular}{|c|c|c|c|c|c|c|}
\hline $\begin{array}{c}\text { Run } \\
\text { no. }\end{array}$ & $\begin{array}{l}\text { We ight } \\
\text { (lb) }\end{array}$ & $\begin{array}{l}\text { Time } \\
\text { ( } \mathrm{sec}) \\
\end{array}$ & $\begin{array}{l}\text { Temp } \\
(\mathrm{OF})\end{array}$ & $\begin{array}{c}\rho \\
\left(1 b / \mathrm{ft}^{3}\right)\end{array}$ & $\begin{array}{c}Q \\
\text { (SCFM) }\end{array}$ & $\begin{array}{c}\text { Rotameter } \\
\text { Reading }\end{array}$ \\
\hline 1 & 100 & 269.02 & 55 & 62.39 & 11.08 & $11.3 \pm .1$ \\
\hline 2 & 100 & 271.03 & 55 & 62.39 & 11.00 & $11.0 \pm .25$ \\
\hline 3 & 100 & 305.28 & 54 & 62.39 & 9.79 & $10.0 \pm .25$ \\
\hline 4 & 100 & 344.92 & 52 & 62.40 & 8.67 & $9.0 \pm .25$ \\
\hline 5 & 100 & 387.19 & 50 & 62.41 & 7.72 & $8.0^{*}$ \\
\hline 6 & 100 & 446.14 & 49 & 62.41 & 6.68 & 7.0 \\
\hline 7 & 100 & 447.65 & 48 & 62.41 & 6.68 & 7.0 \\
\hline 8 & 100 & 527.78 & 48 & 62.41 & 5.64 & 6.0 \\
\hline 9 & 100 & 637.20 & 48 & 62.41 & 4.69 & 5.0 \\
\hline 10 & 100 & 804.12 & 48 & 62.41 & 3.69 & 4.0 \\
\hline 11 & 100 & 1095.68 & 48 & 62.41 & 2.74 & 3.0 \\
\hline 12 & 100 & 1650.39 & 49 & 62.41 & 1.83 & 2.0 \\
\hline 13 & 50 & 1502.39 & 51 & 62.41 & 1.00 & 1.2 \\
\hline 14 & 50 & 812.78 & 51 & 62.41 & 1.83 & 2.0 \\
\hline 15 & 50 & 540.85 & 51 & 62.41 & 2.74 & 3.0 \\
\hline 16 & 50 & 401.19 & 51 & 62.41 & 3.74 & 4.0 \\
\hline 17 & 50 & 317.71 & 51 & 62.41 & 4.69 & 5.0 \\
\hline 18 & 50 & 261.92 & 51 & 62.41 & 5.69 & 6.0 \\
\hline 19 & 50 & 223.21 & 51 & 62.41 & 6.68 & 7.0 \\
\hline 20 & 50 & 195.25 & 50 & 62.41 & 7.64 & $8.0 \pm .25$ \\
\hline 21 & 50 & 195.54 & 50 & 62.41 & 7.64 & $8.0 \pm .25$ \\
\hline 22 & 50 & 195.09 & 50 & 62.41 & 7.64 & $8.0 \pm .25$ \\
\hline 23 & 50 & 195.10 & 50 & 62.41 & 7.64 & $8.0 \pm .25$ \\
\hline 24 & 50 & 195.80 & 49 & 62.41 & 7.64 & $8.0 \pm .25$ \\
\hline 25 & 50 & 173.88 & 48 & 62.41 & 8.59 & $9.0 \pm .25$ \\
\hline 26 & 50 & 155.12 & 48 & 62.41 & 9.63 & $10.0 \pm .25$ \\
\hline 27 & 50 & 138.41 & 48 & 62.41 & 10.79 & $11.0 \pm .25$ \\
\hline 28 & 50 & 134.09 & 47 & 62.42 & 11.12 & $11.4^{\star}$ \\
\hline 29 & 100 & 268.73 & 47 & 62.42 & 11.12 & 11.4 \\
\hline
\end{tabular}

Steady reading. 
ADDENDUM 6

CALIBRATION DATA

B. Meter L544217

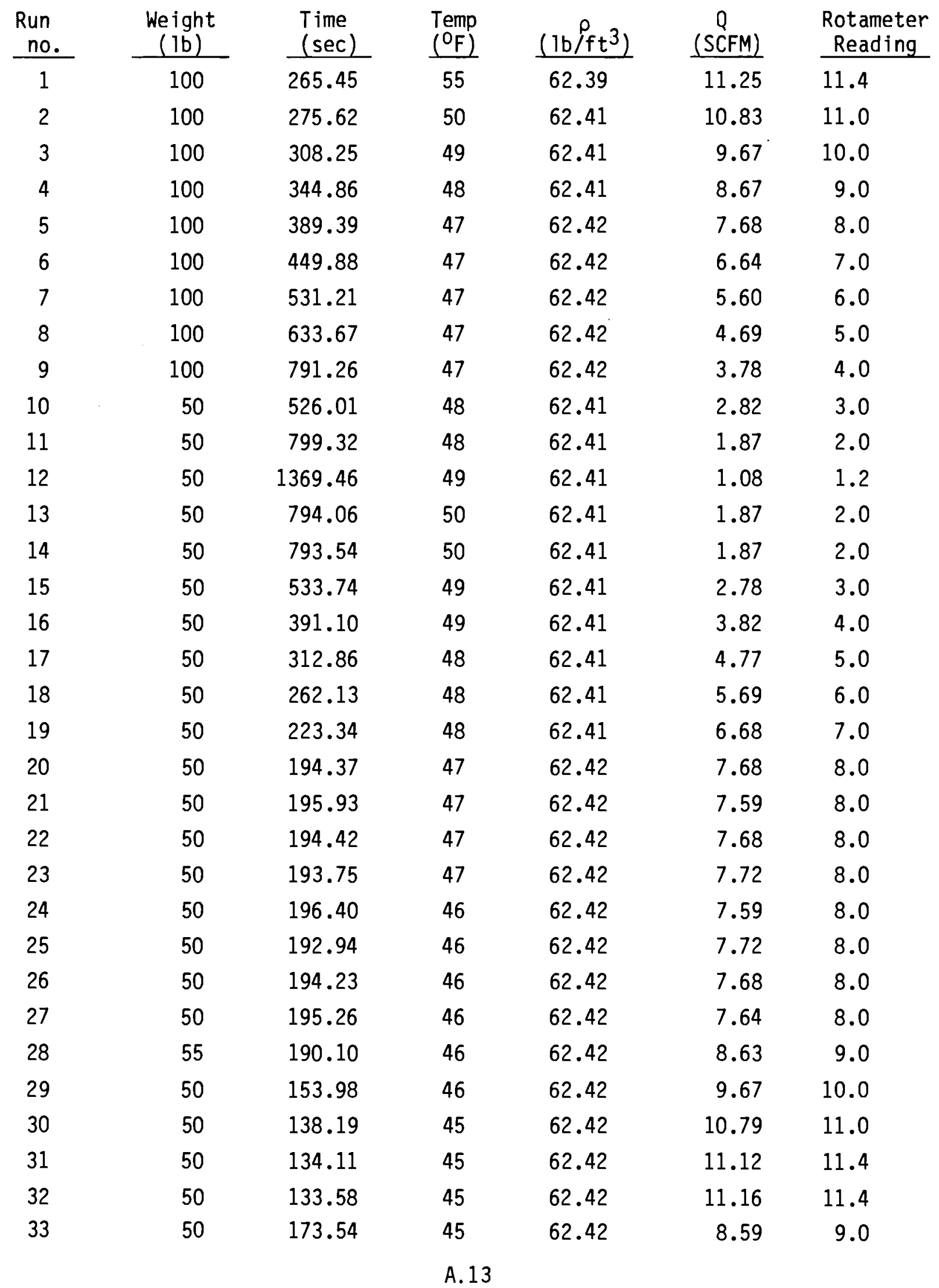




\section{UNCERTAINTY ANALYSIS}

Consider a dependent variable $y$ which is a continuous and differentiable function of $n$ independent variables $x_{n}$. The uncertainty interval of $y, w y$, is given by: ${ }^{(2)}$

$$
\omega y=\left\{\left(\frac{\partial y}{\partial x_{1}}\right)^{2} x_{1}^{2}+\left(\frac{\partial y}{\partial x_{2}}\right)^{2} w_{x_{2}}^{2}+\ldots+\left(\frac{\partial y}{\partial x_{n}}\right)^{2} \omega x_{n}^{2}\right\}^{1 / 2}
$$

Partial derivatives in Equation 7.1 are determined by stating the functional dependence of $y$ on the independent variables and then performing the indicated differentiation. Estimates of uncertainty intervals originate in a variety of sources. A typical example is to use one half of the minor gradation of an etched scale.

Mass flow rate is a function of the mass collected and the time of collection, hence

$$
\dot{\mathrm{m}}=\frac{\mathrm{m}}{\Delta \mathrm{t}}
$$

Differentiating Equation 7.2 and arranging the terms as in Equation 7.1 yields:

$$
\omega_{\dot{m}}=\left[\left(\frac{\partial \dot{m}}{\partial \overline{\Delta t}}\right)^{2} \omega_{\Delta t}^{2}+\left(\frac{\partial \dot{m}}{\partial m}\right)^{2} \omega_{m}^{2}\right] 1 / 2
$$

For this study the volume flow rate uncertainty equals the mass flow uncertainty since it can be shown that the uncertainty in water density is negligible for the temperature uncertainty encountered.

The mass flow rate uncertainty interval, $\omega_{\dot{m}}$, was calculated for the average of points A20 through A24 for rotameter L544218 and points B20 through B27 for rotameter L544217. The results are summarized in Table 3. 
TABLE 3. Summary of Uncertainty Interval Calculations for Average of Points B20 through B27 and Average of Points A20 through A24

Meter $\mathrm{L} 44218$

A20 through A24

\begin{tabular}{|c|c|c|c|}
\hline Parameter & Value & $\begin{array}{c}\text { Uncertainty } \\
\text { Interval }\end{array}$ & $\begin{array}{l}\text { Percent } \\
\text { Error, \% }\end{array}$ \\
\hline$\dot{\mathrm{m}}$ & $501 \mathrm{bm}$ & $\pm 0.51 \mathrm{bm}$ & 1.00 \\
\hline$t$ & $195.36 \mathrm{~s}$ & $\pm 0.25 \mathrm{~s}$ & 0.13 \\
\hline m & $0.256 \mathrm{lbm} / \mathrm{s}$ & $\begin{array}{l}+0.00258 \\
1 \mathrm{bm} / \mathrm{sec}\end{array}$ & 1.01 \\
\hline
\end{tabular}

Meter L44217

B20 through B27

$\begin{array}{llll}\mathrm{m} & 50 \mathrm{lbm} & \pm 0.5 \mathrm{lbm} & 1.00 \\ \mathrm{t} & 194.66 \mathrm{~s} & \pm 0.25 \mathrm{~s} & 0.13 \\ \dot{\mathrm{m}} & 0.257 \mathrm{lbm} / \mathrm{s} & \pm 0.00259 & 1.01 \\ & & & \end{array}$




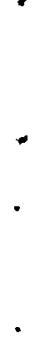


APPENDIX B

TEST STAND CALIBRATION DOCUMENTS 
• 


\section{TEST STAND CALIBRATION DOCUMENTS}

Test Stand Instrumentation List

\begin{tabular}{|c|c|c|c|c|}
\hline Item & $\begin{array}{c}\text { Identifying Code } \\
\text { (e.g., Serial Number) }\end{array}$ & $\begin{array}{c}\text { Calibration } \\
\text { Date } \\
\end{array}$ & $\begin{array}{c}\text { Expiration } \\
\text { Date } \\
\end{array}$ & $\begin{array}{l}\text { Calibration } \\
\text { Reference } \\
\text { Number } \\
\end{array}$ \\
\hline $\begin{array}{l}\text { Schutte \& } \\
\text { Koerting } \\
\text { mode } 161-06-692- \\
\text { M rotameters }(2)\end{array}$ & $\begin{array}{l}\text { L544217 U.S. Gov't. } \\
\text { L544218 U.S. Gov't. }\end{array}$ & $\begin{array}{l}1-28-82 \\
1-27-82\end{array}$ & $\begin{array}{l}1-28-83 \\
1-27-83\end{array}$ & $\begin{array}{l}\text { See App. A } \\
\text { See App. A }\end{array}$ \\
\hline $\begin{array}{l}\text { Thermocoup les, } \\
\text { (2) Type J }\end{array}$ & $\# 683, \# 668$ & $3-08-82$ & $3-08-83$ & HEDL 145575 \\
\hline $\begin{array}{l}\text { Validyne pres- } \\
\text { sure transducer, } \\
\text { P305D }\end{array}$ & & $3-22-82$ & $3-22-83$ & HEDL 145790 \\
\hline $\begin{array}{l}\text { Heise pressure } \\
\text { gage }\end{array}$ & & $10-01-81$ & $10-01-82$ & $\begin{array}{l}\text { HEDL } 124436 \\
\text { HEDL } \\
512-31-04-003\end{array}$ \\
\hline $\begin{array}{l}\text { Pioneer Photo- } \\
\text { tach } \\
0-100,000 \mathrm{rpm}\end{array}$ & PI 182408 & $2-16-82$ & $2-16-83$ & HEDL 131543 \\
\hline $\begin{array}{l}\text { Load cell, Inter- } \\
\text { face min ibeam } \\
\text { MB-5- } 4\end{array}$ & A16940 & $3-22-82$ & $3-22-83$ & HEDL 145791 \\
\hline $\begin{array}{l}\text { Keithley } 191 \\
\text { Digital multi- } \\
\text { meter }\end{array}$ & 22895 & $9-10-81$ & $9-30-82$ & $\begin{array}{l}\text { Manufacturer } \\
\text { calibration }\end{array}$ \\
\hline $\begin{array}{l}\text { Fluke Digital } \\
\text { Thermometer }\end{array}$ & 0790011 & $1-20-82$ & $1-20-83$ & $\begin{array}{l}\text { HEDL } \\
374-79-06-001\end{array}$ \\
\hline $\begin{array}{l}\text { DC Power Supplies } \\
\text { (2) }\end{array}$ & L544795 U.S. Gov't. & \multirow{2}{*}{\multicolumn{2}{|c|}{ not applicable }} & \\
\hline $\begin{array}{l}\text { Power Design, Inc } \\
4005\end{array}$ & L545663 U.S. Gov't. & & & \\
\hline
\end{tabular}




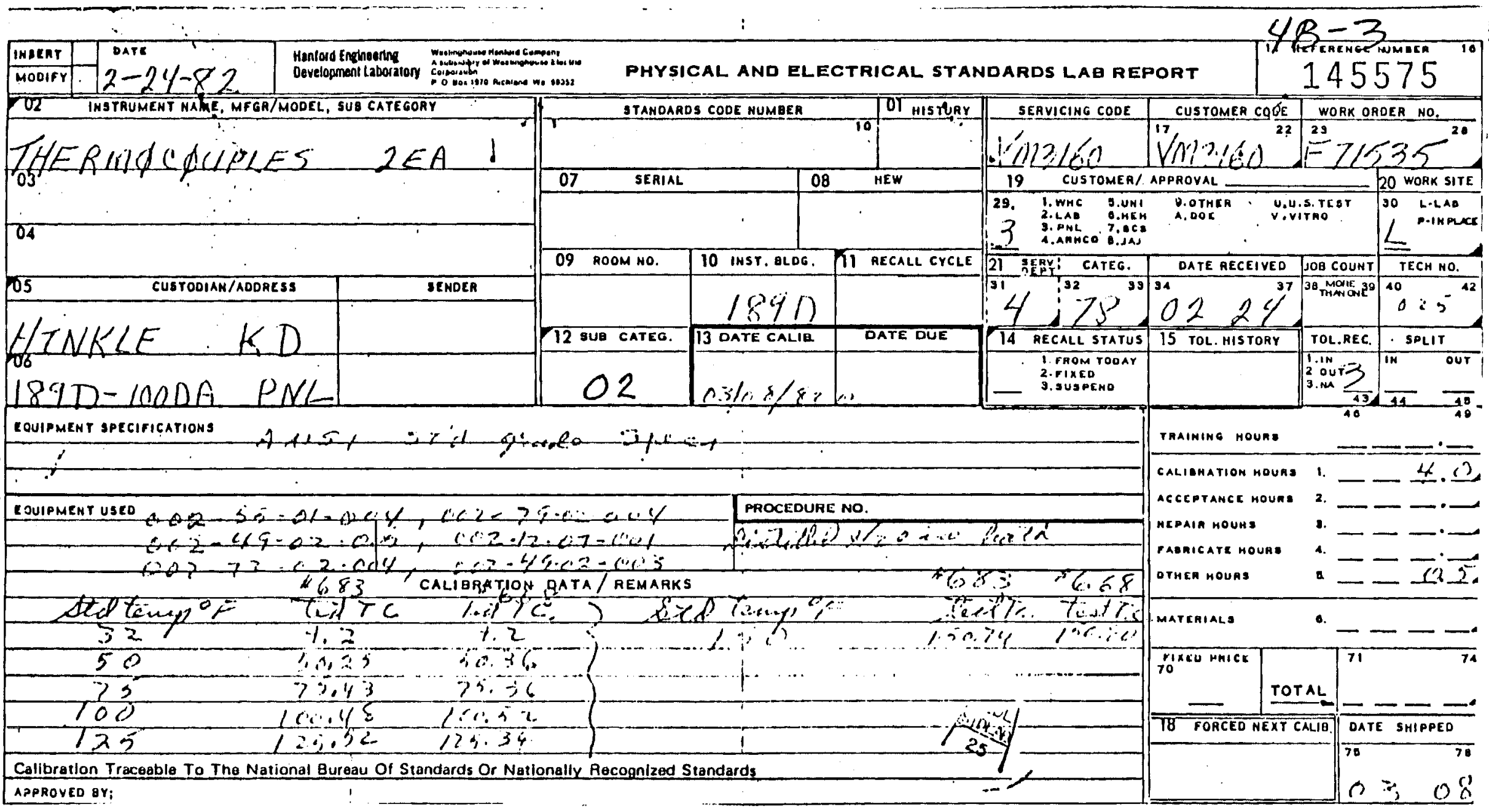




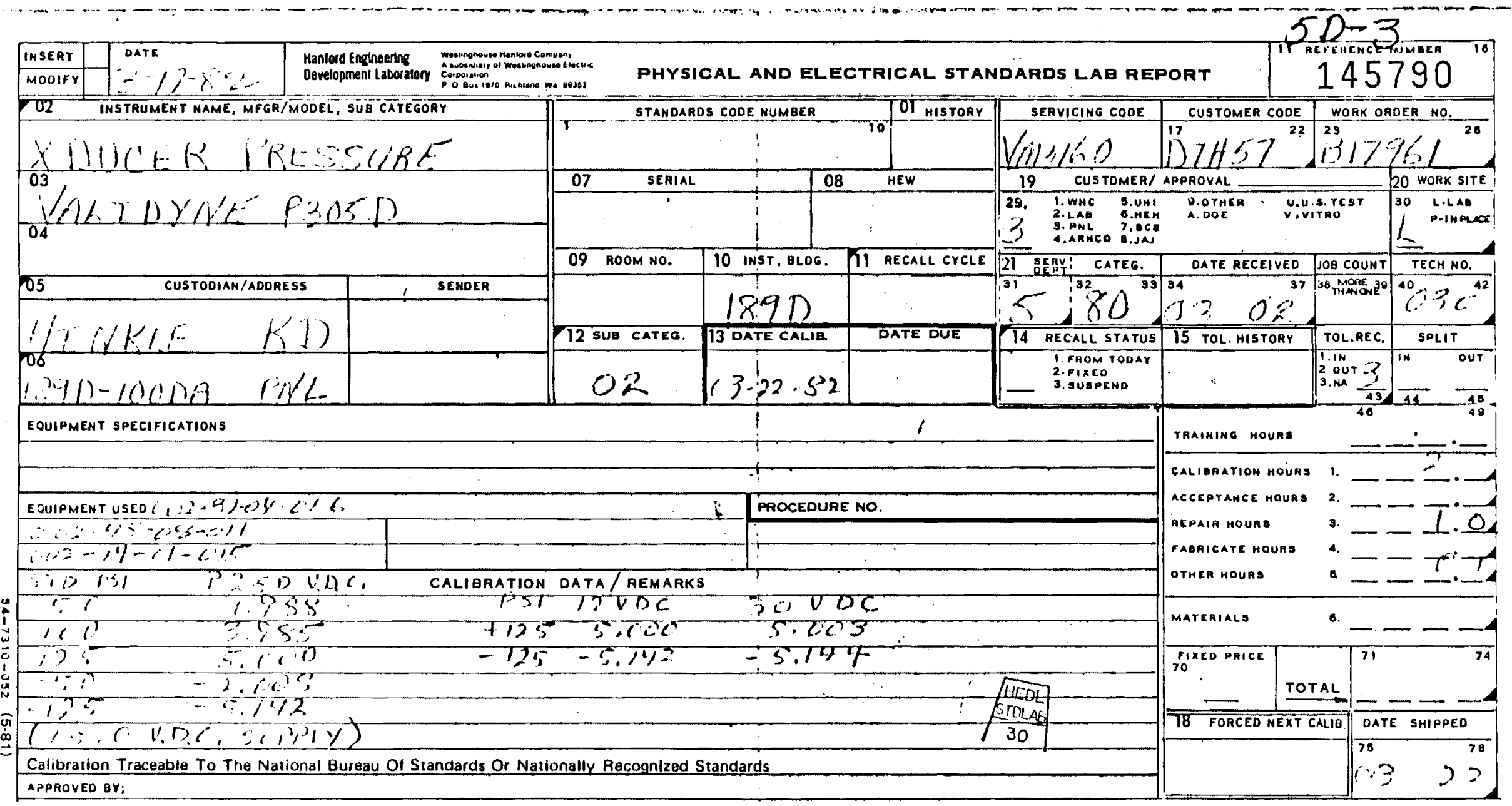




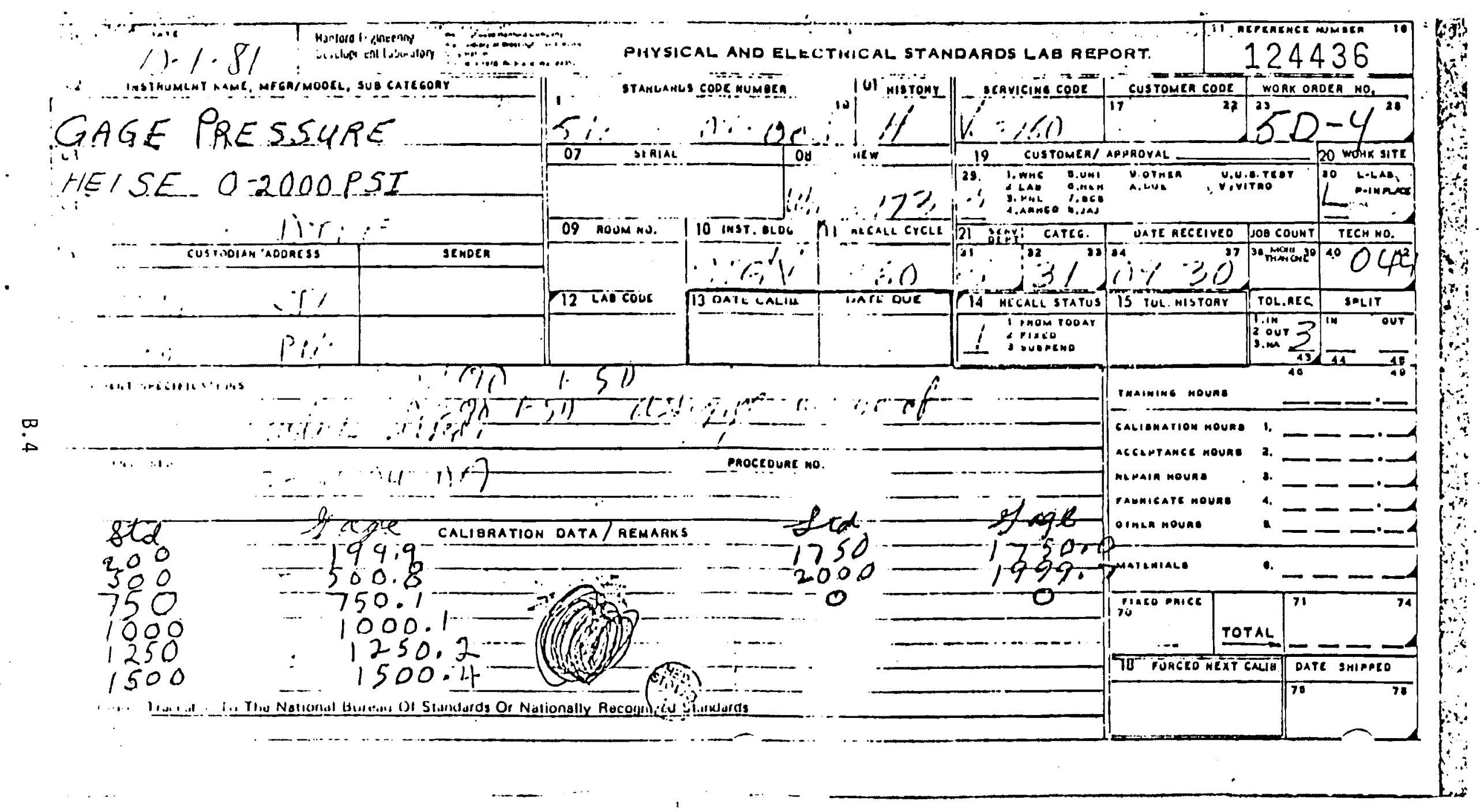




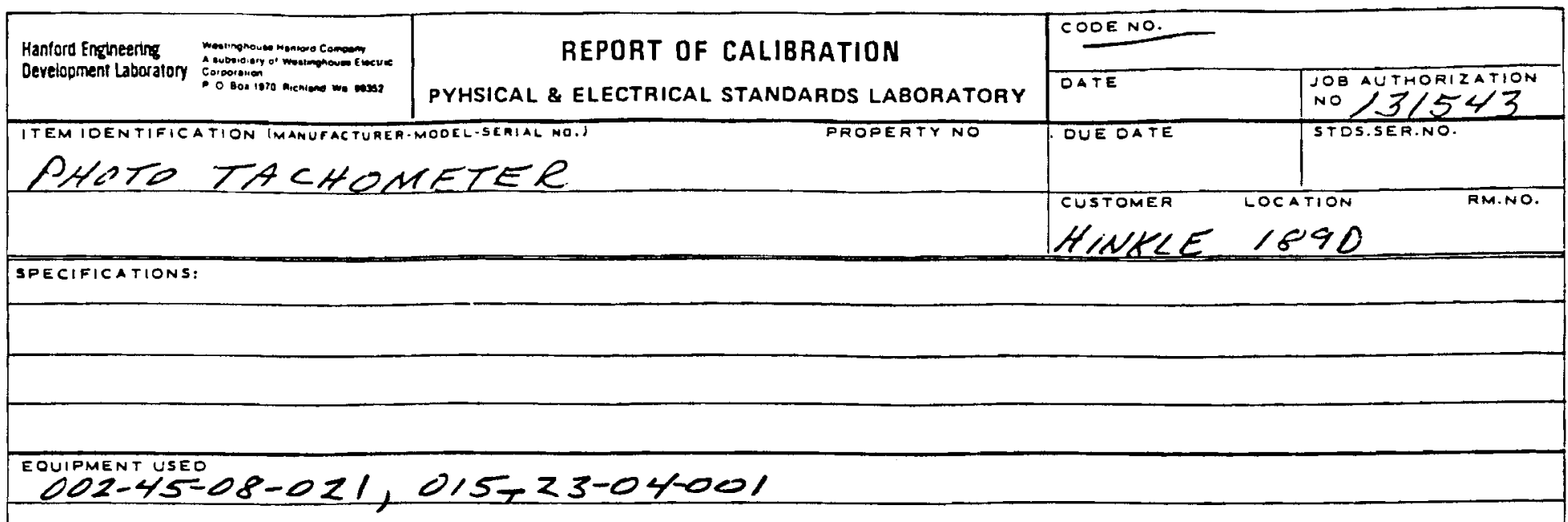

METHOD OF MEASUREMENT (PROCRDURE NO)

\section{REMARKS:}

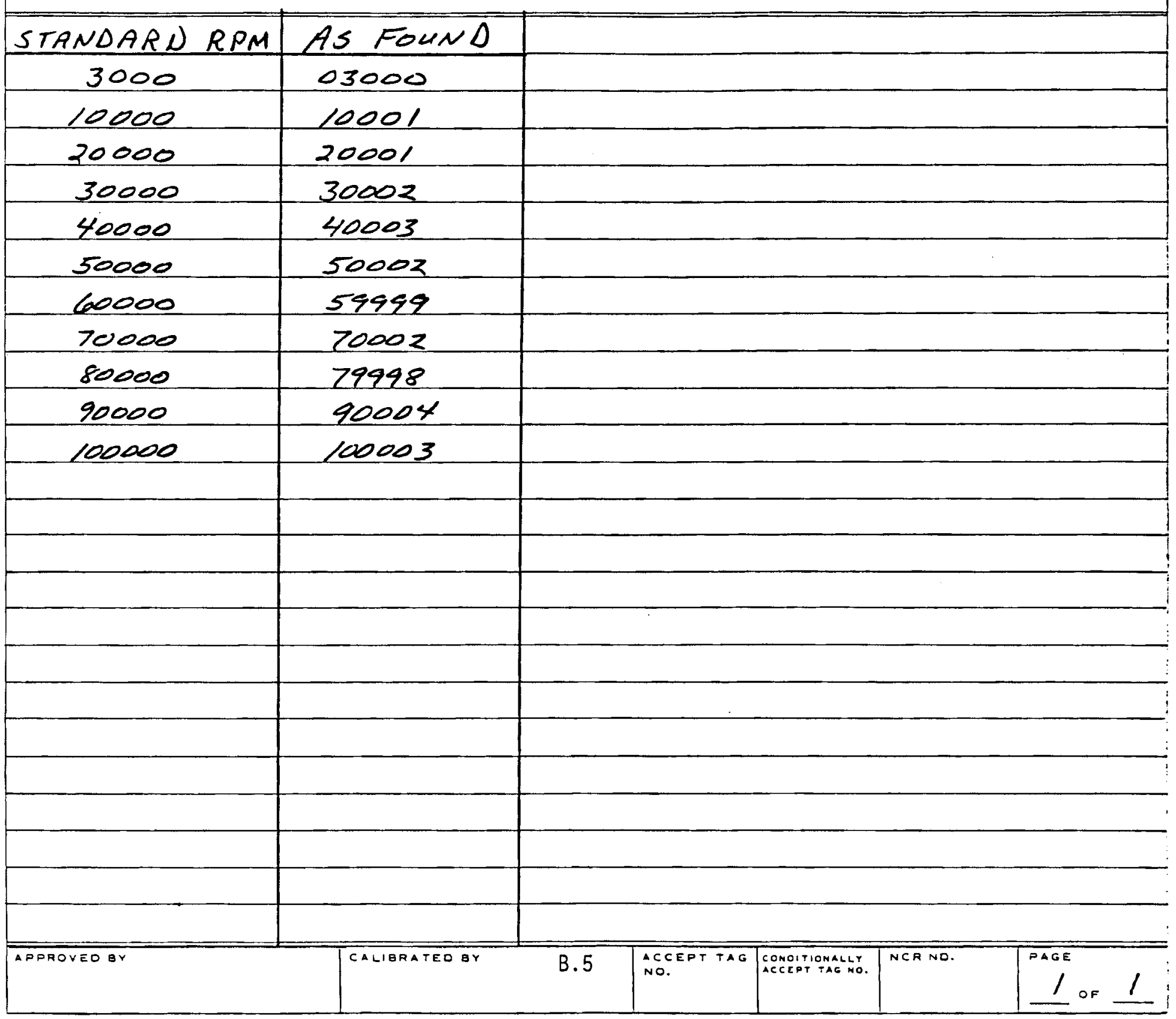




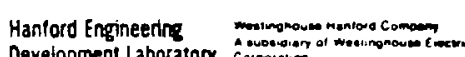

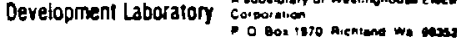

REPORT OF CALIBRATION

PYHSICAL \& ELECTRICAL STANDARDS LABORATORY

ITEM IOEN TIFICATION IMANUFACTURER-MODEL-SERIAL NO.

PROPERTYNO

TNTERFACE MINIBEAM

$\angle O A D C E L L M B-5-4$

SPECIFICATIONS: AS SHOWN BELOW

EOUPMENT USEO DILLON DOÄ-29-11-00/, 333B 0,5-14-01-00/, 2402A 002$45-08-021$

ME THOD OF MEASUREMENT (PROCEDUAE NO

MFE'S DATA

REMARKS:

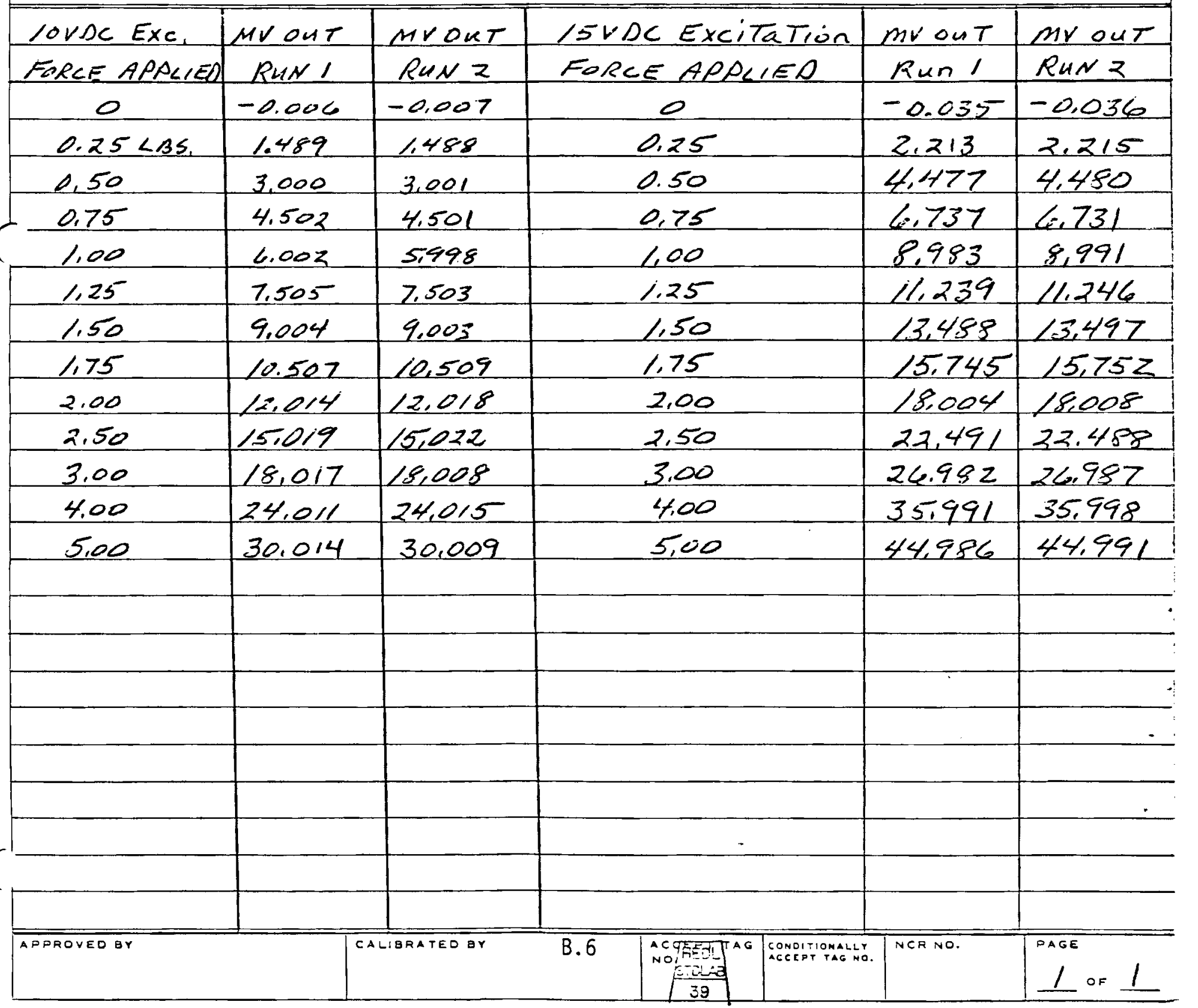


RECEIVED

SFP $16 \quad 1981$

J.L ACKERMAN

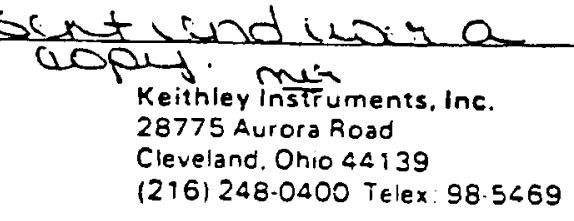

CERTIFICATE OF COMPLIANCE

AND CALIBRATION

MODEL 191

SERIAL NO. 22895

DATE September 10,1981

This notification serves to certify that the unit described above has been inspected and tested in accordance with specifications published by Keithley Instruments, Inc.

The accuracy and calibration of this instrument are traceable to the National Bureau of Standards through equipment which is calibrated at planned intervals by comparison to certified standards maintained in the Laboratories of Keithley Instruments, Inc.

The Calibration procedures of this company are in compliance with MIL-C-45652A.

R. Schroeder

Calibration Technician

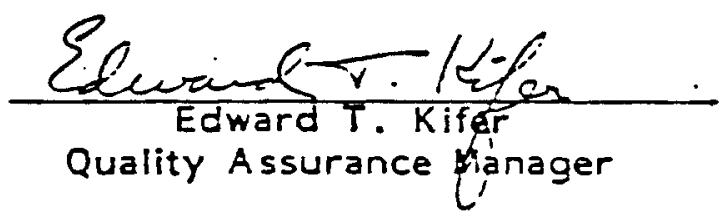

ETK :dr 


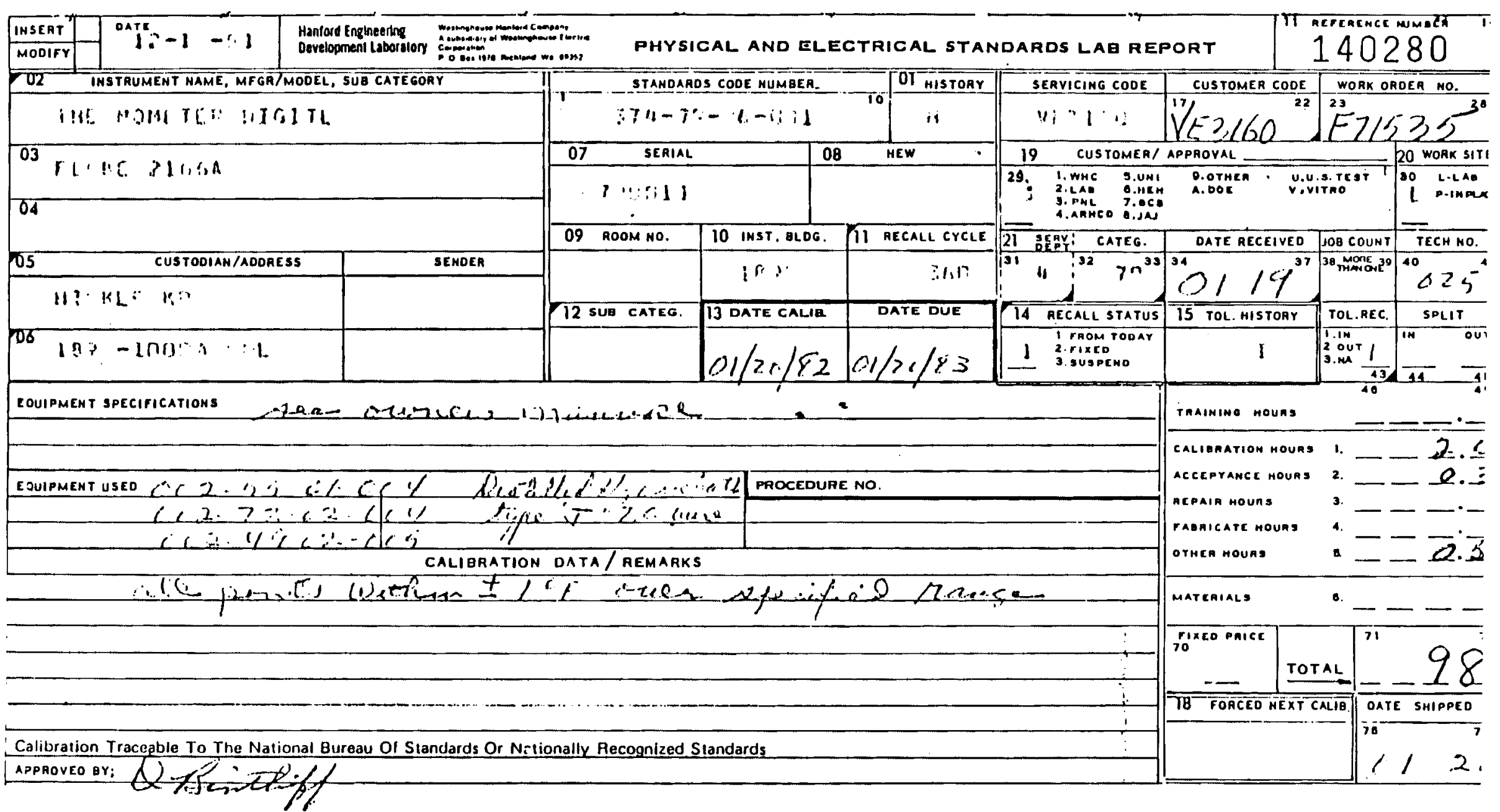


APPENDIX C

DATA SHEETS 

APPENDIX C

DATA SHEETS

DATA SHEET LEGEND

Roman numerals specify the class of data:

I Dynamic zeroes

II Performance data

III Preoperational test stand response tests.

Upper case letters denote the test stand configuration:

A Two open turbine bearings and shaft \#1,

B cleaned and reassembled as in configuration $A$,

C two sealed turbine bearings and shaft \#1,

D two sealed turbine bearings and shaft \#2,

E one open turbine bearing, one sealed turbine bearing and shaft \#2

Note: Performance data was not taken with configuration $D$.

Static zero - load cell response when turbine occupied its position

in the test stand, rotor stationary

Dynamic zero - air brake wheel and shroud removed, rotor spinning

Single asterisk, *, denotes a no load condition. The air brake wheel and shroud were in place but there was no air flow to the brake.

Double asterisk, ${ }^{\star}$, denotes a maximum speed test performed under the no load condition. 
I. DYNAMIC ZEROES

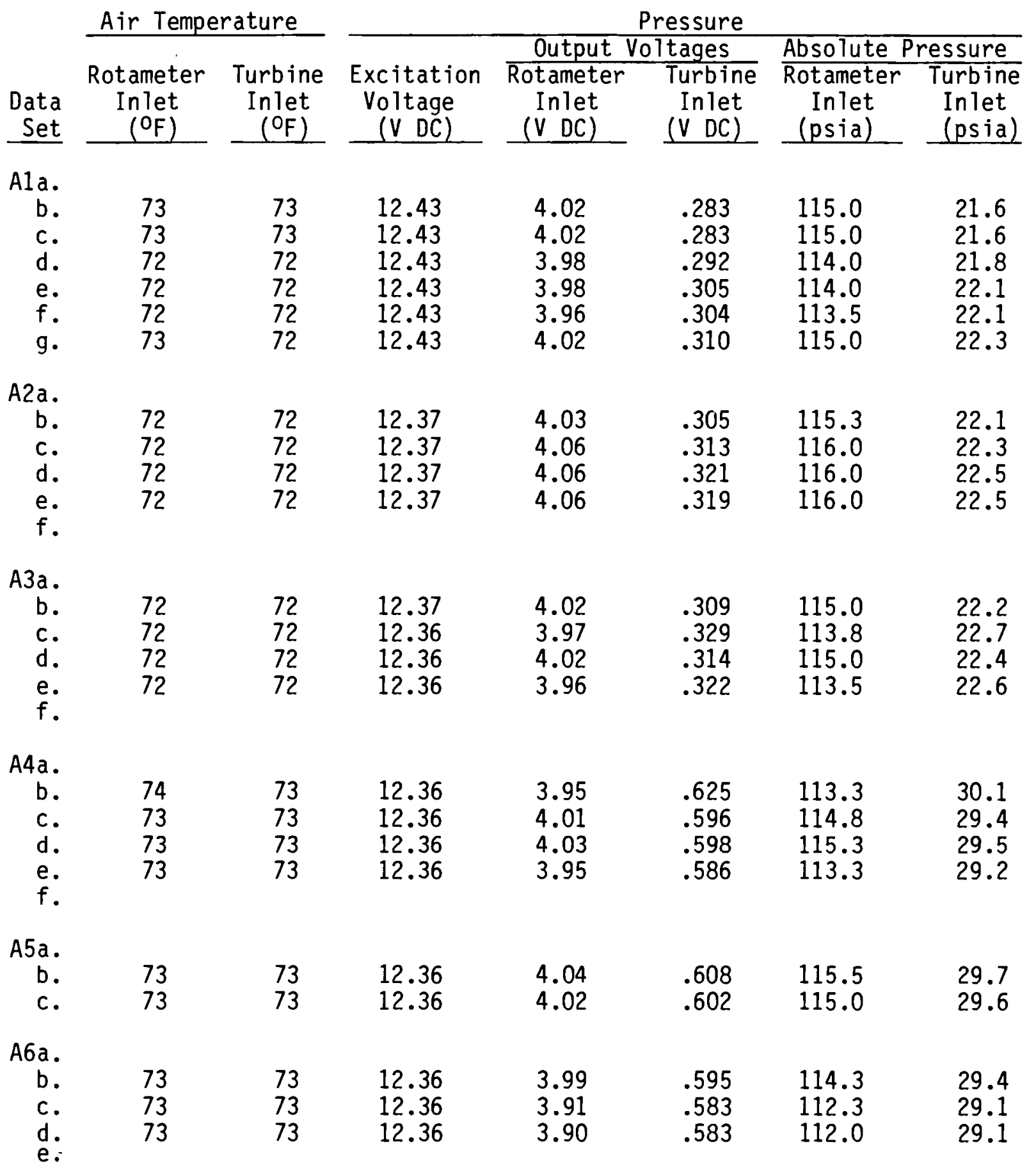


I. DYNAMIC ZEROES

\begin{tabular}{|c|c|c|c|c|c|c|c|}
\hline \multirow[b]{2}{*}{$\begin{array}{l}\text { Data } \\
\text { Set }\end{array}$} & \multicolumn{2}{|c|}{ Flow Rate } & \multicolumn{4}{|c|}{$\frac{\text { Load Cell Response }}{\text { Frcitation }}$} & \multirow[b]{2}{*}{$\begin{array}{l}\text { Speed } \\
(\mathrm{rpm})\end{array}$} \\
\hline & $\begin{array}{l}\text { Volume } \\
\text { (SCFM }\end{array}$ & $\begin{array}{c}\text { Mass } \\
(1 \mathrm{bm} / \mathrm{sec}) \\
\end{array}$ & $\begin{array}{l}\text { Zero } \\
\text { (V DC) } \\
\end{array}$ & $\begin{array}{l}\text { Voltage } \\
\text { ( } \mathrm{DOC}) \\
\end{array}$ & $\begin{array}{c}\text { Voltage } \\
(\mathrm{mV}) \\
\end{array}$ & $\begin{array}{l}\text { Force } \\
\text { (1bf) }\end{array}$ & \\
\hline $\begin{array}{c}\text { Ala. } \\
\text { b. } \\
\text { c. } \\
\text { d. } \\
\text { e. } \\
\text { f. } \\
\text { g. }\end{array}$ & $\begin{array}{l}1.0 \\
1.0 \\
1.0 \\
1.0 \\
1.0 \\
1.0\end{array}$ & $\begin{array}{l}.0028 \\
.0028 \\
.0028 \\
.0028 \\
.0028 \\
.0028\end{array}$ & .446 & $\begin{array}{l}8.45 \\
8.45 \\
8.45 \\
8.45 \\
8.46 \\
8.46 \\
8.46\end{array}$ & $\begin{array}{l}.475 \\
.464 \\
.467 \\
.464 \\
.465 \\
.470\end{array}$ & $\begin{array}{l}.0936 \\
.0914 \\
.0920 \\
.0914 \\
.0916 \\
.0926\end{array}$ & $\begin{array}{l}10000 \\
10000 \\
10000 \\
10000 \\
10000 \\
10000\end{array}$ \\
\hline $\begin{array}{c}\text { A2a. } \\
\text { b. } \\
\text { c. } \\
\text { d. } \\
\text { e. } \\
\text { f. }\end{array}$ & $\begin{array}{l}1.0 \\
1.0 \\
1.0 \\
1.0\end{array}$ & $\begin{array}{l}.0028 \\
.0028 \\
.0028 \\
.0028\end{array}$ & .483 & $\begin{array}{l}8.45 \\
8.45 \\
8.46 \\
8.46 \\
8.46 \\
8.46\end{array}$ & $\begin{array}{l}.481 \\
.472 \\
.482 \\
.470\end{array}$ & $\begin{array}{l}.0949 \\
.0930 \\
.0950 \\
.0926\end{array}$ & $\begin{array}{l}10000 \\
10000 \\
10000 \\
10000\end{array}$ \\
\hline $\begin{array}{r}\text { A3a. } \\
\text { b. } \\
\text { c. } \\
\text { d. } \\
\text { e. } \\
\text { f. }\end{array}$ & $\begin{array}{l}1.0 \\
1.0 \\
1.0 \\
1.0\end{array}$ & $\begin{array}{l}.0028 \\
.0028 \\
.0028 \\
.0028\end{array}$ & .496 & $\begin{array}{l}8.46 \\
8.46 \\
8.46 \\
8.46 \\
8.46 \\
8.46\end{array}$ & $\begin{array}{l}.472 \\
.478 \\
.482 \\
.480\end{array}$ & $\begin{array}{l}.0930 \\
.0942 \\
.0950 \\
.0946\end{array}$ & $\begin{array}{l}10000 \\
10000 \\
10000 \\
10000\end{array}$ \\
\hline $\begin{array}{c}\text { A4a. } \\
\text { b. } \\
\text { c. } \\
\text { d. } \\
\text { e. } \\
\text { f. }\end{array}$ & $\begin{array}{l}1.6 \\
1.5 \\
1.5 \\
1.5\end{array}$ & $\begin{array}{l}.0048 \\
.0045 \\
.0045 \\
.0045\end{array}$ & .483 & $\begin{array}{l}8.46 \\
8.46 \\
8.46 \\
8.46 \\
8.46 \\
8.46\end{array}$ & $\begin{array}{l}.452 \\
.455 \\
.460 \\
.450\end{array}$ & $\begin{array}{l}.0890 \\
.0896 \\
.0906 \\
.0887\end{array}$ & $\begin{array}{l}20000 \\
20000 \\
20000 \\
20000\end{array}$ \\
\hline $\begin{array}{r}\text { A5a. } \\
\text { b. } \\
\text { c. }\end{array}$ & $\begin{array}{l}1.5 \\
1.5\end{array}$ & $\begin{array}{l}.0045 \\
.0045\end{array}$ & .550 & $\begin{array}{l}8.46 \\
8.46 \\
8.46\end{array}$ & $\begin{array}{l}.455 \\
.453\end{array}$ & $\begin{array}{l}.0896 \\
.0892\end{array}$ & $\begin{array}{l}20000 \\
20000\end{array}$ \\
\hline $\begin{array}{c}\text { A6a. } \\
\text { b. } \\
\text { c. } \\
\text { d. } \\
\text { e. }\end{array}$ & $\begin{array}{l}1.5 \\
1.5 \\
1.5\end{array}$ & $\begin{array}{l}.0045 \\
.0045 \\
.0045\end{array}$ & .466 & $\begin{array}{l}8.46 \\
8.46 \\
8.46 \\
8.46 \\
8.46\end{array}$ & $\begin{array}{l}.464 \\
.459 \\
.462\end{array}$ & $\begin{array}{l}.0914 \\
.0904 \\
.0910\end{array}$ & $\begin{array}{l}20000 \\
20000 \\
20000\end{array}$ \\
\hline
\end{tabular}


I. DYNAMIC ZEROES

\begin{tabular}{|c|c|c|c|c|c|c|c|}
\hline \multirow[b]{2}{*}{$\begin{array}{r}\text { Data } \\
\text { Set } \\
\end{array}$} & \multicolumn{2}{|c|}{ Air Temperature } & \multicolumn{5}{|c|}{$\begin{array}{r}\text { Pressure } \\
\end{array}$} \\
\hline & $\begin{array}{c}\text { Rotameter } \\
\text { Inlet } \\
\text { (OF) }\end{array}$ & $\begin{array}{c}\text { Turbine } \\
\text { Inlet } \\
\text { (OF) } \\
\end{array}$ & $\begin{array}{c}\text { Excitation } \\
\text { Voltage } \\
(V D C) \\
\end{array}$ & $\begin{array}{c}\text { Output } 1 \\
\text { Rotameter } \\
\text { Inlet } \\
\text { (V DC) } \\
\end{array}$ & $\begin{array}{c}\text { oltages } \\
\text { Turbine } \\
\text { Inlet } \\
\text { (V DC) }\end{array}$ & $\begin{array}{l}\text { Absolute } \\
\text { Rotameter } \\
\text { Inlet } \\
\text { (psia) } \\
\end{array}$ & $\begin{array}{l}\text { ressure } \\
\text { Turbine } \\
\text { Inlet } \\
\text { (psia) } \\
\end{array}$ \\
\hline $\begin{array}{r}\text { A7a. } \\
\text { b. } \\
\text { c. } \\
\text { d. } \\
\text { e. } \\
\text { f. } \\
\text { g. }\end{array}$ & $\begin{array}{l}73 \\
73 \\
73 \\
73 \\
73\end{array}$ & $\begin{array}{l}73 \\
73 \\
73 \\
73 \\
73\end{array}$ & $\begin{array}{l}12.36 \\
12.36 \\
12.36 \\
12.36 \\
12.36\end{array}$ & $\begin{array}{l}3.95 \\
3.94 \\
3.92 \\
3.88 \\
3.84\end{array}$ & $\begin{array}{r}.977 \\
1.095 \\
1.106 \\
1.108 \\
1.099\end{array}$ & $\begin{array}{l}113.3 \\
113.0 \\
112.5 \\
111.5 \\
110.5\end{array}$ & $\begin{array}{l}38.9 \\
41.9 \\
42.2 \\
42.2 \\
42.0\end{array}$ \\
\hline $\begin{array}{l}\text { A8d. } \\
\text { b. } \\
\text { c. } \\
\text { d. } \\
\text { e. } \\
\text { f. }\end{array}$ & $\begin{array}{l}74 \\
74 \\
74 \\
74\end{array}$ & $\begin{array}{l}74 \\
74 \\
74 \\
74\end{array}$ & $\begin{array}{l}12.36 \\
12.36 \\
12.36 \\
12.36\end{array}$ & $\begin{array}{l}3.85 \\
3.78 \\
3.79 \\
3.74\end{array}$ & $\begin{array}{l}1.582 \\
1.650 \\
1.68 \\
1.66\end{array}$ & $\begin{array}{l}110.8 \\
109.0 \\
109.3 \\
108.0\end{array}$ & $\begin{array}{l}54.1 \\
55.8 \\
56.5 \\
56.0\end{array}$ \\
\hline $\begin{array}{r}\text { Bla. } \\
\text { b. } \\
\text { c. } \\
\text { d. } \\
\text { e. }\end{array}$ & $\begin{array}{l}75 \\
75 \\
75 \\
75\end{array}$ & $\begin{array}{l}75 \\
75 \\
75 \\
75\end{array}$ & $\begin{array}{l}12.45 \\
12.45 \\
12.45 \\
12.45\end{array}$ & $\begin{array}{l}4.03 \\
3.99 \\
4.07 \\
4.03\end{array}$ & $\begin{array}{l}.1801 \\
.1804 \\
.1857 \\
.1825\end{array}$ & $\begin{array}{l}115.1 \\
114.1 \\
116.1 \\
115.1\end{array}$ & $\begin{array}{l}18.9 \\
18.9 \\
19.0 \\
18.9\end{array}$ \\
\hline $\begin{array}{l}\text { B2a. } \\
\text { b. } \\
\text { c. } \\
\text { d. }\end{array}$ & $\begin{array}{l}75 \\
75 \\
75 \\
75\end{array}$ & $\begin{array}{l}75 \\
75 \\
75 \\
75\end{array}$ & $\begin{array}{l}12.45 \\
12.45 \\
12.45 \\
12.45\end{array}$ & $\begin{array}{l}4.04 \\
3.95 \\
3.96 \\
3.96\end{array}$ & $\begin{array}{l}.501 \\
.4913 \\
.4914 \\
.4892\end{array}$ & $\begin{array}{l}115.4 \\
113.1 \\
113.4 \\
113.4\end{array}$ & $\begin{array}{l}26.9 \\
26.7 \\
26.7 \\
26.6\end{array}$ \\
\hline $\begin{array}{l}\text { B3a. } \\
\text { b. } \\
\text { c. } \\
\text { d. }\end{array}$ & $\begin{array}{l}75 \\
75 \\
75 \\
75\end{array}$ & $\begin{array}{l}75 \\
75 \\
75 \\
75\end{array}$ & $\begin{array}{l}12.45 \\
12.45 \\
12.45 \\
12.45\end{array}$ & $\begin{array}{l}3.98 \\
3.98 \\
3.98 \\
3.89\end{array}$ & $\begin{array}{l}.9787 \\
.9809 \\
.9770 \\
.9737\end{array}$ & $\begin{array}{l}113.9 \\
113.9 \\
113.9 \\
111.6\end{array}$ & $\begin{array}{l}38.8 \\
38.9 \\
38.8 \\
38.7\end{array}$ \\
\hline B4a. & 75 & 75 & 12.45 & 3.90 & 1.633 & 111.9 & 55.2 \\
\hline $\begin{array}{r}\text { Cla. } \\
\text { b. } \\
\text { c. } \\
\text { d. } \\
\text { e. }\end{array}$ & $\begin{array}{l}73 \\
73 \\
73 \\
73\end{array}$ & $\begin{array}{l}73 \\
73 \\
73 \\
73\end{array}$ & $\begin{array}{l}12.58 \\
12.58 \\
12.58 \\
12.58\end{array}$ & $\begin{array}{l}4.07 \\
4.09 \\
4.08 \\
4.04\end{array}$ & $\begin{array}{l}.1182 \\
.1209 \\
.1178 \\
.1327\end{array}$ & $\begin{array}{l}116.1 \\
116.6 \\
116.3 \\
115.3\end{array}$ & $\begin{array}{l}17.3 \\
17.4 \\
17.3 \\
17.7\end{array}$ \\
\hline
\end{tabular}


I. DYNAMIC ZEROES

\begin{tabular}{|c|c|c|c|c|c|c|c|}
\hline \multirow[b]{2}{*}{$\begin{array}{r}\text { Data } \\
\text { Set }\end{array}$} & \multicolumn{2}{|c|}{ Flow Rate } & \multicolumn{4}{|c|}{ Load Cell } & \multirow[b]{2}{*}{$\begin{array}{l}\text { Speed } \\
\text { (rpm) }\end{array}$} \\
\hline & $\begin{array}{l}\text { Volume } \\
\text { (SCFM })\end{array}$ & $\begin{array}{c}\text { Mass } \\
(1 \mathrm{bm} / \mathrm{sec})\end{array}$ & $\begin{array}{c}\text { Static } \\
\text { Zero } \\
\left(\begin{array}{ll}V & 0 C\end{array}\right) \\
\end{array}$ & $\begin{array}{c}\text { Excitation } \\
\text { Voltage } \\
\text { (V DC) } \\
\end{array}$ & $\begin{array}{l}\text { Output } \\
\text { Voltage } \\
\text { (mV) }\end{array}$ & $\begin{array}{l}\text { Force } \\
\text { (lbf) }\end{array}$ & \\
\hline $\begin{array}{r}\text { A7a. } \\
\text { b. } \\
\text { c. } \\
\text { d. } \\
\text { e. } \\
\text { f. } \\
\text { g. }\end{array}$ & $\begin{array}{l}2.1 \\
2.3 \\
2.3 \\
2.3 \\
2.3\end{array}$ & $\begin{array}{l}.0065 \\
.0072 \\
.0072 \\
.0071 \\
.0071\end{array}$ & .550 & $\begin{array}{l}8.46 \\
8.46 \\
8.46 \\
8.46 \\
8.46 \\
8.46 \\
8.46\end{array}$ & $\begin{array}{l}.495 \\
.580 \\
.560 \\
.555 \\
.545\end{array}$ & $\begin{array}{l}.0975 \\
.1143 \\
.1103 \\
.1093 \\
.1074\end{array}$ & $\begin{array}{l}30000 \\
30000 \\
30000 \\
30000 \\
30000\end{array}$ \\
\hline $\begin{array}{r}\text { A8a. } \\
\text { b. } \\
\text { c. } \\
\text { d. } \\
\text { e. } \\
\text { f. }\end{array}$ & $\begin{array}{l}3.0 \\
3.1 \\
3.3 \\
3.3\end{array}$ & $\begin{array}{l}.0095 \\
.0097 \\
.0104 \\
.0103\end{array}$ & .507 & $\begin{array}{l}8.46 \\
8.46 \\
8.46 \\
8.46 \\
8.46 \\
8.46\end{array}$ & $\begin{array}{l}.566 \\
.540 \\
.520 \\
.505\end{array}$ & $\begin{array}{l}.112 \\
.106 \\
.102 \\
.100\end{array}$ & $\begin{array}{l}40000 \\
40000 \\
40000 \\
40000\end{array}$ \\
\hline $\begin{array}{r}\text { Bla. } \\
\text { b. } \\
\text { c. } \\
\text { d. } \\
\text { e. }\end{array}$ & $\begin{array}{l}<1 \\
<1 \\
<1 \\
<1\end{array}$ & $\begin{array}{l}<.0028 \\
<.0028 \\
<.0028 \\
<.0028\end{array}$ & .422 & $\begin{array}{l}8.47 \\
8.47 \\
8.47 \\
8.47 \\
8.47\end{array}$ & $\begin{array}{l}.436 \\
.429 \\
.433 \\
.430\end{array}$ & $\begin{array}{l}.0858 \\
.0844 \\
.0852 \\
.0846\end{array}$ & $\begin{array}{l}10000 \\
10000 \\
10000 \\
10000\end{array}$ \\
\hline $\begin{array}{r}\text { B2a. } \\
\text { b. } \\
c . \\
d .\end{array}$ & $\begin{array}{l}1.4 \\
1.4 \\
1.4 \\
1.4\end{array}$ & $\begin{array}{l}.0042 \\
.0041 \\
.0041 \\
.0041\end{array}$ & & $\begin{array}{l}8.47 \\
8.47 \\
8.47 \\
8.47\end{array}$ & $\begin{array}{l}.430 \\
.435 \\
.430 \\
.430\end{array}$ & $\begin{array}{l}.0846 \\
.0856 \\
.0846 \\
.0846\end{array}$ & $\begin{array}{l}20000 \\
20000 \\
20000 \\
20000\end{array}$ \\
\hline $\begin{array}{r}\text { B3a. } \\
\text { b. } \\
\text { c. } \\
\text { d. }\end{array}$ & $\begin{array}{l}2.1 \\
2.1 \\
2.1 \\
2.1\end{array}$ & $\begin{array}{l}.0065 \\
.0065 \\
.0065 \\
.0065\end{array}$ & & $\begin{array}{l}8.47 \\
8.47 \\
8.47 \\
8.47\end{array}$ & $\begin{array}{l}.440 \\
.450 \\
.450 \\
.460\end{array}$ & $\begin{array}{l}.0866 \\
.0885 \\
.0885 \\
.0905\end{array}$ & $\begin{array}{l}30000 \\
30000 \\
30000 \\
30000\end{array}$ \\
\hline B4a. & 3.1 & .0098 & & 8.47 & .460 & .0905 & 40000 \\
\hline $\begin{array}{c}\text { Cla. } \\
\text { b. } \\
\text { c. } \\
\text { d. } \\
\text { e. }\end{array}$ & $\begin{array}{l}<1 \\
<1 \\
<1 \\
<1\end{array}$ & $\begin{array}{l}<.0028 \\
<.028 \\
<.0028 \\
<.0028\end{array}$ & .447 & $\begin{array}{l}8.47 \\
8.47 \\
8.47 \\
8.47 \\
8.47\end{array}$ & $\begin{array}{l}.470 \\
.470 \\
.475 \\
.470\end{array}$ & $\begin{array}{l}.0925 \\
.0925 \\
.0935 \\
.0925\end{array}$ & $\begin{array}{l}10000 \\
10000 \\
10000 \\
10000\end{array}$ \\
\hline
\end{tabular}


I. DYNAMIC ZEROES

\begin{tabular}{|c|c|c|c|c|c|c|c|}
\hline \multirow[b]{2}{*}{$\begin{array}{r}\text { Data } \\
\text { Set } \\
\end{array}$} & \multicolumn{2}{|c|}{ Air Temperature } & \multicolumn{5}{|c|}{$\begin{array}{r}\text { Pressure } \\
\end{array}$} \\
\hline & $\begin{array}{c}\text { Rotameter } \\
\text { Inlet } \\
\text { (OF) } \\
\end{array}$ & $\begin{array}{c}\text { Turbine } \\
\text { Inlet } \\
\text { (OF) } \\
\end{array}$ & $\begin{array}{c}\text { Excitation } \\
\text { Voltage } \\
(V D C) \\
\end{array}$ & $\begin{array}{l}\text { Output V } \\
\text { Rotameter } \\
\text { Inlet } \\
\left(\begin{array}{l}\mathrm{V} \\
\mathrm{DC}\end{array}\right) \\
\end{array}$ & $\begin{array}{l}\text { Loltages } \\
\text { Turbine } \\
\text { Inlet } \\
\text { (V DC) } \\
\end{array}$ & $\begin{array}{c}\text { Absolute } \\
\text { Rotameter } \\
\text { Inlet } \\
\text { (psia) } \\
\end{array}$ & $\begin{array}{c}\text { Pressure } \\
\text { Turbine } \\
\text { Inlet } \\
\text { Ipsia } \\
\end{array}$ \\
\hline $\begin{array}{l}\mathrm{c} 2 \mathrm{a} . \\
\mathrm{b} . \\
\mathrm{c} . \\
\mathrm{d} .\end{array}$ & $\begin{array}{l}73 \\
72 \\
73 \\
72\end{array}$ & $\begin{array}{l}73 \\
72 \\
73 \\
72\end{array}$ & $\begin{array}{l}12.58 \\
12.58 \\
12.58 \\
12.58\end{array}$ & $\begin{array}{l}3.97 \\
3.97 \\
4.00 \\
4.06\end{array}$ & $\begin{array}{l}.4544 \\
.4555 \\
.4596 \\
.4688\end{array}$ & $\begin{array}{l}113.6 \\
113.6 \\
114.3 \\
115.8\end{array}$ & $\begin{array}{l}25.7 \\
25.7 \\
25.8 \\
26.1\end{array}$ \\
\hline $\begin{array}{l}\text { C3a. } \\
\text { b. } \\
\text { c. } \\
\text { d. }\end{array}$ & $\begin{array}{l}72 \\
72 \\
72 \\
72\end{array}$ & $\begin{array}{l}72 \\
72 \\
72 \\
72\end{array}$ & $\begin{array}{l}12.58 \\
12.58 \\
12.58 \\
12.58\end{array}$ & $\begin{array}{l}3.97 \\
3.92 \\
3.92 \\
3.99\end{array}$ & $\begin{array}{l}.8543 \\
.8450 \\
.8469 \\
.864\end{array}$ & $\begin{array}{l}113.6 \\
112.3 \\
112.3 \\
114.1\end{array}$ & $\begin{array}{l}35.7 \\
35.5 \\
35.5 \\
35.9\end{array}$ \\
\hline $\begin{array}{l}\mathrm{C} 4 \mathrm{a} . \\
\text { b. } \\
\mathrm{c} . \\
\text { d. }\end{array}$ & $\begin{array}{l}73 \\
73 \\
73 \\
73\end{array}$ & $\begin{array}{l}73 \\
73 \\
73 \\
73\end{array}$ & $\begin{array}{l}12.58 \\
12.58 \\
12.58 \\
12.58\end{array}$ & $\begin{array}{l}3.84 \\
3.83 \\
3.87 \\
3.85\end{array}$ & $\begin{array}{l}1.457 \\
1.457 \\
1.468 \\
1.462\end{array}$ & $\begin{array}{l}110.3 \\
110.1 \\
111.1 \\
110.6\end{array}$ & $\begin{array}{l}50.8 \\
50.8 \\
51.0 \\
50.9\end{array}$ \\
\hline $\begin{array}{l}\mathrm{C5a} . \\
\text { b. } \\
\text { c. } \\
\text { d. }\end{array}$ & $\begin{array}{l}73 \\
73 \\
73 \\
73\end{array}$ & $\begin{array}{l}73 \\
73 \\
73 \\
73\end{array}$ & $\begin{array}{l}12.58 \\
12.58 \\
12.58 \\
12.58\end{array}$ & $\begin{array}{l}3.71 \\
3.74 \\
3.75 \\
3.77\end{array}$ & $\begin{array}{l}2.322 \\
2.357 \\
2.357 \\
2.371\end{array}$ & $\begin{array}{l}107.1 \\
107.8 \\
108.1 \\
108.6\end{array}$ & $\begin{array}{l}72.4 \\
73.3 \\
73.3 \\
73.6\end{array}$ \\
\hline & & & & $\begin{array}{l}\text { Relative } \mathrm{Pr} \\
\text { Rotameter } \\
\text { Inlet } \\
\text { (psig) }\end{array}$ & $\begin{array}{l}\text { Turbine } \\
\text { Inlet } \\
\text { (psig) }\end{array}$ & $\begin{array}{c}\text { Absolute } \\
\text { Rotameter } \\
\text { Inlet } \\
\text { (psia) }\end{array}$ & $\begin{array}{c}\text { Pressure } \\
\text { Turbine } \\
\text { Inlet } \\
\text { (psia) }\end{array}$ \\
\hline $\begin{array}{r}\text { Dla. } \\
\text { b. }\end{array}$ & $\begin{array}{l}73 \\
73\end{array}$ & $\begin{array}{l}73 \\
73\end{array}$ & & $\begin{array}{r}100.4 \\
99.7\end{array}$ & $\begin{array}{l}-1.3 \\
-1.2\end{array}$ & $\begin{array}{l}118.5 \\
117.8\end{array}$ & $\begin{array}{l}16.8 \\
16.9\end{array}$ \\
\hline $\begin{array}{r}\mathrm{D} 2 \mathrm{a} . \\
\mathrm{b} .\end{array}$ & $\begin{array}{l}73 \\
73\end{array}$ & $\begin{array}{l}73 \\
73\end{array}$ & & $\begin{array}{l}97.4 \\
97.0\end{array}$ & $\begin{array}{l}5.4 \\
5.3\end{array}$ & $\begin{array}{l}115.5 \\
115.1\end{array}$ & $\begin{array}{l}23.5 \\
23.4\end{array}$ \\
\hline $\begin{array}{r}\text { D3a. } \\
\text { b. }\end{array}$ & $\begin{array}{l}72 \\
72\end{array}$ & $\begin{array}{l}72 \\
72\end{array}$ & & $\begin{array}{l}97.2 \\
96.5\end{array}$ & $\begin{array}{l}14.8 \\
14.7\end{array}$ & $\begin{array}{l}115.3 \\
114.6\end{array}$ & $\begin{array}{l}32.9 \\
32.8\end{array}$ \\
\hline $\begin{array}{r}\mathrm{D} 4 \mathrm{a} . \\
\mathrm{b} .\end{array}$ & $\begin{array}{l}72 \\
72\end{array}$ & $\begin{array}{l}72 \\
72\end{array}$ & & $\begin{array}{l}93.5 \\
95.1\end{array}$ & $\begin{array}{l}22.5 \\
22.8\end{array}$ & $\begin{array}{l}111.6 \\
113.2\end{array}$ & $\begin{array}{l}40.6 \\
40.9\end{array}$ \\
\hline
\end{tabular}


I. DYNAMIC ZEROES

\begin{tabular}{|c|c|c|c|c|c|c|c|}
\hline & $\mathrm{F} 10$ & Rate & & Load Cel & Respons & & \\
\hline Set & $\begin{array}{l}\text { Volume } \\
\left(\text { SCFM }_{0}\right)\end{array}$ & $\begin{array}{c}\text { Mass } \\
(1 \mathrm{bm} / \mathrm{sec})\end{array}$ & $\begin{array}{c}\text { Static } \\
\text { Zero } \\
(V D C) \\
\end{array}$ & $\begin{array}{c}\text { Excitation } \\
\text { Voltage } \\
\text { (V DC) } \\
\end{array}$ & $\begin{array}{l}\text { Output } \\
\text { Voltage } \\
(\mathrm{mV}) \\
\end{array}$ & $\begin{array}{l}\text { Force } \\
\text { (1bf) }\end{array}$ & $\begin{array}{c}\text { Speed } \\
(\mathrm{rpm}) \\
\end{array}$ \\
\hline $\begin{array}{l}\mathrm{C} 2 \mathrm{a} . \\
\mathrm{b} . \\
\mathrm{c} . \\
\text { d. }\end{array}$ & $\begin{array}{l}1.3 \\
1.3 \\
1.3 \\
1.3\end{array}$ & $\begin{array}{l}.0038 \\
.0038 \\
.0038 \\
.0038\end{array}$ & & $\begin{array}{l}8.47 \\
8.47 \\
8.47 \\
8.47\end{array}$ & $\begin{array}{l}.475 \\
.475 \\
.480 \\
.475\end{array}$ & $\begin{array}{l}.0935 \\
.0935 \\
.0945 \\
.0935\end{array}$ & $\begin{array}{l}20000 \\
20000 \\
20000 \\
20000\end{array}$ \\
\hline $\begin{array}{l}\text { c3a. } \\
\text { b. } \\
\text { c. } \\
\text { d. }\end{array}$ & $\begin{array}{l}1.9 \\
1.9 \\
1.9 \\
1.9\end{array}$ & $\begin{array}{l}.0058 \\
.0058 \\
.0058 \\
.0059\end{array}$ & & $\begin{array}{l}8.47 \\
8.47 \\
8.47 \\
8.47\end{array}$ & $\begin{array}{l}.470 \\
.473 \\
.470 \\
.485\end{array}$ & $\begin{array}{l}.0925 \\
.0931 \\
.0925 \\
.0954\end{array}$ & $\begin{array}{l}30000 \\
30000 \\
30000 \\
30000\end{array}$ \\
\hline $\begin{array}{l}\text { c4a. } \\
\text { b. } \\
\text { c. } \\
\text { d. }\end{array}$ & $\begin{array}{l}2.9 \\
2.9 \\
2.9 \\
2.9\end{array}$ & $\begin{array}{l}.0091 \\
.0091 \\
.0091 \\
.0091\end{array}$ & & $\begin{array}{l}8.47 \\
8.47 \\
8.47 \\
8.47\end{array}$ & $\begin{array}{l}.490 \\
.480 \\
.490 \\
.490\end{array}$ & $\begin{array}{l}.0964 \\
.0945 \\
.0964 \\
.0964\end{array}$ & $\begin{array}{l}40000 \\
40000 \\
40000 \\
40000\end{array}$ \\
\hline $\begin{array}{l}\mathrm{c} 5 \mathrm{a} . \\
\mathrm{b} . \\
\mathrm{c} . \\
\mathrm{d} .\end{array}$ & $\begin{array}{l}4.3 \\
4.3 \\
4.3 \\
4.3\end{array}$ & $\begin{array}{l}.0136 \\
.0136 \\
.0137 \\
.0137\end{array}$ & & $\begin{array}{l}8.47 \\
8.47 \\
8.47 \\
8.47\end{array}$ & $\begin{array}{l}.505 \\
.515 \\
.505 \\
.510\end{array}$ & $\begin{array}{l}.0994 \\
.1013 \\
.0994 \\
.1004\end{array}$ & $\begin{array}{l}50000 \\
50000 \\
50000 \\
50000\end{array}$ \\
\hline $\begin{array}{c}\text { D1a. } \\
\text { b. }\end{array}$ & $\begin{array}{l}<1 \\
<1\end{array}$ & $\begin{array}{l}<.0028 \\
<.0028\end{array}$ & & $\begin{array}{l}8.47 \\
8.47\end{array}$ & $\begin{array}{l}.505 \\
.505\end{array}$ & $\begin{array}{l}.0994 \\
.0994\end{array}$ & $\begin{array}{l}10000 \\
10000\end{array}$ \\
\hline $\begin{array}{r}\mathrm{D} 2 \mathrm{a} . \\
\mathrm{b} .\end{array}$ & $\begin{array}{l}1.5 \\
1.5\end{array}$ & $\begin{array}{l}.0045 \\
.0045\end{array}$ & & $\begin{array}{l}8.47 \\
8.47\end{array}$ & $\begin{array}{l}.540 \\
.550\end{array}$ & $\begin{array}{l}.1063 \\
.1082\end{array}$ & $\begin{array}{l}20000 \\
20000\end{array}$ \\
\hline $\begin{array}{c}\text { D3a. } \\
\text { b. }\end{array}$ & $\begin{array}{l}2.3 \\
2.3\end{array}$ & $\begin{array}{l}.0073 \\
.0072\end{array}$ & & $\begin{array}{l}8.47 \\
8.47\end{array}$ & $\begin{array}{l}.600 \\
.600\end{array}$ & $\begin{array}{l}.1181 \\
.1181\end{array}$ & $\begin{array}{l}30000 \\
30000\end{array}$ \\
\hline $\begin{array}{r}\mathrm{D} 4 \mathrm{a} . \\
\mathrm{b} .\end{array}$ & $\begin{array}{l}3.0 \\
3.0\end{array}$ & $\begin{array}{l}.0095 \\
.0096\end{array}$ & & $\begin{array}{l}8.47 \\
8.47\end{array}$ & $\begin{array}{l}.580 \\
.585\end{array}$ & $\begin{array}{l}.1141 \\
.1151\end{array}$ & $\begin{array}{l}40000 \\
40000\end{array}$ \\
\hline
\end{tabular}


I. DYNAMIC ZEROES

\begin{tabular}{|c|c|c|c|c|c|c|}
\hline \multirow[b]{2}{*}{$\begin{array}{r}\text { Data } \\
\text { Set } \\
\end{array}$} & \multicolumn{2}{|c|}{ Air Temperature } & \multicolumn{4}{|c|}{$\begin{array}{c}\text { Pressure } \\
\end{array}$} \\
\hline & $\begin{array}{c}\text { Rotameter } \\
\text { Inlet } \\
\left(\mathrm{O}^{\mathrm{F}}\right) \\
\end{array}$ & $\begin{array}{c}\text { Turbine } \\
\text { Inlet } \\
\text { (OF) } \\
\end{array}$ & $\begin{array}{l}\text { Relative } \\
\text { Rotameter } \\
\text { Inlet } \\
\text { (psig) } \\
\end{array}$ & $\begin{array}{c}\text { Pressure } \\
\text { Turbine } \\
\text { Inlet } \\
\text { (psig) } \\
\end{array}$ & $\begin{array}{l}\text { Absolute } \\
\text { Rotameter } \\
\text { Inlet } \\
\text { (psia) } \\
\end{array}$ & $\begin{array}{l}\text { Pressure } \\
\text { Turbine } \\
\text { Inlet } \\
\text { (psia) } \\
\end{array}$ \\
\hline $\begin{array}{r}\text { Ela. } \\
\text { b. }\end{array}$ & $\begin{array}{l}73 \\
73\end{array}$ & $\begin{array}{l}73 \\
73\end{array}$ & $\begin{array}{l}98.3 \\
96.6\end{array}$ & $\begin{array}{l}-1.2 \\
-1.3\end{array}$ & $\begin{array}{l}116.4 \\
114.7\end{array}$ & $\begin{array}{l}16.9 \\
16.8\end{array}$ \\
\hline $\begin{array}{r}\text { E2a. } \\
\text { b. } \\
\text { c. }\end{array}$ & $\begin{array}{l}73 \\
73 \\
73\end{array}$ & $\begin{array}{l}73 \\
73 \\
73\end{array}$ & $\begin{array}{l}94.8 \\
95.0 \\
96.5\end{array}$ & $\begin{array}{l}4.8 \\
5.3 \\
5.3\end{array}$ & $\begin{array}{l}112.9 \\
113.1 \\
114.6\end{array}$ & $\begin{array}{l}22.9 \\
23.4 \\
23.4\end{array}$ \\
\hline $\begin{array}{r}\text { E3a. } \\
\text { b. }\end{array}$ & $\begin{array}{l}73 \\
72\end{array}$ & $\begin{array}{l}73 \\
72\end{array}$ & $\begin{array}{l}93.5 \\
96.5\end{array}$ & $\begin{array}{l}13.8 \\
14.8\end{array}$ & $\begin{array}{l}111.6 \\
114.6\end{array}$ & $\begin{array}{l}31.9 \\
32.9\end{array}$ \\
\hline E4a & 72 & 72 & 95.1 & 22.0 & 113.2 & 40.1 \\
\hline
\end{tabular}

C. 8 
I. DYNAMIC ZEROES

\begin{tabular}{|c|c|c|c|c|c|c|c|}
\hline & Flow & Rate & & Load Cell R & sponse & & \\
\hline Set & $\begin{array}{r}\text { Volume } \\
\text { (SCFM })\end{array}$ & $\begin{array}{c}\text { Mass } \\
(1 \mathrm{bm} / \mathrm{sec})\end{array}$ & $\begin{array}{l}\text { Static } \\
\text { Zero } \\
\text { (V DC) } \\
\end{array}$ & $\begin{array}{c}\text { Excitation } \\
\text { Voltage } \\
\text { (V DC) } \\
\end{array}$ & $\begin{array}{c}\text { Output } \\
\text { Voltage } \\
\text { (mV) } \\
\end{array}$ & $\begin{array}{l}\text { Force } \\
\text { (1bf) }\end{array}$ & $\begin{array}{c}\text { Speed } \\
\text { (rpm) } \\
\end{array}$ \\
\hline $\begin{array}{r}\text { Ela. } \\
\text { b. }\end{array}$ & $\begin{array}{l}1 \\
1\end{array}$ & $\begin{array}{l}.0028 \\
.0028\end{array}$ & & $\begin{array}{l}8.47 \\
8.47\end{array}$ & $\begin{array}{l}.580 \\
.590\end{array}$ & $\begin{array}{l}.1141 \\
.1161\end{array}$ & $\begin{array}{l}10000 \\
10000\end{array}$ \\
\hline $\begin{array}{r}2 a . \\
\text { b. } \\
\text { c. }\end{array}$ & $\begin{array}{l}1.4 \\
1.5 \\
1.5\end{array}$ & $\begin{array}{l}.0041 \\
.0045 \\
.0045\end{array}$ & & $\begin{array}{l}8.47 \\
8.47 \\
8.47\end{array}$ & $\begin{array}{l}.600 \\
.605 \\
.600\end{array}$ & $\begin{array}{l}.1181 \\
.1190 \\
.1181\end{array}$ & $\begin{array}{l}20000 \\
20000 \\
20000\end{array}$ \\
\hline $\begin{array}{r}3 a . \\
\text { b. }\end{array}$ & $\begin{array}{l}2.3 \\
2.3\end{array}$ & $\begin{array}{l}.0071 \\
.0072\end{array}$ & & $\begin{array}{l}8.47 \\
8.47\end{array}$ & $\begin{array}{l}.640 \\
.660\end{array}$ & $\begin{array}{l}.1259 \\
.1299\end{array}$ & $\begin{array}{l}30000 \\
30000\end{array}$ \\
\hline 4a. & 3.0 & .0096 & & 8.47 & .630 & .1240 & 40000 \\
\hline
\end{tabular}


I. DYNAMIC ZEROES

\section{Summary}

\begin{tabular}{|c|c|c|}
\hline $\begin{array}{r}\text { Data } \\
\text { Set } \\
\end{array}$ & $\begin{array}{l}\text { Speed } \\
\text { (rpm) }\end{array}$ & $\begin{array}{c}\text { Dynamic } \\
\text { Zero } \\
\text { (1bf) avg } \\
\end{array}$ \\
\hline $\begin{array}{l}A 1,2,3 \\
A 4,5,6 \\
A 7 \\
A 8\end{array}$ & $\begin{array}{l}10000 \\
20000 \\
30000 \\
40000\end{array}$ & $\begin{array}{l}.093 \\
.090 \\
.108 \\
.105\end{array}$ \\
\hline $\begin{array}{l}\text { B1 } \\
\text { B2 } \\
\text { B3 } \\
\text { B4 }\end{array}$ & $\begin{array}{l}10000 \\
20000 \\
30000 \\
40000\end{array}$ & $\begin{array}{l}.085 \\
.085 \\
.089 \\
.091\end{array}$ \\
\hline $\begin{array}{l}\text { C1 } \\
\text { C2 } \\
\text { C3 } \\
\text { C4 } \\
\text { C5 }\end{array}$ & $\begin{array}{l}10000 \\
20000 \\
30000 \\
40000 \\
50000\end{array}$ & $\begin{array}{l}.092 \\
.094 \\
.093 \\
.096 \\
.100\end{array}$ \\
\hline $\begin{array}{l}\text { D1 } \\
\text { D2 } \\
\text { D3 } \\
\text { D4 }\end{array}$ & $\begin{array}{l}10000 \\
20000 \\
30000 \\
40000\end{array}$ & $\begin{array}{l}.099 \\
.107 \\
.118 \\
.115\end{array}$ \\
\hline $\begin{array}{l}\text { E1 } \\
\text { E2 } \\
\text { E3 }\end{array}$ & $\begin{array}{l}10000 \\
20000 \\
30000 \\
40000\end{array}$ & $\begin{array}{l}.115 \\
.118 \\
.128 \\
.124\end{array}$ \\
\hline
\end{tabular}


II. PERFORMANCE DATA

Air Temperature

\begin{tabular}{|c|c|c|c|c|c|c|c|}
\hline \multirow[b]{2}{*}{$\begin{array}{r}\text { Data } \\
\text { Set } \\
\end{array}$} & \multicolumn{2}{|c|}{ Alr Temperdacure } & \multicolumn{5}{|c|}{ Pressure } \\
\hline & $\begin{array}{c}\text { Rotameter } \\
\text { Inlet } \\
\text { (O F) } \\
\end{array}$ & $\begin{array}{c}\text { Turbine } \\
\text { Inlet } \\
\left(O^{\circ}\right) \\
\end{array}$ & $\begin{array}{l}\text { Transducer } \\
\text { Excitation } \\
\text { Voltage } \\
(V \text { DC }) \\
\end{array}$ & $\begin{array}{c}\text { Rotameter } \\
\text { Inlet } \\
\text { (V) } \\
\end{array}$ & $\begin{array}{c}\text { Turbine } \\
\text { Inlet } \\
\text { (V) }\end{array}$ & $\begin{array}{c}\text { Rotameter } \\
\text { Inlet } \\
\text { (psia) } \\
\end{array}$ & $\begin{array}{l}\text { Turbine } \\
\text { Inlet } \\
\text { (psia) }\end{array}$ \\
\hline $\begin{array}{l}\text { la. } \\
\text { b* } \\
\text { c. } \\
\text { d. } \\
\text { e. } \\
\text { f. } \\
\text { g. } \\
\text { h. } \\
\text { i. }\end{array}$ & $\begin{array}{l}73 \\
74 \\
74 \\
73 \\
73 \\
73 \\
73 \\
73\end{array}$ & $\begin{array}{l}72 \\
72 \\
73 \\
73 \\
73 \\
73 \\
73 \\
73\end{array}$ & $\begin{array}{l}12.19 \\
12.19 \\
12.19 \\
12.19 \\
12.19 \\
12.19 \\
12.19 \\
12.19\end{array}$ & $\begin{array}{l}3.96 \\
3.76 \\
3.58 \\
3.65 \\
3.63 \\
3.65 \\
3.55 \\
3.49\end{array}$ & $\begin{array}{l}.620 \\
.822 \\
1.21 \\
1.57 \\
2.02 \\
2.31 \\
2.76 \\
3.31\end{array}$ & $\begin{array}{l}113.3 \\
108.3 \\
103.8 \\
104.8 \\
105.0 \\
105.5 \\
103.0 \\
101.5\end{array}$ & $\begin{array}{l}29.8 \\
34.8 \\
44.5 \\
53.5 \\
64.8 \\
72.0 \\
83.3 \\
97.0\end{array}$ \\
\hline $\begin{array}{c}\text { A2a. } \\
\text { b. } \\
\text { c. } \\
\text { d. } \\
\text { e. } \\
\text { f. } \\
\text { g. }\end{array}$ & $\begin{array}{l}74 \\
74 \\
74 \\
73 \\
73 \\
73\end{array}$ & $\begin{array}{l}73 \\
73 \\
73 \\
73 \\
73 \\
73\end{array}$ & $\begin{array}{l}12.19 \\
12.19 \\
12.19 \\
12.19 \\
12.19 \\
12.19\end{array}$ & $\begin{array}{l}3.83 \\
3.60 \\
3.57 \\
3.54 \\
3.48 \\
3.50\end{array}$ & $\begin{array}{l}1.28 \\
1.59 \\
2.01 \\
2.40 \\
2.76 \\
3.17\end{array}$ & $\begin{array}{l}110.0 \\
104.3 \\
103.5 \\
102.8 \\
101.3 \\
101.8\end{array}$ & $\begin{array}{l}46.3 \\
54.0 \\
64.5 \\
74.3 \\
83.3 \\
93.5\end{array}$ \\
\hline $\begin{array}{c}\text { A3a. } \\
\text { b.* } \\
\text { c. } \\
\text { d. } \\
\text { e. } \\
\text { f. } \\
\text { g. }\end{array}$ & $\begin{array}{l}73 \\
73 \\
73 \\
73 \\
73 \\
74\end{array}$ & $\begin{array}{l}73 \\
73 \\
73 \\
73 \\
73 \\
74\end{array}$ & $\begin{array}{l}12.80 \\
12.80 \\
12.80 \\
12.80 \\
12.80 \\
12.80\end{array}$ & $\begin{array}{l}3.57 \\
3.60 \\
3.60 \\
3.60 \\
3.53 \\
3.64\end{array}$ & $\begin{array}{l}1.88 \\
2.00 \\
2.37 \\
2.78 \\
3.22 \\
3.64\end{array}$ & $\begin{array}{l}103.7 \\
104.4 \\
104.4 \\
104.4 \\
102.7 \\
105.4\end{array}$ & $\begin{array}{r}61.4 \\
64.4 \\
73.7 \\
83.9 \\
94.9 \\
105.4\end{array}$ \\
\hline $\begin{array}{c}44 a . * \\
b .\end{array}$ & $\begin{array}{l}73 \\
73\end{array}$ & $\begin{array}{l}73 \\
73\end{array}$ & $\begin{array}{l}12.80 \\
12.80\end{array}$ & $\begin{array}{l}3.60 \\
3.54\end{array}$ & $\begin{array}{l}3.17 \\
3.54\end{array}$ & $\begin{array}{l}104.4 \\
102.9\end{array}$ & $\begin{array}{r}93.7 \\
102.9\end{array}$ \\
\hline
\end{tabular}


II. PERRORMANCE DATA

\begin{tabular}{|c|c|c|c|c|c|c|c|}
\hline \multirow[b]{2}{*}{$\begin{array}{r}\text { Data } \\
\text { Set } \\
\end{array}$} & \multirow{2}{*}{\multicolumn{2}{|c|}{ 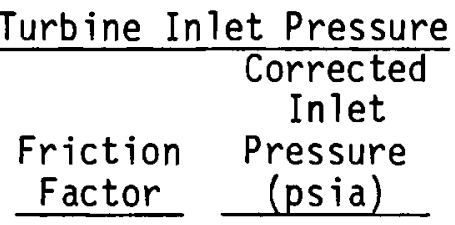 }} & \multicolumn{2}{|c|}{ Flow Rate } & \multicolumn{3}{|c|}{ Load Cell } \\
\hline & & & $\begin{array}{l}\text { Volume } \\
\text { (SCFM }\end{array}$ & $\begin{array}{c}\text { Mass } \\
(1 \mathrm{bm} / \mathrm{sec}) \\
\end{array}$ & $\begin{array}{c}\text { Static } \\
\text { Zero } \\
\end{array}$ & $\begin{array}{c}\text { Excitation } \\
\text { Voltage } \\
(V D C) \\
\end{array}$ & $\begin{array}{c}\text { Output } \\
\text { Voltage } \\
\text { (mV) }\end{array}$ \\
\hline $\begin{array}{c}\text { Ala. } \\
\text { b.* } \\
\text { c. } \\
\text { d. } \\
\text { e. } \\
\text { f. } \\
\text { g. } \\
\text { h. } \\
\text { i. }\end{array}$ & $\begin{array}{l}.0233 \\
.0223 \\
.0209 \\
.0195 \\
.0185 \\
.0180 \\
.0173 \\
.0169\end{array}$ & $\begin{array}{l}28.8 \\
33.7 \\
43.0 \\
51.5 \\
62.2 \\
69.1 \\
80.0 \\
93.5\end{array}$ & $\begin{array}{l}1.6 \\
1.9 \\
2.5 \\
3.2 \\
3.9 \\
4.4 \\
5.1 \\
5.7\end{array}$ & $\begin{array}{l}.00483 \\
.00572 \\
.00755 \\
.00988 \\
.01219 \\
.01386 \\
.01597 \\
.01779\end{array}$ & .552 & $\begin{array}{l}8.43 \\
8.43 \\
8.44 \\
8.44 \\
8.44 \\
8.42 \\
8.44 \\
8.44 \\
8.44\end{array}$ & $\begin{array}{l}.525 \\
.558 \\
.606 \\
.666 \\
.754 \\
.818 \\
.915 \\
.932\end{array}$ \\
\hline $\begin{array}{c}\text { A2a.* } \\
\text { b. } \\
\text { c. } \\
\text { d. } \\
\text { e. } \\
\text { f. } \\
\text { g. }\end{array}$ & $\begin{array}{l}.0205 \\
.0196 \\
.0187 \\
.0179 \\
.0174 \\
.0168\end{array}$ & $\begin{array}{l}44.6 \\
52.0 \\
62.1 \\
71.4 \\
80.0 \\
89.8\end{array}$ & $\begin{array}{l}2.6 \\
3.2 \\
3.8 \\
4.5 \\
5.1 \\
5.8\end{array}$ & $\begin{array}{l}.00811 \\
.00985 \\
.01177 \\
.01401 \\
.01584 \\
.01813\end{array}$ & .541 & $\begin{array}{l}8.44 \\
8.44 \\
8.44 \\
8.44 \\
8.44 \\
8.44 \\
8.44\end{array}$ & $\begin{array}{l}.563 \\
.609 \\
.685 \\
.737 \\
.812 \\
.887\end{array}$ \\
\hline $\begin{array}{l}\text { A3a. } \\
\text { b.* } \\
\text { c. } \\
\text { d. } \\
\text { e. } \\
\text { f. } \\
\text { g. }\end{array}$ & $\begin{array}{l}.0188 \\
.0187 \\
.0181 \\
.0173 \\
.0168 \\
.0165\end{array}$ & $\begin{array}{r}59.1 \\
62.0 \\
71.0 \\
80.6 \\
91.4 \\
101.7\end{array}$ & $\begin{array}{l}3.7 \\
3.8 \\
4.3 \\
5.1 \\
5.7 \\
6.1\end{array}$ & $\begin{array}{l}.01146 \\
.01183 \\
.01347 \\
.01608 \\
.01789 \\
.01943\end{array}$ & .484 & $\begin{array}{l}8.45 \\
8.45 \\
8.45 \\
8.45 \\
8.45 \\
8.45 \\
8.45\end{array}$ & $\begin{array}{l}.563 \\
.600 \\
.630, .660 \\
.730 \\
.760 \\
.790\end{array}$ \\
\hline $\begin{array}{c}\text { A4a.* } \\
\text { b. } \\
\text { c. }\end{array}$ & $\begin{array}{l}.0169 \\
.0165\end{array}$ & $\begin{array}{l}90.1 \\
89.0\end{array}$ & $\begin{array}{l}5.6 \\
6.2\end{array}$ & $\begin{array}{l}.01772 \\
.01954\end{array}$ & .535 & $\begin{array}{l}8.45 \\
8.45 \\
8.45\end{array}$ & $\begin{array}{l}.564 \\
.640\end{array}$ \\
\hline
\end{tabular}




\begin{tabular}{|c|c|c|c|c|c|c|c|}
\hline \multirow[b]{2}{*}{$\begin{array}{r}\text { Data } \\
\text { Set } \\
\end{array}$} & \multirow[b]{2}{*}{$\begin{array}{l}\text { Gross } \\
\text { Force } \\
\text { (1bf) } \\
\end{array}$} & \multirow[b]{2}{*}{$\begin{array}{l}\text { Net } \\
\text { Force } \\
\text { ( Ibf) } \\
\end{array}$} & \multirow[b]{2}{*}{$\begin{array}{c}\text { Torque } \\
\text { (ft-lbf) }\end{array}$} & \multirow[b]{2}{*}{$\begin{array}{l}\text { Speed } \\
\text { (rpm) } \\
\end{array}$} & \\
\hline & & & & & $\begin{array}{c}\text { Measured } \\
\text { Output } \\
\text { (hp) } \\
\end{array}$ & $\begin{array}{c}\text { Theoretical } \\
\text { Input } \\
\text { (hp) } \\
\end{array}$ & $\begin{array}{c}\text { Efficiency } \\
(\%)\end{array}$ \\
\hline $\begin{array}{l}\text { Ala. } \\
\text { b.* } \\
\text { c. } \\
\text { d. } \\
\text { e. } \\
\text { f. } \\
\text { g. } \\
\text { h. } \\
\text { i. }\end{array}$ & $\begin{array}{l}.104 \\
.110 \\
.120 \\
.132 \\
.149 \\
.162 \\
.181 \\
.184\end{array}$ & $\begin{array}{l}.0108 \\
.017 \\
.027 \\
.039 \\
.056 \\
.069 \\
.088 \\
.091\end{array}$ & $\begin{array}{l}.005 \\
.008 \\
.013 \\
.019 \\
.027 \\
.033 \\
.042 \\
.043\end{array}$ & $\begin{array}{l}10000 \\
10000 \\
10000 \\
10000 \\
10000 \\
10000 \\
10000 \\
10000\end{array}$ & $\begin{array}{l}.0098 \\
.0155 \\
.0241 \\
.0385 \\
.0508 \\
.0619 \\
.0792 \\
.0822\end{array}$ & $\begin{array}{l}.158 \\
.225 \\
.371 \\
.611 \\
.758 \\
.910 \\
1.13 \\
1.35\end{array}$ & $\begin{array}{l}6.2 \\
6.9 \\
6.5 \\
6.3 \\
6.7 \\
6.8 \\
7.0 \\
6.1\end{array}$ \\
\hline $\begin{array}{c}\text { A2a. } \\
\text { b. } \\
\text { c. } \\
\text { d. } \\
\text { e. } \\
\text { f. } \\
\text { g. }\end{array}$ & $\begin{array}{l}.111 \\
.120 \\
.135 \\
.146 \\
.160 \\
.175\end{array}$ & $\begin{array}{l}.021 \\
.030 \\
.045 \\
.056 \\
.070 \\
.085\end{array}$ & $\begin{array}{l}.010 \\
.014 \\
.021 \\
.027 \\
.033 \\
.040\end{array}$ & $\begin{array}{l}20000 \\
20000 \\
20000 \\
20000 \\
20000 \\
20000\end{array}$ & $\begin{array}{l}.0766 \\
.0548 \\
.0819 \\
.1003 \\
.1270 \\
.1540\end{array}$ & $\begin{array}{l}.815 \\
.554 \\
.731 \\
.946 \\
1.11 \\
1.34\end{array}$ & $\begin{array}{r}9.4 \\
9.9 \\
11.2 \\
10.6 \\
11.4 \\
11.5\end{array}$ \\
\hline $\begin{array}{c}\text { A3a. } \\
\text { b.* } \\
\text { c. } \\
\text { d. } \\
\text { e. } \\
\text { f. } \\
\text { g. }\end{array}$ & $\begin{array}{l}.111 \\
.118 \\
.124 \\
.130 \\
.144 \\
.150 \\
.156\end{array}$ & $\begin{array}{l}.002 \\
.010 \\
.016 \\
.022 \\
.036 \\
.042 \\
.048\end{array}$ & $\begin{array}{l}.001 \\
.005 \\
.008 \\
.010 \\
.017 \\
.020 \\
.023\end{array}$ & $\begin{array}{l}30000 \\
30000 \\
30000 \\
30000 \\
30000 \\
30000 \\
30000\end{array}$ & $\begin{array}{l}.0054 \\
.0279 \\
.0442 \\
.0602 \\
.0976 \\
.1136 \\
.1296\end{array}$ & $\begin{array}{c}.692 \\
.734 \\
.902 \\
.899 \\
1.13 \\
1.34 \\
1.51\end{array}$ & $\begin{array}{l}.78 \\
3.8 \\
4.9 \\
6.7 \\
8.6 \\
8.5 \\
8.6\end{array}$ \\
\hline $\begin{array}{c}\text { A4a.* } \\
\text { b. } \\
\text { c. }\end{array}$ & $\begin{array}{l}.011 \\
.126\end{array}$ & $\begin{array}{l}.006 \\
.021\end{array}$ & $\begin{array}{l}.003 \\
.010\end{array}$ & $\begin{array}{l}40000 \\
40000\end{array}$ & $\begin{array}{l}.0224 \\
.0766\end{array}$ & $\begin{array}{l}1.32 \\
1.45\end{array}$ & $\begin{array}{l}1.7 \\
5.3\end{array}$ \\
\hline
\end{tabular}


II. PERFORMANCE DATA

\begin{tabular}{|c|c|c|c|c|c|c|c|}
\hline \multirow[b]{3}{*}{ Set } & \multicolumn{2}{|c|}{ Air Temperature } & \multicolumn{5}{|c|}{ Pressure } \\
\hline & \multirow[b]{2}{*}{$\begin{array}{c}\text { Rotameter } \\
\text { Inlet } \\
\left({ }^{\circ} \mathrm{F}\right) \\
\end{array}$} & \multirow[b]{2}{*}{$\begin{array}{c}\text { Turbine } \\
\text { Inlet } \\
\text { (OF) } \\
\end{array}$} & \multicolumn{3}{|c|}{ Output Voltages } & \multirow[b]{2}{*}{$\begin{array}{c}\text { Rotameter } \\
\text { Inlet } \\
\text { (psia) } \\
\end{array}$} & \multirow[b]{2}{*}{$\begin{array}{c}\text { Turbine } \\
\text { Inlet } \\
\text { (psia) }\end{array}$} \\
\hline & & & $\begin{array}{l}\text { Transducer } \\
\text { Excitation } \\
\text { Voltage } \\
\text { (V DC) } \\
\end{array}$ & $\begin{array}{c}\text { Rotameter } \\
\text { Inlet } \\
\text { (V) } \\
\end{array}$ & $\begin{array}{c}\text { Turbine } \\
\text { Inlet } \\
\text { (V) } \\
\end{array}$ & & \\
\hline \multicolumn{8}{|l|}{ A5a. } \\
\hline b. * & 73 & 73 & 12.50 & 3.97 & .532 & 113.7 & 27.7 \\
\hline c. & 73 & 73 & 12.50 & 3.88 & .790 & 111.4 & 34.2 \\
\hline d. & 73 & 73 & 12.50 & 3.59 & 1.18 & 104.2 & 43.9 \\
\hline e. & 73 & 73 & 12.50 & 3.57 & 1.61 & 103.7 & 54.7 \\
\hline f. & 73 & 73 & 12.50 & 3.62 & 2.02 & 104.9 & 64.9 \\
\hline$g$. & 73 & 73 & 12.50 & 3.56 & 2.42 & 103.4 & 74.9 \\
\hline h. & 73 & 73 & 12.50 & 3.53 & 2.77 & 102.7 & 83.7 \\
\hline i. & 74 & 74 & 12.50 & 3.45 & 3.14 & 100.7 & 92.9 \\
\hline \multicolumn{8}{|l|}{ A6a. } \\
\hline b.* & 73 & 73 & 12.50 & 3.86 & 1.09 & 110.9 & 41.7 \\
\hline c. & 73 & 73 & 12.50 & 3.72 & 1.65 & 107.4 & 55.7 \\
\hline d. & 73 & 73 & 12.50 & 3.73 & 2.05 & 107.7 & 65.7 \\
\hline e. & 74 & 74 & 12.50 & 3.55 & 2.36 & 103.2 & 73.4 \\
\hline f. & 74 & 74 & 12.50 & 3.70 & 2.90 & 106.9 & 86.9 \\
\hline g. & 73 & 73 & 12.50 & 3. & 3.20 & 101.9 & 94.4 \\
\hline & 74 & 74 & 12.50 & & 3.52 & 102.7 & 102.4 \\
\hline
\end{tabular}


II. PERFORMANCE DATA

\begin{tabular}{|c|c|c|c|c|c|c|c|}
\hline \multirow[b]{2}{*}{$\begin{array}{r}\text { Data } \\
\text { Set } \\
\end{array}$} & \multicolumn{2}{|c|}{ urbine Inlet Pressure } & \multicolumn{2}{|c|}{ Flow Rate } & \multicolumn{3}{|c|}{ Load Cell } \\
\hline & $\begin{array}{c}\text { Friction } \\
\text { Factor } \\
\end{array}$ & $\begin{array}{l}\text { Corrected } \\
\text { Inlet } \\
\text { Pressure } \\
\text { (psia) } \\
\end{array}$ & $\begin{array}{l}\text { Volume } \\
\left(\text { SCFM }_{0}\right)\end{array}$ & $\begin{array}{c}\text { Mass } \\
(1 \mathrm{bm} / \mathrm{sec})\end{array}$ & $\begin{array}{c}\text { Static } \\
\text { Zero } \\
\end{array}$ & $\begin{array}{c}\text { Excitation } \\
\text { Voltage } \\
(V D C) \\
\end{array}$ & $\begin{array}{l}\text { Output } \\
\text { Voltage } \\
\text { (mv) }\end{array}$ \\
\hline $\begin{array}{c}\text { A5a. } \\
\text { b.* } \\
\text { c. } \\
\text { d. } \\
\text { e. } \\
\text { f. } \\
\text { g. } \\
\text { h. } \\
\text { i. }\end{array}$ & $\begin{array}{l}.0242 \\
.0227 \\
.0209 \\
.0196 \\
.0187 \\
.0180 \\
.0172 \\
.0170\end{array}$ & $\begin{array}{l}26.7 \\
33.2 \\
42.4 \\
52.7 \\
62.6 \\
72.2 \\
80.3 \\
89.5\end{array}$ & $\begin{array}{l}1.4 \\
1.8 \\
2.5 \\
3.2 \\
3.8 \\
4.4 \\
5.2 \\
5.6\end{array}$ & $\begin{array}{l}.00416 \\
.00547 \\
.00757 \\
.00983 \\
.01186 \\
.01373 \\
.01627 \\
.01738\end{array}$ & .568 & $\begin{array}{l}8.47 \\
8.47 \\
8.47 \\
8.47 \\
8.47 \\
8.47 \\
8.47 \\
8.47 \\
8.47\end{array}$ & $\begin{array}{l}.535 \\
.565 \\
.611 \\
.674 \\
.750 \\
.805 \\
.880 \\
.900\end{array}$ \\
\hline $\begin{array}{l}\text { A6a. } \\
\text { b.* } \\
\text { c. } \\
\text { d. } \\
\text { e. } \\
\text { f. } \\
\text { g. } \\
\text { h. }\end{array}$ & $\begin{array}{l}.0212 \\
.0195 \\
.0185 \\
.0181 \\
.0173 \\
.0169 \\
.0166\end{array}$ & $\begin{array}{l}40.3 \\
53.7 \\
63.1 \\
72.8 \\
83.7 \\
90.9 \\
98.7\end{array}$ & $\begin{array}{l}2.3 \\
3.2 \\
3.9 \\
4.3 \\
5.1 \\
5.7 \\
6.1\end{array}$ & $\begin{array}{l}.00714 \\
.01001 \\
.01235 \\
.01337 \\
.01626 \\
.01783 \\
.01917\end{array}$ & .568 & $\begin{array}{l}8.47 \\
8.47 \\
8.47 \\
8.47 \\
8.47 \\
8.47 \\
8.47 \\
8.47\end{array}$ & $\begin{array}{l}.555 \\
.610 \\
.670 \\
.715 \\
.790 \\
.825 \\
.865\end{array}$ \\
\hline
\end{tabular}


II. PERFORMANCE DATA

\begin{tabular}{|c|c|c|c|c|c|c|c|}
\hline $\begin{array}{r}\text { Data } \\
\text { Set }\end{array}$ & $\begin{array}{l}\text { Gross } \\
\text { Force } \\
\text { (1bf) }\end{array}$ & $\begin{array}{l}\text { Net } \\
\text { Force } \\
\text { (1bf) } \\
\end{array}$ & $\begin{array}{l}\text { Torque } \\
\text { (ft-1bf) }\end{array}$ & $\begin{array}{l}\text { Speed } \\
\text { (rpm) } \\
\end{array}$ & $\begin{array}{c}\text { Measured } \\
\text { Output } \\
\text { (hp) } \\
\end{array}$ & $\begin{array}{c}\text { Theoretical } \\
\text { Input } \\
\text { (hp) }\end{array}$ & $\begin{array}{c}\text { Efficiency } \\
(\%)\end{array}$ \\
\hline $\begin{array}{c}\text { A5a. } \\
\text { b.* } \\
\text { c. } \\
\text { d. } \\
\text { e. } \\
\text { f. } \\
\text { g. } \\
\text { h. } \\
\text { i. }\end{array}$ & $\begin{array}{l}.105 \\
.111 \\
.120 \\
.133 \\
.148 \\
.158 \\
.173 \\
.177\end{array}$ & $\begin{array}{l}.012 \\
.018 \\
.027 \\
.040 \\
.055 \\
.065 \\
.080 \\
.084\end{array}$ & $\begin{array}{l}.006 \\
.009 \\
.013 \\
.019 \\
.026 \\
.031 \\
.038 \\
.040\end{array}$ & $\begin{array}{l}10000 \\
10000 \\
10000 \\
10000 \\
10000 \\
10000 \\
10000 \\
10000\end{array}$ & $\begin{array}{l}.0108 \\
.0163 \\
.0244 \\
.0361 \\
.0497 \\
.0587 \\
.0723 \\
.0759\end{array}$ & $\begin{array}{c}.123 \\
.212 \\
.364 \\
.555 \\
.742 \\
.917 \\
1.15 \\
1.29\end{array}$ & $\begin{array}{l}8.8 \\
7.7 \\
6.7 \\
6.5 \\
6.7 \\
6.4 \\
6.3 \\
5.9\end{array}$ \\
\hline $\begin{array}{c}\text { A6a. } \\
\text { b.* } \\
\text { c. } \\
\text { d. } \\
\text { e. } \\
\text { f. } \\
\text { g. } \\
\text { h. }\end{array}$ & $\begin{array}{l}.109 \\
.120 \\
.132 \\
.141 \\
.155 \\
.162 \\
.170\end{array}$ & $\begin{array}{l}.019 \\
.030 \\
.042 \\
.051 \\
.065 \\
.072 \\
.080\end{array}$ & $\begin{array}{l}.009 \\
.014 \\
.020 \\
.024 \\
.031 \\
.034 \\
.038\end{array}$ & $\begin{array}{l}20000 \\
20000 \\
20000 \\
20000 \\
20000 \\
20000 \\
20000\end{array}$ & $\begin{array}{l}.0343 \\
.0542 \\
.0759 \\
.0922 \\
.1175 \\
.1301 \\
.1446\end{array}$ & $\begin{array}{l}.033 \\
.571 \\
.774 \\
.904 \\
1.18 \\
1.33 \\
1.48\end{array}$ & $\begin{array}{r}10.3 \\
9.5 \\
9.8 \\
10.2 \\
10.0 \\
9.8 \\
9.8\end{array}$ \\
\hline
\end{tabular}


II. PERFORMANCE DATA

\begin{tabular}{|c|c|c|c|c|c|c|c|}
\hline \multirow[b]{2}{*}{$\begin{array}{l}\text { Data } \\
\text { Set } \\
\end{array}$} & \multicolumn{2}{|c|}{ A ir Temperature } & \multicolumn{5}{|c|}{$\begin{array}{r}\text { Pressure } \\
\end{array}$} \\
\hline & $\begin{array}{c}\text { Rotameter } \\
\text { Inlet } \\
\text { (OF) } \\
\end{array}$ & $\begin{array}{c}\text { Turbine } \\
\text { Inlet } \\
\text { (OF) } \\
\end{array}$ & $\begin{array}{l}\text { Transducer } \\
\text { Excitation } \\
\text { Voltage } \\
(V \text { DC }) \\
\end{array}$ & $\begin{array}{c}\text { Rotameter } \\
\text { Inlet } \\
\text { (V) } \\
\end{array}$ & $\begin{array}{c}\text { Turbine } \\
\text { Inlet } \\
\text { (V) } \\
\end{array}$ & $\begin{array}{c}\text { Rotameter } \\
\text { Inlet } \\
\text { (psia) } \\
\end{array}$ & $\begin{array}{l}\text { Turbine } \\
\text { Inlet } \\
\text { (psia) } \\
\end{array}$ \\
\hline $\begin{array}{c}\text { B1a. } \\
\text { b.* } \\
\text { c.* } \\
\text { d. } \\
\text { e. } \\
\text { f. } \\
\text { g. } \\
\text { h. } \\
i . \\
\text { j. } \\
\text { k. } \\
\text { l. } \\
\text { m. } \\
\text { n. } \\
\text { o. } \\
\text { p. } \\
\text { q. } \\
\text { r. } \\
\text { s. }\end{array}$ & $\begin{array}{l}73 \\
72 \\
73 \\
72 \\
72 \\
72 \\
72 \\
72 \\
72 \\
72 \\
72 \\
72 \\
72 \\
73 \\
73 \\
73 \\
73 \\
73\end{array}$ & $\begin{array}{l}73 \\
72 \\
72 \\
72 \\
72 \\
72 \\
72 \\
72 \\
72 \\
72 \\
72 \\
72 \\
72 \\
73 \\
73 \\
73 \\
73 \\
73\end{array}$ & $\begin{array}{l}12.69 \\
12.69 \\
12.69 \\
12.69 \\
12.69 \\
12.69 \\
12.69 \\
12.69 \\
12.69 \\
12.69 \\
12.69 \\
12.69 \\
12.69 \\
12.69 \\
12.69 \\
12.69 \\
12.69 \\
12.69\end{array}$ & $\begin{array}{l}4.00 \\
4.06 \\
3.90 \\
3.97 \\
3.86 \\
3.73 \\
3.57 \\
3.60 \\
3.60 \\
3.55 \\
3.55 \\
3.54 \\
3.49 \\
3.50 \\
3.60 \\
3.60 \\
3.60 \\
3.59\end{array}$ & $\begin{array}{l}.270 \\
.247 \\
.418 \\
.414 \\
.810 \\
.777 \\
1.18 \\
1.19 \\
1.17 \\
1.60 \\
1.97 \\
1.97 \\
2.36 \\
2.37 \\
2.90 \\
2.94 \\
3.27 \\
3.28\end{array}$ & $\begin{array}{l}114.4 \\
115.9 \\
111.9 \\
113.6 \\
110.9 \\
107.6 \\
103.6 \\
104.4 \\
104.4 \\
103.1 \\
103.1 \\
102.9 \\
101.6 \\
101.9 \\
104.4 \\
104.4 \\
104.4 \\
104.1\end{array}$ & $\begin{array}{l}21.1 \\
20.5 \\
24.8 \\
24.7 \\
34.6 \\
33.8 \\
43.9 \\
44.2 \\
43.6 \\
54.3 \\
63.6 \\
63.5 \\
73.3 \\
73.6 \\
86.9 \\
87.9 \\
96.0 \\
94.8\end{array}$ \\
\hline $\begin{array}{c}\text { B2a.* } \\
\text { b.* } \\
\text { c. } \\
\text { d. } \\
\text { e. } \\
\text { f. } \\
\text { g. } \\
\text { h. } \\
\text { i. } \\
\text { j. } \\
\text { k. } \\
\text { l. } \\
\text { m. } \\
\text { n. }\end{array}$ & $\begin{array}{l}73 \\
73 \\
72 \\
72 \\
72 \\
73 \\
73 \\
73 \\
73 \\
73 \\
73 \\
73 \\
73 \\
73\end{array}$ & $\begin{array}{l}73 \\
73 \\
72 \\
72 \\
72 \\
73 \\
73 \\
73 \\
73 \\
73 \\
73 \\
73 \\
73 \\
73\end{array}$ & $\begin{array}{l}12.69 \\
12.69 \\
12.69 \\
12.69 \\
12.69 \\
12.69 \\
12.69 \\
12.68 \\
12.68 \\
12.68 \\
12.68 \\
12.68 \\
12.68 \\
12.68\end{array}$ & $\begin{array}{l}3.92 \\
3.91 \\
3.76 \\
3.73 \\
3.58 \\
3.53 \\
3.59 \\
3.64 \\
3.51 \\
3.53 \\
3.48 \\
3.51 \\
3.52 \\
3.44\end{array}$ & $\begin{array}{l}.889 \\
.865 \\
1.22 \\
1.21 \\
1.60 \\
1.58 \\
2.01 \\
2.04 \\
2.35 \\
2.37 \\
2.80 \\
2.83 \\
3.14 \\
3.14\end{array}$ & $\begin{array}{l}112.4 \\
112.1 \\
108.4 \\
107.6 \\
103.9 \\
102.6 \\
104.1 \\
105.4 \\
102.1 \\
102.6 \\
101.4 \\
102.1 \\
102.4 \\
100.4\end{array}$ & $\begin{array}{l}36.6 \\
36.0 \\
44.8 \\
44.6 \\
54.2 \\
53.8 \\
64.6 \\
65.4 \\
73.1 \\
73.5 \\
84.2 \\
85.0 \\
92.8 \\
92.8\end{array}$ \\
\hline
\end{tabular}


II. PERFORMANCE DATA

\begin{tabular}{|c|c|c|c|c|c|c|c|}
\hline \multirow[b]{2}{*}{$\begin{array}{r}\text { Data } \\
\text { Set } \\
\end{array}$} & \multirow{2}{*}{\multicolumn{2}{|c|}{ 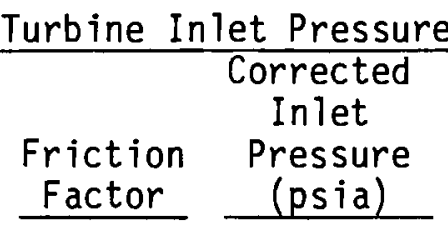 }} & \multicolumn{2}{|c|}{ Flow Rate } & \multicolumn{3}{|c|}{ Load Cell } \\
\hline & & & $\begin{array}{l}\text { Volume } \\
\text { (SCFM } 0)\end{array}$ & $\begin{array}{c}\text { Mass } \\
(1 \mathrm{bm} / \mathrm{sec})\end{array}$ & $\begin{array}{c}\text { Static } \\
\text { Zero } \\
\end{array}$ & $\begin{array}{c}\text { Excitation } \\
\text { Voltage } \\
(V D C) \\
\end{array}$ & $\begin{array}{c}\text { Output } \\
\text { Voltage } \\
(\mathrm{mv})\end{array}$ \\
\hline $\begin{array}{c}\text { Bla. } \\
\text { b.* } \\
\text { c.* } \\
\text { d. } \\
\text { e. } \\
\text { f. } \\
\text { g. } \\
\text { h. } \\
i . \\
\text { j. } \\
\text { k. } \\
\text { l. } \\
\text { m. } \\
\text { n. } \\
\text { o. } \\
\text { p. } \\
\text { q. } \\
\text { r. } \\
\text { s. }\end{array}$ & $\begin{array}{l}.0277 \\
.0276 \\
.0248 \\
.0248 \\
.0223 \\
.0224 \\
.0209 \\
.0207 \\
.0194 \\
.0196 \\
.0187 \\
.0187 \\
.0179 \\
.0180 \\
.0173 \\
.0173 \\
.0169 \\
.0169\end{array}$ & $\begin{array}{l}20.7 \\
20.1 \\
24.1 \\
24.0 \\
33.5 \\
32.6 \\
42.4 \\
42.5 \\
41.0 \\
52.3 \\
61.2 \\
61.1 \\
70.5 \\
70.9 \\
83.7 \\
84.7 \\
92.5 \\
91.3\end{array}$ & $\begin{array}{l}0.9 \\
0.9 \\
1.3 \\
1.3 \\
1.9 \\
1.9 \\
2.5 \\
2.6 \\
3.3 \\
3.2 \\
3.8 \\
3.8 \\
4.5 \\
4.4 \\
5.1 \\
5.1 \\
5.6 \\
5.6\end{array}$ & $\begin{array}{l}.0025 \\
.0025 \\
.0038 \\
.0038 \\
.0058 \\
.0057 \\
.0075 \\
.0079 \\
.0102 \\
.0098 \\
.0117 \\
.0117 \\
.0139 \\
.0136 \\
.0160 \\
.0160 \\
.0177 \\
.0176\end{array}$ & .429 & $\begin{array}{l}8.46 \\
8.46 \\
8.46 \\
8.46 \\
8.46 \\
8.46 \\
8.46 \\
8.46 \\
8.46 \\
8.46 \\
8.46 \\
8.46 \\
8.46 \\
8.46 \\
8.46 \\
8.46 \\
8.46 \\
8.46 \\
8.46\end{array}$ & $\begin{array}{l}.460 \\
.468 \\
.485 \\
.485 \\
.550 \\
.545 \\
.640 \\
.605 \\
.655 \\
.685 \\
.785 \\
.770 \\
.880 \\
.880 \\
.938 \\
.935 \\
1.030 \\
1.045\end{array}$ \\
\hline $\begin{array}{c}\text { B2a.* } \\
\text { b.* } \\
\text { c. } \\
\text { d. } \\
\text { e. } \\
\text { f. } \\
\text { g. } \\
\text { h. } \\
\text { i. } \\
\text { j. } \\
\text { k. } \\
\text { l. } \\
\text { m. } \\
\text { n. }\end{array}$ & $\begin{array}{l}.0220 \\
.0220 \\
.0208 \\
.0208 \\
.0196 \\
.0194 \\
.0187 \\
.0187 \\
.0179 \\
.0179 \\
.0173 \\
.0173 \\
.0168 \\
.0168\end{array}$ & $\begin{array}{l}35.4 \\
34.7 \\
43.2 \\
43.0 \\
52.2 \\
51.7 \\
62.2 \\
63.0 \\
70.2 \\
70.6 \\
80.9 \\
81.7 \\
89.1 \\
89.1\end{array}$ & $\begin{array}{l}2.0 \\
2.0 \\
2.5 \\
2.5 \\
3.2 \\
3.3 \\
3.8 \\
3.8 \\
4.5 \\
4.5 \\
5.2 \\
5.2 \\
5.8 \\
5.8\end{array}$ & $\begin{array}{l}.0061 \\
.0061 \\
.0077 \\
.0077 \\
.0098 \\
.0101 \\
.0118 \\
.0119 \\
.0139 \\
.0140 \\
.0161 \\
.0162 \\
.0181 \\
.0180\end{array}$ & & $\begin{array}{l}8.46 \\
8.46 \\
8.46 \\
8.46 \\
8.46 \\
8.46 \\
8.46 \\
8.46 \\
8.46 \\
8.46 \\
8.46 \\
8.46 \\
8.46 \\
8.46\end{array}$ & $\begin{array}{l}.485 \\
.494 \\
.520 \\
.540 \\
.580 \\
.590 \\
.680 \\
.690 \\
.720 \\
.745 \\
.810 \\
.845 \\
.935 \\
.930\end{array}$ \\
\hline
\end{tabular}


II. PERFORMANCE DATA

\begin{tabular}{|c|c|c|c|c|c|c|c|}
\hline \multirow[b]{2}{*}{$\begin{array}{l}\text { Data } \\
\text { Set }\end{array}$} & \multirow[b]{2}{*}{$\begin{array}{l}\text { Gross } \\
\text { Force } \\
\text { (1bf) } \\
\end{array}$} & \multirow[b]{2}{*}{$\begin{array}{l}\text { Net } \\
\text { Force } \\
\text { (1bf) }\end{array}$} & \multirow[b]{2}{*}{$\begin{array}{c}\text { Torque } \\
(f t-1 b f)\end{array}$} & \multirow[b]{2}{*}{$\begin{array}{l}\text { Speed } \\
\text { (rpm) }\end{array}$} & \multicolumn{3}{|c|}{ 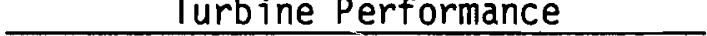 } \\
\hline & & & & & $\begin{array}{c}\text { Measured } \\
\text { Output } \\
\text { (hp) } \\
\end{array}$ & $\begin{array}{c}\text { Theoretical } \\
\text { Input } \\
\text { (hp) }\end{array}$ & $\begin{array}{c}\text { Efficiency } \\
(\%)\end{array}$ \\
\hline $\begin{array}{c}\text { Bla. } \\
\text { b.* } \\
\text { c.* } \\
\text { d. } \\
\text { e. } \\
\text { f. } \\
\text { g. } \\
\text { h. } \\
i . \\
\text { j. } \\
\text { k. } \\
\text { l. } \\
\text { m. } \\
\text { n. } \\
\text { o. } \\
\text { p. } \\
\text { q. } \\
\text { r. } \\
\text { s. }\end{array}$ & $\begin{array}{l}.091 \\
.092 \\
.096 \\
.096 \\
.108 \\
.107 \\
.126 \\
.119 \\
.129 \\
.135 \\
.155 \\
.152 \\
.173 \\
.173 \\
.185 \\
.184 \\
.203 \\
.206\end{array}$ & $\begin{array}{l}.006 \\
.007 \\
.011 \\
.011 \\
.023 \\
.022 \\
.041 \\
.034 \\
.044 \\
.050 \\
.070 \\
.067 \\
.088 \\
.088 \\
.100 \\
.099 \\
.118 \\
.121\end{array}$ & $\begin{array}{l}.003 \\
.003 \\
.005 \\
.005 \\
.011 \\
.010 \\
.019 \\
.016 \\
.021 \\
.024 \\
.033 \\
.032 \\
.042 \\
.042 \\
.047 \\
.047 \\
.056 \\
.057\end{array}$ & $\begin{array}{l}10000 \\
10000 \\
10000 \\
10000 \\
10000 \\
10000 \\
10000 \\
10000 \\
10000 \\
10000 \\
10000 \\
10000 \\
10000 \\
10000 \\
10000 \\
10000 \\
10000 \\
10000\end{array}$ & $\begin{array}{l}.0054 \\
.0063 \\
.0099 \\
.0099 \\
.0208 \\
.0199 \\
.0370 \\
.0307 \\
.0398 \\
.0452 \\
.0633 \\
.0605 \\
.0795 \\
.0795 \\
.0904 \\
.0895 \\
.1066 \\
.1093\end{array}$ & $\begin{array}{l}.045 \\
.041 \\
.0943 \\
.0934 \\
.226 \\
.216 \\
.359 \\
.379 \\
.480 \\
.545 \\
.719 \\
.720 \\
.914 \\
.903 \\
1.14 \\
1.15 \\
1.32 \\
1.30\end{array}$ & $\begin{array}{r}12.0 \\
15.2 \\
10.5 \\
10.6 \\
9.2 \\
9.2 \\
10.3 \\
8.1 \\
8.3 \\
8.3 \\
8.8 \\
8.4 \\
8.7 \\
8.8 \\
7.9 \\
7.8 \\
8.1 \\
8.4\end{array}$ \\
\hline $\begin{array}{c}\text { B2a.* } \\
\text { b.* } \\
\text { c. } \\
\text { d. } \\
\text { e. } \\
\text { f. } \\
\text { g. } \\
\text { h. } \\
\text { i. } \\
\text { j. } \\
\text { k. } \\
\text { l. } \\
\text { m. } \\
\text { n. }\end{array}$ & $\begin{array}{l}.096 \\
.097 \\
.102 \\
.106 \\
.114 \\
.116 \\
.134 \\
.136 \\
.142 \\
.147 \\
.160 \\
.166 \\
.184 \\
.183\end{array}$ & $\begin{array}{l}.011 \\
.012 \\
.017 \\
.021 \\
.029 \\
.031 \\
.049 \\
.051 \\
.057 \\
.062 \\
.075 \\
.081 \\
.099 \\
.098\end{array}$ & $\begin{array}{l}.005 \\
.006 \\
.008 \\
.010 \\
.014 \\
.015 \\
.023 \\
.024 \\
.027 \\
.029 \\
.036 \\
.038 \\
.047 \\
.047\end{array}$ & $\begin{array}{l}20000 \\
20000 \\
20000 \\
20000 \\
20000 \\
20000 \\
20000 \\
20000 \\
20000 \\
20000 \\
20000 \\
20000 \\
20000 \\
20000\end{array}$ & $\begin{array}{l}.0199 \\
.0217 \\
.0307 \\
.0380 \\
.0524 \\
.0560 \\
.0886 \\
.0922 \\
.1030 \\
.1120 \\
.1355 \\
.1464 \\
.1789 \\
.1771\end{array}$ & $\begin{array}{l}.252 \\
.247 \\
.374 \\
.376 \\
.546 \\
.560 \\
.732 \\
.744 \\
.920 \\
.926 \\
1.14 \\
1.15 \\
1.34 \\
1.32\end{array}$ & $\begin{array}{r}7.9 \\
8.8 \\
8.2 \\
10.1 \\
9.6 \\
10.0 \\
12.1 \\
12.4 \\
11.2 \\
12.1 \\
11.9 \\
12.7 \\
13.4 \\
13.4\end{array}$ \\
\hline
\end{tabular}


II. PERFORMANCE DATA

\begin{tabular}{|c|c|c|c|c|c|c|c|}
\hline \multirow[b]{3}{*}{$\begin{array}{l}\text { Data } \\
\text { Set }\end{array}$} & \multicolumn{2}{|c|}{ Air Temperature } & \multicolumn{5}{|c|}{ Pressure } \\
\hline & \multirow[b]{2}{*}{$\begin{array}{c}\text { Rotameter } \\
\text { Inlet } \\
\text { (OF) } \\
\end{array}$} & \multirow[b]{2}{*}{$\begin{array}{c}\text { Turbine } \\
\text { Inlet } \\
\text { (OF) }\end{array}$} & \multicolumn{3}{|c|}{ Output Voltages } & \multirow[b]{2}{*}{$\begin{array}{c}\text { Rotameter } \\
\text { Inlet } \\
\text { (psia) } \\
\end{array}$} & \multirow[b]{2}{*}{$\begin{array}{l}\text { Turbine } \\
\text { Inlet } \\
\text { (psia) } \\
\end{array}$} \\
\hline & & & $\begin{array}{c}\text { Transducer } \\
\text { Excitation } \\
\text { Voltage } \\
\text { (V DC) } \\
\end{array}$ & $\begin{array}{c}\text { Rotameter } \\
\text { Inlet } \\
\text { (V) } \\
\end{array}$ & $\begin{array}{l}\text { Turbine } \\
\text { Inlet } \\
\text { (V) }\end{array}$ & & \\
\hline B3a.* & 73 & 73 & 12.68 & 3.81 & 1.74 & 109.6 & 57.7 \\
\hline b.* & 73 & 73 & 12.68 & 3.80 & 1.72 & 109.4 & 57.4 \\
\hline c. & 73 & 73 & 12.68 & 3.60 & 2.00 & 104.4 & 64.4 \\
\hline d. & 73 & 73 & 12.68 & 3.68 & 2.05 & 106.4 & 65.5 \\
\hline e. & 73 & 73 & 12.68 & 3.62 & 2.43 & 104.9 & 75.1 \\
\hline f. & 73 & 73 & 12.68 & 3.59 & 2.42 & 104.1 & 74.8 \\
\hline g. & 73 & 73 & 12.68 & 3.55 & 2.79 & 103.1 & 84.1 \\
\hline h. & 73 & 73 & 12.68 & 3.53 & 2.76 & 102.6 & 83.4 \\
\hline$i$. & 73 & 73 & 12.6 & 3.55 & 3.21 & 103 & 94.5 \\
\hline j. & 73 & 73 & 12.6 & 3.6 & 3.31 & 105.6 & 97.0 \\
\hline B4a.* & 73 & 73 & 12.68 & 3.67 & 2.78 & 106.1 & 83.8 \\
\hline b.* & 73 & 73 & 12.68 & 3.69 & 2.78 & & \\
\hline c. & 73 & 73 & 12.68 & 2.51 & 3.15 & 102.1 & 93.2 \\
\hline d. & 73 & 73 & 12.68 & 3.62 & 3.19 & 104.9 & 94.1 \\
\hline e. $\star \star$ & 73 & 73 & 12.68 & 3.57 & 3.54 & 103.6 & 102.9 \\
\hline 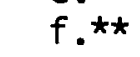 & 73 & 73 & 12.68 & 3.66 & 3.62 & 105.9 & 104.9 \\
\hline
\end{tabular}


II. PERFORMANCE DATA

\begin{tabular}{|c|c|c|c|c|c|c|c|}
\hline \multirow[b]{2}{*}{$\begin{array}{l}\text { Data } \\
\text { Set } \\
\end{array}$} & \multicolumn{2}{|c|}{ urbine Inlet } & \multicolumn{2}{|c|}{ Flow Rate } & \multicolumn{3}{|c|}{ Load Cell } \\
\hline & $\begin{array}{l}\text { Friction } \\
\text { Factor } \\
\end{array}$ & $\begin{array}{l}\text { Inlet } \\
\text { Pressure } \\
\text { (psia) }\end{array}$ & $\begin{array}{l}\text { Vo lume } \\
\text { (SCFM })\end{array}$ & $\begin{array}{c}\text { Mass } \\
(1 \mathrm{bm} / \mathrm{sec}) \\
\end{array}$ & $\begin{array}{c}\text { Static } \\
\text { Zero } \\
\end{array}$ & $\begin{array}{c}\text { Excitation } \\
\text { Voltage } \\
(V D C) \\
\end{array}$ & $\begin{array}{l}\text { Output } \\
\text { Voltage } \\
\text { (mv) }\end{array}$ \\
\hline $\begin{array}{c}\text { B3a.* } \\
\text { b.* } \\
\text { c. } \\
\text { d. } \\
\text { e. } \\
\text { f. } \\
\text { g. } \\
\text { h. } \\
\text { i. } \\
\text { j. }\end{array}$ & $\begin{array}{l}.0193 \\
.0193 \\
.0187 \\
.0186 \\
.0180 \\
.0180 \\
.0173 \\
.0173 \\
.0169 \\
.0169\end{array}$ & $\begin{array}{l}55.6 \\
55.3 \\
62.0 \\
63.1 \\
72.4 \\
72.0 \\
80.9 \\
80.2 \\
91.0 \\
93.5\end{array}$ & $\begin{array}{l}3.3 \\
3.3 \\
3.8 \\
3.8 \\
4.4 \\
4.4 \\
5.1 \\
5.1 \\
5.6 \\
5.6\end{array}$ & $\begin{array}{l}.0104 \\
.0104 \\
.0118 \\
.0119 \\
.0138 \\
.0137 \\
.0159 \\
.0159 \\
.0176 \\
.0178\end{array}$ & & $\begin{array}{l}8.46 \\
8.46 \\
8.46 \\
8.46 \\
8.46 \\
8.46 \\
8.46 \\
8.46 \\
8.46 \\
8.46\end{array}$ & $\begin{array}{l}.565 \\
.560 \\
.610 \\
.610 \\
.725 \\
.710 \\
.725 \\
.740 \\
.790 \\
.810\end{array}$ \\
\hline $\begin{array}{c}\text { B4a.* } \\
\text { b.* } \\
\text { c. } \\
\text { d. } \\
\text { e.* } \\
\text { f.* } \\
\text { g. }\end{array}$ & $\begin{array}{l}.0175 \\
.0174 \\
.0168 \\
.0168\end{array}$ & $\begin{array}{l}80.8 \\
80.8 \\
89.4 \\
90.4\end{array}$ & $\begin{array}{l}4.9 \\
4.9 \\
5.8 \\
5.7 \\
6.2 \\
6.2\end{array}$ & $\begin{array}{l}.0155 \\
.0155 \\
.0181 \\
.0180 \\
.0195 \\
.0195\end{array}$ & .464 & $\begin{array}{l}8.46 \\
8.46 \\
8.46 \\
8.46 \\
8.46 \\
8.46 \\
8.46\end{array}$ & $\begin{array}{l}.610 \\
.605 \\
.690 \\
.670 \\
.625 \\
.640\end{array}$ \\
\hline
\end{tabular}


II. PERFORMANCE DATA

\begin{tabular}{|c|c|c|c|c|c|c|c|}
\hline $\begin{array}{r}\text { Data } \\
\text { Set }\end{array}$ & $\begin{array}{l}\text { Gross } \\
\text { Force } \\
\text { (lbf) }\end{array}$ & $\begin{array}{l}\text { Net } \\
\text { Force } \\
\text { (lbf) } \\
\end{array}$ & $\begin{array}{c}\text { Torque } \\
\text { (ft-lbf) }\end{array}$ & $\begin{array}{l}\text { Speed } \\
\text { (rpm) }\end{array}$ & $\begin{array}{c}\text { Measured } \\
\text { Output } \\
\text { (hp) } \\
\end{array}$ & $\begin{array}{c}\text { Theoretica } \\
\text { Input } \\
\text { (hp) }\end{array}$ & $\begin{array}{c}\text { Efficiency } \\
(\%)\end{array}$ \\
\hline $\begin{array}{c}\text { B3a.* } \\
\text { b.* } \\
\text { c. } \\
\text { d. } \\
\text { e. } \\
\text { f. } \\
\text { g. } \\
\text { h. } \\
\text { i. } \\
\text { j. }\end{array}$ & $\begin{array}{l}.111 \\
.110 \\
.120 \\
.120 \\
.143 \\
.140 \\
.143 \\
.146 \\
.156 \\
.160\end{array}$ & $\begin{array}{l}.022 \\
.021 \\
.031 \\
.031 \\
.054 \\
.051 \\
.054 \\
.057 \\
.067 \\
.071\end{array}$ & $\begin{array}{l}.010 \\
.010 \\
.015 \\
.015 \\
.026 \\
.024 \\
.026 \\
.027 \\
.032 \\
.034\end{array}$ & $\begin{array}{l}30000 \\
30000 \\
30000 \\
30000 \\
30000 \\
30000 \\
30000 \\
30000 \\
30000 \\
30000\end{array}$ & $\begin{array}{l}.0596 \\
.0569 \\
.0840 \\
.0840 \\
.1464 \\
.1383 \\
.1464 \\
.1545 \\
.1816 \\
.1925\end{array}$ & $\begin{array}{l}.602 \\
.605 \\
.730 \\
.743 \\
.927 \\
.916 \\
1.13 \\
1.12 \\
1.31 \\
1.34\end{array}$ & $\begin{array}{r}9.9 \\
9.4 \\
11.5 \\
11.3 \\
15.8 \\
15.1 \\
13.0 \\
13.8 \\
13.9 \\
14.4\end{array}$ \\
\hline 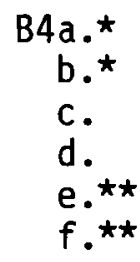 & $\begin{array}{l}.120 \\
.119 \\
.136 \\
.132 \\
.123 \\
.126\end{array}$ & $\begin{array}{l}.029 \\
.028 \\
.045 \\
.041\end{array}$ & $\begin{array}{l}.014 \\
.013 \\
.021 \\
.019\end{array}$ & $\begin{array}{l}40000 \\
40000 \\
40000 \\
40000 \\
48000 \\
45000\end{array}$ & $\begin{array}{l}.1048 \\
.1012 \\
.1627 \\
.1428\end{array}$ & $\begin{array}{l}1.09 \\
1.09 \\
1.33 \\
1.29\end{array}$ & $\begin{array}{r}9.6 \\
9.3 \\
12.2 \\
11.1\end{array}$ \\
\hline
\end{tabular}


II . PERFORMANCE DATA

\begin{tabular}{|c|c|c|c|c|c|c|c|}
\hline \multirow[b]{3}{*}{$\begin{array}{r}\text { Data } \\
\text { Set } \\
\end{array}$} & \multicolumn{2}{|c|}{ Air Temperature } & \multicolumn{5}{|c|}{ Pressure } \\
\hline & \multirow[b]{2}{*}{$\begin{array}{c}\text { Rotameter } \\
\text { Inlet } \\
\text { (OF) } \\
\end{array}$} & \multirow[b]{2}{*}{$\begin{array}{c}\text { Turbine } \\
\text { In let } \\
\left(O_{F}\right) \\
\end{array}$} & \multicolumn{4}{|c|}{ Output Voltages } & \multirow[b]{2}{*}{$\begin{array}{l}\text { Turbine } \\
\text { Inlet } \\
\text { (psia) }\end{array}$} \\
\hline & & & $\begin{array}{c}\text { Transducer } \\
\text { Excitation } \\
\text { Voltage } \\
(V D C) \\
\end{array}$ & $\begin{array}{c}\text { Rotameter } \\
\text { Inlet } \\
(v) \\
\end{array}$ & $\begin{array}{c}\text { Turbine } \\
\text { Inlet } \\
(\mathrm{V}) \\
\end{array}$ & $\begin{array}{c}\text { Rotameter } \\
\text { Inlet } \\
\text { (psia) } \\
\end{array}$ & \\
\hline \multicolumn{8}{|l|}{ Cla. } \\
\hline b. * & 74 & 74 & 12.58 & 4.05 & .281 & 115.6 & 21.4 \\
\hline c.* & 73 & 73 & 12.58 & 4.00 & .274 & 114.3 & 21.2 \\
\hline d. & 73 & 73 & 12.58 & 3.86 & .821 & 110.8 & 34.9 \\
\hline e. & 73 & 73 & 12.58 & 3.73 & .802 & 107.6 & 34.4 \\
\hline f. & 73 & 73 & 12.58 & 3.60 & 1.19 & 104.3 & 44.1 \\
\hline g. & 73 & 73 & 12.58 & 3.60 & 1.19 & 104.3 & 44.1 \\
\hline h. & 73 & 73 & 12.58 & 3.59 & 1.56 & 104.1 & 53.3 \\
\hline i. & 73 & 73 & 12.58 & 3.59 & 1.57 & 104.1 & 53.6 \\
\hline j. & 73 & 73 & 12.58 & 3.63 & 2.04 & 105.1 & 65.3 \\
\hline k. & 73 & 73 & 12.58 & 3.50 & 1.99 & 101.8 & 64.1 \\
\hline 1. & 73 & 73 & 12.58 & 3.53 & 2.41 & 102.6 & 74.6 \\
\hline m. & 73 & 73 & 12.58 & 3.69 & 2.51 & 106.6 & 77.1 \\
\hline n. & 73 & 73 & 12.58 & 3.66 & 2.90 & 105.8 & 86.8 \\
\hline 0. & 73 & 73 & 12.58 & 3.46 & 2.78 & 100.8 & 83.8 \\
\hline p. & 73 & 73 & 12.58 & 3.60 & 3.25 & 104.3 & 95.6 \\
\hline$q$. & 73 & 73 & 12.58 & 3.57 & 3.19 & 103.6 & 94.1 \\
\hline $\mathrm{C} 2 \mathrm{a} . \star *$ & 73 & 73 & 12.58 & 3.99 & .807 & 114.1 & 34.5 \\
\hline b.* & 73 & 73 & 12.58 & 3.92 & .792 & 112.3 & 34.1 \\
\hline C. & 73 & 73 & 12.58 & 3.74 & 1.18 & 107.8 & 43.8 \\
\hline d. & 73 & 73 & 12.58 & 3.76 & 1.19 & 108.3 & 44.1 \\
\hline e. & 73 & 73 & 12.58 & 3.62 & 1.60 & 104.8 & 54.3 \\
\hline f. & 73 & 73 & 12.58 & 3.67 & 1.62 & 106.1 & 54.8 \\
\hline g. & 73 & 73 & 12.58 & 3.57 & 2.01 & 103.6 & 64.6 \\
\hline h. & 73 & 73 & 12.58 & 3.60 & 2.03 & 104.3 & 65.1 \\
\hline i. & 73 & 73 & 12.58 & 3.53 & 2.39 & 102.6 & 74.1 \\
\hline j. & 73 & 73 & 12.58 & 3.57 & 2.42 & 103.6 & 74.8 \\
\hline k. & 73 & 73 & 12.58 & 3.54 & 2.82 & 102.8 & 84.8 \\
\hline 1. & 73 & 73 & 12.58 & 3.55 & 2.82 & 103.1 & 84.8 \\
\hline $\mathrm{m}$. & 73 & 73 & 12.58 & 3.66 & 3.21 & 105.8 & 94.6 \\
\hline$n$. & 73 & 73 & 12.58 & 3.45 & 3.07 & 100.6 & 91.1 \\
\hline
\end{tabular}


II. PERFORMANCE DATA

Turbine Inlet Pressure Corrected Inlet

$\begin{array}{r}\begin{array}{r}\text { Data Friction } \\ \text { Set }\end{array} \begin{array}{c}\text { Pressure } \\ \text { Factor }\end{array} \\ \hline\end{array}$

Cla.

$\begin{array}{lll}\text { b.* } & .0277 & 21.0 \\ \text { c.* } & .0277 & 20.8 \\ \text { d. } & .0224 & 33.8 \\ \text { e. } & .0224 & 33.3 \\ \text { f. } & .0209 & 42.6 \\ \text { g. } & .0209 & 42.6 \\ \text { h. } & .0196 & 51.3 \\ \text { i. } & .0197 & 51.7 \\ \text { j. } & .0186 & 62.8 \\ \text { k. } & .0186 & 61.6 \\ \text { l. } & .0180 & 71.9 \\ \text { m. } & .0179 & 74.4 \\ \text { n. } & .0174 & 83.7 \\ \text { o. } & .0174 & 80.6 \\ \text { p. } & .0169 & 92.1 \\ \text { q. } & .1069 & 90.6\end{array}$

C2a.* $.0226 \quad 33.4$

b.* $.0227 \quad 33.1$

c. $\quad .0208$

d. .0208

e. .0196

f. .0195

g. .0187

h. .0187

i. $\quad .0179$

j. $\quad .0180$

k. .0174

1. .0174

m. $\quad .0170$

n. $\quad .0170$

0 .
Flow Rate

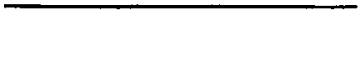

Volume Mass $\left(\mathrm{SCFM}_{0}\right)(1 \mathrm{bm} / \mathrm{sec})$

$.9 \quad .00246$

$.9 \quad .00245$

$1.9 \quad .00577$

$1.9 \quad .00569$

$2.5 \quad .00755$

$2.5 \quad .00755$

$3.2 \quad .00983$

$3.1 \quad .00950$

$3.9 \quad .0122$

$3.9 \quad .0120$

$4.4 \quad .0136$

$4.4 \quad .0139$

$5.0 \quad .0158$

$5.1 \quad .0158$

$5.6 \quad .0177$

$5.6 \quad .0176$

$1.8 \quad .00552$

$1.8 \quad .00547$

$2.5 \quad .00768$

$2.5 \quad .00770$

$3.2 \quad .00986$

$3.2 \quad .00992$

$3.8 \quad .0118$

$3.8 \quad .0118$

$4.5 \quad .0140$

$4.4 \quad .0137$

$5.0 \quad .0156$

$5.0 \quad .0156$

$5.5 \quad .0175$

$5.6 \quad .0173$
Load Cell

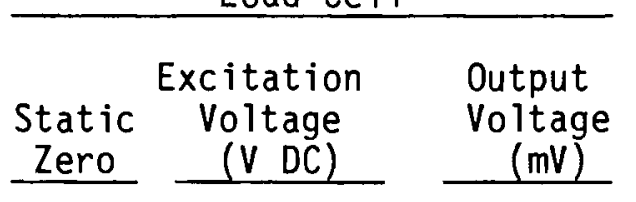

.513

8.47

8.47

8.47

8.47

8.47

8.47

8.47

8.47

8.47

8.47

8.47

8.47

8.47

8.47

8.47

8.47

8.47

.473

.475

.505

.490

.495

.495

.505

.505

.525

.520

.545

.540

.555

.565

.580

.590

8.47

8.47

8.47

8.47

8.47

8.47

8.47

8.47

8.47

8.47

8.47

8.47

8.47

8.47

8.47
.465

.465

.480

.490

.500

.490

.495

.495

.495

.495

.500

.500

.510

.505 
II. PERFORMANCE DATA

\begin{tabular}{|c|c|c|c|c|c|c|c|}
\hline $\begin{array}{r}\text { Data } \\
\text { Set }\end{array}$ & $\begin{array}{l}\text { Gross } \\
\text { Force } \\
\text { (1bf) } \\
\end{array}$ & $\begin{array}{l}\text { Net } \\
\text { Force } \\
\text { (1bf) } \\
\end{array}$ & $\begin{array}{c}\text { Torque } \\
\text { (ft-lbf) }\end{array}$ & $\begin{array}{l}\text { Speed } \\
\text { (rpm) }\end{array}$ & $\begin{array}{c}\text { Measured } \\
\text { Output } \\
\text { (hp) } \\
\end{array}$ & $\begin{array}{c}\text { Theoretical } \\
\text { Input } \\
\text { (hp) }\end{array}$ & $\begin{array}{c}\text { Efficiency } \\
(\%) \\
\end{array}$ \\
\hline $\begin{array}{c}\text { Cla. } \\
\text { b.* } \\
\text { c.* } \\
\text { d. } \\
\text { e. } \\
\text { f. } \\
\text { g. } \\
\text { h. } \\
\text { i. } \\
\text { j. } \\
\text { k. } \\
\text { l. } \\
\text { m. } \\
\text { n. } \\
\text { o. } \\
\text { p. } \\
\text { q. }\end{array}$ & $\begin{array}{l}.0931 \\
.0935 \\
.0994 \\
.0964 \\
.0974 \\
.0974 \\
.0994 \\
.0994 \\
.103 \\
.102 \\
.107 \\
.106 \\
.109 \\
.111 \\
.114 \\
.116\end{array}$ & $\begin{array}{l}.008 \\
.009 \\
.014 \\
.014 \\
.012 \\
.012 \\
.014 \\
.014 \\
.018 \\
.017 \\
.022 \\
.021 \\
.024 \\
.026 \\
.029 \\
.031\end{array}$ & $\begin{array}{l}.004 \\
.004 \\
.007 \\
.007 \\
.006 \\
.006 \\
.007 \\
.007 \\
.009 \\
.008 \\
.010 \\
.010 \\
.011 \\
.012 \\
.014 \\
.015\end{array}$ & $\begin{array}{l}10000 \\
10000 \\
10000 \\
10000 \\
10000 \\
10000 \\
10000 \\
10000 \\
10000 \\
10000 \\
10000 \\
10000 \\
10000 \\
10000 \\
10000 \\
10000\end{array}$ & $\begin{array}{l}.0073 \\
.0077 \\
.0130 \\
.0103 \\
.0112 \\
.0112 \\
.0130 \\
.0130 \\
.0163 \\
.0154 \\
.0199 \\
.0190 \\
.0190 \\
.0235 \\
.0262 \\
.0280\end{array}$ & $\begin{array}{l}.00115 \\
.00132 \\
.228 \\
.219 \\
.365 \\
.365 \\
.542 \\
.529 \\
.758 \\
.738 \\
.910 \\
.949 \\
1.12 \\
1.12 \\
1.32 \\
1.33\end{array}$ & $\begin{array}{r}15.8 \\
17.1 \\
5.7 \\
4.7 \\
3.1 \\
3.1 \\
2.4 \\
2.5 \\
2.2 \\
2.1 \\
2.2 \\
2.0 \\
1.7 \\
2.1 \\
2.0 \\
2.1\end{array}$ \\
\hline $\begin{array}{c}\text { C2a.* } \\
\text { b.* } \\
\text { c. } \\
\text { d. } \\
\text { e. } \\
\text { f. } \\
\text { g. } \\
\text { h. } \\
\dot{i} . \\
\text { j. } \\
\text { k. } \\
\text { l. } \\
\text { m. } \\
\text { n. }\end{array}$ & $\begin{array}{l}.0915 \\
.0915 \\
.0945 \\
.0964 \\
.0984 \\
.0964 \\
.0974 \\
.0974 \\
.0974 \\
.0974 \\
.0984 \\
.0984 \\
.100 \\
.099\end{array}$ & $\begin{array}{l}.007 \\
.007 \\
.010 \\
.011 \\
.013 \\
.011 \\
.012 \\
.012 \\
.012 \\
.012 \\
.013 \\
.013 \\
.015 \\
.014\end{array}$ & $\begin{array}{l}.003 \\
.003 \\
.005 \\
.005 \\
.006 \\
.005 \\
.006 \\
.006 \\
.006 \\
.006 \\
.006 \\
.006 \\
.007 \\
.007\end{array}$ & $\begin{array}{l}20000 \\
20000 \\
20000 \\
20000 \\
20000 \\
20000 \\
20000 \\
20000 \\
20000 \\
20000 \\
20000 \\
20000 \\
20000 \\
20000\end{array}$ & $\begin{array}{l}.0118 \\
.0118 \\
.0172 \\
.0206 \\
.0242 \\
.0206 \\
.0224 \\
.0224 \\
.0224 \\
.0224 \\
.0242 \\
.0242 \\
.0271 \\
.0271\end{array}$ & $\begin{array}{c}.215 \\
.210 \\
.370 \\
.375 \\
.550 \\
.558 \\
.723 \\
.735 \\
.934 \\
.915 \\
1.10 \\
1.10 \\
1.30 \\
1.29\end{array}$ & $\begin{array}{l}5.5 \\
5.6 \\
4.7 \\
5.5 \\
4.4 \\
3.7 \\
3.1 \\
3.1 \\
2.4 \\
2.5 \\
2.2 \\
2.2 \\
2.1 \\
2.1\end{array}$ \\
\hline
\end{tabular}


II. PERFORMANCE DATA

\begin{tabular}{|c|c|c|c|c|c|c|c|}
\hline \multirow[b]{2}{*}{$\begin{array}{r}\text { Data } \\
\text { Set } \\
\end{array}$} & \multicolumn{2}{|c|}{ Air Temperature } & \multicolumn{5}{|c|}{ Pressure } \\
\hline & $\begin{array}{c}\text { Rotameter } \\
\text { Inlet } \\
\left({ }^{\circ} \mathrm{F}\right) \\
\end{array}$ & $\begin{array}{c}\text { Turbine } \\
\text { Inlet } \\
\text { (OF) } \\
\end{array}$ & $\begin{array}{l}\text { Gage } \\
\text { Zero } \\
\text { (psig) }\end{array}$ & $\begin{array}{l}\text { Relative } \\
\text { Rotameter } \\
\text { Inlet } \\
\text { (psig) } \\
\end{array}$ & $\begin{array}{c}\text { ressure } \\
\text { Turbine } \\
\text { Inlet } \\
\text { (psig) }\end{array}$ & $\begin{array}{c}\text { Absolute } \\
\text { Rotameter } \\
\text { Inlet } \\
\text { (psia) } \\
\end{array}$ & $\begin{array}{c}\text { Pressure } \\
\text { Turbine } \\
\text { Inlet } \\
\text { (psia) } \\
\end{array}$ \\
\hline $\begin{array}{c}\text { Ela. } \\
\text { b.* } \\
\text { c.* } \\
\text { d. } \\
\text { e. } \\
\text { f. } \\
\text { g. } \\
\text { h. } \\
\text { i. } \\
\text { j. } \\
\text { k. } \\
\text { l. } \\
\text { m. } \\
\text { n. } \\
\text { o. }\end{array}$ & $\begin{array}{l}73 \\
73 \\
73 \\
73 \\
73 \\
73 \\
73 \\
73 \\
73 \\
73 \\
73 \\
73 \\
73 \\
73\end{array}$ & $\begin{array}{l}73 \\
73 \\
73 \\
73 \\
73 \\
73 \\
73 \\
73 \\
73 \\
73 \\
73 \\
73 \\
73 \\
73\end{array}$ & -3.6 & $\begin{array}{l}99.2 \\
97.7 \\
96.4 \\
96.5 \\
89.7 \\
88.0 \\
86.7 \\
87.8 \\
86.5 \\
86.5 \\
90.0 \\
85.1 \\
83.8 \\
88.0\end{array}$ & $\begin{array}{l}4.1 \\
4.1 \\
6.6 \\
6.7 \\
16.3 \\
15.8 \\
26.0 \\
26.5 \\
35.6 \\
35.8 \\
47.9 \\
46.8 \\
56.4 \\
56.2\end{array}$ & $\begin{array}{l}117.3 \\
115.8 \\
114.5 \\
114.6 \\
107.8 \\
106.1 \\
104.8 \\
105.9 \\
104.6 \\
104.6 \\
108.1 \\
103.2 \\
101.9 \\
106.1\end{array}$ & $\begin{array}{l}22.2 \\
22.2 \\
24.7 \\
24.8 \\
34.4 \\
33.9 \\
44.1 \\
44.6 \\
53.7 \\
53.9 \\
66.0 \\
64.9 \\
74.5 \\
74.3\end{array}$ \\
\hline
\end{tabular}


II. PERFORMANCE DATA

\begin{tabular}{|c|c|c|c|c|c|c|c|}
\hline \multirow[b]{2}{*}{$\begin{array}{r}\text { Data } \\
\text { Set } \\
\end{array}$} & \multirow{2}{*}{\multicolumn{2}{|c|}{$\begin{array}{cc}\text { Turbine Inlet Pressure } & \begin{array}{c}\text { Corrected } \\
\text { Inlet }\end{array} \\
\text { Friction } & \text { Pressure } \\
\text { Factor } & \text { (psia) } \\
\end{array}$}} & \multicolumn{2}{|c|}{ Flow Rate } & \multicolumn{3}{|c|}{ Load Cell } \\
\hline & & & $\begin{array}{l}\text { Volume } \\
\left(\text { SCFM }_{0}\right)\end{array}$ & $\begin{array}{c}\text { Mass } \\
(1 \mathrm{bm} / \mathrm{sec}) \\
\end{array}$ & $\begin{array}{c}\text { Static } \\
\text { Zero } \\
\end{array}$ & $\begin{array}{c}\text { Excitation } \\
\text { Voltage } \\
\text { (V DC) } \\
\end{array}$ & $\begin{array}{c}\text { Output } \\
\text { voltage } \\
(\mathrm{mV}) \\
\end{array}$ \\
\hline $\begin{array}{c}\text { Ela. } \\
\text { b.* } \\
\text { c.* } \\
\text { d. } \\
\text { e. } \\
\text { f. } \\
\text { g. } \\
\text { h. } \\
\text { i. } \\
\text { j. } \\
\text { k. } \\
\text { l. } \\
\text { m. } \\
\text { n. } \\
\text { o. }\end{array}$ & $\begin{array}{l}.0247 \\
.0247 \\
.0234 \\
.0234 \\
.0208 \\
.0208 \\
.0192 \\
.0192 \\
.0181 \\
.0182 \\
.0172 \\
.0173 \\
.0166 \\
.0166\end{array}$ & $\begin{array}{l}21.3 \\
21.4 \\
23.5 \\
23.6 \\
32.4 \\
31.9 \\
41.3 \\
41.8 \\
50.0 \\
50.4 \\
61.7 \\
60.7 \\
69.5 \\
69.3\end{array}$ & $\begin{array}{l}1.3 \\
1.3 \\
1.6 \\
1.6 \\
2.5 \\
2.5 \\
3.4 \\
3.4 \\
4.3 \\
4.2 \\
5.1 \\
5.1 \\
6.0 \\
5.9\end{array}$ & $\begin{array}{l}.00386 \\
.00384 \\
.00484 \\
.00484 \\
.00769 \\
.00763 \\
.01052 \\
.01058 \\
.01345 \\
.01312 \\
.01633 \\
.01596 \\
.01876 \\
.01881\end{array}$ & .610 & $\begin{array}{l}8.47 \\
8.47 \\
8.47 \\
8.47 \\
8.47 \\
8.47 \\
8.47 \\
8.47 \\
8.47 \\
8.47 \\
8.47 \\
8.47 \\
8.47 \\
8.47 \\
8.47\end{array}$ & $\begin{array}{l}.620 \\
.610 \\
.635 \\
.640 \\
.730 \\
.730 \\
.850 \\
.850 \\
.980 \\
.980 \\
1.140 \\
1.120 \\
1.230 \\
1.240\end{array}$ \\
\hline
\end{tabular}


II . PERFORMANCE DATA

\begin{tabular}{|c|c|c|c|c|c|c|c|}
\hline $\begin{array}{r}\text { Data } \\
\text { Set }\end{array}$ & $\begin{array}{l}\text { Gross } \\
\text { Force } \\
\text { (1bf) }\end{array}$ & $\begin{array}{l}\text { Net } \\
\text { Force } \\
\text { (lbf) }\end{array}$ & $\begin{array}{c}\text { Torque } \\
\text { (ft-lbf) }\end{array}$ & $\begin{array}{l}\text { Speed } \\
\text { (rpm) }\end{array}$ & $\begin{array}{l}\text { Measured } \\
\text { Output } \\
\text { (hp) } \\
\end{array}$ & $\begin{array}{c}\text { Theoretical } \\
\text { Input } \\
\text { (hp) }\end{array}$ & $\begin{array}{c}\text { Efficiency } \\
(\%) \\
\end{array}$ \\
\hline 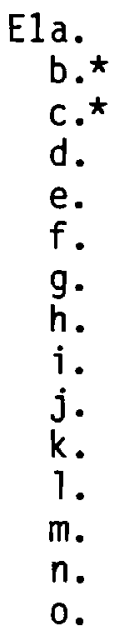 & $\begin{array}{l}.122 \\
.120 \\
.125 \\
.126 \\
.144 \\
.144 \\
.167 \\
.167 \\
.193 \\
.193 \\
.224 \\
.220 \\
.242 \\
.244\end{array}$ & $\begin{array}{l}.007 \\
.005 \\
.010 \\
.011 \\
.029 \\
.029 \\
.052 \\
.052 \\
.078 \\
.078 \\
.109 \\
.105 \\
.127 \\
.129\end{array}$ & $\begin{array}{l}.003 \\
.002 \\
.005 \\
.005 \\
.014 \\
.014 \\
.025 \\
.025 \\
.037 \\
.037 \\
.052 \\
.050 \\
.060 \\
.061\end{array}$ & $\begin{array}{l}10000 \\
10000 \\
10000 \\
10000 \\
10000 \\
10000 \\
10000 \\
10000 \\
10000 \\
10000 \\
10000 \\
10000 \\
10000 \\
10000\end{array}$ & $\begin{array}{l}.006 \\
.005 \\
.009 \\
.010 \\
.026 \\
.026 \\
.047 \\
.047 \\
.070 \\
.070 \\
.098 \\
.095 \\
.115 \\
.117\end{array}$ & $\begin{array}{l}.070 \\
.081 \\
.114 \\
.116 \\
.286 \\
.280 \\
.495 \\
.500 \\
.722 \\
.707 \\
1.00 \\
.969 \\
1.22 \\
1.23\end{array}$ & $\begin{array}{l}8.6 \\
6.2 \\
7.9 \\
8.6 \\
9.1 \\
9.3 \\
9.5 \\
9.4 \\
9.7 \\
9.9 \\
9.8 \\
9.8 \\
9.4 \\
9.5\end{array}$ \\
\hline
\end{tabular}


II. PERFORMANCE DATA

\begin{tabular}{|c|c|c|c|c|c|c|c|}
\hline \multirow[b]{2}{*}{$\begin{array}{r}\text { Data } \\
\text { Set } \\
\end{array}$} & \multicolumn{2}{|c|}{ Air Temperature } & \multicolumn{5}{|c|}{ Pressure } \\
\hline & $\begin{array}{c}\text { Rotameter } \\
\text { Inlet } \\
\left({ }^{\circ} \mathrm{F}\right) \\
\end{array}$ & $\begin{array}{c}\text { Turbine } \\
\text { Inlet } \\
\left(O^{O}\right) \\
\end{array}$ & $\begin{array}{l}\text { Gage } \\
\text { Zero } \\
\text { (psig) }\end{array}$ & $\begin{array}{c}\text { Relative } \\
\text { Rotameter } \\
\text { Inlet } \\
\text { (psig) } \\
\end{array}$ & $\begin{array}{c}\text { Pressure } \\
\text { Turbine } \\
\text { Inlet } \\
\text { (psig) } \\
\end{array}$ & $\begin{array}{c}\text { Absolute } \\
\text { Rotameter } \\
\text { Inlet } \\
\text { (psia) } \\
\end{array}$ & $\begin{array}{c}\text { Pressure } \\
\text { Turbine } \\
\text { Inlet } \\
\text { (psia) } \\
\end{array}$ \\
\hline $\begin{array}{c}\text { E2a. } \\
\text { b.* } \\
\text { c.* } \\
\text { d. } \\
\text { e. } \\
\text { f. } \\
\text { g. }\end{array}$ & $\begin{array}{l}72 \\
72 \\
72 \\
72 \\
72 \\
72\end{array}$ & $\begin{array}{l}72 \\
72 \\
72 \\
72 \\
72 \\
72\end{array}$ & -3.9 & $\begin{array}{l}97.4 \\
97.4 \\
90.7 \\
89.3 \\
88.3 \\
88.1\end{array}$ & $\begin{array}{l}11.0 \\
10.8 \\
16.3 \\
16.0 \\
26.2 \\
26.2\end{array}$ & $\begin{array}{l}115.8 \\
115.8 \\
109.1 \\
107.7 \\
106.7 \\
106.5\end{array}$ & $\begin{array}{l}29.4 \\
29.2 \\
34.7 \\
34.4 \\
44.6 \\
44.6\end{array}$ \\
\hline $\begin{array}{c}\text { E3a. } \\
\text { b. } \\
\text { c. } \\
\text { d. } \\
\text { e. } \\
\text { f. } \\
\text { g. } \\
\text { h. } \\
\text { i. } \\
\text { j. } \\
\text { k. }\end{array}$ & $\begin{array}{l}72 \\
72 \\
72 \\
72 \\
72 \\
72 \\
72 \\
73 \\
73 \\
73\end{array}$ & $\begin{array}{l}72 \\
72 \\
72 \\
72 \\
72 \\
72 \\
72 \\
73 \\
73 \\
73\end{array}$ & -3.2 & $\begin{array}{l}91.0 \\
91.0 \\
85.0 \\
88.8 \\
88.0 \\
89.7 \\
83.2 \\
85.6 \\
86.2 \\
83.0\end{array}$ & $\begin{array}{l}34.7 \\
35.2 \\
46.6 \\
46.5 \\
53.8 \\
56.0 \\
70.6 \\
66.9 \\
76.1 \\
77.0\end{array}$ & $\begin{array}{l}108.7 \\
108.7 \\
102.7 \\
106.5 \\
105.7 \\
107.4 \\
100.9 \\
103.3 \\
103.9 \\
100.7\end{array}$ & $\begin{array}{l}52.4 \\
52.9 \\
64.3 \\
64.2 \\
71.5 \\
73.7 \\
88.3 \\
84.6 \\
93.8 \\
94.7\end{array}$ \\
\hline $\begin{array}{c}\text { E4a.* } \\
\text { b.* } \\
\text { c. } \\
\text { d. } \\
\text { e. } \\
\text { f. } \\
\text { g. } \\
\text { h. } \\
\text { i. } \\
\text { j. } \\
\text { k. } \\
\text { l. }\end{array}$ & $\begin{array}{l}73 \\
73 \\
73 \\
73 \\
73 \\
73 \\
73 \\
73 \\
73 \\
73 \\
73 \\
73\end{array}$ & $\begin{array}{l}73 \\
73 \\
73 \\
73 \\
73 \\
73 \\
73 \\
73 \\
73 \\
73 \\
73 \\
73\end{array}$ & & $\begin{array}{l}91.7 \\
93.8 \\
88.9 \\
88.1 \\
87.3 \\
89.3 \\
85.0 \\
85.8 \\
84.5 \\
85.3 \\
84.2 \\
88.8\end{array}$ & $\begin{array}{l}26.6 \\
27.0 \\
37.5 \\
37.1 \\
49.0 \\
51.0 \\
58.2 \\
58.1 \\
68.8 \\
70.9 \\
78.0 \\
79.7\end{array}$ & $\begin{array}{l}109.4 \\
111.5 \\
106.6 \\
105.8 \\
105.0 \\
107.0 \\
102.7 \\
103.5 \\
102.2 \\
103.0 \\
101.9 \\
106.5\end{array}$ & $\begin{array}{l}55.2 \\
54.8 \\
66.7 \\
68.7 \\
75.9 \\
75.8 \\
86.5 \\
88.6 \\
95.7 \\
97.4\end{array}$ \\
\hline
\end{tabular}


Turbine Inlet Pressure Corrected

Data Friction Pressure Set Factor (psia) E2a.

b.* .0220

c.* .0220

d. $\quad .0210$

e. .0210

f. .0192

g. .0192

E3a.

b. .0181

c. .0181

d. $\quad .0172$

e. .0172

f. .0167

g. .0167

h. .0161

i. $\quad .0159$

j. .0156

k. .0157

E4a.* .0191

b.* .0191

c. .0181

d. .0181

e. .0171

f. .0171

g. .0166

h. .0165

i. $\quad .0160$

j. .0160

k. .0156

1. .0155 Inlet

Flow Rate

\begin{tabular}{cc}
\hline & \\
$\begin{array}{c}\text { Volume } \\
\text { (SCFM })\end{array}$ & $\begin{array}{c}\text { Mass } \\
\text { (1bm/sec }\end{array}$ \\
\hline & \\
2.0 & .0062 \\
2.0 & .0062 \\
2.5 & .0077 \\
2.5 & .0077 \\
3.4 & .0106 \\
3.4 & .0106
\end{tabular}

48.7

49.2

59.7

59.6

66.4

68.7

82.8

78.4

87.2

88.7

41.4

41.7

51.5

51.1

62.2

64.2

70.8

70.6

80.6

82.8

89.3

90.9
$4.2 \quad .0134$

$4.2 \quad .0134$

$5.3 \quad .0166$

$5.2 \quad .0165$

$5.8 \quad .0184$

$5.8 \quad .0186$

$6.9 \quad .0215$

$7.1 \quad .0224$

$\begin{array}{ll}7.7 & .0244\end{array}$

$\begin{array}{ll}7.5 & .0234\end{array}$

$\begin{array}{ll}3.4 & .0107\end{array}$

$3.4 \quad .0108$

$4.3 \quad .0136$

$4.3 \quad .0135$

$\begin{array}{ll}5.3 & .0167\end{array}$

$5.3 \quad .0169$

$6.1 \quad .0191$

$6.1 \quad .0192$

$\begin{array}{ll}7.0 & .0220\end{array}$

$\begin{array}{ll}7.0 & .0221\end{array}$

$\begin{array}{ll}7.7 & .0242\end{array}$

$\begin{array}{ll}7.7 & .0248\end{array}$
Load Cell

Excitation Outlet

Voltage Voltage

$(V \mathrm{DC}) \quad(\mathrm{mV})$

.605

8.46

8.46

8.46

8.47

8.47

8.47

8.47

.625

.625

.670

.670

.780

.775

.699

8.47

8.47

8.47

8.47

8.47

8.47

8.47

8.47

8.47

8.47

8.47

8.47

8.47

8.47

8.47

8.47

8.47

8.47

8.47

8.47

8.47

8.47

8.47
.890

.885

1.020

1.040

1.150

1.160

1.360

1.380

1.470

1.440

.760

.760

.870

.875

.995

1.01

1.07

1.07

1.18

1.19

1.25 
II. PERFORMANCE DATA

\begin{tabular}{|c|c|c|c|c|c|c|c|}
\hline \multirow[b]{2}{*}{$\begin{array}{r}\text { Data } \\
\text { Set } \\
\end{array}$} & \multirow[b]{2}{*}{$\begin{array}{l}\text { Gross } \\
\text { Force } \\
\text { (1bf) } \\
\end{array}$} & \multirow[b]{2}{*}{$\begin{array}{c}\text { Net } \\
\text { Force } \\
\text { (lbf) }\end{array}$} & \multirow[b]{2}{*}{$\begin{array}{c}\begin{array}{c}\text { Torque } \\
\text { (ft-lbf) }\end{array} \\
\end{array}$} & \multirow[b]{2}{*}{$\begin{array}{l}\text { Speed } \\
\text { (rpm) }\end{array}$} & \\
\hline & & & & & $\begin{array}{l}\text { Measured } \\
\text { Output } \\
\text { (hp) }\end{array}$ & $\begin{array}{c}\text { Theoretical } \\
\text { Input } \\
\text { (hp) }\end{array}$ & $\begin{array}{c}\text { Efficiency } \\
(\%)\end{array}$ \\
\hline $\begin{array}{l}\text { Ea. } \\
\text { b.* } \\
\text { c.* } \\
\text { d. } \\
\text { e. } \\
\text { f. } \\
\text { g. }\end{array}$ & $\begin{array}{l}.123 \\
.123 \\
.132 \\
.132 \\
.154 \\
.153\end{array}$ & $\begin{array}{l}.005 \\
.005 \\
.014 \\
.014 \\
.036 \\
.035\end{array}$ & $\begin{array}{l}.0024 \\
.0024 \\
.0066 \\
.0066 \\
.017 \\
.017\end{array}$ & $\begin{array}{l}20000 \\
20000 \\
20000 \\
20000 \\
20000 \\
20000\end{array}$ & $\begin{array}{l}.009 \\
.009 \\
.025 \\
.025 \\
.065 \\
.063\end{array}$ & $\begin{array}{l}.192 \\
.188 \\
.287 \\
.281 \\
.500 \\
.500\end{array}$ & $\begin{array}{r}4.7 \\
4.8 \\
8.7 \\
8.9 \\
13.0 \\
12.6\end{array}$ \\
\hline $\begin{array}{c}\text { E3a. } \\
\text { b. } \\
\text { c. } \\
\text { d. } \\
\text { e. } \\
\text { f. } \\
\text { g. } \\
\text { h. } \\
\text { i. } \\
\text { j. } \\
\text { k. }\end{array}$ & $\begin{array}{l}.174 \\
.174 \\
.201 \\
.205 \\
.226 \\
.228 \\
.268 \\
.272 \\
.289 \\
.283\end{array}$ & $\begin{array}{l}.057 \\
.056 \\
.083 \\
.087 \\
.108 \\
.110 \\
.150 \\
.154 \\
.171 \\
.165\end{array}$ & $\begin{array}{l}.0271 \\
.0266 \\
.0394 \\
.0413 \\
.0513 \\
.0522 \\
.0712 \\
.0731 \\
.0812 \\
.0783\end{array}$ & $\begin{array}{l}20000 \\
20000 \\
20000 \\
20000 \\
20000 \\
20000 \\
20000 \\
20000 \\
20000 \\
20000\end{array}$ & $\begin{array}{l}.103 \\
.101 \\
.150 \\
.157 \\
.195 \\
.199 \\
.271 \\
.278 \\
.309 \\
.298\end{array}$ & $\begin{array}{l}.706 \\
.711 \\
.993 \\
.994 \\
1.17 \\
1.21 \\
1.52 \\
1.55 \\
1.78 \\
1.71\end{array}$ & $\begin{array}{l}14.6 \\
14.2 \\
15.1 \\
15.8 \\
16.6 \\
16.5 \\
17.8 \\
17.9 \\
17.4 \\
17.4\end{array}$ \\
\hline $\begin{array}{c}\text { E4a.* } \\
\text { b.* } \\
\text { c. } \\
\text { d. } \\
\text { e. } \\
\text { f. } \\
\text { g. } \\
\text { h. } \\
\text { i. } \\
\text { j. } \\
\text { k. } \\
\text { l. }\end{array}$ & $\begin{array}{l}.150 \\
.150 \\
.171 \\
.172 \\
.196 \\
.199 \\
.211 \\
.211 \\
.232 \\
.234 \\
.246 \\
.252\end{array}$ & $\begin{array}{l}.022 \\
.022 \\
.043 \\
.044 \\
.068 \\
.071 \\
.083 \\
.083 \\
.104 \\
.106 \\
.118 \\
.124\end{array}$ & $\begin{array}{l}.0104 \\
.0104 \\
.0204 \\
.0209 \\
.0323 \\
.0337 \\
.0394 \\
.0394 \\
.0494 \\
.0503 \\
.0560 \\
.0589\end{array}$ & $\begin{array}{l}30000 \\
30000 \\
30000 \\
30000 \\
30000 \\
30000 \\
30000 \\
30000 \\
30000 \\
30000 \\
30000 \\
30000\end{array}$ & $\begin{array}{l}.060 \\
.060 \\
.117 \\
.119 \\
.184 \\
.193 \\
.225 \\
.225 \\
.282 \\
.287 \\
.320 \\
.336\end{array}$ & $\begin{array}{l}.509 \\
.517 \\
.750 \\
.739 \\
1.03 \\
1.06 \\
1.26 \\
1.26 \\
1.54 \\
1.57 \\
1.78 \\
1.83\end{array}$ & $\begin{array}{l}11.8 \\
11.6 \\
15.6 \\
16.1 \\
17.9 \\
18.2 \\
17.8 \\
17.8 \\
18.3 \\
18.3 \\
18.0 \\
18.4\end{array}$ \\
\hline
\end{tabular}


II. PERFORMANCE DATA

\begin{tabular}{|c|c|c|c|c|c|c|c|}
\hline \multirow[b]{2}{*}{$\begin{array}{c}\text { Data } \\
\text { Set }\end{array}$} & \multicolumn{2}{|c|}{ Air Temperature } & \multicolumn{5}{|c|}{ Pressure } \\
\hline & $\begin{array}{c}\text { Rotameter } \\
\text { Inlet } \\
\text { (OF) }\end{array}$ & $\begin{array}{c}\text { Turbine } \\
\text { Inlet } \\
\left(\mathrm{OF}^{\circ}\right)\end{array}$ & $\begin{array}{l}\text { Gage } \\
\text { Zero } \\
\text { (psig) }\end{array}$ & $\begin{array}{l}\text { Relative } \\
\text { Rotameter } \\
\text { Inlet } \\
\text { (psig) }\end{array}$ & $\begin{array}{c}\text { Pressure } \\
\text { Turbine } \\
\text { Inlet } \\
\text { (psig) }\end{array}$ & $\begin{array}{c}\text { Absolute } \\
\text { Rotameter } \\
\text { Inlet } \\
\text { (psia) }\end{array}$ & $\begin{array}{l}\text { Pressure } \\
\text { Turbine } \\
\text { Inlet } \\
\text { (psia) }\end{array}$ \\
\hline $\begin{array}{c}\text { E5a.* } \\
\text { b.* } \\
\text { c. } \\
\text { d. } \\
\text { e. } \\
\text { f. } \\
\text { g. } \\
\text { h. }\end{array}$ & $\begin{array}{l}73 \\
73 \\
73 \\
73 \\
74 \\
74 \\
74 \\
74\end{array}$ & $\begin{array}{l}73 \\
73 \\
73 \\
73 \\
74 \\
74 \\
74 \\
74\end{array}$ & & $\begin{array}{l}89.6 \\
88.2 \\
86.7 \\
86.8 \\
85.8 \\
87.2 \\
90.1 \\
85.0\end{array}$ & $\begin{array}{l}50.4 \\
50.7 \\
54.8 \\
54.9 \\
68.6 \\
70.4 \\
80.4 \\
78.7\end{array}$ & $\begin{array}{l}107.3 \\
105.9 \\
104.4 \\
104.5 \\
103.5 \\
104.9 \\
107.8 \\
102.7\end{array}$ & $\begin{array}{l}68.1 \\
68.4 \\
72.5 \\
72.6 \\
86.3 \\
88.1 \\
98.1 \\
96.4\end{array}$ \\
\hline
\end{tabular}

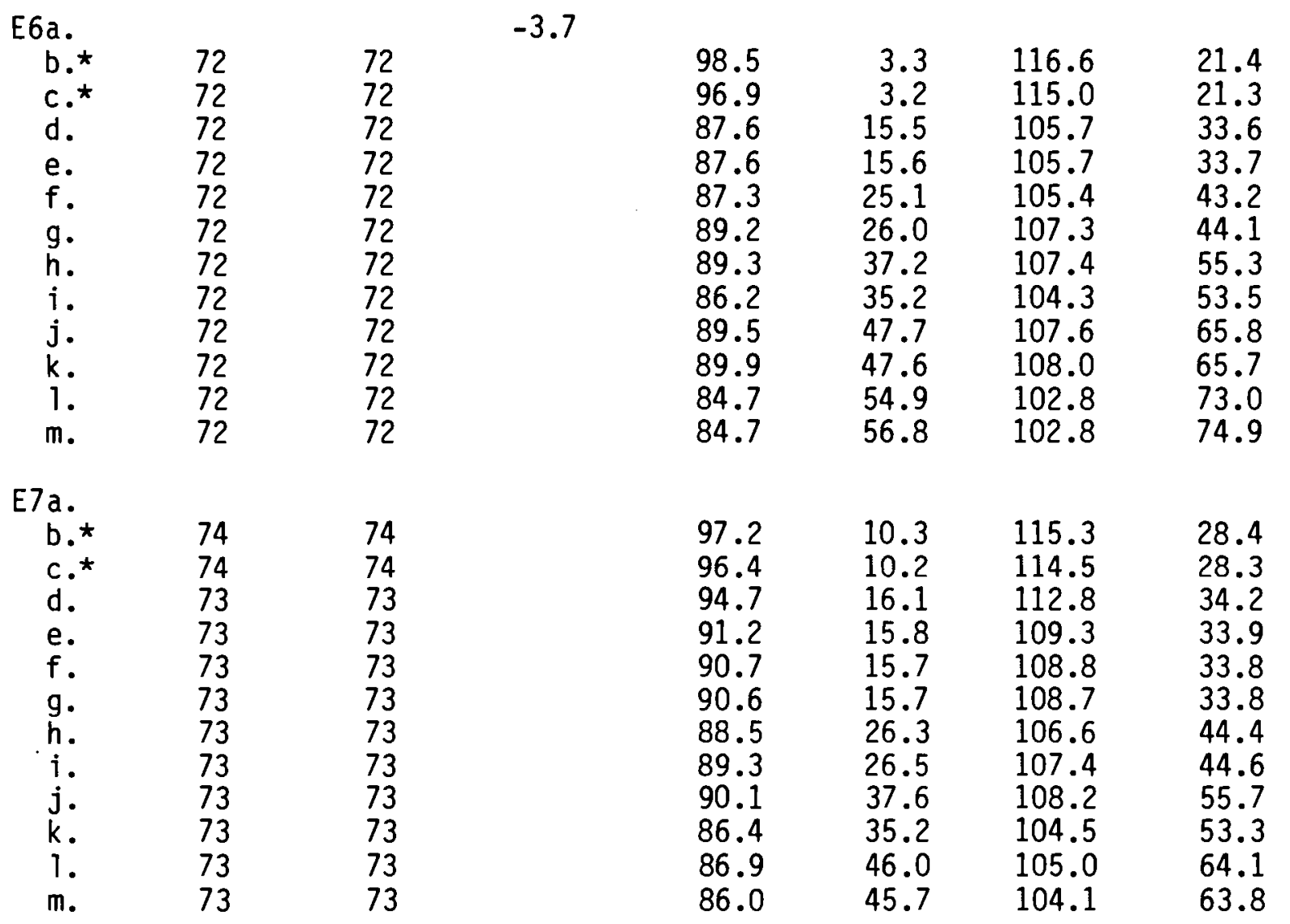


II. PERFORMANCE DATA

\begin{tabular}{|c|c|c|c|c|c|c|c|}
\hline \multirow[b]{2}{*}{$\begin{array}{r}\text { Data } \\
\text { Set } \\
\end{array}$} & \multicolumn{2}{|c|}{ Turbine Inlet Pressure } & \multicolumn{2}{|c|}{ Flow Rate } & \multicolumn{3}{|c|}{ Load Cell } \\
\hline & $\begin{array}{c}\text { Friction } \\
\text { Factor } \\
\end{array}$ & $\begin{array}{l}\text { Inlet } \\
\text { Pressure } \\
\text { (psia) }\end{array}$ & $\begin{array}{l}\text { Volume } \\
(\text { SCFM })\end{array}$ & $\begin{array}{c}\text { Mass } \\
(1 \mathrm{bm} / \mathrm{sec})\end{array}$ & $\begin{array}{c}\text { Static } \\
\text { Zero } \\
\end{array}$ & $\begin{array}{c}\text { Excitation } \\
\text { Voltage } \\
(V D C) \\
\end{array}$ & $\begin{array}{r}\text { Output } \\
\text { voltage } \\
(\mathrm{mV}) \\
\end{array}$ \\
\hline $\begin{array}{c}\text { E5a.* } \\
\text { b.* } \\
\text { c. } \\
\text { d. } \\
\text { e. } \\
\text { f. } \\
\text { g. } \\
\text { h. } \\
\text { i. }\end{array}$ & $\begin{array}{l}.0170 \\
.0170 \\
.0167 \\
.0167 \\
.0160 \\
.0160 \\
.0155 \\
.0156\end{array}$ & $\begin{array}{l}63.4 \\
63.8 \\
67.6 \\
67.7 \\
80.5 \\
82.4 \\
91.4 \\
89.9\end{array}$ & $\begin{array}{l}5.4 \\
5.4 \\
5.8 \\
5.8 \\
6.9 \\
6.9 \\
7.8 \\
7.8\end{array}$ & $\begin{array}{l}.0172 \\
.0171 \\
.0183 \\
.0183 \\
.0218 \\
.0219 \\
.0252 \\
.0246\end{array}$ & .564 & $\begin{array}{l}8.47 \\
8.47 \\
8.47 \\
8.47 \\
8.47 \\
8.47 \\
8.47 \\
8.47 \\
8.47\end{array}$ & $\begin{array}{l}.905 \\
.910 \\
.955 \\
.960 \\
1.08 \\
1.10 \\
1.21 \\
1.19\end{array}$ \\
\hline $\begin{array}{c}\text { E6a. } \\
\text { b.* } \\
\text { c.* } \\
\text { d. } \\
\text { e. } \\
\text { f. } \\
\text { g. } \\
\text { h. } \\
\text { i. } \\
\text { j. } \\
\text { k. } \\
\text { l. } \\
\text { m. }\end{array}$ & $\begin{array}{l}.025 \\
.025 \\
.021 \\
.021 \\
.019 \\
.019 \\
.018 \\
.018 \\
.017 \\
.017 \\
.017 \\
.017\end{array}$ & $\begin{array}{l}20.6 \\
20.5 \\
31.7 \\
31.8 \\
40.4 \\
41.3 \\
51.9 \\
49.8 \\
61.4 \\
61.2 \\
67.9 \\
69.9\end{array}$ & $\begin{array}{l}1.3 \\
1.3 \\
2.5 \\
2.5 \\
3.4 \\
3.4 \\
4.2 \\
4.2 \\
5.2 \\
5.2 \\
6.0 \\
6.0\end{array}$ & $\begin{array}{l}.0039 \\
.0038 \\
.0076 \\
.0076 \\
.0106 \\
.0106 \\
.0133 \\
.0131 \\
.0166 \\
.0167 \\
.0188 \\
.0188\end{array}$ & .558 & $\begin{array}{l}8.46 \\
8.46 \\
8.47 \\
8.47 \\
8.47 \\
8.47 \\
8.47 \\
8.47 \\
8.47 \\
8.47 \\
8.47 \\
8.47 \\
8.47\end{array}$ & $\begin{array}{r}.565 \\
.565 \\
.690 \\
.690 \\
.810 \\
.820 \\
.960 \\
.950 \\
1.12 \\
1.12 \\
1.22 \\
1.23\end{array}$ \\
\hline $\begin{array}{c}\text { E7a. } \\
\text { b.* } \\
\text { c.* } \\
\text { d. } \\
\text { e. } \\
\text { f. } \\
\text { g. } \\
\text { h. } \\
\text { i. } \\
\text { j. } \\
\text { k. } \\
\text { l. } \\
\text { m. }\end{array}$ & $\begin{array}{l}.0223 \\
.0223 \\
.021 \\
.021 \\
.021 \\
.021 \\
.0192 \\
.0192 \\
.0181 \\
.0182 \\
.0174 \\
.0174\end{array}$ & $\begin{array}{l}27.0 \\
26.9 \\
32.3 \\
32.1 \\
32.0 \\
32.0 \\
41.6 \\
41.8 \\
52.3 \\
49.8 \\
60.0 \\
59.7\end{array}$ & $\begin{array}{l}1.9 \\
1.9 \\
2.4 \\
2.4 \\
2.4 \\
2.4 \\
3.4 \\
3.4 \\
4.2 \\
4.2 \\
5.0 \\
5.0\end{array}$ & $\begin{array}{l}.006 \\
.006 \\
.0075 \\
.0074 \\
.0074 \\
.0074 \\
.0106 \\
.0106 \\
.0133 \\
.0131 \\
.0158 \\
.0157\end{array}$ & .627 & $\begin{array}{l}8.45 \\
8.45 \\
8.45 \\
8.45 \\
8.45 \\
8.45 \\
8.45 \\
8.45 \\
8.45 \\
8.45 \\
8.45 \\
8.45 \\
8.45\end{array}$ & $\begin{array}{l}.625 \\
.630 \\
.685 \\
.680 \\
.680 \\
.670 \\
.775 \\
.790 \\
.920 \\
.910 \\
1.02 \\
1.01\end{array}$ \\
\hline
\end{tabular}




\begin{tabular}{|c|c|c|c|c|c|c|c|}
\hline $\begin{array}{r}\text { Data } \\
\text { Set }\end{array}$ & $\begin{array}{l}\text { Gross } \\
\text { Force } \\
\text { (lbf) } \\
\end{array}$ & $\begin{array}{l}\text { Net } \\
\text { Force } \\
\text { (1bf) } \\
\end{array}$ & $\begin{array}{c}\text { Torque } \\
\text { (ft-1bf) }\end{array}$ & $\begin{array}{l}\text { Speed } \\
\text { (rpm) }\end{array}$ & $\begin{array}{l}\text { Peasured } \\
\text { Power } \\
\text { Output } \\
\text { (hp) }\end{array}$ & $\begin{array}{c}\text { Theoretical } \\
\text { Input } \\
\text { (hp) }\end{array}$ & $\begin{array}{c}\text { Efficiency } \\
(\%)\end{array}$ \\
\hline $\begin{array}{c}\text { E5a.* } \\
\text { b.* } \\
\text { c. } \\
\text { d. } \\
\text { e. } \\
\text { f. } \\
\text { g. } \\
\text { h. }\end{array}$ & $\begin{array}{l}.178 \\
.180 \\
.188 \\
.189 \\
.213 \\
.217 \\
.238 \\
.234\end{array}$ & $\begin{array}{l}.054 \\
.055 \\
.064 \\
.065 \\
.089 \\
.093 \\
.114 \\
.110\end{array}$ & $\begin{array}{l}.026 \\
.026 \\
.030 \\
.031 \\
.042 \\
.044 \\
.054 \\
.052\end{array}$ & $\begin{array}{l}40000 \\
40000 \\
40000 \\
40000 \\
40000 \\
40000 \\
40000 \\
40000\end{array}$ & $\begin{array}{l}.195 \\
.199 \\
.231 \\
.235 \\
.322 \\
.336 \\
.412 \\
.398\end{array}$ & $\begin{array}{l}1.07 \\
1.07 \\
1.18 \\
1.18 \\
1.53 \\
1.56 \\
1.88 \\
1.82\end{array}$ & $\begin{array}{l}18.2 \\
18.6 \\
19.6 \\
19.9 \\
21.0 \\
21.6 \\
22.0 \\
21.9\end{array}$ \\
\hline 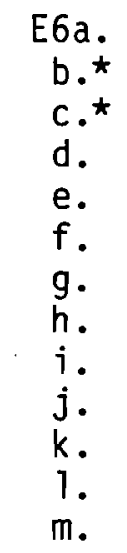 & $\begin{array}{l}.111 \\
.111 \\
.136 \\
.136 \\
.160 \\
.161 \\
.189 \\
.187 \\
.220 \\
.220 \\
.240 \\
.242\end{array}$ & $\begin{array}{r}-.004 \\
-.005 \\
.021 \\
.021 \\
.045 \\
.046 \\
.074 \\
.072 \\
.105 \\
.105 \\
.125 \\
.127\end{array}$ & $\begin{array}{r}-.002 \\
-.002 \\
.010 \\
.010 \\
.021 \\
.022 \\
.035 \\
.034 \\
.050 \\
.050 \\
.059 \\
.060\end{array}$ & $\begin{array}{l}10000 \\
10000 \\
10000 \\
10000 \\
10000 \\
10000 \\
10000 \\
10000 \\
10000 \\
10000 \\
10000 \\
10000\end{array}$ & $\begin{array}{l}-.004 \\
-.004 \\
.019 \\
.019 \\
.041 \\
.042 \\
.067 \\
.065 \\
.095 \\
.095 \\
.113 \\
.115\end{array}$ & $\begin{array}{l}.0741 \\
.0727 \\
.275 \\
.275 \\
.488 \\
.506 \\
.736 \\
.707 \\
1.02 \\
1.02 \\
1.22 \\
1.24\end{array}$ & $\begin{array}{r}-5.4 \\
-5.5 \\
6.9 \\
6.9 \\
8.4 \\
8.3 \\
9.1 \\
9.2 \\
9.3 \\
9.3 \\
9.3 \\
9.3\end{array}$ \\
\hline $\begin{array}{c}\text { E7a. } \\
\text { b.* } \\
\text { c.* } \\
\text { d. } \\
\text { e. } \\
\text { f. } \\
\text { g. } \\
\text { h. } \\
i . \\
\text { j. } \\
\text { k. } \\
\text { 1. } \\
\text { m. }\end{array}$ & $\begin{array}{l}.123 \\
.124 \\
.135 \\
.134 \\
.134 \\
.132 \\
.153 \\
.156 \\
.182 \\
.180 \\
.201 \\
.199\end{array}$ & $\begin{array}{l}.005 \\
.006 \\
.017 \\
.016 \\
.016 \\
.014 \\
.035 \\
.038 \\
.064 \\
.062 \\
.083 \\
.081\end{array}$ & $\begin{array}{l}.002 \\
.003 \\
.008 \\
.008 \\
.008 \\
.007 \\
.017 \\
.018 \\
.030 \\
.029 \\
.039 \\
.038\end{array}$ & $\begin{array}{l}20000 \\
20000 \\
20000 \\
20000 \\
20000 \\
20000 \\
20000 \\
20000 \\
20000 \\
20000 \\
20000 \\
20000\end{array}$ & $\begin{array}{l}.009 \\
.011 \\
.031 \\
.029 \\
.029 \\
.025 \\
.063 \\
.069 \\
.116 \\
.112 \\
.150 \\
.146\end{array}$ & $\begin{array}{l}.173 \\
.175 \\
.282 \\
.274 \\
.271 \\
.269 \\
.500 \\
.507 \\
.744 \\
.704 \\
.955 \\
.942\end{array}$ & $\begin{array}{r}5.2 \\
6.3 \\
11.0 \\
10.6 \\
10.7 \\
9.3 \\
12.6 \\
13.6 \\
15.6 \\
15.9 \\
15.7 \\
15.5\end{array}$ \\
\hline
\end{tabular}


34

II . PERFORMANCE DATA

\begin{tabular}{|c|c|c|c|c|c|c|c|}
\hline \multirow[b]{2}{*}{$\begin{array}{r}\text { Data } \\
\text { Set } \\
\end{array}$} & \multicolumn{2}{|c|}{ Air Temperature } & \multicolumn{5}{|c|}{ Pressure } \\
\hline & $\begin{array}{c}\text { Rotameter } \\
\text { Inlet } \\
\left({ }^{\mathrm{O}} \mathrm{F}\right) \\
\end{array}$ & $\begin{array}{c}\text { Turbine } \\
\text { Inlet } \\
\left(\mathrm{O}^{\mathrm{F}}\right) \\
\end{array}$ & $\begin{array}{c}\text { Gage } \\
\text { Zero } \\
\text { (psig) }\end{array}$ & $\begin{array}{c}\text { Relative } \\
\text { Rotameter } \\
\text { Inlet } \\
\text { (psig) } \\
\end{array}$ & $\begin{array}{c}\text { Pressure } \\
\text { Turbine } \\
\text { Inlet } \\
\text { (psig) } \\
\end{array}$ & $\begin{array}{c}\text { Absolute } P \\
\text { Rotameter } \\
\text { Inlet } \\
\text { (psia) } \\
\end{array}$ & $\begin{array}{c}\text { ressure } \\
\text { Turbine } \\
\text { Inlet } \\
\text { (psia) } \\
\end{array}$ \\
\hline $\begin{array}{c}\text { E7n. } \\
\text { o. } \\
\text { p. } \\
\text { q. } \\
\text { r. } \\
\text { s. } \\
\text { t. } \\
\text { u. } \\
\text { v. }\end{array}$ & $\begin{array}{l}73 \\
73 \\
73 \\
73 \\
73 \\
73 \\
73 \\
73\end{array}$ & $\begin{array}{l}73 \\
73 \\
73 \\
73 \\
73 \\
73 \\
73 \\
73\end{array}$ & & $\begin{array}{l}85.6 \\
88.3 \\
88.0 \\
88.5 \\
87.0 \\
87.5 \\
82.7 \\
81.0\end{array}$ & $\begin{array}{l}55.6 \\
58.7 \\
68.0 \\
67.1 \\
77.0 \\
76.9 \\
81.0 \\
80.6\end{array}$ & $\begin{array}{r}103.7 \\
106.4 \\
106.1 \\
106.6 \\
105.1 \\
105.6 \\
100.8 \\
99.1\end{array}$ & $\begin{array}{l}73.7 \\
76.8 \\
86.1 \\
85.2 \\
95.1 \\
95.0 \\
99.1 \\
98.7\end{array}$ \\
\hline $\begin{array}{c}\text { E8a.* } \\
\text { b.* } \\
\text { c. } \\
\text { d. } \\
\text { e. } \\
\text { f. } \\
\text { g. } \\
\text { h. } \\
\text { i. } \\
\text { j. } \\
\text { k. } \\
\text { l. } \\
\text { m. } \\
\text { n. }\end{array}$ & $\begin{array}{l}73 \\
72 \\
72 \\
72 \\
72 \\
72 \\
72 \\
72 \\
72 \\
72 \\
73 \\
73 \\
73 \\
73\end{array}$ & $\begin{array}{l}72 \\
72 \\
72 \\
72 \\
72 \\
72 \\
72 \\
72 \\
72 \\
72 \\
73 \\
73 \\
73 \\
73\end{array}$ & & $\begin{array}{l}92.6 \\
91.4 \\
87.5 \\
91.8 \\
78.4 \\
86.6 \\
86.2 \\
87.1 \\
84.9 \\
89.7 \\
88.0 \\
83.1 \\
87.6 \\
83.3\end{array}$ & $\begin{array}{l}31.8 \\
31.2 \\
34.5 \\
36.8 \\
45.0 \\
48.2 \\
57.0 \\
57.3 \\
65.8 \\
68.8 \\
78.3 \\
76.3 \\
84.5 \\
82.7\end{array}$ & $\begin{array}{r}110.7 \\
109.5 \\
105.6 \\
109.9 \\
96.5 \\
104.7 \\
104.3 \\
105.2 \\
103.0 \\
107.8 \\
106.1 \\
101.2 \\
105.7 \\
101.4\end{array}$ & $\begin{array}{r}49.9 \\
49.3 \\
52.6 \\
54.9 \\
63.1 \\
66.3 \\
75.1 \\
75.4 \\
83.9 \\
86.9 \\
96.4 \\
94.4 \\
102.6 \\
100.8\end{array}$ \\
\hline $\begin{array}{c}\text { E9a.* } \\
\text { b.* } \\
\text { c. } \\
\text { d. } \\
\text { e. } \\
\text { f. } \\
\text { g. } \\
\text { h. } \\
\text { i. } \\
\text { j. }\end{array}$ & $\begin{array}{l}73 \\
73 \\
73 \\
73 \\
73 \\
73 \\
73 \\
73 \\
73 \\
73\end{array}$ & $\begin{array}{l}73 \\
73 \\
73 \\
73 \\
73 \\
73 \\
73 \\
73 \\
73 \\
73\end{array}$ & & $\begin{array}{l}89.7 \\
89.4 \\
86.5 \\
87.8 \\
86.5 \\
85.8 \\
85.5 \\
90.5 \\
87.1 \\
84.4\end{array}$ & $\begin{array}{l}50.2 \\
50.6 \\
55.5 \\
55.7 \\
67.2 \\
66.2 \\
75.4 \\
77.2 \\
86.8 \\
83.6\end{array}$ & $\begin{array}{l}107.8 \\
107.5 \\
104.6 \\
105.9 \\
104.6 \\
103.9 \\
103.6 \\
108.6 \\
105.2 \\
102.5\end{array}$ & $\begin{array}{r}68.3 \\
68.7 \\
73.6 \\
73.8 \\
85.3 \\
84.3 \\
93.5 \\
95.3 \\
104.8 \\
101.7\end{array}$ \\
\hline
\end{tabular}


II. PERFORMANCE DATA

\begin{tabular}{|c|c|c|c|c|c|c|c|}
\hline \multirow[b]{2}{*}{$\begin{array}{r}\text { Data } \\
\text { Set } \\
\end{array}$} & \multirow{2}{*}{\multicolumn{2}{|c|}{$\begin{array}{lc}\text { Turbine } & \text { Inlet Pressure } \\
& \text { Corrected } \\
\text { Pressure } & \text { Inlet } \\
\text { Friction } & \text { Pressure } \\
\text { Factor } & \text { (psia) } \\
\end{array}$}} & \multicolumn{2}{|c|}{ F low Rate } & \multicolumn{3}{|c|}{ Load Cell } \\
\hline & & & $\begin{array}{l}\text { Volume } \\
\text { (SCFM }\end{array}$ & $\begin{array}{c}\text { Mass } \\
(1 \mathrm{bm} / \mathrm{sec})\end{array}$ & $\begin{array}{c}\text { Static } \\
\text { Zero } \\
\end{array}$ & $\begin{array}{c}\text { Excitation } \\
\text { Voltage } \\
\text { (V DC) }\end{array}$ & $\begin{array}{c}\text { Output } \\
\text { Voltage } \\
(\mathrm{mV})\end{array}$ \\
\hline $\begin{array}{c}\text { E7n. } \\
\text { o. } \\
\text { p. } \\
\text { q. } \\
\text { r. } \\
\text { s. } \\
\text { t. } \\
\text { u. } \\
\text { v. }\end{array}$ & $\begin{array}{l}.0167 \\
.0167 \\
.0161 \\
.0161 \\
.0157 \\
.0156 \\
.0154 \\
.0155\end{array}$ & $\begin{array}{l}68.8 \\
72.1 \\
80.6 \\
79.6 \\
88.9 \\
88.6 \\
92.3 \\
92.1\end{array}$ & $\begin{array}{l}5.9 \\
5.8 \\
6.7 \\
6.7 \\
7.5 \\
7.6 \\
8.2 \\
8.1\end{array}$ & $\begin{array}{l}.0186 \\
.0185 \\
.0214 \\
.0215 \\
.0239 \\
.0243 \\
.0257 \\
.0252\end{array}$ & 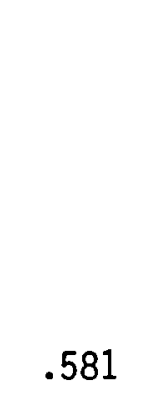 & $\begin{array}{l}8.45 \\
8.45 \\
8.45 \\
8.45 \\
8.45 \\
8.45 \\
8.45 \\
8.45 \\
8.45\end{array}$ & $\begin{array}{l}1.19 \\
1.18 \\
1.32 \\
1.34 \\
1.49 \\
1.48 \\
1.52 \\
1.53\end{array}$ \\
\hline $\begin{array}{c}\text { E8a.* } \\
\text { b.* } \\
\text { c. } \\
\text { d. } \\
\text { e. } \\
\text { f. } \\
\text { g. } \\
\text { h. } \\
\text { i. } \\
\text { j. } \\
\text { k. } \\
\text { l. } \\
\text { m. } \\
\text { n. }\end{array}$ & $\begin{array}{l}.0185 \\
.0186 \\
.0183 \\
.0181 \\
.0174 \\
.0170 \\
.0167 \\
.0167 \\
.0160 \\
.0160 \\
.0156 \\
.0157 \\
.0152 \\
.0154\end{array}$ & $\begin{array}{l}46.7 \\
46.1 \\
49.2 \\
51.4 \\
58.9 \\
61.7 \\
70.3 \\
70.7 \\
78.1 \\
81.2 \\
90.2 \\
88.2 \\
95.6 \\
94.1\end{array}$ & $\begin{array}{l}3.8 \\
3.8 \\
4.1 \\
4.2 \\
5.2 \\
5.4 \\
5.9 \\
5.8 \\
6.9 \\
6.8 \\
7.5 \\
7.6 \\
8.3 \\
8.2\end{array}$ & $\begin{array}{l}.0122 \\
.0121 \\
.0129 \\
.0135 \\
.0157 \\
.0171 \\
.0187 \\
.0184 \\
.0218 \\
.0220 \\
.0241 \\
.0238 \\
.0266 \\
.0258\end{array}$ & & $\begin{array}{l}8.46 \\
8.46 \\
8.46 \\
8.46 \\
8.46 \\
8.46 \\
8.46 \\
8.46 \\
8.46 \\
8.46 \\
8.46 \\
8.46 \\
8.46 \\
8.46\end{array}$ & $\begin{array}{l}.785 \\
.780 \\
.820 \\
.840 \\
.940 \\
.960 \\
1.06 \\
1.06 \\
1.15 \\
1.18 \\
1.28 \\
1.27 \\
1.35 \\
1.32\end{array}$ \\
\hline $\begin{array}{c}9 a . \star \\
\text { b.* } \\
\text { c. } \\
\text { d. } \\
\text { e. } \\
\text { f. } \\
\text { g. } \\
\text { h. } \\
\text { i. } \\
\text { j. }\end{array}$ & $\begin{array}{l}.0171 \\
.0171 \\
.0167 \\
.0167 \\
.0161 \\
.0161 \\
.0157 \\
.0156 \\
.0153 \\
.0153\end{array}$ & $\begin{array}{l}63.9 \\
64.3 \\
68.6 \\
69.0 \\
79.6 \\
78.6 \\
87.3 \\
88.9 \\
98.1 \\
94.8\end{array}$ & $\begin{array}{l}5.3 \\
5.3 \\
5.9 \\
5.8 \\
6.8 \\
6.8 \\
7.5 \\
7.5 \\
8.2 \\
8.3\end{array}$ & $\begin{array}{l}.0170 \\
.0169 \\
.0187 \\
.0185 \\
.0216 \\
.0215 \\
.0238 \\
.0243 \\
.0262 \\
.0262\end{array}$ & & $\begin{array}{l}8.46 \\
8.46 \\
8.46 \\
8.46 \\
8.46 \\
8.46 \\
8.46 \\
8.46 \\
8.46 \\
8.46\end{array}$ & $\begin{array}{l}.910 \\
.910 \\
.960 \\
.970 \\
1.07 \\
1.07 \\
1.15 \\
1.16 \\
1.26 \\
1.24\end{array}$ \\
\hline
\end{tabular}


II. PERFORMANCE DATA

\begin{tabular}{|c|c|c|c|c|c|c|c|}
\hline \multirow[b]{2}{*}{$\begin{array}{l}\text { Data } \\
\text { Set } \\
\end{array}$} & \multirow[b]{2}{*}{$\begin{array}{l}\text { Gross } \\
\text { Force } \\
\text { (lbf) }\end{array}$} & \multirow[b]{2}{*}{$\begin{array}{c}\text { Net } \\
\text { Force } \\
\text { (1bf) }\end{array}$} & \multirow[b]{2}{*}{$\begin{array}{c}\text { Torque } \\
\text { (ft-lbf) }\end{array}$} & \multirow[b]{2}{*}{$\begin{array}{l}\text { Speed } \\
\text { (rpm) }\end{array}$} & \multicolumn{3}{|c|}{ Turoine Pertormance } \\
\hline & & & & & $\begin{array}{c}\text { Power } \\
\text { Output } \\
\text { (hp) }\end{array}$ & $\begin{array}{r}\text { Input } \\
\text { (hp) }\end{array}$ & $\begin{array}{c}\text { Efficiency } \\
(\boldsymbol{\phi})\end{array}$ \\
\hline $\begin{array}{c}\text { E7n. } \\
\text { o. } \\
\text { p. } \\
\text { q. } \\
\text { r. } \\
\text { s. } \\
\text { t. } \\
\text { u. } \\
\text { v. }\end{array}$ & $\begin{array}{l}.235 \\
.233 \\
.260 \\
.264 \\
.294 \\
.292 \\
.300 \\
.302\end{array}$ & $\begin{array}{l}.117 \\
.115 \\
.142 \\
.146 \\
.176 \\
.174 \\
.182 \\
.184\end{array}$ & $\begin{array}{l}.056 \\
.055 \\
.067 \\
.069 \\
.084 \\
.083 \\
.086 \\
.087\end{array}$ & $\begin{array}{l}20000 \\
20000 \\
20000 \\
20000 \\
20000 \\
20000 \\
20000 \\
20000\end{array}$ & $\begin{array}{l}.211 \\
.208 \\
.257 \\
.264 \\
.318 \\
.315 \\
.329 \\
.333\end{array}$ & $\begin{array}{l}1.21 \\
1.23 \\
1.50 \\
1.50 \\
1.76 \\
1.78 \\
1.91 \\
1.87\end{array}$ & $\begin{array}{l}17.5 \\
16.9 \\
17.1 \\
17.6 \\
18.1 \\
17.7 \\
17.2 \\
17.8\end{array}$ \\
\hline $\begin{array}{c}\text { F8a.* } \\
\text { b.* } \\
\text { c. } \\
\text { d. } \\
\text { e. } \\
\text { f. } \\
\text { g. } \\
\text { h. } \\
\text { i. } \\
\text { j. } \\
\text { k. } \\
\text { l. } \\
\text { m. } \\
\text { n. }\end{array}$ & $\begin{array}{l}.155 \\
.154 \\
.162 \\
.166 \\
.185 \\
.189 \\
.209 \\
.209 \\
.227 \\
.233 \\
.252 \\
.250 \\
.266 \\
.260\end{array}$ & $\begin{array}{l}.027 \\
.026 \\
.034 \\
.038 \\
.057 \\
.061 \\
.081 \\
.081 \\
.099 \\
.105 \\
.124 \\
.122 \\
.138 \\
.132\end{array}$ & $\begin{array}{l}.013 \\
.012 \\
.016 \\
.018 \\
.027 \\
.029 \\
.038 \\
.038 \\
.047 \\
.050 \\
.059 \\
.058 \\
.065 \\
.063\end{array}$ & $\begin{array}{l}30000 \\
30000 \\
30000 \\
30000 \\
30000 \\
30000 \\
30000 \\
30000 \\
30000 \\
30000 \\
30000 \\
30000 \\
30000 \\
30000\end{array}$ & $\begin{array}{l}.073 \\
.071 \\
.092 \\
.103 \\
.155 \\
.165 \\
.220 \\
.220 \\
.268 \\
.285 \\
.336 \\
.331 \\
.374 \\
.358\end{array}$ & $\begin{array}{l}.624 \\
.623 \\
.687 \\
.741 \\
.945 \\
1.04 \\
1.23 \\
1.22 \\
1.51 \\
1.55 \\
1.78 \\
1.74 \\
2.01 \\
1.94\end{array}$ & $\begin{array}{l}11.7 \\
11.4 \\
13.4 \\
13.9 \\
16.4 \\
15.8 \\
17.9 \\
18.1 \\
17.8 \\
18.4 \\
18.9 \\
19.0 \\
18.6 \\
18.5\end{array}$ \\
\hline $\begin{array}{c}\text { E9a.* } \\
\text { b.* } \\
\text { c. } \\
\text { d. } \\
\text { e. } \\
\text { f. } \\
\text { g. } \\
\text { h. } \\
\text { i. } \\
\text { j. }\end{array}$ & $\begin{array}{l}.179 \\
.179 \\
.189 \\
.191 \\
.211 \\
.211 \\
.227 \\
.229 \\
.248 \\
.244\end{array}$ & $\begin{array}{l}.055 \\
.055 \\
.065 \\
.067 \\
.087 \\
.087 \\
.103 \\
.105 \\
.124 \\
.120\end{array}$ & $\begin{array}{l}.026 \\
.026 \\
.031 \\
.032 \\
.041 \\
.041 \\
.049 \\
.050 \\
.059 \\
.057\end{array}$ & $\begin{array}{l}40000 \\
40000 \\
40000 \\
40000 \\
40000 \\
40000 \\
40000 \\
40000 \\
40000 \\
40000\end{array}$ & $\begin{array}{r}.200 \\
.200 \\
.235 \\
.242 \\
.315 \\
.315 \\
.372 \\
.380 \\
.448 \\
.434\end{array}$ & $\begin{array}{l}1.07 \\
1.07 \\
1.21 \\
1.20 \\
1.51 \\
1.50 \\
1.73 \\
1.78 \\
1.99 \\
1.97\end{array}$ & $\begin{array}{l}18.7 \\
18.7 \\
19.4 \\
20.1 \\
20.9 \\
21.0 \\
21.5 \\
21.3 \\
22.5 \\
22.0\end{array}$ \\
\hline
\end{tabular}


II. PERFORMANCE DATA

\begin{tabular}{|c|c|c|c|c|c|c|c|}
\hline \multirow{5}{*}{$\begin{array}{r}\text { Data } \\
\text { Set } \\
\end{array}$} & \multicolumn{2}{|c|}{ Air Temperature } & \multicolumn{5}{|c|}{ Pressure } \\
\hline & & & & Relative & Pressure & Absolute & Pressure \\
\hline & Rotameter & Turbine & Gage & Rotameter & Turbine & Rotameter & Turbine \\
\hline & Inlet & Inlet & Zero & Inlet & Inlet & Inlet & Inlet \\
\hline & & & & & & & \\
\hline E10a. & & & -3.4 & & & & \\
\hline b.* & 73 & 73 & & 99.3 & .5 & 117.0 & 18.2 \\
\hline c. $\star$ & 73 & 73 & & 99.5 & .4 & 117.2 & 18.2 \\
\hline d.* & 73 & 73 & & 100.3 & .5 & 118.0 & 18.2 \\
\hline e.* & 73 & 73 & & 98.8 & .4 & 116.5 & 18.1 \\
\hline f. & 73 & 73 & & 93.8 & 6.2 & 111.5 & 23.9 \\
\hline g. & 73 & 73 & & 93.8 & 6.1 & 111.5 & 23.8 \\
\hline h. & 73 & 73 & & 94.2 & 6.1 & 111.9 & 23.8 \\
\hline$i$. & 72 & 72 & & 93.2 & 5.6 & 110.9 & 23.3 \\
\hline j. & 72 & 72 & & 89.0 & 15.1 & 106.7 & 32.8 \\
\hline k. & 72 & 72 & & 88.4 & 15.0 & 106.1 & 32.7 \\
\hline 1. & 72 & 72 & & 88.5 & 15.0 & 106.2 & 32.7 \\
\hline m. & 73 & 73 & & 89.4 & 15.2 & 107.1 & 32.9 \\
\hline n. & 72 & 72 & & 91.2 & 27.6 & 108.9 & 45.3 \\
\hline 0. & 73 & 73 & & 88.1 & 26.6 & 105.8 & 44.3 \\
\hline p. & 72 & 72 & & 90.2 & 28.0 & 107.9 & 45.7 \\
\hline q. & 72 & 72 & & 88.5 & 26.9 & 106.2 & 44.6 \\
\hline$r$. & 72 & 72 & & 86.7 & 33.6 & 104.4 & 51.3 \\
\hline s. & 72 & 72 & & 86.1 & 34.2 & 103.8 & 51.9 \\
\hline t. & 73 & 73 & & 88.7 & 36.2 & 106.4 & 53.9 \\
\hline u. & 72 & 72 & & 86.9 & 34.4 & 104.6 & 52.1 \\
\hline v. & 73 & 73 & & 85.8 & 46.5 & 103.5 & 64.2 \\
\hline w. & 72 & 72 & & 88.2 & 49.5 & 105.9 & 67.2 \\
\hline$x$. & 73 & 73 & & 84.1 & 46.8 & 101.8 & 64.0 \\
\hline$y$. & 73 & 73 & & 86.2 & 49.3 & 103.9 & 67.0 \\
\hline z. & 73 & 73 & & 86.1 & 56.3 & 103.8 & 74.0 \\
\hline aa. & 73 & 73 & & 87.1 & 58.2 & 104.8 & 75.9 \\
\hline $\mathrm{bb}$ & 73 & 73 & & 85.8 & 56.4 & 103.5 & 74.1 \\
\hline CC. & 73 & 73 & & 88.2 & 58.4 & 105.9 & 76.1 \\
\hline dd. & 73 & 73 & & 86.7 & 64.9 & 104.4 & 82.6 \\
\hline ee. & 73 & 73 & & 86.1 & 65.0 & 103.8 & 82.7 \\
\hline$f f$. & 73 & 73 & & 83.1 & 62.0 & 100.8 & 79.7 \\
\hline gg. & 73 & 73 & & 86.4 & 65.1 & 104.1 & 82.8 \\
\hline
\end{tabular}


II. PERFORMANCE DATA

\begin{tabular}{|c|c|c|c|c|c|c|c|}
\hline \multirow[b]{2}{*}{$\begin{array}{r}\text { Data } \\
\text { Set }\end{array}$} & \multicolumn{2}{|c|}{ Turbine Inlet Pressure } & \multicolumn{2}{|c|}{ Flow Rate } & \multicolumn{3}{|c|}{ Load Cell } \\
\hline & $\begin{array}{l}\text { Friction } \\
\text { Factor } \\
\end{array}$ & $\begin{array}{c}\text { Turbine } \\
\text { Pressure } \\
\text { (psia) }\end{array}$ & $\begin{array}{l}\text { Volume } \\
\left(\text { SCFM }_{0}\right)\end{array}$ & $\begin{array}{c}\text { Mass } \\
(1 \mathrm{bm} / \mathrm{sec})\end{array}$ & $\begin{array}{c}\text { Static } \\
\text { Zero } \\
\end{array}$ & $\begin{array}{c}\text { Excitation } \\
\text { Voltage } \\
(V D C) \\
\end{array}$ & $\begin{array}{c}\text { Output } \\
\text { Voltage } \\
\text { (mV) }\end{array}$ \\
\hline 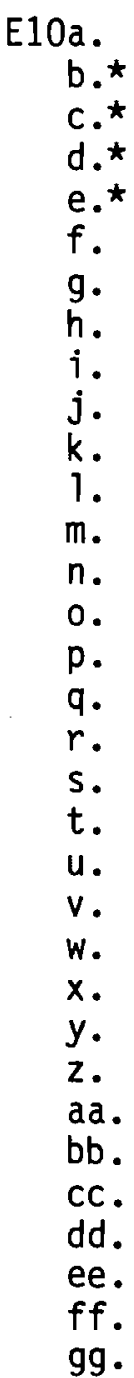 & $\begin{array}{l}.028 \\
.028 \\
.028 \\
.028 \\
.024 \\
.024 \\
.0236 \\
.0239 \\
.0211 \\
.0211 \\
.0211 \\
.0211 \\
.0191 \\
.0192 \\
.0192 \\
.0192 \\
.0182 \\
.0183 \\
.0183 \\
.0184 \\
.0172 \\
.0173 \\
.0172 \\
.0173 \\
.0165 \\
.0165 \\
.0165 \\
.0166 \\
.0161 \\
.0161 \\
.0163 \\
.0161\end{array}$ & $\begin{array}{l}17.8 \\
17.7 \\
17.8 \\
17.7 \\
22.9 \\
22.8 \\
22.8 \\
22.3 \\
31.0 \\
30.9 \\
30.9 \\
31.1 \\
42.5 \\
41.5 \\
43.0 \\
41.8 \\
47.7 \\
48.5 \\
50.6 \\
48.9 \\
59.8 \\
63.1 \\
59.5 \\
62.9 \\
68.8 \\
70.6 \\
68.9 \\
71.1 \\
76.9 \\
77.1 \\
74.2 \\
77.2\end{array}$ & $\begin{array}{l}0.9 \\
0.9 \\
0.9 \\
0.9 \\
1.55 \\
1.5 \\
1.55 \\
1.5 \\
2.4 \\
2.4 \\
2.4 \\
2.4 \\
3.4 \\
3.4 \\
3.4 \\
3.4 \\
4.2 \\
4.1 \\
4.1 \\
4.0 \\
5.2 \\
5.1 \\
5.3 \\
5.1 \\
6.1 \\
6.2 \\
6.1 \\
6.0 \\
6.7 \\
6.7 \\
6.6 \\
6.7\end{array}$ & $\begin{array}{l}.002 \\
.002 \\
.0025 \\
.0025 \\
.0046 \\
.0044 \\
.0046 \\
.0044 \\
.0073 \\
.0073 \\
.0073 \\
.0073 \\
.0107 \\
.0106 \\
.0107 \\
.0106 \\
.0131 \\
.0128 \\
.0129 \\
.0125 \\
.0163 \\
.0162 \\
.0165 \\
.0160 \\
.0192 \\
.0197 \\
.0192 \\
.0191 \\
.0213 \\
.0212 \\
.0206 \\
.0212\end{array}$ & .692 & $\begin{array}{l}8.46 \\
8.46 \\
8.46 \\
8.47 \\
8.47 \\
8.47 \\
8.47 \\
8.47 \\
8.47 \\
8.47 \\
8.47 \\
8.47 \\
8.47 \\
8.47 \\
8.47 \\
8.47 \\
8.47 \\
8.47 \\
8.47 \\
8.47 \\
8.47 \\
8.47 \\
8.47 \\
8.47 \\
8.47 \\
8.47 \\
8.47 \\
8.47 \\
8.47 \\
8.47 \\
8.47 \\
8.47 \\
8.47\end{array}$ & $\begin{array}{l}.635 \\
.630 \\
.635 \\
.630 \\
.690 \\
.680 \\
.690 \\
.690 \\
.785 \\
.785 \\
.790 \\
.795 \\
.960 \\
.940 \\
.950 \\
.950 \\
1.02 \\
1.01 \\
1.00 \\
1.02 \\
1.17 \\
1.19 \\
1.19 \\
1.22 \\
1.35 \\
1.37 \\
1.36 \\
1.34 \\
1.45 \\
1.46 \\
1.42 \\
1.47\end{array}$ \\
\hline
\end{tabular}


II . PERFORMANCE DATA

\begin{tabular}{|c|c|c|c|c|c|c|c|}
\hline \multirow[b]{2}{*}{$\begin{array}{r}\text { Data } \\
\text { Set }\end{array}$} & \multirow[b]{2}{*}{$\begin{array}{l}\text { Gross } \\
\text { Force } \\
\text { (1bf) } \\
\end{array}$} & \multirow[b]{2}{*}{$\begin{array}{c}\text { Net } \\
\text { Force } \\
\text { (1bf) }\end{array}$} & \multirow[b]{2}{*}{$\begin{array}{c}\text { Torque } \\
\text { (ft-lbf) }\end{array}$} & \multirow[b]{2}{*}{$\begin{array}{l}\text { Speed } \\
\text { (rpm) }\end{array}$} & \multicolumn{3}{|c|}{ Iuroine Pertormance } \\
\hline & & & & & $\begin{array}{l}\text { Power } \\
\text { Output } \\
\text { (hp) }\end{array}$ & $\begin{array}{r}\text { Input } \\
\text { (hp) }\end{array}$ & $\begin{array}{c}\text { Efficiency } \\
(\%) \\
\end{array}$ \\
\hline $\begin{array}{r}\text { E10a. } \\
\text { b. } \\
\text { c. } \\
\text { e. } \\
\text { f. } \\
\text { g. } \\
\text { h. } \\
\text { j. } \\
\text { k. } \\
1 . \\
\text { m. } \\
\text { n. } \\
\text { o. } \\
\text { q. } \\
r . \\
\text { s. } \\
\text { t. } \\
\text { u. } \\
\text { v. } \\
\text { w. } \\
\text { x. } \\
\text { y } \\
\text { z. } \\
\text { aa. } \\
\text { bb. } \\
c c . \\
\text { dd. } \\
\text { ee. } \\
\text { ff. } \\
\text { gg. }\end{array}$ & $\begin{array}{l}.125 \\
.124 \\
.125 \\
.124 \\
.136 \\
.134 \\
.136 \\
.136 \\
.155 \\
.155 \\
.155 \\
.156 \\
.189 \\
.185 \\
.187 \\
.187 \\
.201 \\
.199 \\
.197 \\
.201 \\
.230 \\
.234 \\
.234 \\
.240 \\
.266 \\
.270 \\
.268 \\
.264 \\
.285 \\
.287 \\
.279 \\
.289\end{array}$ & $\begin{array}{l}.010 \\
.009 \\
.010 \\
.009 \\
.021 \\
.019 \\
.021 \\
.021 \\
.039 \\
.039 \\
.040 \\
.041 \\
.074 \\
.070 \\
.072 \\
.072 \\
.086 \\
.084 \\
.082 \\
.086 \\
.115 \\
.119 \\
.119 \\
.125 \\
.151 \\
.155 \\
.153 \\
.149 \\
.170 \\
.172 \\
.164 \\
.174\end{array}$ & $\begin{array}{l}.005 \\
.004 \\
.005 \\
.004 \\
.010 \\
.009 \\
.010 \\
.010 \\
.019 \\
.019 \\
.019 \\
.019 \\
.035 \\
.033 \\
.034 \\
.034 \\
.041 \\
.040 \\
.039 \\
.041 \\
.055 \\
.056 \\
.056 \\
.059 \\
.072 \\
.074 \\
.073 \\
.071 \\
.081 \\
.082 \\
.078 \\
.083\end{array}$ & $\begin{array}{l}10000 \\
10000 \\
10000 \\
10000 \\
10000 \\
10000 \\
10000 \\
10000 \\
10000 \\
10000 \\
10000 \\
10000 \\
10000 \\
10000 \\
10000 \\
10000 \\
10000 \\
10000 \\
10000 \\
10000 \\
10000 \\
10000 \\
10000 \\
10000 \\
10000 \\
10000 \\
10000 \\
10000 \\
10000 \\
10000 \\
10000 \\
10000\end{array}$ & $\begin{array}{l}.009 \\
.008 \\
.009 \\
.008 \\
.019 \\
.017 \\
.019 \\
.019 \\
.035 \\
.035 \\
.036 \\
.037 \\
.067 \\
.063 \\
.065 \\
.065 \\
.078 \\
.076 \\
.074 \\
.078 \\
.104 \\
.108 \\
.108 \\
.113 \\
.136 \\
.140 \\
.138 \\
.135 \\
.154 \\
.155 \\
.148 \\
.157\end{array}$ & $\begin{array}{l}.026 \\
.025 \\
.027 \\
.026 \\
.104 \\
.099 \\
.103 \\
.095 \\
.259 \\
.257 \\
.259 \\
.262 \\
.519 \\
.500 \\
.520 \\
.504 \\
.690 \\
.679 \\
.705 \\
.667 \\
.990 \\
1.01 \\
1.00 \\
1.00 \\
1.25 \\
.963 \\
1.26 \\
1.27 \\
1.47 \\
1.46 \\
1.40 \\
1.47\end{array}$ & $\begin{array}{l}34.0 \\
31.4 \\
33.5 \\
31.1 \\
18.2 \\
17.1 \\
18.4 \\
20.0 \\
13.5 \\
13.6 \\
13.9 \\
14.1 \\
12.9 \\
12.6 \\
12.5 \\
12.9 \\
11.3 \\
11.2 \\
10.5 \\
11.7 \\
10.5 \\
10.7 \\
10.8 \\
11.3 \\
10.9 \\
10.8 \\
11.0 \\
10.6 \\
10.5 \\
10.6 \\
10.6 \\
10.7\end{array}$ \\
\hline
\end{tabular}


II. PERFORMANCE DATA

\begin{tabular}{|c|c|c|c|c|c|c|c|}
\hline \multirow[b]{2}{*}{$\begin{array}{r}\text { Data } \\
\text { Set } \\
\end{array}$} & \multicolumn{2}{|c|}{ Air Temperature } & \multicolumn{5}{|c|}{ Pressure } \\
\hline & $\begin{array}{c}\text { Rotameter } \\
\text { Inlet } \\
\left({ }^{\circ} \mathrm{F}\right) \\
\end{array}$ & $\begin{array}{l}\text { Turbine } \\
\text { Inlet } \\
\left({ }^{\circ} \mathrm{F}\right) \\
\end{array}$ & $\begin{array}{c}\text { Gage } \\
\text { Zero } \\
\text { (psig) }\end{array}$ & $\begin{array}{c}\text { Relative } \\
\text { Rotameter } \\
\text { Inlet } \\
\text { (psig) } \\
\end{array}$ & $\begin{array}{c}\text { Pressure } \\
\text { Turbine } \\
\text { Inlet } \\
\text { (psig) } \\
\end{array}$ & $\begin{array}{c}\text { Absolute } \\
\text { Rotameter } \\
\text { Inlet } \\
\text { (psia) }\end{array}$ & $\begin{array}{c}\text { Pressure } \\
\text { Turbine } \\
\text { Inlet } \\
\text { (psia) } \\
\end{array}$ \\
\hline 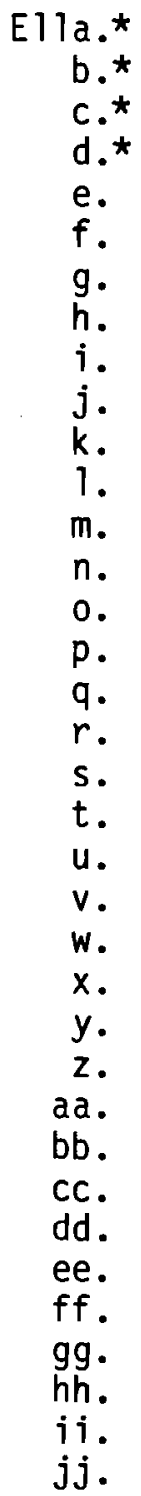 & $\begin{array}{l}73 \\
73 \\
73 \\
73 \\
73 \\
73 \\
73 \\
73 \\
73 \\
73 \\
73 \\
73 \\
73 \\
73 \\
73 \\
73 \\
73 \\
73 \\
73 \\
73 \\
73 \\
73 \\
73 \\
73 \\
74 \\
74 \\
74 \\
74 \\
74 \\
74 \\
74 \\
74 \\
75 \\
75 \\
75 \\
75\end{array}$ & $\begin{array}{l}73 \\
73 \\
73 \\
73 \\
73 \\
73 \\
73 \\
73 \\
73 \\
73 \\
73 \\
73 \\
73 \\
73 \\
73 \\
73 \\
73 \\
73 \\
73 \\
73 \\
73 \\
73 \\
73 \\
73 \\
74 \\
74 \\
74 \\
74 \\
74 \\
74 \\
74 \\
74 \\
75 \\
75 \\
75 \\
75\end{array}$ & & $\begin{array}{l}96.0 \\
96.0 \\
96.8 \\
96.0 \\
92.7 \\
93.2 \\
93.0 \\
91.5 \\
89.1 \\
91.8 \\
89.3 \\
87.4 \\
88.2 \\
90.0 \\
89.9 \\
88.3 \\
88.2 \\
89.5 \\
90.5 \\
86.6 \\
88.0 \\
85.6 \\
88.6 \\
86.2 \\
88.5 \\
84.3 \\
85.5 \\
89.2 \\
87.1 \\
83.9 \\
83.6 \\
86.0 \\
86.8 \\
86.4 \\
80.4 \\
82.2\end{array}$ & $\begin{array}{l}10.4 \\
10.2 \\
10.3 \\
10.2 \\
15.8 \\
15.8 \\
15.7 \\
15.4 \\
26.3 \\
27.7 \\
26.3 \\
25.8 \\
37.1 \\
38.1 \\
37.8 \\
37.1 \\
44.5 \\
47.5 \\
46.8 \\
45.0 \\
57.5 \\
54.7 \\
57.6 \\
54.6 \\
65.4 \\
63.6 \\
62.7 \\
65.7 \\
76.6 \\
73.3 \\
73.5 \\
75.6 \\
83.4 \\
83.0 \\
80.8 \\
81.2\end{array}$ & $\begin{array}{l}113.7 \\
113.7 \\
114.5 \\
113.7 \\
110.4 \\
110.9 \\
110.7 \\
109.2 \\
106.8 \\
109.5 \\
107.0 \\
105.1 \\
105.9 \\
107.7 \\
107.6 \\
106.0 \\
105.9 \\
107.2 \\
108.2 \\
104.3 \\
105.7 \\
103.3 \\
106.2 \\
103.9 \\
106.2 \\
102.0 \\
103.2 \\
106.9 \\
104.8 \\
101.6 \\
101.3 \\
103.7 \\
104.5 \\
104.1 \\
98.1 \\
99.9\end{array}$ & $\begin{array}{r}28.1 \\
27.9 \\
28.0 \\
27.9 \\
33.5 \\
33.5 \\
33.4 \\
33.1 \\
44.0 \\
45.4 \\
44.0 \\
43.5 \\
54.8 \\
55.8 \\
55.5 \\
54.8 \\
62.2 \\
65.2 \\
64.5 \\
62.7 \\
75.2 \\
72.4 \\
75.3 \\
72.3 \\
83.1 \\
81.3 \\
80.4 \\
83.4 \\
94.3 \\
91.0 \\
91.2 \\
93.3 \\
101.1 \\
100.7 \\
98.5 \\
98.9\end{array}$ \\
\hline
\end{tabular}


II. PERFORMANCE DATA

Turbine Inlet Pressure Corrected Inlet

Data Friction Pressure
Set Factor

\section{E}

a.* .0223

b.* .0223

c.* .0223

d.* .0223

e. .021

f. .021

g. .021

h. .021

i. $\quad .019$

j. .019

k. .019

l. .019

m. .018

n. .018

o. .018

p. .018

q. .017

r. .017

s. $\quad .017$

t. .017

u. .017

v. .017

w. .017

x. $\quad .017$

y. .016

z. $\quad .016$

aa. .016

bb. .016

cc. $\quad .016$

dd. $\quad .016$

ee. .016

ff. .016

gg. .015

hh. .015

ii. $\quad .016$

jj. $\quad .015$

Flow Rate

Folume

Volume Mass $\left(S C_{0 M}\right)(1 \mathrm{bm} / \mathrm{sec})$

26.7

26.5

26.6

26.5

31.6

31.6

31.2

31.2

41.2

42.6

41.2

40.7

51.4

52.4

52.1

51.4

57.9

61.1

60.3

58.5

70.5

67.4

70.5

67.3

77.5

75.7

76.6

77.8

88.1

84.4

84.8

86.7

94.5

93.9

91.8

92.1
$1.9 \quad .0058$

$1.9 \quad .0058$

$1.9 \quad .0059$

$1.9 \quad .0058$

$2.4 \quad .0074$

$2.4 \quad .0075$

$2.4 \quad .0074$

$2.4 \quad .0074$

$3.4 \quad .0106$

$\begin{array}{ll}3.4 & .0107\end{array}$

$3.4 \quad .0106$

$3.4 \quad .0105$

$4.2 \quad .0132$

$4.2 \quad .0133$

$4.2 \quad .0133$

$4.2 \quad .0132$

$5.0 \quad .0158$

$\begin{array}{ll}5.0 & .0159\end{array}$

$5.0 \quad .0160$

$\begin{array}{ll}5.0 & .0157\end{array}$

$\begin{array}{ll}5.8 & .0184\end{array}$

$5.9 \quad .0185$

$5.8 \quad .0185$

$5.9 \quad .0186$

$6.6 \quad .0211$
6.7

$6.7 \quad .0210$

$\begin{array}{ll}6.7 & .0211\end{array}$

$\begin{array}{ll}6.6 & .0212\end{array}$

$\begin{array}{ll}7.5 & .0239\end{array}$

$\begin{array}{ll}7.7 & .0242\end{array}$

$\begin{array}{ll}7.6 & .0238\end{array}$

$\begin{array}{ll}7.7 & .0244\end{array}$

$8.0 \quad .0255$

$8.1 \quad .0257$

$8.2 \quad .0253$

$8.2 \quad .0255$
Load Cell

Excitation Output Static Voltage Voltage Zero

( $\mathrm{DCC}$

(mV)

\subsection{7}

8.47

8.47

8.47

8.47

8.47

8.47

8.47

8.47

8.47

8.47

8.47

8.47

8.47

8.47

8.47

8.47

8.47

8.47

8.47

8.47

8.47

8.47

8.47

8.47

8.47

8.47

8.47

8.47

8.47

8.47

8.47

8.47

8.47

8.47

8.47
.640

.640

.640

.650

.690

.700

.700

.690

.810

.830

.810

.810

.940

.940

.950

.930

1.05

1.06

1.07

1.05

1.23

1.21

1.24

1.19

1.35

1.33

1.34

1.35

1.51

1.49

1.48

1.51

1.59

1.59

1.54

1.55 


\begin{tabular}{|c|c|c|c|c|c|c|c|}
\hline \multirow[b]{2}{*}{$\begin{array}{r}\text { Data } \\
\text { Set } \\
\end{array}$} & \multirow[b]{2}{*}{$\begin{array}{l}\text { Gross } \\
\text { Force } \\
\text { (1bf) } \\
\end{array}$} & \multirow[b]{2}{*}{$\begin{array}{c}\text { Net } \\
\text { Force } \\
\text { (1bf) }\end{array}$} & \multirow[b]{2}{*}{$\begin{array}{c}\text { Torque } \\
\text { (ft-1bf) }\end{array}$} & \multirow[b]{2}{*}{$\begin{array}{l}\text { Speed } \\
\text { (rpm) }\end{array}$} & \\
\hline & & & & & $\begin{array}{c}\text { Power } \\
\text { Output } \\
\text { (hp) }\end{array}$ & $\begin{array}{l}\text { Power } \\
\text { Input } \\
\text { (hp) }\end{array}$ & $\begin{array}{c}\text { Efficiency } \\
(\%)\end{array}$ \\
\hline 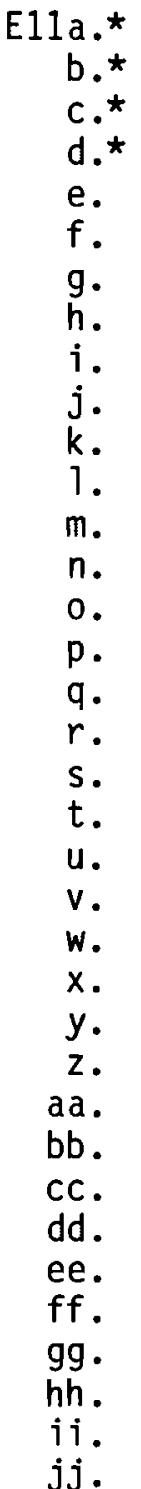 & $\begin{array}{l}.126 \\
.126 \\
.126 \\
.128 \\
.136 \\
.138 \\
.138 \\
.136 \\
.159 \\
.163 \\
.159 \\
.159 \\
.185 \\
.185 \\
.187 \\
.183 \\
.207 \\
.209 \\
.211 \\
.207 \\
.242 \\
.238 \\
.244 \\
.234 \\
.266 \\
.262 \\
.264 \\
.266 \\
.297 \\
.293 \\
.291 \\
.297 \\
.313 \\
.313 \\
.303 \\
.305\end{array}$ & $\begin{array}{l}.008 \\
.008 \\
.008 \\
.010 \\
.018 \\
.020 \\
.020 \\
.018 \\
.041 \\
.045 \\
.041 \\
.041 \\
.067 \\
.067 \\
.069 \\
.065 \\
.089 \\
.091 \\
.093 \\
.089 \\
.124 \\
.120 \\
.126 \\
.116 \\
.148 \\
.144 \\
.146 \\
.148 \\
.179 \\
.175 \\
.173 \\
.179 \\
.195 \\
.195 \\
.185 \\
.187\end{array}$ & $\begin{array}{l}.004 \\
.004 \\
.004 \\
.005 \\
.009 \\
.009 \\
.009 \\
.009 \\
.019 \\
.021 \\
.019 \\
.019 \\
.032 \\
.032 \\
.033 \\
.031 \\
.042 \\
.043 \\
.044 \\
.042 \\
.059 \\
.057 \\
.060 \\
.055 \\
.070 \\
.068 \\
.069 \\
.070 \\
.085 \\
.083 \\
.082 \\
.085 \\
.093 \\
.093 \\
.088 \\
.089\end{array}$ & $\begin{array}{l}20000 \\
20000 \\
20000 \\
20000 \\
20000 \\
20000 \\
20000 \\
20000 \\
20000 \\
20000 \\
20000 \\
20000 \\
20000 \\
20000 \\
20000 \\
20000 \\
20000 \\
20000 \\
20000 \\
20000 \\
20000 \\
20000 \\
20000 \\
20000 \\
20000 \\
20000 \\
20000 \\
20000 \\
20000 \\
20000 \\
20000 \\
20000 \\
20000 \\
20000 \\
20000 \\
20000\end{array}$ & $\begin{array}{l}.0145 \\
.0145 \\
.0145 \\
.0181 \\
.033 \\
.036 \\
.036 \\
.033 \\
.074 \\
.081 \\
.074 \\
.074 \\
.121 \\
.121 \\
.125 \\
.117 \\
.161 \\
.164 \\
.168 \\
.161 \\
.224 \\
.217 \\
.228 \\
.210 \\
.267 \\
.260 \\
.264 \\
.267 \\
.323 \\
.316 \\
.313 \\
.323 \\
.352 \\
.352 \\
.334 \\
.338\end{array}$ & $\begin{array}{l}.173 \\
.171 \\
.171 \\
.171 \\
.277 \\
.271 \\
.271 \\
.270 \\
.500 \\
.519 \\
.500 \\
.490 \\
.729 \\
.742 \\
.744 \\
.727 \\
.942 \\
.970 \\
.971 \\
1.00 \\
1.22 \\
1.20 \\
1.23 \\
1.20 \\
1.46 \\
1.44 \\
1.44 \\
1.47 \\
1.75 \\
1.74 \\
1.72 \\
1.78 \\
1.92 \\
1.93 \\
1.89 \\
1.91\end{array}$ & $\begin{array}{l}8.4 \\
8.5 \\
8.4 \\
10.6 \\
11.9 \\
13.3 \\
13.3 \\
12.2 \\
14.8 \\
15.6 \\
14.8 \\
15.1 \\
16.6 \\
16.3 \\
16.8 \\
16.1 \\
17.1 \\
16.9 \\
17.3 \\
16.1 \\
18.4 \\
18.1 \\
18.6 \\
17.5 \\
18.3 \\
18.1 \\
18.4 \\
18.2 \\
18.5 \\
18.2 \\
18.2 \\
18.2 \\
18.3 \\
18.3 \\
17.7 \\
17.7\end{array}$ \\
\hline
\end{tabular}


II. PERFORMANCE DATA

\begin{tabular}{|c|c|c|c|c|c|c|c|}
\hline \multirow[b]{2}{*}{$\begin{array}{c}\text { Data } \\
\text { Set } \\
\end{array}$} & \multicolumn{2}{|c|}{ Air Temperature } & \multicolumn{5}{|c|}{ Pressure } \\
\hline & $\begin{array}{l}\text { Rotameter } \\
\text { In let } \\
\text { (OF) } \\
\end{array}$ & $\begin{array}{l}\text { Turbine } \\
\text { Inlet } \\
\text { (OF) }\end{array}$ & $\begin{array}{l}\text { Gage } \\
\text { Zero } \\
\text { (psig) }\end{array}$ & $\begin{array}{c}\text { Relative } \\
\text { Rotameter } \\
\text { Inlet } \\
\text { (psig) } \\
\end{array}$ & $\begin{array}{c}\text { Pressure } \\
\text { Turbine } \\
\text { Inlet } \\
\text { (psig) } \\
\end{array}$ & $\begin{array}{c}\text { Absolute } \\
\text { Rotameter } \\
\text { Inlet } \\
\text { (psia) } \\
\end{array}$ & $\begin{array}{c}\text { Pressure } \\
\text { Turbine } \\
\text { Inlet } \\
\text { (psia) }\end{array}$ \\
\hline 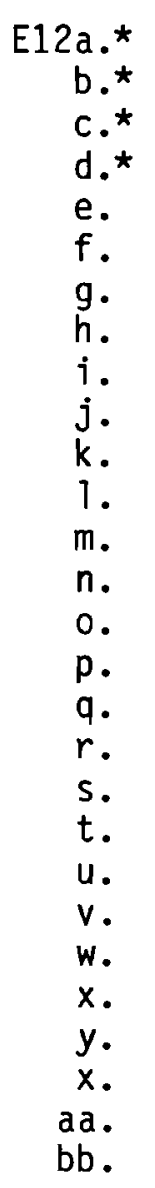 & $\begin{array}{l}74 \\
74 \\
74 \\
74 \\
74 \\
74 \\
74 \\
74 \\
74 \\
74 \\
74 \\
74 \\
74 \\
74 \\
74 \\
74 \\
74 \\
74 \\
74 \\
74 \\
74 \\
74 \\
74 \\
74 \\
74 \\
74 \\
74 \\
74\end{array}$ & $\begin{array}{l}74 \\
74 \\
74 \\
74 \\
74 \\
74 \\
74 \\
74 \\
74 \\
74 \\
74 \\
74 \\
74 \\
74 \\
74 \\
74 \\
74 \\
74 \\
74 \\
74 \\
74 \\
74 \\
74 \\
74 \\
74 \\
74 \\
74 \\
74\end{array}$ & & $\begin{array}{l}93.8 \\
95.3 \\
94.1 \\
95.6 \\
89.1 \\
88.9 \\
89.0 \\
91.1 \\
89.4 \\
88.5 \\
91.0 \\
90.8 \\
86.5 \\
90.7 \\
89.6 \\
87.1 \\
88.6 \\
87.6 \\
85.3 \\
84.8 \\
87.8 \\
83.7 \\
88.1 \\
83.6 \\
86.5 \\
84.9 \\
89.1 \\
89.1\end{array}$ & $\begin{array}{l}25.9 \\
26.1 \\
26.0 \\
26.3 \\
35.5 \\
35.6 \\
35.7 \\
37.5 \\
46.2 \\
46.1 \\
49.1 \\
48.9 \\
56.6 \\
57.7 \\
59.4 \\
58.0 \\
70.0 \\
69.5 \\
67.2 \\
66.8 \\
78.3 \\
75.5 \\
78.6 \\
75.7 \\
86.0 \\
82.0 \\
84.5 \\
84.4\end{array}$ & $\begin{array}{l}111.5 \\
113.0 \\
111.8 \\
113.3 \\
106.8 \\
106.6 \\
106.7 \\
108.8 \\
107.1 \\
106.2 \\
108.7 \\
108.5 \\
104.2 \\
108.4 \\
107.3 \\
104.8 \\
106.3 \\
105.3 \\
103.0 \\
102.5 \\
105.5 \\
101.4 \\
105.8 \\
101.3 \\
104.2 \\
102.6 \\
106.8 \\
106.8\end{array}$ & $\begin{array}{r}43.6 \\
43.8 \\
43.7 \\
44.0 \\
53.2 \\
53.3 \\
53.4 \\
55.2 \\
63.9 \\
63.8 \\
66.8 \\
66.6 \\
74.3 \\
75.4 \\
77.1 \\
75.7 \\
87.7 \\
87.2 \\
84.9 \\
84.5 \\
96.0 \\
93.2 \\
96.3 \\
93.4 \\
103.7 \\
99.7 \\
102.2 \\
102.1\end{array}$ \\
\hline $\begin{array}{c}\text { E13a.* } \\
\text { b.* } \\
\text { c.* } \\
\text { d.* } \\
\text { e. } \\
\text { f. } \\
\text { g. }\end{array}$ & $\begin{array}{l}74 \\
74 \\
74 \\
74 \\
74 \\
73\end{array}$ & $\begin{array}{l}74 \\
74 \\
74 \\
74 \\
74 \\
73\end{array}$ & & $\begin{array}{l}92.3 \\
89.5 \\
91.1 \\
89.9 \\
89.4 \\
88.9\end{array}$ & $\begin{array}{l}63.0 \\
62.0 \\
61.5 \\
59.3 \\
67.2 \\
67.0\end{array}$ & $\begin{array}{l}110.0 \\
107.2 \\
108.8 \\
107.6 \\
107.1 \\
106.6\end{array}$ & $\begin{array}{l}80.7 \\
79.7 \\
79.2 \\
77.0 \\
84.9 \\
84.7\end{array}$ \\
\hline
\end{tabular}


II. PERFORMANCE DATA

\begin{tabular}{|c|c|c|c|c|c|c|c|}
\hline \multirow[b]{2}{*}{$\begin{array}{r}\text { Data } \\
\text { Set }\end{array}$} & \multirow{2}{*}{\multicolumn{2}{|c|}{$\begin{array}{cc}\text { Turbine Inlet Pressure } & \begin{array}{c}\text { Corrected } \\
\text { Inlet }\end{array} \\
\text { Friction } & \text { Pressure } \\
\text { Factor } & \text { (psia) } \\
\end{array}$}} & \multicolumn{2}{|c|}{ Flow Rate } & \multicolumn{3}{|c|}{ Load Cell } \\
\hline & & & $\begin{array}{l}\text { Volume } \\
\left(\text { SCFM }_{0}\right)\end{array}$ & $\begin{array}{c}\text { Mass } \\
(1 \mathrm{bm} / \mathrm{sec})\end{array}$ & $\begin{array}{c}\text { Static } \\
\text { Zero } \\
\end{array}$ & $\begin{array}{c}\text { Excitation } \\
\text { Voltage } \\
(V D C) \\
\end{array}$ & $\begin{array}{c}\text { Output } \\
\text { Voltage } \\
\text { (mv) }\end{array}$ \\
\hline $\begin{array}{c}\text { E12a. } \\
\text { b. } \\
\text { c. } \\
\text { d. } \\
\text { e. } \\
\text { f. } \\
\text { g. } \\
\text { h. } \\
\text { i. } \\
\text { j. } \\
\text { k. } \\
\text { l. } \\
\text { m. } \\
\text { n. } \\
\text { o. } \\
\text { p. } \\
\text { q. } \\
\text { r. } \\
\text { s. } \\
\text { t. } \\
\text { u. } \\
\text { v. } \\
\text { w. } \\
\text { x. } \\
\text { y. } \\
\text { z. } \\
\text { aa. } \\
\text { bb. }\end{array}$ & $\begin{array}{l}.019 \\
.019 \\
.019 \\
.019 \\
.0183 \\
.0183 \\
.0183 \\
.0181 \\
.0172 \\
.0172 \\
.0172 \\
.0172 \\
.0166 \\
.0165 \\
.0166 \\
.0166 \\
.0161 \\
.0161 \\
.0161 \\
.0161 \\
.0156 \\
.0157 \\
.0157 \\
.0157 \\
.0153 \\
.0154 \\
.0153 \\
.0153\end{array}$ & $\begin{array}{l}41.0 \\
41.0 \\
41.1 \\
41.2 \\
49.8 \\
49.9 \\
50.0 \\
51.7 \\
59.3 \\
59.3 \\
62.5 \\
62.3 \\
69.2 \\
70.2 \\
72.1 \\
70.7 \\
82.3 \\
81.8 \\
79.3 \\
78.9 \\
89.7 \\
86.9 \\
90.1 \\
87.3 \\
97.0 \\
92.8 \\
95.4 \\
95.1\end{array}$ & $\begin{array}{l}3.2 \\
3.3 \\
3.2 \\
3.3 \\
4.1 \\
4.1 \\
4.1 \\
4.2 \\
5.2 \\
5.2 \\
5.1 \\
5.1 \\
6.0 \\
6.0 \\
6.0 \\
6.0 \\
6.7 \\
6.7 \\
6.8 \\
6.8 \\
7.6 \\
7.6 \\
7.5 \\
7.5 \\
8.2 \\
8.2 \\
8.1 \\
8.2\end{array}$ & $\begin{array}{l}.0102 \\
.0106 \\
.0102 \\
.0106 \\
.0129 \\
.0129 \\
.0129 \\
.0133 \\
.0166 \\
.0165 \\
.0164 \\
.0163 \\
.0189 \\
.0193 \\
.0192 \\
.0190 \\
.0214 \\
.0213 \\
.0214 \\
.0214 \\
.0243 \\
.0238 \\
.0240 \\
.0235 \\
.0261 \\
.0259 \\
.0261 \\
.0264\end{array}$ & & $\begin{array}{l}8.47 \\
8.47 \\
8.47 \\
8.47 \\
8.47 \\
8.47 \\
8.47 \\
8.47 \\
8.47 \\
8.47 \\
8.47 \\
8.47 \\
8.47 \\
8.47 \\
8.47 \\
8.47 \\
8.47 \\
8.47 \\
8.47 \\
8.47 \\
8.47 \\
8.47 \\
8.47 \\
8.47 \\
8.47 \\
8.47 \\
8.47 \\
8.47\end{array}$ & $\begin{array}{l}.770 \\
.780 \\
.770 \\
.760 \\
.860 \\
.870 \\
.860 \\
.880 \\
.990 \\
.980 \\
1.01 \\
1.00 \\
1.09 \\
1.09 \\
1.10 \\
1.09 \\
1.21 \\
1.18 \\
1.19 \\
1.18 \\
1.28 \\
1.27 \\
1.30 \\
1.27 \\
1.25 \\
1.25 \\
1.29 \\
1.32\end{array}$ \\
\hline $\begin{array}{c}\text { E13a.* } \\
\text { b.* } \\
\text { c.* } \\
\text { d.* } \\
\text { e. } \\
\text { f. } \\
\text { g. }\end{array}$ & $\begin{array}{l}.0163 \\
.0164 \\
.0164 \\
.0165 \\
.0161 \\
.0161\end{array}$ & $\begin{array}{l}75.3 \\
74.5 \\
74.1 \\
72.0 \\
79.2 \\
79.1\end{array}$ & $\begin{array}{l}6.3 \\
6.2 \\
6.1 \\
6.0 \\
6.7 \\
6.7\end{array}$ & $\begin{array}{l}.0205 \\
.0199 \\
.0197 \\
.0192 \\
.0215 \\
.0215\end{array}$ & .595 & $\begin{array}{l}8.47 \\
8.47 \\
8.47 \\
8.47 \\
8.47 \\
8.47 \\
8.47\end{array}$ & $\begin{array}{l}.930 \\
.910 \\
.900 \\
.900 \\
.930 \\
.930\end{array}$ \\
\hline
\end{tabular}


II. PERFORMANCE DATA

\begin{tabular}{|c|c|c|c|c|c|c|c|}
\hline \multirow[b]{2}{*}{$\begin{array}{r}\text { Data } \\
\text { Set } \\
\end{array}$} & \multirow[b]{2}{*}{$\begin{array}{l}\text { Gross } \\
\text { Force } \\
\text { (1bf) }\end{array}$} & \multirow[b]{2}{*}{$\begin{array}{c}\text { Net } \\
\text { Force } \\
\text { (1bf) } \\
\end{array}$} & \multirow[b]{2}{*}{$\begin{array}{c}\text { Torque } \\
\text { (ft-lbf) }\end{array}$} & \multirow[b]{2}{*}{$\begin{array}{l}\text { Speed } \\
\text { (rpm) }\end{array}$} & \multicolumn{3}{|c|}{ iuro ine rertormance } \\
\hline & & & & & $\begin{array}{c}\text { Power } \\
\text { Output } \\
\text { (hp) }\end{array}$ & $\begin{array}{l}\text { Power } \\
\text { Input } \\
\text { (hp) }\end{array}$ & $\begin{array}{c}\text { Efficiency } \\
(\%)\end{array}$ \\
\hline 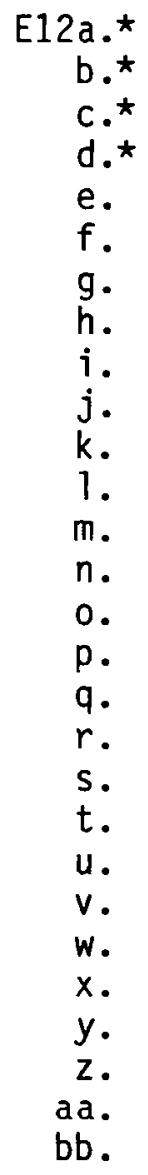 & $\begin{array}{l}.152 \\
.153 \\
.152 \\
.150 \\
.169 \\
.171 \\
.169 \\
.173 \\
.195 \\
.193 \\
.199 \\
.197 \\
.214 \\
.214 \\
.216 \\
.214 \\
.238 \\
.232 \\
.234 \\
.232 \\
.252 \\
.250 \\
.256 \\
.250 \\
.246 \\
.246 \\
.254 \\
.260\end{array}$ & $\begin{array}{l}.034 \\
.035 \\
.034 \\
.032 \\
.041 \\
.043 \\
.041 \\
.045 \\
.067 \\
.065 \\
.071 \\
.069 \\
.086 \\
.086 \\
.088 \\
.086 \\
.110 \\
.104 \\
.106 \\
.104 \\
.124 \\
.122 \\
.128 \\
.122 \\
.118 \\
.118 \\
.126 \\
.132\end{array}$ & $\begin{array}{l}.016 \\
.017 \\
.016 \\
.015 \\
.019 \\
.020 \\
.019 \\
.021 \\
.032 \\
.031 \\
.034 \\
.033 \\
.041 \\
.041 \\
.042 \\
.041 \\
.052 \\
.049 \\
.050 \\
.049 \\
.059 \\
.058 \\
.061 \\
.058 \\
.056 \\
.056 \\
.060 \\
.063\end{array}$ & $\begin{array}{l}30000 \\
30000 \\
30000 \\
30000 \\
30000 \\
30000 \\
30000 \\
30000 \\
30000 \\
30000 \\
30000 \\
30000 \\
30000 \\
30000 \\
30000 \\
30000 \\
30000 \\
30000 \\
30000 \\
30000 \\
30000 \\
30000 \\
30000 \\
30000 \\
30000 \\
30000 \\
30000 \\
30000\end{array}$ & $\begin{array}{l}.092 \\
.095 \\
.092 \\
.087 \\
.111 \\
.116 \\
.111 \\
.122 \\
.182 \\
.176 \\
.193 \\
.187 \\
.233 \\
.233 \\
.239 \\
.233 \\
.298 \\
.282 \\
.287 \\
.282 \\
.336 \\
.331 \\
.347 \\
.331 \\
.320 \\
.320 \\
.342 \\
.358\end{array}$ & $\begin{array}{l}.477 \\
.497 \\
.479 \\
.500 \\
.698 \\
.699 \\
.703 \\
.744 \\
1.01 \\
.994 \\
1.02 \\
1.02 \\
1.24 \\
1.27 \\
1.29 \\
1.26 \\
1.53 \\
1.52 \\
1.50 \\
1.49 \\
1.80 \\
1.74 \\
1.78 \\
1.72 \\
1.99 \\
1.94 \\
1.98 \\
2.00\end{array}$ & $\begin{array}{l}19.3 \\
19.1 \\
19.2 \\
17.4 \\
15.9 \\
16.6 \\
15.8 \\
16.4 \\
18.1 \\
17.7 \\
18.9 \\
18.4 \\
18.8 \\
18.3 \\
18.5 \\
18.5 \\
19.5 \\
18.6 \\
19.2 \\
18.9 \\
18.7 \\
19.0 \\
19.5 \\
19.3 \\
16.1 \\
16.5 \\
17.3 \\
17.9\end{array}$ \\
\hline $\begin{array}{c}\text { E13a.* } \\
\text { b.* } \\
\text { c.* } \\
\text { d.* } \\
\text { e. } \\
\text { f. }\end{array}$ & $\begin{array}{l}.183 \\
.179 \\
.177 \\
.177 \\
.183 \\
.183\end{array}$ & $\begin{array}{l}.059 \\
.055 \\
.053 \\
.053 \\
.059 \\
.059\end{array}$ & $\begin{array}{l}.028 \\
.026 \\
.025 \\
.025 \\
.028 \\
.028\end{array}$ & $\begin{array}{l}40000 \\
40000 \\
40000 \\
40000 \\
40000 \\
40000\end{array}$ & $\begin{array}{l}.213 \\
.199 \\
.192 \\
.192 \\
.213 \\
.213\end{array}$ & $\begin{array}{l}1.40 \\
1.35 \\
1.34 \\
1.29 \\
1.50 \\
1.50\end{array}$ & $\begin{array}{l}15.2 \\
14.7 \\
14.3 \\
14.9 \\
14.2 \\
14.2\end{array}$ \\
\hline
\end{tabular}


III. PREOPERATIONAL TEST - TURBINE ROTOR STATIONARY, INCREMENTAL LOAD TEST

Load Cel1

\begin{tabular}{|c|c|c|c|c|c|c|}
\hline $\begin{array}{r}\text { Data } \\
\text { Set }\end{array}$ & $\begin{array}{c}\text { Static } \\
\text { Zero } \\
(\mathrm{mV})\end{array}$ & $\begin{array}{c}\text { Excitation } \\
(V D C) \\
\end{array}$ & $\begin{array}{l}\text { Gross } \\
\text { Output } \\
(\mathrm{mV}) \\
\end{array}$ & $\begin{array}{c}\text { Net } \\
\text { Output } \\
(\mathrm{mV}) \\
\end{array}$ & $\begin{array}{c}\text { Measured } \\
\text { Load } \\
\text { (1bf) }\end{array}$ & $\begin{array}{l}\text { Approximate } \\
\text { Applied } \\
\text { Load } \\
\text { (1bf) }\end{array}$ \\
\hline $\begin{array}{l}\text { Ala. } \\
\text { b. } \\
\text { c. } \\
\text { d. }\end{array}$ & .620 & $\begin{array}{l}8.92 \\
8.92 \\
8.92 \\
8.90\end{array}$ & $\begin{array}{l}1.225 \\
1.487 \\
2.835\end{array}$ & $\begin{array}{l}.605 \\
.867 \\
2.215\end{array}$ & $\begin{array}{l}.113 \\
.148 \\
.415\end{array}$ & $\begin{array}{l}.101 \\
.162 \\
.367\end{array}$ \\
\hline $\begin{array}{r}\text { A2a. } \\
\text { b. } \\
\text { c. } \\
\text { d. } \\
\text { e. }\end{array}$ & .607 & $\begin{array}{l}8.43 \\
8.43 \\
8.43 \\
8.43 \\
8.44\end{array}$ & $\begin{array}{l}1.116 \\
1.389 \\
2.075 \\
3.134\end{array}$ & $\begin{array}{l}.509 \\
.782 \\
1.468 \\
2.527\end{array}$ & $\begin{array}{l}.101 \\
.155 \\
.290 \\
.499\end{array}$ & $\begin{array}{l}.101 \\
.148 \\
.249 \\
.467\end{array}$ \\
\hline $\begin{array}{l}\text { A3a. } \\
\text { b. } \\
\text { c. } \\
\text { d. }\end{array}$ & .548 & $\begin{array}{l}8.43 \\
8.43 \\
8.43 \\
8.43\end{array}$ & $\begin{array}{l}1.299 \\
1.754 \\
2.890\end{array}$ & $\begin{array}{l}.751 \\
1.206 \\
2.342\end{array}$ & $\begin{array}{l}.149 \\
.238 \\
.463\end{array}$ & $\begin{array}{l}.148 \\
.249 \\
.467\end{array}$ \\
\hline $\begin{array}{c}\text { A4a. } \\
\text { b. } \\
\text { c. } \\
\text { d. } \\
\text { e. } \\
\text { f. } \\
\text { g. } \\
\text { h. } \\
i . \\
\text { j. } \\
\text { k. } \\
\text { i. } \\
\text { m. } \\
\text { n. } \\
\text { o. } \\
\text { p. } \\
\text { q. }\end{array}$ & $\begin{array}{l}.550 \\
.536\end{array}$ & $\begin{array}{l}8.46 \\
8.46 \\
8.46 \\
8.46 \\
8.46 \\
8.46 \\
8.46 \\
8.46 \\
8.46 \\
8.46 \\
8.46 \\
8.46 \\
8.46 \\
8.46 \\
8.46 \\
8.46 \\
8.46\end{array}$ & $\begin{array}{l}.549 \\
.544 \\
.551 \\
.579 \\
.595 \\
.609 \\
.637 \\
.643 \\
.637 \\
.611 \\
.595 \\
.604 \\
.586 \\
.551 \\
.538\end{array}$ & $\begin{array}{l}.013 \\
.008 \\
.015 \\
.043 \\
.059 \\
.073 \\
.101 \\
.107 \\
.101 \\
.075 \\
.059 \\
.068 \\
.050 \\
.015 \\
.002\end{array}$ & $\begin{array}{l}.003 \\
.001 \\
.003 \\
.009 \\
.012 \\
.014 \\
.020 \\
.021 \\
.020 \\
.015 \\
.012 \\
.013 \\
.010 \\
.003 \\
.0004\end{array}$ & $\begin{array}{l}.003 \\
.006 \\
.009 \\
.012 \\
.015 \\
.019 \\
.022 \\
.025 \\
.022 \\
.019 \\
.015 \\
.012 \\
.009 \\
.006 \\
.003\end{array}$ \\
\hline
\end{tabular}


III. PREOPERATIONAL TEST - TURBINE ROTOR STATIONARY, INCREMENTAL LOAD TEST

\begin{tabular}{|c|c|c|c|c|c|c|}
\hline $\begin{array}{r}\text { Data } \\
\text { Set } \\
\end{array}$ & $\begin{array}{c}\text { Static } \\
\text { Zero } \\
(\mathrm{mV}) \\
\end{array}$ & $\begin{array}{c}\text { Excitation } \\
(V D C) \\
\end{array}$ & $\begin{array}{l}\text { Gross } \\
\text { Output } \\
\text { Voltage } \\
\text { (mV) } \\
\end{array}$ & $\begin{array}{c}\text { Measured } \\
\text { Load } \\
\text { (lbf) } \\
\end{array}$ & $\begin{array}{c}\text { Incremental } \\
\text { Change } \\
\text { (lbf) } \\
\end{array}$ & $\begin{array}{c}\text { Approximate } \\
\text { Applied } \\
\text { Incremental } \\
\text { Load } \\
\text { (lbf) } \\
\end{array}$ \\
\hline $\begin{array}{c}\text { A5a. } \\
\text { b. } \\
\text { c. } \\
\text { d. } \\
\text { e. } \\
\text { f. } \\
\text { g. } \\
\text { h. } \\
i . \\
\text { j. } \\
\text { k. } \\
\text { l. } \\
\text { m. } \\
\text { n. } \\
o . \\
\text { p. } \\
\text { q. } \\
r . \\
\text { s. } \\
\text { t. } \\
\text { u. } \\
\text { v. }\end{array}$ & .527 & $\begin{array}{l}8.46 \\
8.46 \\
8.46 \\
8.46 \\
8.46 \\
8.46 \\
8.46 \\
8.46 \\
8.46 \\
8.46 \\
8.46 \\
8.46 \\
8.46 \\
8.46 \\
8.46 \\
8.46 \\
8.46 \\
8.46 \\
8.46 \\
8.46 \\
8.46 \\
8.46\end{array}$ & $\begin{array}{l}.539 \\
.560 \\
.574 \\
.588 \\
.597 \\
.618 \\
.632 \\
.653 \\
.643 \\
.620 \\
.603 \\
.610 \\
.585 \\
.567 \\
.551\end{array}$ & $\begin{array}{l}.104 \\
.106 \\
.110 \\
.113 \\
.116 \\
.118 \\
.122 \\
.125 \\
.129 \\
.127 \\
.122 \\
.119 \\
.120 \\
.115 \\
.112 \\
.109 \\
.104 \\
.104 \\
.109 \\
.106 \\
.109 \\
.105\end{array}$ & $\begin{array}{r}.002 \\
.004 \\
.003 \\
.003 \\
.002 \\
.004 \\
.003 \\
.004 \\
-.002 \\
-.005 \\
-.003 \\
-.001 \\
-.005 \\
-.003 \\
-.003 \\
-.005 \\
0 \\
.005 \\
-.003 \\
.003 \\
-.004\end{array}$ & $\begin{array}{r}.003 \\
.003 \\
.003 \\
.003 \\
.003 \\
.003 \\
.003 \\
.003 \\
-.003 \\
-.003 \\
-.003 \\
-.003 \\
-.003 \\
-.003 \\
-.003 \\
-.003 \\
0 \\
.003 \\
-.003 \\
.003 \\
-.003\end{array}$ \\
\hline $\begin{array}{c}\text { A6a. } \\
\text { b. } \\
\text { c. } \\
\text { d. } \\
\text { e. } \\
\text { f. } \\
\text { g. } \\
\text { h. } \\
i . \\
\text { j. } \\
\text { k. } \\
\text { l. } \\
\text { m. } \\
\text { n. } \\
\text { o. } \\
\text { p. } \\
\text { q. }\end{array}$ & 1.635 & $\begin{array}{l}8.46 \\
8.46 \\
8.46 \\
8.46 \\
8.46 \\
8.46 \\
8.46 \\
8.46 \\
8.46 \\
8.46 \\
8.46 \\
8.46 \\
8.46 \\
8.46 \\
8.46 \\
8.46 \\
8.46\end{array}$ & $\begin{array}{l}1.650 \\
1.667 \\
1.684 \\
1.701 \\
1.714 \\
1.729 \\
1.742 \\
1.757 \\
1.740 \\
1.725 \\
1.710 \\
1.695 \\
1.678 \\
1.662 \\
1.646\end{array}$ & $\begin{array}{l}.322 \\
.325 \\
.328 \\
.332 \\
.335 \\
.338 \\
.341 \\
.343 \\
.346 \\
.343 \\
.340 \\
.337 \\
.334 \\
.331 \\
.327 \\
.324 \\
.321\end{array}$ & $\begin{array}{l}.003 \\
.003 \\
.004 \\
.003 \\
.003 \\
.003 \\
.002 \\
.003 \\
-.003 \\
-.003 \\
-.003 \\
-.003 \\
-.003 \\
-.004 \\
-.003 \\
-.003\end{array}$ & $\begin{array}{r}.003 \\
.003 \\
.003 \\
.003 \\
.003 \\
.003 \\
.003 \\
.003 \\
-.003 \\
-.003 \\
-.003 \\
-.003 \\
-.003 \\
-.003 \\
-.003 \\
-.003\end{array}$ \\
\hline
\end{tabular}


III. PREOPERATIONAL TEST - TURBINE ROTATING, INCREMENTAL LOAD TEST

\begin{tabular}{|c|c|c|c|c|c|c|}
\hline \multirow[b]{2}{*}{$\begin{array}{r}\text { Data } \\
\text { Set } \\
\end{array}$} & \multicolumn{3}{|c|}{ Turbine Pressure } & \multicolumn{2}{|c|}{$\begin{array}{l}\text { Load Cell } \\
\end{array}$} & \multirow[b]{2}{*}{$\begin{array}{c}\text { Gross } \\
\text { Output } \\
(\mathrm{mV}) \\
\end{array}$} \\
\hline & $\begin{array}{c}\text { Excitation } \\
(V D C) \\
\end{array}$ & $\begin{array}{c}\text { Transducel } \\
\text { Output } \\
\text { (V DC) } \\
\end{array}$ & $\begin{array}{c}\text { Net } \\
\text { Pressure } \\
\text { (psia) } \\
\end{array}$ & $\begin{array}{r}\text { Static } \\
\text { Zero } \\
(\mathrm{mv}) \\
\end{array}$ & $\begin{array}{l}\text { Excitation } \\
(V D C) \\
\end{array}$ & \\
\hline $\begin{array}{r}\text { A7a. } \\
\text { b. } \\
\text { c. } \\
\text { d. } \\
\text { e. } \\
\text { f. }\end{array}$ & $\begin{array}{l}12.5 \\
12.5 \\
12.5 \\
12.5 \\
12.5 \\
12.5\end{array}$ & 3.2 & 94.4 & .537 & $\begin{array}{l}8.46 \\
8.46 \\
8.46 \\
8.46 \\
8.46 \\
8.46\end{array}$ & $\begin{array}{l}.835 \\
.900 \\
.970 \\
.900 \\
.835\end{array}$ \\
\hline $\begin{array}{l}\text { A8a. } \\
\text { b. }\end{array}$ & $\begin{array}{l}12.5 \\
12.5\end{array}$ & 3.3 & 96.9 & 1.673 & $\begin{array}{l}8.47 \\
8.47\end{array}$ & 1.938 \\
\hline $\begin{array}{c}\text { A9a. } \\
\text { b. } \\
\text { c. } \\
\text { d. } \\
\text { e. } \\
\text { f. } \\
\text { g. } \\
\text { h. } \\
\text { i. } \\
\text { j. } \\
\text { k. } \\
\text { l. }\end{array}$ & $\begin{array}{l}12.5 \\
12.5 \\
12.5 \\
12.5 \\
12.5 \\
12.5 \\
12.5 \\
12.5 \\
12.5 \\
12.5 \\
12.5\end{array}$ & 1.18 & 43.9 & 1.527 & $\begin{array}{l}8.45 \\
8.46 \\
8.46 \\
8.46 \\
8.46 \\
8.46 \\
8.46 \\
8.46 \\
8.46 \\
8.46 \\
8.46 \\
8.46\end{array}$ & $\begin{array}{l}1.62 \\
1.93 \\
1.95 \\
1.97 \\
1.99 \\
2.02 \\
2.05 \\
2.02 \\
1.98 \\
1.95 \\
1.91\end{array}$ \\
\hline
\end{tabular}


III. PREOPERATIONAL TEST - TURBINE ROTATING, INCREMENTAL LOAD TEST

\begin{tabular}{|c|c|c|c|c|}
\hline $\begin{array}{r}\text { Data } \\
\text { Set }\end{array}$ & $\begin{array}{c}\text { Measured } \\
\text { Load } \\
\text { (1bf) } \\
\end{array}$ & $\begin{array}{c}\text { Incremental } \\
\text { Change } \\
(1 \mathrm{bf}) \\
\end{array}$ & $\begin{array}{c}\text { Applied } \\
\text { Incrementa } 1 \\
\text { Load } \\
\text { (1bf) } \\
\end{array}$ & $\begin{array}{l}\text { Speed } \\
\text { (rpm) }\end{array}$ \\
\hline $\begin{array}{l}\text { A7a. } \\
\text { b. } \\
\text { c. } \\
\text { d. } \\
\text { e. } \\
\text { f. }\end{array}$ & $\begin{array}{r}.164 \\
.177 \\
.191 \\
.177 \\
.164\end{array}$ & $\begin{array}{l}.013 \\
.014 \\
.014 \\
.013\end{array}$ & $\begin{array}{r}.012 \\
.012 \\
-.012 \\
-.012\end{array}$ & $\begin{array}{l}20000 \\
20000 \\
20000 \\
20000 \\
20000\end{array}$ \\
\hline $\begin{array}{r}A 8 a . \\
b .\end{array}$ & $\begin{array}{l}.381 \\
.381\end{array}$ & & & $\begin{array}{l}20000 \\
20000\end{array}$ \\
\hline $\begin{array}{c}\text { A9a. } \\
\text { b. } \\
\text { c. } \\
\text { d. } \\
\text { e. } \\
\text { f. } \\
\text { g. } \\
\text { h. } \\
i . \\
\text { j. } \\
\text { k. } \\
\text { l. }\end{array}$ & $\begin{array}{l}.319 \\
.380 \\
.384 \\
.388 \\
.392 \\
.398 \\
.404 \\
.398 \\
.390 \\
.384 \\
.376\end{array}$ & $\begin{array}{r}.004 \\
.004 \\
.004 \\
.004 \\
.006 \\
-.006 \\
-.008 \\
-.006 \\
-.008\end{array}$ & $\begin{array}{r}.006 \\
.003 \\
.003 \\
.006 \\
.006 \\
-.006 \\
-.006 \\
-.006 \\
-.006\end{array}$ & $\begin{array}{l}20000 \\
20000 \\
20000 \\
20000 \\
20000 \\
20000 \\
20000 \\
20000 \\
20000 \\
20000 \\
20000\end{array}$ \\
\hline
\end{tabular}


III. PREOPERATIONAL TEST - TURBINE ROTATING, INCREMENTAL LOAD TEST

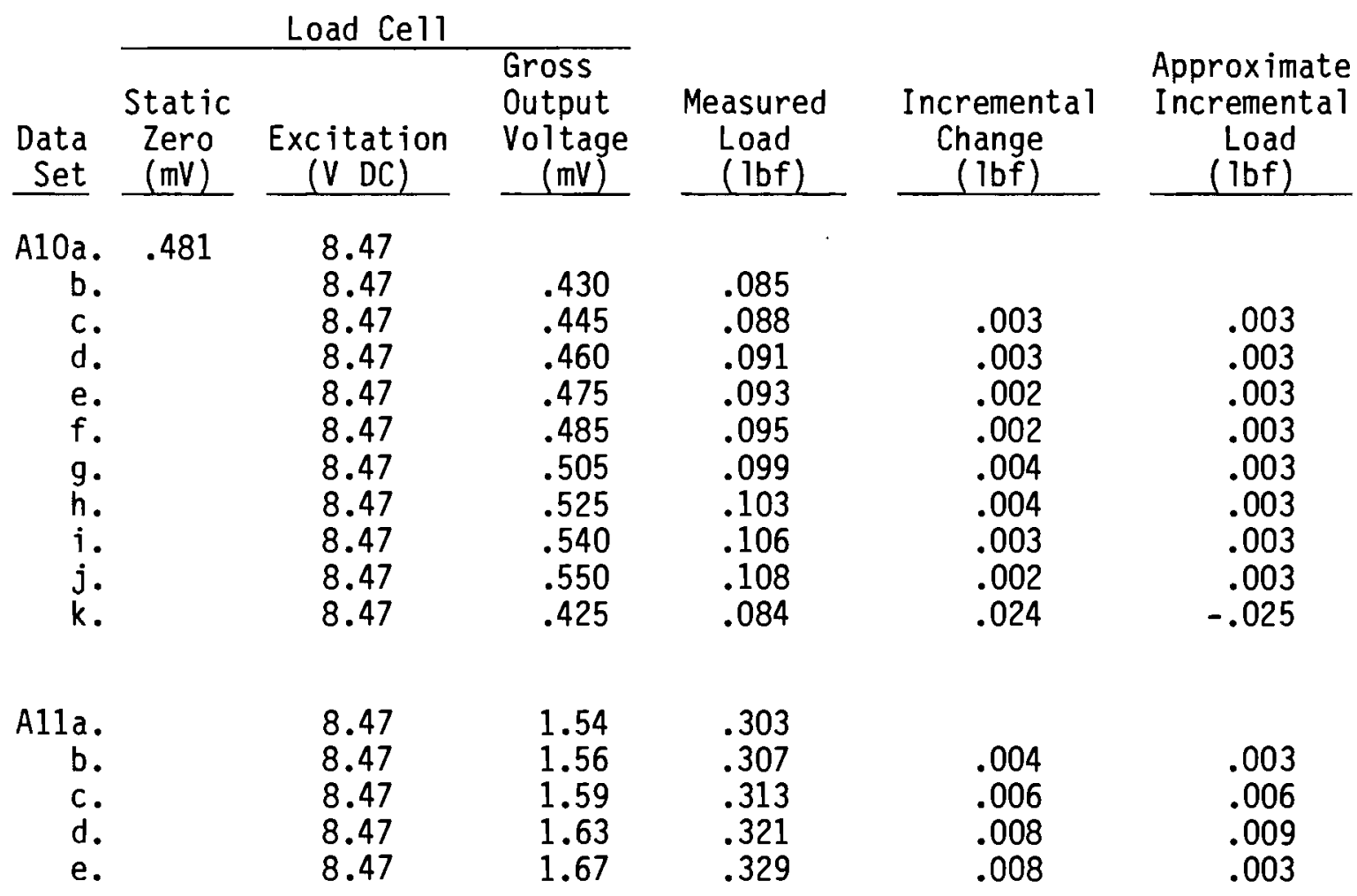


,

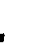




\section{APPENDIX D}

TURB INE EFFICIENCY UNCERTAINTY ANALYSIS 


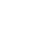




\section{APPENDIX D}

\section{TURBINE EFFICIENCY UNCERTAINTY ANALYSIS}

To provide an indication of the uncertainty of the turbine efficiency data presented in Appendix $C$ an uncertainty analysis based on a general method described by Schenck (1) was performed and is outlined herein.

Data uncertainty is commonly expressed in terms of a percent error which is based on an uncertainty interval, $w$, and the dependent variable value, $y$. Percent error is expressed as

$$
\% \text { Error }=\left(\frac{\omega y}{y}\right) \times 100 \%
$$

The uncertainty interval for a dependent variable which is a continuous and differentiable function of $n$ independent variables, $x_{n}$ is given by $(1)$

$$
\omega_{y}=\left\{\left(\frac{\partial y}{\partial x_{1}}\right)^{2} \omega_{x_{1}}^{2}+\left(\frac{\partial y}{\partial x_{2}}\right)^{2} \omega_{x_{2}}+\ldots+\left(\frac{\partial y}{\partial x_{n}}\right)^{2} \omega_{x_{n}}^{2}\right\}^{1 / 2} \text {. }
$$

The partial derivatives in Equation 0.2 are determined by first stating the functional dependence of $y$ on the independent variables $x_{n}$ and then performing the indicated differentiation. Uncertainty interval estimations originate in a variety of sources. For example, let $x_{1}$ represent the tachometer reading in rpm; $\omega_{x}$ may then be represented by a percentage of the ful1 scale deflection. ${ }^{1}$ Consider also the uncertainty interval of the load cell measurement, $x_{2} ; \omega_{x_{2}}$ may be represented by one-half the least significant digit of a steady voltmeter display reading or a percentage of the average of a fluctuating reading.

Turbine efficiency, $n$, is a function of inlet outlet pressures, $\mathrm{Pi}$ and Po; in let temperature, $\mathrm{Ti}$; mass flow rate, $\dot{\mathrm{m}}$; rotational speed, $\mathrm{N}$; force, $\mathrm{F}$; moment arm length, L. The functional dependence is given by

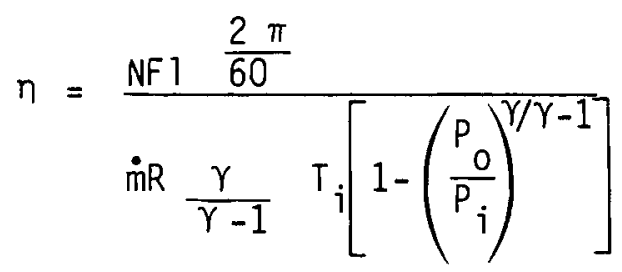


where $R$ is the gas constant and $\gamma$ is the ratio of specific heats.

Differentiating Equation D.3, assuming the turbine discharge pressure, $P_{0}$, to be invariant and arranging the terms as Equation D.2 yields:

$$
\begin{gathered}
\omega_{n}=\left\{\left(\frac{\partial \eta}{\partial N}\right)^{2} \omega_{N}^{2}+\left(\frac{\partial \eta}{\partial F}\right)^{2} \omega_{F}^{2}+\left(\frac{\partial \eta}{\partial T}\right)^{2} \omega_{1}^{2}+\right. \\
\left.\left(\frac{\partial \eta}{\partial \dot{m}}\right)^{2} \omega_{\dot{m}}^{2}+\left(\frac{\partial \eta}{\partial T_{i}}\right)^{2} \omega_{T_{i}}^{2}+\left(\frac{\partial \eta}{\partial P_{i}}\right)^{2} \omega_{P_{i}}^{2}\right\}^{1 / 2}
\end{gathered}
$$

The uncertainty intervals of speed, force, moment arm length, temperature and pressure are based on instrument readability and measurement fluctuation, Table D.1.

\begin{tabular}{|c|c|}
\hline Variable & Uncertainty Interval, \\
\hline Speed, N & $\begin{array}{l} \pm 0.5 \% \text { full scale value } \\
( \pm 200 \mathrm{rpm})\end{array}$ \\
\hline Force, $F$ & $\pm 10 \%$ data point \\
\hline $\begin{array}{l}\text { Moment arm } \\
\text { length, } 1\end{array}$ & $\begin{array}{l} \pm 0.005 \mathrm{in.}, \pm 4.17 \times \\
\left(10^{-4}\right) \mathrm{ft}\end{array}$ \\
\hline Temperature, $T_{\mathbf{i}}$ & $\pm 1^{\circ} \mathrm{F}, \pm 1^{\circ} \mathrm{R}$ \\
\hline Pressure, $P_{i}$ & $\begin{array}{l} \pm 5 \% \text { reading of pressure } \\
\text { transducer or } \\
\pm 0.2 \% \text { full scale value } \\
( \pm 4 \text { psig) of Heise gag }\end{array}$ \\
\hline
\end{tabular}

TABLE D.1. Uncertainty Intervals

Mass flow rate uncertainty interval is obtained by stating the functional dependence of mass flow rate on its appropriate independent variables and differentiating in accordance with Equation 0.2 as follows: 


$$
\begin{gathered}
\dot{m}=Q \frac{P_{r}}{R T_{r}} \\
\left.\omega_{\dot{m}}=\left(\frac{\partial \dot{m}}{\partial Q}\right)^{2} \omega_{Q}^{2}+\left(\frac{\partial \dot{m}}{\partial \bar{P}_{r}}\right)^{2} \omega_{P_{r}}^{2}+\left(\frac{\partial \dot{m}}{\partial T_{r}}\right)^{2} \omega_{T_{r}}^{2}\right\}^{1 / 2}
\end{gathered}
$$

where $Q$ is the volumetric flowrate.

The volume flow rate uncertainty interval is $0.05 \mathrm{ft}^{3} / \mathrm{min}$ and the uncertainty intervals of rotameter pressure and temperature are taken from Table 0.1 .

Results of a complete analys is of data point $E$ 10.f are summarized in Tables D.2, D 3, and D.4. The parameters of E10.f are among the lowest obtained during testing; hence the percentage errors tabulated are likely to be among the highest for the entire testing sequence.

\begin{tabular}{|c|c|}
\hline Parameter & Value \\
\hline $\begin{array}{l}\text { Temperatures } \\
\text { rotameter, } T_{r} \\
\quad \text { turbine in let, } T_{\mathbf{i}}\end{array}$ & $\begin{array}{l}533 R \\
533 R\end{array}$ \\
\hline $\begin{array}{l}\text { Pressures } \\
\text { rotameter, } \mathrm{P}_{\mathrm{P}} \\
\text { turbine inlet, } \mathrm{P}_{\mathrm{i}} \\
\text { discharge, } \mathrm{P}_{0}\end{array}$ & $\begin{array}{l}111.5 \text { psia } \\
22.9 \text { psia } \\
14.4 \text { psia }\end{array}$ \\
\hline $\begin{array}{l}\text { Volume flow rate, } Q \\
\text { (corrected to calibration) }\end{array}$ & $.491 \mathrm{cfm}$ \\
\hline Mass flow rate, $\dot{m}$ & $0.00461 \mathrm{bm} / \mathrm{sec}$ \\
\hline Speed, N & $10,000 \mathrm{rpm}$ \\
\hline Force, F & $0.021 \mathrm{lbf}$ \\
\hline Moment arm length, 1 & $0.475 \mathrm{ft}$ \\
\hline Efficiency, $n$ & .182 \\
\hline
\end{tabular}

TABLE D.2 Parameters of Data Point E10.f 
TABLE D.3. Summary of Mass Flow Rate Uncertainty Calculation for E10.f

\begin{tabular}{|c|c|c|c|}
\hline Parameter & Value & $\begin{array}{l}\text { Uncertainty } \\
\text { Interval, } \omega\end{array}$ & $\begin{array}{l}\text { Percent } \\
\text { Error, \% }\end{array}$ \\
\hline$Q$ & $.491 \mathrm{ft}^{3} / \mathrm{min}$ & $0.05 \mathrm{ft}^{3} / \mathrm{min}$ & 10.2 \\
\hline$T_{r}$ & $533 R$ & $1 \mathrm{R}$ & 0.2 \\
\hline$P_{r}$ & 111.5 psia & 4 psi & 3.6 \\
\hline$\dot{\mathrm{m}}$ & $0.0046 \mathrm{lbm} / \mathrm{sec}$ & $\begin{array}{l}4.99\left(10^{-4}\right) \\
1 \mathrm{bm} / \mathrm{sec}\end{array}$ & 10.8 \\
\hline
\end{tabular}

TABLE 0.4. Summary of Uncertainty Interval Calculations for Data Point E10.f

\begin{tabular}{|c|c|c|c|}
\hline Parameter & Value & $\begin{array}{l}\text { Uncertainty } \\
\text { Interval, } \omega\end{array}$ & $\begin{array}{l}\text { Percent } \\
\text { Error, \% }\end{array}$ \\
\hline N & $10,000 \mathrm{rpm}$ & 200 rpm & 2 \\
\hline $\mathrm{F}$ & $0.021 \mathrm{lbf}$ & $0.0021 \mathrm{lbf}$ & 10 \\
\hline 1 & $0.475 \mathrm{ft}$ & $4.17\left(10^{-4}\right) \mathrm{ft}$ & 0.09 \\
\hline$\dot{\mathrm{m}}$ & $0.00461 \mathrm{bm} / \mathrm{sec}$ & $\begin{array}{l}4.99\left(10^{-4}\right) \\
1 \mathrm{bm} / \mathrm{sec}\end{array}$ & 10.8 \\
\hline$T_{\mathbf{i}}$ & $533 \mathrm{R}$ & $1 \mathrm{R}$ & 0.2 \\
\hline$P_{i}$ & 22.9 psia & 4 psi & 17.5 \\
\hline$\eta$ & .182 & .0284 & 15.6 \\
\hline
\end{tabular}

\section{References}

1. Schenck, H. 1979. Theories of Engineering Experimentation. Third Edition. Hemisphere Publishing Corporation, Washington, D.C. 


\section{$\underline{\text { DISTRIBUTION }}$}

No. of

Copies

OFFSITE

2 J. Gamill

1220 East W. Highway

Blair East Apt. \#902

Silver Spring, MD 20910

5 Office of Industrial Programs

Forrestal Building

1000 Independence Avenue, S.W.

Washington, D.C. 20585

27 DOE Technical Information Center
No. of

Copies

ONSITE

DOE Richland Operations Office

H. E. Ransom

16 Pacific Northwest Laboratory

J. S. Barnhart

C. H. Bloomster

D. E. Deonigi

E. J. Eschbach

B. A. Garrett-Price

S. G. Hauser

W. W. Laity

N. L. Moore

L. D. Williams

Technical Information Files (5)

Publishing Coordination (2) 

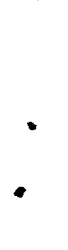